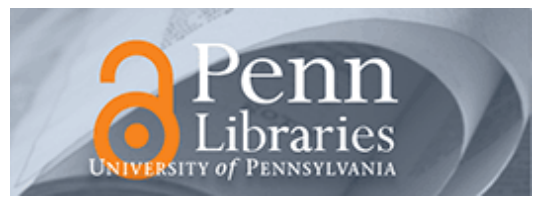

University of Pennsylvania

ScholarlyCommons

Marketing Papers

Wharton Faculty Research

3-2018

Does Ease Mediate the Ease-of-Retrieval Effect? A Meta-Analysis

Evan Weingarten

University of Pennsylvania

J. W. Hutchinson

University of Pennsylvania

Follow this and additional works at: https://repository.upenn.edu/marketing_papers

Part of the Applied Behavior Analysis Commons, Behavioral Economics Commons, Cognition and Perception Commons, Cognitive Psychology Commons, and the Marketing Commons

Recommended Citation

Weingarten, E., \& Hutchinson, J. W. (2018). Does Ease Mediate the Ease-of-Retrieval Effect? A Meta-

Analysis. Psychological Bulletin, 144 (3), 227-283. http://dx.doi.org/10.1037/bul0000122

This paper is posted at ScholarlyCommons. https://repository.upenn.edu/marketing_papers/382

For more information, please contact repository@pobox.upenn.edu. 


\title{
Does Ease Mediate the Ease-of-Retrieval Effect? A Meta-Analysis
}

\author{
Abstract \\ A wealth of literature suggests individuals use feelings in addition to facts as sources of information for \\ judgment. This paper focuses on a manipulation in which participants list either a few or many examples \\ of a given type, and then make a judgment. Instead of using the number of arguments or evidence \\ strength, participants are hypothesized to use the subjective ease of generating examples as the primary \\ input to judgment. This result is commonly called the ease-of-retrieval effect, and the feeling of ease is \\ typically assumed to mediate the effect. We use meta-analytic methods across 142 papers, 263 studies, \\ and 582 effect sizes to assess the robustness of the ease-of-retrieval effect, and whether or not the effect \\ is mediated by subjective ease. On average, the standard few/many manipulation exhibits a medium- \\ sized effect. In experimental conditions designed to replicate the standard effect, about one third to one \\ half of the total effect is mediated by subjective ease. This supports the standard explanation, but \\ suggests that other mediators are present. Further, we find evidence of publication bias that reduces the \\ standard effect by up to one-third. We also find that (1) moderator manipulations that differ from the \\ standard manipulation lead to smaller, often reversed effects that are not as strongly mediated as ease, \\ (2) several manipulations of theory-based moderators (e.g., polarized attitudes, misattribution) yield \\ strong theory-consistent effects, (2) method-based moderators have little or no effects on the results, and \\ (4) the mediation results are robust with respect to assumptions about error structure.

\section{Disciplines} \\ Applied Behavior Analysis | Behavioral Economics | Business | Cognition and Perception | Cognitive \\ Psychology | Marketing
}


Does Ease Mediate the Ease-of-Retrieval Effect? A Meta-Analysis 


\begin{abstract}
A wealth of literature suggests individuals use feelings in addition to facts as sources of information for judgment. This paper focuses on a manipulation in which participants list either a few or many examples of a given type, and then make a judgment. Instead of using the number of arguments or evidence strength, participants are hypothesized to use the subjective ease of generating examples as the primary input to judgment. This result is commonly called the easeof-retrieval effect, and the feeling of ease is typically assumed to mediate the effect. We use meta-analytic methods across 142 papers, 263 studies, and 582 effect sizes to assess the robustness of the ease-of-retrieval effect, and whether or not the effect is mediated by subjective ease. On average, the standard few/many manipulation exhibits a medium-sized effect. In experimental conditions designed to replicate the standard effect, about one third to one half of the total effect is mediated by subjective ease. This supports the standard explanation, but suggests that other mediators are present. Further, we find evidence of publication bias that reduces the standard effect by up to one-third. We also find that (1) moderator manipulations that differ from the standard manipulation lead to smaller, often reversed effects that are not as strongly mediated by ease, (2) several manipulations of theory-based moderators (e.g., polarized attitudes, misattribution) yield strong theory-consistent effects, (3) method-based moderators have little or no effects on the results, and (4) the mediation results are robust with respect to assumptions about error structure.
\end{abstract}

Public Significance Statement: This quantitative review suggests a medium-sized impact of feelings of ease of recall on judgment, but it argues feelings of ease alone may not fully explain classical inductions of feeling-based effects. This review also reports several moderators of when individuals use their feelings in judgment. 


\section{Does Ease Mediate the Ease-of-Retrieval Effect? A Meta-Analysis}

A man's wife asks him, "Do remember the day we first met?" He immediately answers, "Of course." She then asks, "What was I wearing?" He replies, "Tight fitting jeans, a black sweater, black Nike running shoes, and a weirdly huge leather jacket." She smiles. He smiles.

It is not surprising that the wife believes that her husband's excellent memory is evidence of his love. What is surprising is the conjecture that his quick, easy memory strengthens the husband's own belief about the depth of his love for his wife. That is, in addition to the facts that are recalled, the conjecture claims that the experience of remembering, the feeling of ease, is itself treated as information that can influence our judgments. This conjecture is called the easeof-retrieval effect, and there is a large literature devoted to it. This paper is a meta-analysis of that large literature and aims to answer the question, "Does ease mediate the ease-of-retrieval effect?"

\section{Introduction}

Decades of research in psychology and economics have challenged "rational" theories of human decision-making (Einhorn \& Hogarth, 1981; Johnson \& Payne, 1985; Kahneman \& Tversky, 1979; Simon, 1978). Critically, individuals do not always base their decisions on the weight of evidence pro and con, but often use other cues and heuristics that are not relevant from a normative perspective (Albarracin, Johnson, \& Zanna, 2005; Bettman et al., 1998; Chaiken, Liberman, \& Eagly, 1989; Gigerenzer \& Selten, 2002; Schwarz \& Clore, 1983; Tversky \& Kahneman, 1974). One famous example is the availability heuristic. According to the availability heuristic, individuals make judgments based on how easy it feels to bring examples to mind rather than based on the strength of those examples (Tversky \& Kahneman, 1973). 
One very general perspective accounts for many of the non-normative findings by hypothesizing that feelings are often mixed in with facts as decision inputs (Greifeneder, Bless, \& Pham, 2011; Pham, 1998; Schwarz, 2010; Schwarz \& Clore, 1983, 1988, 2007). These feelings include both affective feelings (i.e., experiences of moods or emotions, such as happiness; Pham, 2004) and cognitive feelings (i.e., experiences of mental activities, metacognition, such as feelings of ease; Greifeneder, Bless, \& Pham, 2011; Schwarz, 2010; Schwarz \& Clore, 2007). For example, the availability heuristic is hypothesized to result from the use of feelings of ease as an input to judgment (Schwarz \& Clore, 1983, 1988, 2007).

Cognitive feelings are typically divided into two major forms: processing fluency and accessibility experiences (Schwarz \& Clore, 2007). Processing fluency is the subjective ease with which information is encoded, and accessibility experiences are the feelings of the ease with which information is retrieved from memory (Alter \& Oppenheimer, 2009; Schwarz \& Clore, 2007). This paper focuses on the specific hypothesis that accessibility experiences are part of a meta-cognitive process that affects judgment (Schwarz, 2010; Schwarz \& Clore, 2007). This meta-cognitive role is very similar to the role of feelings of familiarity in the recognition memory literature (Jacoby \& Dallas, 1981; Jacoby, Kelley, \& Dywan, 1989; Johnston, Dark, \& Jacoby, 1985).

One seminal demonstration of the effects of accessibility experiences is Schwarz et al. (1991), in which individuals first generated examples of being assertive and then rated their assertiveness on a multi-item scale. The critical manipulation was whether the experimenters requested participants to write few (6) or many (12) examples (i.e., a few-versus-many manipulation). The critical result was that self-rated assertiveness was lower in the "many" condition than in the "few" condition. Schwarz et al. contended that, although those in the 
"many" condition had more evidence to support high assertiveness than those in the "few" condition, they rated themselves lower because they inferred low assertiveness from the difficulty they experienced in the example-generation task. This type of metacognitive inference has become the standard explanation of the effects of the few-versus-many manipulation and, therefore, such effects are commonly called ease-of-retrieval effects. Importantly, the ease-ofretrieval effect is the opposite of what is predicted by content numerosity (i.e., people using number of examples, which they have more of in the "many" condition; Pelham, Smurata, \& Myaskovsky, 1994) and polarization (i.e., attitudes becoming more extreme with more information; Lord, Ross, \& Lepper, 1979).

Metacognitive inferences based on subjective ease have also been proposed as explanations for the effects of the few-versus-many manipulation on judgments about traits, attitudes, likelihoods, and preferences. For example, this manipulation has been used in studies of health (by influencing perceived vulnerability; Raghubir \& Menon, 1998), consumer preference (by tilting preference for compromise options; Novemsky et al., 2007), and policy and political figure attitudes (by affecting support for them; Haddock, 2002; Wänke, Bless, \& Biller, 1996). Moreover, this manipulation has been used in experiments examining a wide variety of tasks, such as product choice (Zhao et al., 2012), cooperation (Müller et al., 2010), and prediction (Pham, Lee, \& Stephen, 2012). One indicator of the influence of both the manipulation and the ease-of-retrieval explanation is that the original Schwarz et al. (1991) paper has 577 citations on Web of Science and 1224 on Google Scholar as of July 2017.

Although subjective ease is the dominant explanation, other accounts of the ease-ofretrieval effect have been proposed. First, individuals in the "many" condition might spontaneously think of more conflicting examples than individuals in the "few" condition, which 
would yield directionally-similar effects as ease (Tormala et al., 2007; but see Wänke et al., 1996; Wänke, 2013). Second, Kühnen (2010) proposed that placing the ease question before the dependent measure in studies creates a demand effects that explains the results. Finally, ease might increase confidence in what is generated. Subsequently, confidence may then influence judgments and attitudes (Wänke \& Bless, 2000; Tormala et al., 2002). According to these accounts, subjective ease is not the only or the most immediate mediator of the observed effects.

The existence of these alternative explanations and causal paths increases the desirability of determining the extent to which subjective ease, by itself, mediates the ease-of-retrieval effect. If ease does not fully explain the effect (i.e., a mediation analysis reveals a residual direct effect that is comparable in size to the indirect effect based on subjective ease), then the alternative explanations are potentially necessary for a full account of the phenomenon.

This paper reports a meta-analysis of the ease-of-retrieval effect and is designed (a) to test the robustness of the effect, (b) to examine the extent to which subjective ease of retrieval mediates the effect, (c) to find evidence for or against several theoretical accounts of the effect, and (d) to determine if methodological factors might account for variation in effect sizes. Our analyses provide five main results. First, we find a medium effect size estimate for experimental conditions that were designed to conceptually replicate the original ease-of-retrieval effect, which we call the standard paradigm. Second, we find that accounting for publication bias could potentially reduce the standard paradigm's effect size by approximately a third. Third, we find support for several theory-based moderators of the effect. Fourth, we find little support for several potential artifacts that have been proposed in the literature or for methodological moderators other than publication status. Fifth, we find that subjective ease is a robust partial mediator for proximal dependent measures in the standard paradigm, but that the direct effect is 
equally robust, suggesting that other mediators are present, even under "ideal" conditions. Also, reasonable assumptions about heterogeneity, measurement error, and correlated error lead to smaller estimates of the indirect effect and larger estimates of the direct effect, again suggesting that other mediators are present.

\section{Theory-Based and Methodological Moderators of the Ease-of-Retrieval Effect}

One important goal of this meta-analysis is to examine a wide range of theory-based moderators that have been proposed in the feelings-as-information literature. These moderators provide potential explanations of heterogeneity in effect sizes. We divide these moderators into those that potentially inform theories of judgment (e.g., misattribution and involvement) and those that are mainly exploratory or methodological (e.g., the country in which data were collected).

It is useful to subdivide theory-based moderators according to how they influence the use of subjective ease. First, there are moderators that affect the experience of ease or its accessibility. We call these moderators salience-based. Second, there are moderators that influence the relationship between the manipulation and the dependent measure by changing either the weighting of ease as an informational input or the weighting of other non-feeling inputs in the judgment process. We call these moderators inference-based. The impact of these two classes of moderators can be seen in Figure 1. By making subjective ease more salient, salience moderators might change the effect of the manipulation $\left(S_{1}\right.$ in Figure 1$)$, or they might change the effect of subjective ease on the dependent measure by changing the accessibility of this input $\left(\mathrm{S}_{2}\right)$. Inference-based moderators might also change the effect of ease on the dependent measure $\left(\mathrm{I}_{2}\right)$, not by changing the accessibility of ease, but by changing the implications people 
draw from this cognitive feeling. Additionally, inference-based moderators might trigger some other non-ease mechanism $\left(\mathrm{I}_{1}\right)$.

We drew upon a series of reviews within the ease-of-retrieval and feelings-as-information literatures to identify a set of salience and inference moderators. These reviews included Greifeneder, Bless, and Pham (2011), Petty et al. (2007), Schwarz (1998, 2004), Schwarz and Clore (1988, 2007), and Wänke (2013). Our meta-analysis builds on these reviews by systematically coding the ease-of-retrieval studies in our database in terms of these moderators and then quantitatively testing the extent to which those moderators are associated with differences in effect size.

While some moderators apply to the whole study (e.g., type of dependent measure, publication status), other moderators exist only for some conditions within a study (e.g., misattribution used or not; polarized attitude or not). Therefore, for each paper, we split up the experiment by moderator level into a few-versus-many effect size for each level of the moderator.

\section{Salience Moderators}

Salience moderators are those that affect the retrievability of content or the experience of ease. These salience moderators should therefore exert an influence through an impact of the manipulation on experienced ease $\left(\mathrm{S}_{1}\right)$ or the impact of ease on the dependent measure $\left(\mathrm{S}_{2}\right)$.

Range. Feelings of subjective ease are likely to become more salient when the retrieval task is either much easier or much more difficult than usual. As the difference increases between the number of items required for the "few" and "many" conditions, it is more likely that one or both will be far from the usual level of retrieval ease. We operationalize this moderator as range 
(i.e., "many" target number - "few" target number). This metric should be positively related to the size of the effect, as it should affect ease and the downstream impact of the manipulation.

Attention. The salience of cognitive feelings should be enhanced when attention is explicitly directed toward those feelings. Many ease-of-retrieval experiments include an explicit measure of feelings of ease. When the feelings of ease are explicitly measured before (rather than after) the target judgment, attention is drawn to cognitive feelings, which makes them more salient during the target judgment (Danziger et al., 2005; Kühnen, 2010). This should lead to larger effect sizes.

Polarized attitude. Individuals with either polarized or crystallized attitudes are less likely to experience difficulty in generating examples $\left(S_{1}\right)$, which should decrease the impact of the few-versus-many manipulation and thereby decrease effect sizes (e.g., Dijksterhuis et al., 1999; Haddock, 2002; Haddock et al., 1999). However, it is also possible that those with polarized attitudes make fewer meta-cognitive inference based on ease $\left(I_{2}\right)$ or rely on other information or inferences $\left(\mathrm{I}_{1}\right)$.

\section{Inference Moderators}

These moderators include those manipulations within experiments or differences across experiments that affect the perceived meaning of feelings of ease $\left(\mathrm{I}_{2}\right)$ or introduce considerations of other possible cues to judgment that run contrary to the predictions of ease as an input or increase the direct effect of the few-versus-many manipulation $\left(\mathrm{I}_{1}\right)$.

Processing motivation (depth). The first set of moderators concerns processing motivation, meaning the extent to which an individual is willing to deeply consider the scenario or judgment in question (Chaiken et al., 1989; Greifeneder, Bless, \& Pham, 2011; Petty et al., 
2007; Schwarz, 2004). We distinguish two types of processing motivation: depth and involvement.

Depth of processing factors found in the ease-of-retrieval literature include accuracy motivation (i.e., no ease effect for high accuracy motivation; Aarts \& Dijksterhuis, 1999), availability of cognitive processing resources (i.e., ease effects stronger for those under cognitive constraint; Greifeneder \& Bless, 2007), and whether people are in positive or negative moods (Ruder \& Bless, 2003), the latter of which should lead to greater systematic processing (lower effect sizes; also see Tiedens \& Linton, 2001). Consistent with this logic, Ruder and Bless (2003) find a reversed ease-of-retrieval effect for participants induced to feel sad.

Processing motivation (involvement). The most prominent type of motivation factor in the ease-of-retrieval literature is whether people engage in low involvement or heuristic (i.e., individuals process few pieces of information with less effort) versus high involvement systematic (i.e., individuals analytically evaluate much more information carefully; Chaiken et al., 1989) processing. The ease-of-retrieval effect was originally specified in terms of the heuristic-systematic model and hypothesized to reflect a heuristic (low elaboration) strategy for individuals for whom the target judgment has low personal relevance (Chaiken et al., 1989; Petty \& Cacioppo, 1984). Two initial articles found that individuals with higher personal relevance (which presumably increased systematic processing) in a topic reversed the predictions of easeof-retrieval, while individuals with lower personal relevance (which presumably increased heuristic processing) produced results consistent with ease-of-retrieval (Grayson \& Schwarz, 1999; Rothman \& Schwarz, 1998). However, Tormala et al. (2002) provides another account of how involvement should affect the use of feelings of ease. In this view, individuals who elaborate more should pay attention to their higher-order thoughts and thus incorporate ease into 
their judgments (Hirt, Kardes, \& Markman, 2004; Petrocelli \& Dowd, 2009; Petty et al., 2007; Tormala et al., 2002). Thus, these authors hypothesize that their manipulation of processing motivation should have effects opposite to those of the previously mentioned authors (i.e., the ease-of-retrieval effect should be enhanced). Although the manipulations of involvement are not identical across studies, they are conceptually focused on personal relevance and the difference in predictions arises from assumptions about how personal relevance affects the likelihood of systematic processing. Thus, the meta-analytic results for this moderator are potentially informative about the relationship between cognitive feelings and systematic processing.

Representativeness (retrieval target). Individuals should be more likely to apply feelings to target judgments when their feelings are believed to be more representative of the target of the retrieval task (e.g., your own assertiveness; Schwarz et al., 1991; Greifeneder et al., 2011). For example, individuals are more likely to display an ease-of-retrieval effect when making judgments about themselves as opposed to others (e.g., Caruso, 2008) because their feelings are more representative of themselves than of others. Similarly, the applicability of ease differs depending on whether individuals judge in-group as compared to out-group members because their feelings are more representative of the in-group than the out-group (Rothman \& Hardin, 1997; Woltin et al., 2014).

Representativeness (misattribution). Feelings should be less likely to be used as an input to judgment when the informational value of the feelings has been obviated by other information (e.g., Schwarz \& Clore, 1983). Several studies employ misattribution paradigms in which participants are given another cause to which subjective ease can be attributed (e.g., difficulty due to simultaneous music; e.g., Schwarz et al., 1991). These elements are hypothesized to render subjective ease non-diagnostic for the judgment (reduce effect sizes) 
because some other source was the reason for ease, so the metacognitive inference about the meaning of personal ease is discounted (Schwarz et al., 1991; Unkelbach, 2006). In Schwarz et al. (1991), this source was music; in Ruder and Bless (2003), this source was an oddly-shaped writing space. Neither of these sources had meaning for the target judgment.

Relevance of feelings (judgment task). Multiple articles within the feelings-asinformation stream of research suggest that people are more likely to use feelings as inputs when those feelings are perceived to be relevant to the target judgment task (Greifeneder, Bless, \& Pham, 2001; Pham, 1998; Schwarz \& Clore, 1988). This is exemplified by Schwarz and Clore's (2007) perceived relevance of feelings of ease for a judgment. This concept is different from perceived informational value because, unlike that construct, relevance focuses on the bearing feelings have on the judgment task rather than the target of retrieval.

Relevance of feelings (disposition). Relevance may be influenced by such factors as individual differences (disposition) such as reliance on feelings or expertise (Schwarz \& Clore, 2007). Multiple papers within the ease-of-retrieval paradigm suggest experts are less likely to employ feelings (Ofir, 2000), and those who are more likely to trust their feelings (e.g., higher or lower experiential style; higher faith in intuition; e.g., Danziger et al., 2005; Keller \& Bless, 2009) are more likely to show the ease-of-retrieval effect (i.e., stronger effect sizes).

\section{Exploratory Methodological Moderators}

We additionally investigate potential moderators of the ease-of-retrieval effect that are mainly methodological and have few, if any theoretical implications. Thus, these moderators are more exploratory in nature.

Year. The ease-of-retrieval effect studies in question range from 1991 to present-day. We examine whether there is variation in effect sizes depending on publication year, which may be 
concurrent with changes in the methodology and the hunt for more moderators (Mooneyham, Franklin, Mrazek, \& Schooler, 2012; Schooler, 2011).

Country. The ease-of-retrieval effect has been studied across continents in America (e.g., Tormala et al., 2002), Australia (e.g., Laham, 2013), Germany (Schwarz et al., 1991), and other countries.

Publication Status. As in many other meta-analyses, the publication status of studies may be related to their effect size. Studies with nonsignificant $p$-values or small effect sizes may have been rejected by journal editors and relegated to the "filedrawer" or could be hidden within parts of unpublished dissertations (Rosenthal \& Rosnow, 2008).

Number of dependent measures. The number of measures used to measure subjective ease and the dependent variable of interest also varies widely from study to study. Some studies include only one measure of ease (e.g., Bartels \& Urminsky, 2011), while others include two (e.g., Greifeneder \& Bless, 2008) or three (e.g., Avnet, 2005). These measures are typically averaged to form a single ease-of-retrieval index. Similarly, studies measuring trait ratings or attitudes have substantial variation in their number of measures used to form a composite dependent variable. We incorporate this variability into our analyses as a measure of precision and potential measurement error for the hypothesized mediator (i.e., subjective ease) and the dependent measure of interest. When effect sizes were composed of an average of two dependent measures with differing number of items (e.g., a one-item scale and a six-item scale), we averaged the number of items for this variable (yielding 3.5 for the previous example).

Attitude versus non-attitudes. We classify the different dependent measures in this literature into two broad categories: attitude-based measures and non-attitude measures. These broad categories are meant to capture potential differences in dependent measure types (such as 
reliability, response bias, or response scale familiarity). Attitude-based measures cover multiple different types of responses (e.g., self-rated traits, policy evaluations; Ruder \& Bless, 2003;

Schwarz et al., 1991), whereas non-attitude include such measures as subjective likelihood and frequency (e.g., Sanna et al., 2002) or observable behaviors (e.g., Stephen \& Pham, 2008).

\section{A Taxonomy of Ease-of-Retrieval Effects:}

\section{Standard and Moderated Paradigms, Proximal and Distal Mediation}

To determine the extent to which ease mediates the ease-of-retrieval effect, it is necessary to identify the experimental conditions meant by the authors to conceptually replicate the original Schwarz et al. (1991) ease-of-retrieval effect. We refer to these conditions as using the standard paradigm. The remaining experimental conditions, in which authors hypothesize that the ease-of-retrieval effect will be attenuated or reversed, are said to use a moderated paradigm.

Based on this taxonomy, we construct three datasets: standard, moderated, and combined (i.e., both paradigms). The combined dataset provides the greatest variation in moderators because many moderators are held constant in each paradigm (e.g., moderator present or moderator absent). Therefore, the combined dataset is most useful for assessing the overall effectiveness of the moderators proposed in the literature to alter the size (and direction) of the ease-of-retrieval effect. That is, it provides the highest-powered tests of moderation. Also, a subset of our data includes additional effect sizes that mediation analyses, and the combined dataset is most useful in identifying the sources of moderation. That is, if a specific moderator influences the total effect size, we can check whether it has a similar impact on the indirect effect that is mediated by ease ( $a \times b$; see Figure 2 ) or it exerts influence by increasing the size of the direct effect $\left(c^{\prime}\right)$, suggesting the presence of other causal factors. The standard paradigm data provides (1) the best estimate of the size of ease-of-retrieval effect and (2) the best test of 
subjective ease as the best explanation of the ease-of-retrieval effect as originally conceived. Analyses of the total effect from the moderated dataset are included for completeness.

One second, important division in the data pertains to the relationship between the recall task and the dependent measure of interest. In some studies, subjects are asked to recall examples of assertiveness and then provide ratings of their assertiveness (e.g., Schwarz et al., 1991), or recall reasons in favor or against public transportation before evaluating public transportation (Wänke et al., 1996). In these cases, the generated examples are directly relevant for the task used for the dependent measure (often an attitude or likelihood judgment) and, therefore, constitute clear examples of the feelings-as-information hypothesis that is the focus of this metaanalysis. We refer to the effect sizes from studies of this type as proximal because the impact of subjective ease on the dependent measure is direct and does not require further assumptions about how ease should affect the dependent measure of interest.

However, there are also cases in which the few-versus-many manipulation pertains to one subject matter (e.g., reasons New York is positive or negative; Alter \& Balcetis, 2011), while the dependent measure concerns something not recalled (e.g., how far away New York feels). In these cases, beyond what is recalled in the few-versus-many manipulation, there must be an intermediary mechanism that explains the causal relationship between ease and the dependent measure (e.g., a connection between attitudes towards New York and how far away it feels). We call these distal effect sizes because there is an additional mediator between ease and the dependent measure that requires assumptions, theories, or models outside of feelings-asinformation theory. One implication of these intermediary mechanisms is that a null effect may not be inconsistent with feelings-as-information; the intervening mechanism may be wrong (i.e., the non-ease mechanism thought to affect the dependent measure, contrary to predictions, does 
not). Because of this difference in explanations, we further divide the combined, standard, and moderated datasets into two subsets that are analyzed separately: proximal and distal. Examples of proximal and distal effect sizes can be found in Table 1. We perform all analyses on both datasets; however, the proximal effect sizes are of greater interest because they are more direct tests of the focal hypothesis that cognitive feelings of ease are being used as information in the judgment process.

\section{Methodology}

\section{Literature Search}

The widespread use of the "few-versus-many" manipulation in disparate experimental literatures made keyword search ineffective because no simple set of keywords could capture the entire literature efficiently. Sets of keywords such as "ease-of-retrieval" and "retrieval fluency" did not capture all papers that forward searches of the major articles in the literature did, whereas the latter yielded all papers found by the former. Therefore, we examined forward citations of the original empirical paper that reported the ease-of-retrieval effect, Schwarz et al. (1991), and two major reviews, Schwarz (1998) and Schwarz (2004), using the ISI Web of Knowledge. We also looked at forward citations of published articles citing Schwarz et al. (1991) that employed the few-versus-many manipulation within the following ten-year period (1992-2001) ${ }^{1}$. Additionally, we searched Proquest Dissertations and Theses database for papers that had the names of the Schwarz et al. (1991; "Ease of Retrieval as Information: Another Look at the Availability Heuristic”), Schwarz (1998; (“Accessible content and accessibility experiences: The interplay of

\footnotetext{
1 These articles included Aarts \& Dijksterhuis (1999); Belli, Winkielman, Read, Schwarz, \& Lynn (1998); Broemer (2001); Dijksterhuis, Macrae, \& Haddock (1999); Grayson \& Schwarz (1999); Haddock, Rothman, \& Schwarz (1996); Haddock, Rothman, Reber, \& Schwarz (1999); Merckelbach, Wiers, Horselenberg, \& Wessel (2001); Ofir (2000); Raghubir \& Menon (1998); Rothman \& Hardin (1997); Rothman \& Schwarz (1998); Vaughn (1999); Wänke, Bless, \& Biller (1996); Wänke, Bohner, \& Jurkowitsch (1997); Winkielman \& Schwarz (2001); and Winkielman, Schwarz, \& Belli (1998).
} 
declarative and experiential information in judgment"), and Schwarz (2004; "Metacognitive Experiences in Consumer Judgment and Decision Making”) in their text as citations. Finally, we cross-referenced PsychFileDrawer.org and the Reproducibility Project Open Science Framework for any replications of papers in our search. We completed this search by April 2014.

We then contacted authors ${ }^{2}$ who had available contact information to inquire about unpublished studies, effect sizes not reported in their paper, and to ask them to verify our classification of their experimental conditions into standard and moderated paradigms. As part of this process we sent spreadsheets to individual authors that contained the effect sizes we had obtained from their publications. The spreadsheet also indicated which measures were missing and how we had interpreted their studies in terms of the standard and moderated paradigms. An example of one of these sheets for Pablo Briñol is provided in Appendix Figure A1. Example email text is provided in Appendix A.

Further, to solicit researchers for other possible file-drawer studies, we sent messages requesting unpublished data through the following listservs: ACR-L, SCP, SJDM, and SPSP.

\section{Inclusion Criteria}

We included articles using the following two criteria:

1) Presence offew-versus-many manipulation: Studies had to include a between-subjects manipulation that required writing or imagining a smaller number of examples versus a larger number of examples. We only used between-subjects manipulations given the overwhelming majority of studies were between-subjects, and because it is unclear how to interpret the withinsubject version of this task since that effect may not be entirely due to ease. We excluded conditions in which readers reviewed what other writers had produced (e.g., Wänke et al., 1996;

\footnotetext{
${ }^{2}$ We contacted first authors except when an author with multiple publications was also on the publication and was contacted, or when the first author's contact information could not be found.
} 
Weick \& Guinote, 2008) because these conditions do not require the task of interest (i.e., example generation).

When multiple numbers of arguments were present (e.g., four, eight, and 12 arguments; e.g., Belli et al., 1998; e.g., one, three, and seven arguments; e.g., Sinha \& Naykankuppam, 2013, Study 1), we only used the minimum and maximum number of arguments conditions that were of the same topic for computing effect sizes. Only three papers in our final database ultimately used more than two levels for number of arguments. ${ }^{3}$

2) Statistics: Studies needed to have enough information from which to calculate a contrast between the "few" condition and corresponding "many" condition. When information to compute effect sizes was unavailable, we contacted authors as mentioned earlier.

\section{Meta-Analytic Methodology}

We used means and standard deviations, $F$ ratios, $t$-tests, $d$ values, $r$ values, and log-odds ratios to compute effect sizes based on standard formulae (Lipsey \& Wilson, 2001; Rosenthal \& Rosnow, 2008).

Most experiments manipulated some other factor in addition to few-versus-many. Sometimes all levels were the same paradigm type (e.g., a standard paradigm might manipulate whether assertiveness or unassertiveness was the dependent measure with the expectation that these were conceptual replications). Sometimes the manipulation changed the paradigm type (e.g., control versus alternative attribution for subjective ease). In all cases, each level of the factor was used to obtain effect sizes. Three effect sizes were sought: (1) the effect of fewversus-many $(X)$ on the dependent variable of interest $(Y),(2)$ the effect of $X$ on subjective ease

\footnotetext{
${ }^{3}$ Excluding the studies that tried multiple levels of few and many conditions does not have an enormous impact on our effect size results (Standard: $r=.253$; Moderated: $r=-.178$; Overall: $r=.121$ ).
} 
$(M)$, and (3) the effect of subjective ease $(M)$ on the dependent variable of interest $(Y)$. We refer to these effect sizes as mediation triplets.

We calculated effect sizes in terms of Pearson's $r$ because of its ease of interpretation across different measures (Rosenthal \& DiMatteo, 2001). We conducted analyses of the simple correlations using Fisher's $z$ for distributional reasons, but we report all results in in terms of $r$ for interpretability (Hunter \& Schmidt, 2004; Rosenthal \& DiMatteo, 2001). We weight the effect sizes by their inverse variance (i.e., $n-3$ for Fisher's $z$ ) using random effects formulae ${ }^{4}$ from the meta-analysis literature (Borenstein et al., 2009; Hedges \& Olkin, 1985; Lipsey \& Wilson, 2001).

We averaged the $r_{X Y}$ values across effect sizes for all dependent measures with sufficient statistical information. We used all measures to prevent biases based on trying to pick only one dependent measure for each study. Effect sizes of this type were relatively rare, $21 \%$ of proximal effect sizes and $13 \%$ of distal effect sizes. For the mediation triplets, we used only one dependent measure based on which measure had sufficient statistical information available for $r_{M Y}$. When multiple measures had information for $r_{M Y}$, we used the median value (or minimum of two values when an even number of values were present); additional analyses with non-included values yielded similar results. Taking the average of the $r_{M Y}$ values for the averaged $r_{X Y}$ values could potentially violate assumptions of mediation analysis (e.g., the indirect effect is the product of two effect sizes, $a$ and $b$, and the product of averages is not the same as the average of products), so this approach was not used.

\footnotetext{
${ }^{4}$ We also note the weighted fixed-effects aggregate effect sizes are different (Standard: $r=.144$; Moderated: $r=-.173$; Overall: $r$ $=.083$ ) from our main random-effects results. However, this deviation is primarily due to unpublished effect sizes from the standard paradigm for studies that are much larger than all other studies (Yeager \& Krosnick, 2014). Removing these points reveals a weighted fixed-effects aggregate effect size that's not drastically different from the random effects results (Standard: $r=$ .241 ; Moderated: $r=-.173$; Overall: $r=.118$ ), and does not affect the conclusions from the moderator results on the total effect.
} 


\section{Publication Bias}

We assessed publication bias by examining the simple ease-of-retrieval effect, $r_{X Y}$, in two ways: trim-and-fill analysis of funnel plots (Duval \& Tweedie, 2000a, 2000b; Light \& Pillemar, 1984) and PET-PEESE (Carter \& McCullough, 2014; Stanley \& Doucouliagos, 2014).

First, the funnel plot is a graphical display of precision (here standard error) by effect size (Light \& Pillemar, 1984). In a standard funnel plot, effect sizes should converge towards a tighter estimate of an overall effect size as the studies become more precise, producing a funnel shape (Sutton, 2009). However, if there is publication bias, there will be an asymmetry in the funnel for smaller, less precise studies with near-zero effect sizes that may not have had significant findings to publish (Egger et al., 1997). The trim-and-fill algorithm (Viechtbauer, 2010) "corrects" this asymmetry by first trimming the asymmetric portion of the funnel plot, then re-estimating the mean effect size and its confidence interval for the remaining studies. Finally, the trim-and-fill algorithm re-fills in the funnel with both the trimmed studies (that created the funnel asymmetry) and their corresponding "missing" observations reflected across the mean of the funnel (Duval \& Tweedie, 2000).

Second, PET-PEESE is a method by which an effect size is extracted from the intercept of an Egger regression that is intended to represent the publication-bias adjusted effect size from a study with zero standard error (Carter \& McCullough, 2014; Stanley \& Doucouliagos, 2014). PET (Precision Effect Test) employs standard error as the predictor in this regression, and errs on the side of underestimating the true effect size. PEESE (Precision Effect Estimate with Standard Error) uses variance instead. Stanley and Doucouliagos (2014) advise that when PET yields an intercept significantly different from zero, individuals should rely on the intercept from PEESE 
as the underlying effect size. Otherwise, PET's estimate of the effect size is more accurate (but, also see Gervais, 2015).

\section{Moderator Coding}

Salience moderators. We coded the three salience moderators discussed earlier as follows. First, we coded the difference between the number of arguments in the "many" and "few" conditions as range. Second, we coded whether the measure of subjective ease on subjective ease occurred before or after the dependent measure of interest $(1=$ before, $-1=$ after $)$ as attention. Finally, we coded polarized attitude as present $(+1 ;-1$ otherwise), if such attitudes were explicitly noted in the paper (e.g., high interest in politics; crystallized attitude; e.g., Haddock, 2002; Haddock et al., 1999) or if participants were described as having expertise (which was assuming to imply a polarized attitude).

Inference moderators. We code the six inference moderators discussed earlier as follows. First, we code processing motivation (depth) based on whether processing depth or motivation was influenced by a non-involvement manipulation $(+1=$ increased, $-1=$ decreased, 0 $=$ no manipulation). Examples of manipulations that would increase processing motivation or capacity would be inducing sadness (e.g., Ruder \& Bless, 2003), boosting accuracy motivation (e.g., Aarts \& Dijksterhuis, 1999), or increasing uncertainty (e.g., Greifeneder et al., 2011a). Examples of manipulations that decrease processing motivation or capacity would be those that eat up cognitive resources (e.g., Greifeneder \& Bless, 2007) or decrease uncertainty (e.g., Greifeneder et al., 2011a). These manipulations should decrease effect sizes if depth is boosted. Second, we code processing motivation (involvement) based on whether involvement is stated to be manipulated as more (+1; e.g., higher need for cognition individuals; e.g., Tormala et al., 2002) or less (-1) personally involving than when involvement is not explicitly manipulated (0). 
Third, we code representativeness (retrieval target) based on whether the target of recall is the self $(+1)$ or not $(-1) .{ }^{5}$ Fourth, we code representativeness (misattribution) paradigms based on whether an attribution to another source (e.g., music, an unusual writing space; e.g., Ruder \& Bless, 2003; Schwarz et al., 1991) was present (+1) or not (-1). Fifth, we code relevance of feelings (judgment task) based on whether individuals are making judgments about themselves $(+1)$ or not $(-1){ }^{6}$ Sixth, we code relevance of feelings (disposition) based on whether individuals are personally more likely to see their feelings as relevant to judgment $(+1$; e.g., experiential processors, high-powered individuals; e.g., Danziger et al., 2005; Weick \& Guinote, 2008) or less likely (-1; e.g., individuals with less faith in intuition; e.g., Keller \& Bless, 2009; 0 for no manipulation).

Exploratory methodological moderators. We coded the following study characteristics as moderators as part of our exploratory analyses: (a) the year, (b) the country in which the study was published (in the US $=+1$, non-US $=-1$ ), (c) whether the study was published or unpublished $(+1=$ unpublished, $-1=$ published); (d) the number of items in the subjective ease measure; (e) the number of items in the dependent variable of interest; ${ }^{7}$ and (f) attitude dependent measure (e.g., $+1=$ attitude measure, $-1=$ all other measures). ${ }^{8}$

Taxonomy. Based on a careful reading of the authors' hypotheses, experimental conditions were classified as either a standard or a moderated paradigm. As part of our outreach

\footnotetext{
${ }^{5}$ We alternatively also coded a variable about whether the recall was episodic or semantic. The same results held for this coding scheme, which was highly correlated with self/not-self.

${ }^{6}$ We recognize this has some conceptual overlap with representativeness and may be better categorized as such; the results for both this moderator and retrieval target are consistent, and we return to these in the general discussion.

${ }^{7}$ We cap the maximum number of measures at 9 given $91 \%$ of proximal's distribution and $84 \%$ of distal's distribution fall between 1-8 measures, and all other measures use far lengthier scales that skew the distribution. 8 One question may revolve around whether attitude certainty measures are coded separately from attitude measures. These measures comprise a small portion $(<5 \%)$ of the database and do not significantly differ from any other category of dependent measure (attitude or non-attitude).
} 
to authors, we requested authors review our categorization of standard and moderated paradigm assignments for their experiments. We provided authors with the following definition of standard and moderated paradigms: "Importantly, we are separating reported results into experimental conditions that the authors present as conceptual replications of the original effect reported by Schwarz et al. (1991) -- the standard paradigm -- and conditions in which the authors change the standard paradigm in ways that they expect will moderate the effect, causing attenuation or reversal."

We also separated effect sizes based on whether they were proximal or distal effect sizes (see earlier discussion and Table 1). In some cases, a paper could contribute both proximal and distal effect sizes because multiple dependent measures were used (e.g., Alter \& Balcetis, 2011; Bartels \& Urminsky, 2011).

Coding reliability. All moderators were originally coded by the first author, and then coded a second time by at least one of two independent raters to confirm reliability. The first author was an advanced graduate student in Psychology with completed graduate coursework training. The two independent coders were undergraduate research assistants with extensive coursework in psychology and research experience. All coded variables included in the final analysis had satisfactory or better (i.e., $\kappa>.6$ ) agreement.

\section{Mediation Analysis Plan}

As noted earlier, a subset of our data includes a measure of ease-of-retrieval in addition to a dependent measure of interest, and therefore it permits statistical tests of mediation. Mediation analysis provides a computational method for decomposing the total effect $(c)$ into indirect $(a \mathbf{x}$ b) and direct $\left(c^{\prime}\right)$ effects, given the assumption that a variable, $M$, causally mediates the relationship between an independent variable, $X$, and a dependent variable, $Y$ (Baron and Kenny, 
1986; MacKinnon, Fairchild, \& Fritz, 2007; Zhao, Lynch, \& Chen, 2010; see Figure 2). ${ }^{9}$ These estimates quantify the qualitative relationships depicted in Figure 1.

The traditional explanation in the standard paradigm is that subjective ease mediates the ease-of-retrieval effect (Schwarz, 2004). In terms of the mediation model depicted in Figure 2, $a$ and $b$ should be large if the traditional explanation holds. More specifically, the traditional explanation suggests that subjective ease should fully mediate the effect, which implies that the indirect effect, $a \times b$ should be much larger than the direct effect, $c^{\prime}$. At a minimum, the traditional explanation predicts that the indirect effect should be significantly positive. If the direct effect is found to be substantial (e.g., as large as the indirect effect and significantly different than zero), then traditional explanation is inadequate insofar as a substantial direct effect suggests that one or more mediators, other than subjective ease, are involved. In the moderated paradigm, the mediation should be disrupted (i.e., indirect effect should be reduced) or some other mediator should exert a stronger influence than feelings of ease (i.e., direct effect should be increased).

For every triplet of effect sizes $\left(r_{X M}, r_{M Y}\right.$, and $\left.r_{X Y}\right)$ obtained from the literature or directly from the authors, standardized regression coefficients were computed based on the traditional mediation equations with subjective ease as the mediator of the effect of the few-versus-many manipulation on the dependent measure of interest (Baron \& Kenny, 1986; Cohen, Cohen, West, \& Aiken, 2003). These equations are:

\footnotetext{
${ }^{9}$ One area of possible debate is whether subjective ease is a "manipulation check" or a measure of an explanatory construct; we argue it is the latter. Although many studies report measures of subjective ease as a manipulation check, we believe "manipulation check" is a misnomer because subjective ease is a mediating psychological construct. Further, Fiedler et al. (2011) present simulation evidence that manipulation checks should not significantly mediate the dependent measure of interest. Following this, if subjective ease is found to often pass the mediation test, then our claim that subjective ease is a measure of a mediator, not a manipulation check, is supported.
} 


$$
\begin{gathered}
a=r_{X M} \\
b=\left(r_{M Y}-r_{X Y} * r_{X M}\right) /\left(1-r_{X M}^{2}\right) \\
c^{\prime}=\left(r_{X Y}-r_{M Y} * r_{X M}\right) /\left(1-r_{X M}^{2}\right)
\end{gathered}
$$

We did not obtain $r_{M Y}$ or estimate mediation models for studies using spotlight analyses due to the difficulty of obtaining a meaningful correlation at one standard deviation above and below another factor. ${ }^{10}$

\section{Results}

\section{Literature Search}

A total of 152 papers, published and unpublished, were found that employed the fewversus-many manipulation. As of the time of this article, no replications with publicly available results were available on PsychFileDrawer or the Open Science Framework/Reproducibility Project. ${ }^{11}$ There were 121 published papers, 23 dissertations and theses ${ }^{12}$, and eight unpublished papers (two studies were left out from a published paper, and 17 studies came from seven unpublished manuscripts). These 152 papers contained 284 studies. One study was excluded for using a within-subject design (Corby \& Homa, 2011, study 2). Other studies and conditions were excluded due to insufficient statistical information (e.g., Corby \& Homa, 2011; Florack \& Zoabi, 2003; Frederick \& Mochon, 2012; Hermann et al., 2002; Hirt et al., 2004; Kivetz \& Zhang, 2006; Lee, 2005; Ofir, 2000; Sackett, 2006; Sanna \& Schwarz, 2004; Tormala et al., 2002, study

\footnotetext{
10 We thank John Lynch, Jr., for his advice on this topic.

${ }^{11}$ However, a study from Stephen and Pham (2008) was under processing (yet not conducted as of initial submission) in the OpenScience framework database.

${ }^{12}$ We e-mailed 92 authors who had available contact information and were the common links across multiple papers, of whom $64(69.57 \%)$ responded.
} 
3; Walton \& Cohen, 2007; Wehr, 2010, Study 1; Yahalom \& Schul, 2013), as specified above.

These exclusions left 142 papers and 263 studies. Comprehensive tables with effect sizes and descriptions of studies can be found in Appendix B. The data file can be found in the Supplemental Materials.

Of the 142 papers, there were 263 studies that yielded 582 effect sizes (i.e., observations in the database): these 582 effect sizes were composed of 454 proximal and 128 distal. $^{13}$ Of these 454 proximal observations, 298 were categorized as standard paradigm observations, and 156 as moderated paradigm observations. The distal observations were composed of 92 standard paradigm and 36 moderated paradigm observations. For our mediation tests, we had 209 triplets of $r_{X M}, r_{M Y}$, and $r_{X Y}, 165$ from proximal data (of which 143 were from the standard paradigm) and 44 from distal data (of which 31 were from the standard paradigm).

A descriptive set of statistics for the 582 effect sizes split into proximal and distal can be found in Table 2.

\section{Total Effect Analyses $\left(c=r_{X Y}\right)$}

Overall effect size. All reported analyses of effect sizes and regression models used a two-level meta-analytic model with random intercepts for papers (Raudenbush \& Bryk, 2002; see Singer, 1998 for a similar model). We use a restricted maximum likelihood estimation method (Littell et al., 2006). The dependent variable was the Fisher $z$ transform of $r_{X Y}$, and all predictors were standardized. We report the mean effect sizes and $95 \%$ confidence intervals in Table 3.

\footnotetext{
13 We also analyze our results excluding the two papers from the proximal analyses that are heavily weighed by our estimation method: Yeager \& Krosnick's studies, which have several hundred participants per cell (larger than any other study), and Bares' (2007) dissertation from which has more observations than for any other paper were gathered. Removal of these papers does not affect our overall effect sizes drastically (Standard: $r=.258$; Moderated: $r=-.181$; Overall: $r=.125$ ).
} 
We first examine the proximal effect sizes. As shown in Table 3, the mean effect size for the standard paradigm was positive, $r_{X Y}=.253,95 \%$ CI $\left.[.224, .281], t(110)=17.05, p<.001\right)$, and the mean effect size for the moderated paradigm was negative, $r_{X Y}=-.178$ (95\% CI [-.215, $.140], t(52)=-9.27, p<.001)$. Both the standard and moderated paradigms rejected the null hypothesis of homogeneity based on Cochran's Q (standard: $Q(297)=720.795, p<.001 ; I^{2}=$ $58.80 \%, 95 \%$ CI $[53.19 \%, 63.73 \%]$; moderated: $Q(155)=202.26, p=.006 ; I^{2}=23.37 \%, 95 \%$ CI $[5.85 \%, 37.62 \%])$. An $I^{2}$ value corresponds to the proportion of total variation attributable to true heterogeneity and not sampling error; we caution, however, that it does not represent absolute heterogeneity (Borenstein et al., 2009; Higgins \& Thompson, 2002; Huedo-Medina et al., 2006). We also observe a grand mean effect size of the combined (i.e., standard and moderated together) dataset ${ }^{14}$ of $r_{X Y}=.121(95 \%$ CI $[.094, .149] ; t(113)=8.79, p<.001 ; Q(453)$ $=1395.33, p<.001 ; I^{2}=67.53 \%, 95 \%$ CI $\left.[64.23 \%, 70.53 \%]\right)$. We present the distribution of the individual proximal effect sizes in each paradigm in Figure 3. For the standard paradigm, 91\% of observations are greater than zero. For the moderated paradigm, $83 \%$ of observations are less than or equal to zero.

We next turn to the distal effect sizes, which are depicted in Figure 4 for the standard (panel A) and moderated (panel B) paradigms. 96\% of the standard paradigm observations are greater than zero, whereas $67 \%$ of the moderated observations are at or below zero. The standard paradigm again had a positive mean effect size $\left(r_{X Y}=.264,95 \%\right.$ CI $[.221, .307] ; t(41)=11.79, p$ $<.001 ; Q(91)=117.82, p=.031 ; I^{2}=22.76 \%, 95 \%$ CI $\left.[0 \%, 40.86 \%]\right)$, whereas the moderated paradigm had a negative mean effect size $\left(r_{X Y}=-.082,95 \%\right.$ CI $[-.158,-.005] ; t(19)=-2.23, p=$

${ }^{14}$ Alternative strategies yield similar results in proximal for nesting within studies (Standard: $r=.254$; Moderated: $r$ $=-.183$; Overall: $r=.102$ ) and within clusters of authors (Standard: $r=.232$, Moderated: $r=-.174$; Overall: $r=$ $.117)$, where clusters were defined as sets of frequent co-authors. 
$\left..038 ; Q(35)=53.075, p=.026 ; I^{2}=34.06 \%, 95 \% \mathrm{CI}[0.75 \%, 56.18 \%]\right)$. The combined dataset again had a slightly positive effect size $\left(r_{X Y}=.164,95 \% \mathrm{CI}[.128, .201]\right.$; $t(44)=8.96, p<.001$; $Q(127)=282.10, p<.001 ; I^{2}=54.98 \%, 95 \%$ CI $\left.[45.05 \%, 63.12 \%]\right)$.

Publication bias. We investigated publication bias using both trim-and-fill and PETPEESE methods (Duval \& Tweedie, 2000; Stanley \& Doucouliagos, 2014). Both methods suggest that publication bias may reduce the ease-of-retrieval effect by up to one-third in magnitude in the standard paradigm (and reduce the moderated paradigm by about a fifth). However, the null hypothesis that the true effect size is 0 is still rejected after adjusting for publication bias.

Funnel plots based on trim-and-fill analyses ${ }^{15}$ for effect sizes from standard paradigm, moderated paradigm, and combined datasets for proximal effect sizes are provided in Figure 5. In Panel A, the funnel depicts the confidence interval for the sample mean before applying the trim-and-fill algorithm. In Panel B, the funnel depicts the confidence interval after applying the trim-and-fill algorithm. In Panel C, the funnel depicts alpha contours assuming the null hypothesis (i.e., $z=0$ ) is true (white indicates non-significant, light grey .05 $<p<.10$, dark grey $p<.05$, outside of funnel $p<.01$ ). The standard paradigm had 88 potentially-missing observations imputed by trim-and-fill for an adjusted effect size estimate that did not have 0 in its confidence interval $(r=.159,95 \%$ CI $[.137, .181], z=13.78, p<.001 ; Q(385)=983.37, p<$ .001 ). Many of the imputed, potentially missing effect sizes (white circles in Figure 5B), however, occur in regions of statistical non-significance $(p>.10$, white), while fewer imputed effect sizes are in regions of marginal $(.05<p<.10$, light grey) or traditional $(.01<p<.05$,

\footnotetext{
15 One difficulty with funnel plots is that missing studies may occur due to multiple reasons, inclusive of nonsignificant results or small study effects. We employ contour-enhanced funnel plots, which illustrate the regions in which studies are statistically significant. These contours help indicate whether studies are missing from areas of the chart in which the effect sizes would emerge from non-significant studies (Palmer et al., 2008; Peters et al., 2008).
} 
darker grey; $p<.01$, outside the funnel) statistical significance. So, the asymmetry in the funnel is more likely to be due to publication bias than from other elements such as variance in study quality for smaller-sample studies (Palmer et al., 2008; Peters et al., 2008). In the moderated paradigm, no studies were filled in $(r=-.177,95 \%$ CI [-.206, -.147], $z=-11.34, p<.001 ; Q(155)$ $=202.26, p=.006)$. In the combined dataset, only 33 potentially-missing studies were filled in for an adjusted effect size estimate that did not have 0 in its confidence interval $(r=.080,95 \%$ CI $[.054, .105], z=6.01, p<.001, Q(486)=1625.62, p<.001)$.

Analogous trim-and-fill funnel plots for the distal effect sizes can be found in Figure 6 . The standard paradigm had 31 potentially-missing observations imputed by trim-and-fill for an adjusted effect size estimate that also did not have 0 in its confidence interval $(r=.188,95 \% \mathrm{CI}$ $[.154, .221], z=10.59, p<.001 ; Q(122)=222.75, p<.001)$. In the moderated paradigm, 8 studies were filled in $(r=-.013,95 \%$ CI [-.078, .052], $z=-0.387, p=.699 ; Q(43)=84.61, p<$ $.001)$. In this case, the moderated paradigm became nonsignificantly different from zero. However, given the effect sizes in the moderated paradigm are garnered from studies intended to attenuate or reverse the effect, this result is not troublesome. In the combined dataset, only 18 potentially-missing studies were filled in for an adjusted effect size estimate that did not have 0 in its confidence interval $(r=.132,95 \%$ CI $[.092, .172], z=6.39, p<.001, Q(145)=373.98, p<$ $.001)$.

Our PET-PEESE results on proximal effect sizes similarly suggest a downward correction of the effect size to account for publication bias. For the standard paradigm, the results of PET suggest a new effect size of $r=.104(95 \%$ CI $[.034, .172], t(110)=2.95, p=.004)$, while PEESE points to a more modest correction to $r=.193(95 \%$ CI $[.153, .232], t(110)=9.51, p<$ .001). Given that we reject the null hypothesis for PET (that the intercept is equal to 0 ), the value 
from PEESE is generally recommended (Carter \& McCullough, 2014; Stanley \& Doucouliagos, 2014). This adjusted value is almost a fourth reduction in the effect size and is less extreme than the trim-and-fill estimate, so only a fraction of the effect may be explained by publication bias. Our moderated paradigm results yield similar conclusions from PET $(r=-.162,95 \%$ CI [-.276, $.043], t(52)=-2.72, p=.009)$ and PEESE $(r=-.179,95 \% \operatorname{CI}[-.237,-.120], t(52)=-5.99, p<$ .001). We again opt for the PEESE estimate based on the PET-PEESE rule to select PEESE if PET is significantly different from 0 (Carter \& McCullough, 2014; Stanley \& Doucouliagos, 2014). On the combined dataset, we see a PET estimate of $r=.111$ (95\% CI [.034, .188], $t(113)$ $=2.84, p=.005)$ and a PEESE estimate of $r=.121(95 \% \mathrm{CI}[.078, .164], t(113)=5.57, p<$ .001). Therefore, we see a non-zero effect with PET-PEESE (thus we opt for PEESE), but the effect sizes warrant an adjustment towards zero from where they were originally.

Analyses on the distal effect sizes yield divergent results from trim-and-fill. The estimates for the standard paradigm for PET $(r=.02,95 \% \mathrm{CI}[-.077, .115], t(41)=0.40, p=$ $.692)$ are nonsignificant; the same was true for the moderated paradigm $(r=.053,95 \%$ CI [-.254, $365], t(19)=0.35, p=.727)$. The combined dataset also had a nonsignificant value for PET ( $r=$ $.069,95 \%$ CI $[-.048, .184], t(44)=1.19, p=.241)$. Although the PEESE values for the standard $(r=.140,95 \%$ CI $[.081, .198], t(41)=4.76, p<.001)$, moderated $(r=-.011,95 \%$ CI $[-.173$, $.151], t(19)=-0.14, p=.89)$, and combined $(r=.109,95 \% \mathrm{CI}[.041, .176], t(44)=3.22, p=$ .002) datasets were significantly different from zero, we must default to the PET values.

Summarizing, for the studies using distal effect sizes, which makes up a minority of the overall data, it is plausible that the true effect size is not significantly different from zero. However, for studies using proximal effect sizes, which are a majority of the overall data, there is evidence of publication bias (that may adjust the effect size downward by about a third or a 
fourth), but it is unlikely that the ease-of-retrieval effect is solely due to publication bias for two reasons. First, in the standard and moderated paradigm analyses, both trim-and-fill and PEESE find the lower bound of the $95 \%$ confidence interval is far from 0 relative to the mean (Borenstein et al., 2009). Second, for the standard paradigm, many studies were potentiallymissing from regions of non-significance in the contour trim-and-fill, suggesting that a filedrawer effect is likely.

Finally, we note that trim-and-fill techniques have been challenged in the literature (Johnson \& Eagly, 2014; Terrin et al., 2003), so we acknowledge that the results should be accepted with some caution. On the other hand, our results are not as susceptible to these criticisms as they might be because we greatly reduce one source of bias in the trim-and-fill estimation method (i.e., heterogeneity) by separating the analysis by paradigm and type of dependent measure in addition to presenting the combined results.

\section{Moderator Analyses}

Table 4 presents analyses for the total effect sizes $\left(r_{X Y}\right)$ based on the combined dataset $(N$ $=454)$ and the standard paradigm data only for the proximal paradigm $(N=298)$ using both a bivariate regression model for each moderator considered separately and a multiple regression model that includes all moderators. We find no concerns with collinearity diagnostics for these predictors. Each predictors' variance inflation factor (VIF) was below 10 for both the combined dataset $($ maximum VIF $=1.56)$ and the standard paradigm data (maximum VIF $=1.44)$, and the maximum condition index was below 30 (Cohen et al., 2003; 2.26 for the combined dataset and 2.12 for the standard paradigm data). The same holds true for Table 5, which depicts the same analyses for the combined dataset $(\mathrm{N}=128$, maximum $\mathrm{VIF}=2.33$, maximum condition index $=$ 
3.16) and standard paradigm data $(\mathrm{N}=92$, maximum $\mathrm{VIF}=2.14$, maximum condition index $=$ 2.99) for distal effect sizes.

Salience Moderators. Regarding the salience moderators, we find a strong negative effect of having a polarized attitude associated with lower effect sizes. This result is consistent with extant theory suggesting ease to be less prominent for those individuals (Greifeneder, Bless, \& Pham, 2011). However, we find little impact of increased range or attention (via placement of the subjective ease question, contrary to Kühnen, 2010), even in the standard paradigm.

Inference Moderators. Regarding the inference moderators, there were strong effects of manipulations of processing motivation (both depth and involvement), misattribution, and disposition. Manipulations of processing motivation that increased processing depth were negatively related to effect sizes for proximal, which is consistent with systematic processing reducing reliance on ease. For involvement-based manipulations of processing motivation, we observe a small increase in effect size when involvement is high (and decrease with lower involvement). That is, consistent with Tormala et al. (2002), individuals who have greater involvement with an issue may rely on higher order thoughts and feelings as a heuristic to judgment. With respect to representativeness, we find that misattribution paradigms, which alert participants to task difficulty being non-informative for judgment, clearly reduce (and reverse) effect sizes. Finally, with respect to relevance based on disposition, we find that people who are predisposed to use feelings for judgment have larger effect sizes for proximal effect sizes.

However, we also find two results that are inconsistent with our predictions for the inference moderators. First, we observe a reversal of our expected result for the target of retrieval. Retrieving information about the self reduces rather than increases effect sizes in the standard paradigm for proximal effect sizes. Further, we do not find evidence supporting the 
claim that making judgments about yourself leads to larger effect sizes. In fact, we find a reversal in the standard paradigm for proximal effect sizes.

Exploratory Methodological Moderators. Regarding the exploratory methodological moderators, we only observe a strong effect for publication status. Unpublished studies have lower effect sizes than published studies. This result holds both for the combined dataset and for the standard paradigm data for both proximal and distal effect sizes. However, aside from publication status, we do not see consistent results across bivariate and multiple regression models on whether other facets of the dependent measures (e.g., number of measures, type of measure) have an impact on effect sizes.

\section{Mediation Analyses: Indirect and Direct Effects}

Of the 582 values of $r_{X Y}$ in the total database, 253 also had associated values of $r_{X M}$ and $r_{M Y}$. For each of these triplets, standardized regression coefficients from the mediation models, as defined in Equations 1 - 3, were used to compute estimates of the indirect effect $(a \times b)$ and the direct effect $\left(c^{\prime}\right)$. These estimates were analyzed without transformation. ${ }^{16}$

Standard Paradigm. The usual explanation of the ease-of-retrieval effect predicts that the indirect effect $(a \times b)$ should be large, which we find. The standard paradigm data show partial mediation of the effect through subjective ease. For the standard paradigm data for proximal effect sizes, the average indirect $(a \times b)$ effect was $.114(95 \% \mathrm{CI}[.074, .154] ; t(56)=$ $5.68, p<.001 ; Q(142)=166.916, p=.075 ; I^{2}=14.93 \%, 95 \%$ CI $\left.[0 \%, 31.64 \%]\right)$. However, the average direct effect $\left(c^{\prime}\right)$ was similar in size, $.105(95 \%$ CI $[.064, .145] ; t(56)=5.19, p<.001$; $Q(142)=278.555, p<.001 ; I^{2}=49.02 \%, 95 \%$ CI $\left.[38.06 \%, 58.04 \%]\right)$, and the medians were .08 and .12 for indirect and direct effects, respectively. This indicates that subjective ease does not

\footnotetext{
${ }^{16}$ Unlike bivariate correlations, standardized regression coefficients from multiple correlations (i.e., b and c') are not bounded by -1 and +1 , so skewness is less of a concern.
} 
fully mediate the ease-of-retrieval effect. Moreover, because the direct effect $\left(c^{\prime}\right)$ is positive, it cannot be due to numerosity or evidence strength, which would otherwise yield a negative effect. Thus, the results of the analysis of mediation model estimates is mixed. The standard explanation is supported, but the large direct effect is unexplained by the constructs typically discussed in this literature.

However, distal standard paradigm effect sizes do not show much evidence of mediation by ease. The indirect effect was .046 (95\% CI $[-.029, .121], t(15)=1.32, p=.208 ; Q(30)=$ $\left.54.722, p=.004 ; I^{2}=45.18 \%, 95 \% \mathrm{CI}[16.25 \%, 64.11 \%]\right)$ and the direct effect was $.208(95 \%$ CI $[.144, .272], t(15)=6.96, p<.001 ; Q(30)=56.751, p=.002 ; I^{2}=47.14 \%, 95 \%$ CI $[19.52 \%$, 65.28\%]). The much larger size of the direct effect, and the relative lack of mediation by ease is consistent again with the conceptualization of distal effect sizes as requiring an additional step between ease and the dependent measure of interest.

Combined Dataset. For the proximal effect sizes combined dataset, the standard explanation was also supported: the indirect effect was $.096(95 \% \mathrm{CI}[.060, .132], t(56)=5.34, p$ $\left.<.001 ; Q(208)=182.149, p=.902 ; I^{2}=0 \%\right)$. The direct effect $\left(c^{\prime}\right)$ was $.019(95 \%$ CI [-.105, $.053], t(56)=1.14, p=.259 ; Q(208)=450.362, p<.001 ; I^{2}=53.81 \%, 95 \%$ CI $[45.96 \%$, $60.53 \%]$ ). However, the combined data includes a mix of standard and moderated paradigm data. As is discussed in the next section, the direct effects for the moderated paradigm are negative, so when pooled with the positive direct effects of the moderated paradigm, the result is an average direct effect near zero. For the distal effect sizes combined dataset, we observe an indirect effect of $.034\left(95 \%\right.$ CI $[-.020, .087], t(17)=1.32, p=.203 ; Q(43)=57.185, p=.072 ; I^{2}$ $=24.81 \%, 95 \%$ CI $[0 \%, 48.52 \%])$, and a direct effect of $.112(95 \%$ CI $[.034, .191], t(17)=3.02$, $\left.p=.008 ; Q(43)=116.093, p<.001 ; I^{2}=18.98 \%, 95 \% \mathrm{CI}[0 \%, 44.64 \%]\right)$. As compared to the 
indirect effect, the direct effect was much larger for the distal effect sizes, which is consistent with the distal model's operationalization as requiring another non-ease explanation between ease and dependent measure. Moderated Paradigm. For the moderated paradigm, the average direct effect is negative. For proximal effect sizes' moderated paradigm data, the average effect size of the direct effect $\left(c^{\prime}\right)$ is $-.205(95 \% \mathrm{CI}[-.273,-.137] ; t(25)=-6.18, p<.001, Q(65)=$ $\left.84.174, p=.055, I^{2}=22.78 \%, 95 \% \mathrm{CI}[0 \%, 43.55 \%]\right)$, which is a reversal of the ease effect, and is consistent with numerosity or evidence strength. However, the indirect $(a \times b)$ effect for these proximal effect sizes was significantly greater than zero, $.042(95 \%$ CI $[.010, .073] ; t(25)=2.75$, $p=.011, Q(65)=14.216, n s ; I^{2}=0 \%$, which suggests that some ease-related effect is present, but is too small to overcome the negative direct effect created by the moderator manipulation. On the other hand, for the distal effect sizes, the indirect effect was .002 (95\% CI [-.034, .037], $t(8)$ $\left.=0.11, p=.92 ; Q(12)=1.632, n s ; I^{2}=0 \%\right)$ and the direct effect was $-.121(95 \% \mathrm{CI}[-.232$, $.010], t(8)=-2.51, p=.036 ; Q(12)=15.005, p=.241)$, which again demonstrates that there is little evidence of mediation by ease for distal effect sizes.

\section{Mediation Analyses: Moderators of the Indirect and Direct Effects}

Tables 6 and 7 present moderator results for indirect $(a \times b)$ and direct $\left(c^{\prime}\right)$ effects for triplets pooled over the standard and moderated paradigms for proximal and distal, respectively (see tables in Appendix C for standard paradigm moderator results). As a reference point, Tables 6 and 7 also present estimates of the total effect $(c)$.

For salience moderators, we observe three results. Range has little effect, polarized attitudes moderate all effects, and attention has little or no effect.

For inference moderators, all moderators except involvement affect the direct effect for proximal effect sizes, suggesting they invoke non-ease processes. Representativeness based on 
retrieval target affected the direct effect as well for proximal, but it affected the indirect effect for distal effect sizes. Thus, the overall pattern of estimated coefficients is consistent with explanations that require new mediators that are typically not measured, or even identified, in the ease-of-retrieval literature.

\section{Interpreting Mediation Results: Heterogeneity, Measurement Error, and Correlated Error}

The results of the mediation portion of this meta-analysis are more complex than the single effect size analysis for $r_{X Y}$. That is, examining a histogram of all observations, plus means, and statistics such as $I^{2}$ provides a good assessment of both the effect and the amount of heterogeneity in effect size for $r_{\mathrm{XY}}$. However, when the unit of observation is a triplet of correlations that have implications for assessing mediation (i.e., indirect and direct effects), the interpretation of results is much more complicated (see Albarracin et al., 2000).

Two complications, heterogeneity and the statistical assumptions of mediation models, are particularly important. First, regarding heterogeneity, there can be dense, multidimensional clusters of points that are not evident in the marginal distributions of each measure considered separately. Importantly, the marginal means (or medians) of each measure may not be representative of any specific cluster or even any individual observation. We are particularly interested in the estimates of indirect $(a \times b)$ and direct effects $\left(c^{\prime}\right)$ for the standard paradigm because the consensus in the literature is that mediation by subjective ease should be robustly evident in this paradigm. Indeed, "full mediation" is often implied, and other potential mediators are seldom discussed (i.e., the indirect effect should be much larger than the direct effect). We examined mediation heterogeneity using the simplest methods described in Hutchinson, Kamakura, and Lynch (2000). Figure 8 (Panel A) displays each observation from the standard paradigm (where mediation is most likely) plotted using the indirect and direct effects as 
coordinates (black markers for proximal effect sizes, gray markers for distal effect sizes).

Although the central tendencies are positive, as expected, for the indirect effects (mean $=.10$, median $=.07)$ and the direct effects $($ mean $=.13$, median $=.14)$, there is considerable heterogeneity, as indicated by the size of the scatterplot. Moreover, visual inspection of Figure 8 (confirmed by k-means clustering) reveals three clusters: (1) a dense region just above the 45degree, which reflects the presence of both direct and indirect effects with the former being slightly larger, (2) a diffuse region above and left of the first, which reflects large direct effects and near zero indirect effects, and (3) a diffuse region below and right of the first, which reflects large indirect effects and near zero direct effects. Only the third cluster contains triplets that might be called full mediation. The k-means cluster analysis revealed that this third cluster includes only $27 \%$ of the observations; however, as might be expected, $98 \%$ of this cluster are proximal.

Hutchinson et al. (2000) recommend simply counting the number of observations consistent with a hypothesis as a straightforward way to mitigate aggregation biases due to heterogeneity. One simple test of consistency with full mediation is the number of observations for which the indirect effect is larger than the direct effect. Note that this is a rather weak test that favors full mediation. As can be seen in Table 8 this inequality holds for only $47 \%$ of proximal effect sizes and $13 \%$ of distal effect sizes. A simple test of mediation of any size that is consistent with the traditional explanation of the ease-or-retrieval effect is the number of observations for which the indirect effect is positive. Here the evidence is much stronger: $80 \%$ for proximal effect sizes and $74 \%$ for distal effect sizes. Overall, these analyses of heterogeneity suggest that some level of mediation is often present, but that mediation is the dominant explanation of the total effect for a relatively small set of proximal observations. Similarly, a 
positive direct, which suggests another mediator is influential, is often present ( $71 \%$ of proximal observations and $90 \%$ of distal observations; see Table 8 ). However, the direct effect is the dominant explanation of the total effect for a relatively small set of observations (about $13 \%$ of observations based on the k-means cluster analysis, of which $65 \%$ are proximal). Most observations (about 60\%) are consistent with multiple mediators. Thus, while ease often partially mediates the ease-of-retrieval effect, that is far from the whole story.

The second complication is that the assumptions of traditional mediation analyses may not hold and, if not, the resulting effect size estimates will be biased. Most published mediation analyses in the psychological literature have adopted an OLS regression model in which independent $(X)$, dependent $(Y)$, and mediator $(M)$ variables are all treated as fixed effects (e.g., Baron \& Kenny, 1986). Many methodologists have pointed out that this approach entails several very strong assumptions that are unlikely to be true (e.g., Bullock, Green, \& Ha, 2010; MacKinnon, Fairchild, \& Fritz, 2007; Zhao, Lynch, \& Chen, 2010). Two assumptions are especially problematic: no measurement error for $M$ and uncorrelated error between $M$ and $Y$. Figure 7 extends the simple mediation model depicted in Figure 2 to depict measurement error and correlated error. Measurement error in $M$ creates a negative bias in the OLS estimate of $b$ and a positive bias in $c^{\prime}$. For example, even if the true direct effect is zero, OLS will estimate c' to be greater than zero because $X$ can compensate for the measurement error in $M$. In contrast, correlated error in $M$ and $Y$ (usually assumed to be due to some unmeasured confounding variable; i.e., $\mathrm{C}$ in Figure 7) creates a positive bias in the OLS estimate of $b$ and a negative bias in $c^{\prime}$. Thus, the two problematic aspects of error structure have opposite effects. Thus, the magnitude of the combined bias is less than would be the case if measurement error and correlated error had directionally consistent biases. However, it is important to note that it is 
highly unlikely that the two biases will exactly cancel out. Moreover, the direction of the combined bias is unknown, so OLS estimates of the indirect effect could be either overestimates or underestimates (see Fritz, Kenny, and MacKinnon, 2016, for a more detail discussion).

For the ease-of-retrieval effect, plausible confounding variables include response style (e.g., Baumgartner \& Steenkamp, 2001; Podsakoff, MacKenzie, \& Podsakoff, 2012) and halo effects (e.g., people who feel they are very assertive also feel that all tasks are easy for them). None of the potential remedies for these biases that are discussed in the literature are possible for this meta-analysis because the only available data are the three correlations among the variables. ${ }^{17}$ Thus, the interpretation of our results for mediation triplets depends on the assumptions one is willing to make about error structure for $M$ and $Y$. It is important to note, however, that because of random assignment to the levels of $X$, the total effect, $r_{X Y}$, is unaffected by either measurement error or correlated error for $M$. So, it is not the ease-of-retrieval effect, but the explanation of the effect, that is at risk and dependent on strong assumptions.

To assess the potential biases due to error structure, we adjusted the estimates of the indirect and direct effects using the approach recently described by Fritz, Kenny, and MacKinnon (2014, 2016; see Appendix D). ${ }^{18}$ Figure 8 (Panel B) displays a plot of adjusted effect sizes for the standard paradigm. Table 8 reports medians and heterogeneity measures for standard paradigm effect sizes that were adjusted for measurement error in $M$ only, adjusted for correlated error between $M$ and $Y$ only, and adjusted for both types of error biases. It is important to note that these adjustments, although based on the literature, do not necessarily

\footnotetext{
17 Recommendations for avoiding these biases include more sophisticated estimation methods (e.g., structural equation models, instrumental variable methods, principal stratification, and inverse probability weighting; see MacKinnon \& Pirlott, 2015) and experimental manipulations of the mediator (e.g., Bullock, Green, \& Ha, 2010). 18 We thank Matthew Fritz and David MacKinnon for comments and advice regarding our application of their results. Of course, we are solely responsible for the analyses, including any errors they might contain.
} 
provide better estimates of the "true" effect sizes. The value of examining the adjusted estimates is in understanding the extent to which these biases might change our conclusions and the extent to which are conclusions are robust with respect to these possible biases. Ultimately, each bias acting alone changed the effect sizes in the direction consistent with our earlier discussion: adjusting for measure error made the indirect effect stronger and adjusting for correlated error made the indirect effect weaker. When both were present at plausible levels, the indirect effect was weakened. Thus, although our earlier analysis of mediation based on traditional OLS methods suggested that the direct and indirect effects were about the same in size for proximal data (see Table 3), our analyses of heterogeneity and error structure (see Table 8) strongly suggest that the indirect effect is smaller than the direct effect most of the time. However, none of the adjustments reversed or even challenged our earlier conclusions that there is considerable heterogeneity in viable explanations and that, while ease often partially mediates the ease-ofretrieval effect, full mediation is rare. Thus, "ease of retrieval" is far from the whole story, even for proximal data collected using the standard paradigm.

\section{General Discussion}

People do not always employ fact-based evidence to make decisions (Albarracin et al., 2005; Schwarz \& Clore, 1983; Schwarz, 2004; Tversky \& Kahneman, 1973, 1974). Many research traditions have investigated alternatives to the effortful evaluation of objective evidence, including use of quick heuristics (Kahneman \& Frederick, 2005; Payne, Bettman, \& Johnson, 1993), reducing negative emotions (Bettman, Luce, \& Payne, 1998), and thinking less

(Dijksterhuis, 2004; Dijksterhuis et al., 2006). A large research stream posits that people use how they feel about something as an input to judgment: the feelings-as-information framework (Schwarz \& Clore, 1988). In this tradition, affective feelings, cognitive feelings, and bodily 
experiences such as facial feedback inform the decision-making process (Greifeneder, Bless, \& Pham, 2007; Schwarz, \& Clore, 2007; Stepper \& Strack, 1993).

This meta-analysis examined a frequent instantiation of the impact of cognitive, the easeof-retrieval effect, and the results have clear implications for the more general question of how feelings are used in judgment. In the ease-of-retrieval effect, individuals generate varying numbers of examples of content and are hypothesized to employ feelings of ease experienced in this task instead of alternative inputs to judgment (Schwarz et al., 1991).

We analyzed 582 effect sizes from 263 studies in 142 papers. These effect sizes were based on dependent measures that were either proximal $(\mathrm{N}=454)$ or distal $(\mathrm{N}=128)$ in their hypothesized relationship to subjective ease. 298 proximal and 92 distal effect sizes were from experimental conditions using the standard paradigm (i.e., authors were attempting to conceptually replicate the original effect reported by Schwarz et al., 1991); 156 proximal and 36 distal effect sizes were from experimental conditions using moderated paradigms in which authors were attempting to reduce or reverse the ease-of-retrieval effect. Additionally, we were able to conduct mediation analyses for 209 proximal and 44 distal effect sizes, decomposing each total effect into an indirect $(a \times b)$ and a direct $\left(c^{\prime}\right)$ effect.

The results of our analyses have several implications for feelings-as-information theory and for metacognition, in general. We focus on the implications from the proximal paradigm because they represent results under "ideal conditions" for demonstrating that cognitive feelings are a mediating mechanism.

First, on average, the standard paradigm exhibits a robust, medium-sized effect $\left(r_{X Y}=.25\right.$ for proximal, .26 for distal) of the few-versus-many manipulation on a wide variety of judgment tasks. Publication bias was found to be present. We estimate that it reduces the average effect 
size by about one third or a fourth in the standard paradigm for proximal data, leaving most of the effect to be explained by other factors. Therefore, we find robust evidence that inductions of a cognitive feeling (i.e., subjective ease) influences judgment.

Second, about half of the ease-of-retrieval effect in standard paradigms that use proximal dependent measures is mediated by subjective ease when the traditional OLS mediation model is used to estimate indirect and direct effects (on average, $a \times b=.11$ and $c^{\prime}=.11$, see Table 3). This supports the standard explanation of the effect and presents convincing evidence of the use of feelings as inputs to judgment. However, it also suggests that other mediators are commonly present, but seldom identified. The standard explanation survived analyses that incorporated heterogeneity, measurement error, and correlated error. However, the estimated size of the indirect was further reduced in these analyses, while the estimated direct effect was increased. This mediation analysis serves as a call to action for researchers to find new theories and experimental paradigms that will explicate the robust, and unexplained, direct effect uncovered in this meta-analysis. Finally, studies characterized as distal based on having measures being less directly connected to ease had a far smaller indirect effect in the standard paradigm, supporting the distinction between proximal and distal.

Third, for moderated paradigms for proximal effect sizes, the indirect effect is much smaller than for the standard paradigm (but still significantly positive), and the direct effect is negative and larger in magnitude. These results strongly suggest that other mediators are at work in the moderated paradigm.

Fourth, several moderators were found to contribute to variations in effect size (see Table 4). Importantly, five moderators were designed to represent the types of moderators of feelingsas-information posited elsewhere in the literature (Greifeneder, Bless, \& Pham, 2011), which 
appeared as manipulations in the moderated paradigms. Thus, they inform us both about the operation of feelings as information and possible explanations of the observed differences between the standard and moderated paradigms. All five moderators were found to account for significant amounts of the variation in effect sizes in the total database.

For salience moderators (i.e., those affecting the experience and accessibility of subjective ease), we found two important results: one positive and one null. Polarized attitudes reduced the ease-of-retrieval effect. For these participants who had competing inputs to ease (e.g., a polarized attitude for politics; e.g., Haddock, 2002), effect sizes were negative. However, contrary to what Kühnen (2010) argues, we found only a small, non-significant effect of the subjective ease question appearing before the dependent measure (versus after or no question) in any dataset.

For inference moderators (i.e., those affecting the relationship between ease and the dependent measure), we found several important results for proximal effect sizes. Manipulations of processing motivation that increased processing depth (but were not related to involvement) reduced effect sizes, which is suggestive that increased cognitive resources made systematic processing strategies more likely (Chaiken et al., 1989). However, manipulations of processing motivation that increased involvement were positively related to the ease-of-retrieval effect, which is consistent with the Tormala et al. (2002) framework. Participants who have heightened personal relevance may be more cognizant of their higher order feelings. Further, representativeness (misattribution) reduced the ease-of-retrieval effect, consistent with the hypothesized reduced informativeness of cognitive feelings (Greifeneder, Bless, \& Pham, 2011). Finally, people predisposed toward using cognitive feelings exhibited larger ease-of-retrieval effects. 
Fifth, when the indirect and direct effect sizes were analyzed separately, many moderators were found to affect one, but not the other (see Tables 6 and 7). For salience moderators of proximal effect sizes, the polarized attitude moderator influenced the indirect and direct effect sizes. In contrast, the inference moderators affected direct effect sizes much more than indirect effect sizes for proximal effect sizes. This is consistent with the hypothesis that the moderator manipulations used in the literature achieved their results mainly by introducing new mediators that had effects opposite to those of subjective ease.

Sixth, two moderators that were based on degree of self-reference (i.e., representativeness [retrieval target] and relevance [judgment task]) were not consistent with our initial predictions and were reversed for the standard paradigm for proximal effect sizes. This result may mean that these moderators are less related to representativeness and relevance, but instead function similarly to depth of processing motivation. That is, self-referential retrieval and judgment may encourage more systematic processing (Chaiken et al., 1989).

Finally, we find few methodological factors that have a large influence on proximal or distal effect sizes. That the ease-of-retrieval effect is robust across these manipulations supports the usefulness of the manipulation in the span of inductions of cognitive feelings to be used as information, and it diminishes concerns about other possible methodological artifacts.

\section{Methodological Implications for Few-Versus-Many Studies}

Our meta-analysis also has implications for ease-of-retrieval studies in the future, inclusive of the way the few-versus-many manipulation is conducted.

First, while our work suggests no aggregate differences between whether the ease question is placed before or after the dependent measure, there may be reason to place the question after the dependent measure to avoid demand characteristics explanations (Kühnen, 
2010). In some situations, however, there may be theory-driven reasons for including the ease question before the dependent measure (e.g., salience; Greifeneder, Bless, \& Pham, 2011; see also Danziger et al., 2005). Therefore, the exact placement of this question should consider both concerns. However, we also recommend that studies that manipulate the placement of the ease question explicitly test whether the placement influences the results in a specific paper (see Feldman \& Lynch, 1988).

Second, we recommend increased sample sizes to increase power. In a simple two-cell design, given our effect size, an experimenter would need to run approximately 58 participants per cell for proximal and 53 for distal to achieve a power of .8. In the standard paradigm for the proximal model in this meta-analysis, we find that, when excluding the largest designs $(\mathrm{N}>$ 300 ), an average of 25 participants are run per cell, which would only be powered at .45 for each two-cell comparison. In the distal paradigm, there were only 30 participants per cell, leading to a power estimate of .56 . We recognize that we reduced power by splitting designs by moderators and that, in many cases, the full ANOVA had more statistical power than disaggregated two-cell comparisons due to pooled estimates of the error term (Rosenthal, Rosnow, \& Rubin, 2000). However, as illustrated by our meta-analyses, splitting data into standard and moderated paradigms enables informative tests of mediation.

\section{Broader Implications of this Meta-Analysis}

This meta-analysis arrives at an important time within the fields of social psychology, consumer behavior, and judgment and decision-making. Many well-known effects are being revisited because of failures to replicate (e.g., behavioral priming; Doyen et al., 2012; Harris et al., 2013; Rohrer et al., 2015; Shanks et al., 2013), and many researchers are engaging in debates over the existence of published effects (e.g., choice overload: Chernev, Bockenholt, \& Goodman, 
2015; Scheibehenne, Greifeneder, \& Todd, 2010; unconscious thought theory: Nieuwenstein et al., 2015). Due to these challenges, many authors of previously published effects are reluctant to provide information, data, or even communicate about their prior work. The robustness of the ease-of-retrieval effect found in this meta-analysis presents a case in which published effects are not overly controversial. Many authors who were contacted for data were not only willing to respond, but often provided missing data and unpublished studies with non-significant results or with offers to contact other colleagues for their file-drawer contents. Thus, this meta-analysis underscores the value of sharing data and experimental details.

More substantively, we report that a commonly-employed manipulation leads to an easeof-retrieval effect of moderate size. This result is important due to the strong connection of this effect to other phenomena in psychology such as the availability heuristic (Tversky \& Kahneman, 1973) and various fluency effects (Alter \& Oppenheimer, 2009). This manipulation is one cornerstone of a broader set of ideas about the impact of cognitive feelings as information in judgment and decision-making (Greifeneder, Bless, \& Pham, 2011; Schwarz \& Clore, 2007).

This meta-analysis also extends the boundaries of other meta-analytic endeavors by examining the proposed mediator of an effect in addition to the effect itself. This approach allows the total effect to be decomposed into an indirect effect and a direct effect. Thus, the adequacy of the proposed mediator can be tested, in addition to its existence. Moreover, moderators can be related to the direct and indirect effects, shedding light on the mechanisms of moderation. Finally, when substantial direct effects are revealed by the meta-analysis (as was the case here), this serves to motivate future research to uncover the associated mediators.

Finally, we believe this meta-analysis serves as a call for pre-registered, large-scale replications of the broad category of effects using highly-powered studies. Several studies in the 
database relied on smaller samples compared to what others advocate (e.g., $\mathrm{n}>30$; Simmons et al., 2011). It is prudent to recommend pre-registered, pretested (in terms of number of "few" and "many" arguments), high-powered replications to demonstrate ease-of-retrieval across a variety of policy, consumer, health, and other domains. These pre-registered replications ensure that there is no cherry-picking of dependent-measures.

\section{Potential Limitations}

Data availability due to the passage of time was a major factor in being able to attain missing information, especially from early research. Notably, we had far fewer triplets of correlations because less than half of the studies that included a subjective ease question reported $r_{M Y}$. We thus faced two layers of publication bias: those studies that were not published due to failing to find significant results, and those studies with significant results but incomplete reporting (especially, no correlation between ease and the dependent measure). When reaching out to authors we encountered multiple instances of inability to recover these missing correlations because the raw data were no longer available.

Another source of missing data arises when the goal of using the few-versus-many manipulation is simply to provide an alternative procedure for manipulating another construct (e.g., connectedness with a future self; Bartels \& Urminsky, 2011). Thus, there may be other filedrawers filled with ease-of-retrieval studies in which the investigation was not interested in ease-of-retrieval per se (i.e., distal studies).

Further, we recognize that some studies that rely on the ease-of-retrieval effect do not use the few-versus-many manipulation (e.g., Herzog, Hansen, \& Wänke, 2007; Raghubir \& Menon, 2001). In this meta-analysis, we chose to concentrate solely on the few-versus-many 
manipulation to ensure that we had comparable effect sizes (when accounting for proximal and distal).

\section{Future Directions}

Our meta-analysis revealed that subjective ease is, at most, a partial mediator of the easeof-retrieval effect. Thus, one important future direction is to explore alternative explanations, such as unrequested cognitions (Tormala et al., 2007; but see Wänke et al., 1996). The addition of questions to measure these and other explanations is straightforward.

Second, future research should examine the ecological validity of subjective ease, as generated by the few-versus-many manipulation (see Hertwig et al., 2013). While work in the field has established how naïve beliefs about ease may factor into everyday judgments (Schwarz, 2004), researchers have only occasionally asked whether the attributions drawn by individuals are beneficial or detrimental (Todd \& Gigerenzer, 2012). That is, feelings may be "nonnormative" as decision inputs, but they may not be "sub-optimal" from a broader perspective. For example, Pham et al. (2012) demonstrate that peoples' predictions may be improved through relying on their feelings based on the few-versus-manipulation. Future research should examine how and when relying on feelings of ease may be adaptive or maladaptive.

\section{Conclusions}

How people rely on their feelings has been a strong area of research for several decades (Greifender, Bless, \& Pham, 2011; Schwarz \& Clore, 1983, 2007; Zajonc \& Markus, 1982).

Substantive research topics have spanned both affective (e.g., sadness; Lerner \& Tiedens, 2001) and cognitive (e.g., ease; Whittlesea, 1993) feelings as they apply to a large variety of outcomes. One often-studied cognitive feeling has been the subjective ease of recall for judgment-related examples. 
This meta-analysis addressed the question, "Does ease mediate the ease-of-retrieval effect?" Our results suggest the answer is "Yes, but ..." We found that the effect in the standard paradigm is robust for proximal effect sizes, although up to one-third of the effect may be due to publication bias and the effect can be reduced even more by heterogeneity and correlated error. These results also speak to the role of feelings as decision inputs within the feelings-asinformation theoretical framework. As for our focal question, we found that subjective ease is a robust mediator, but that an unexplained direct effect is equally robust in both standard and moderated paradigms. For moderated paradigms, authors have identified and manipulated specific theory-based variables. However, the large residual direct effect for standard paradigms serves as a call to action for future research to answer the question, "What else mediates the ease-of-retrieval effect?" 


\section{References}

References marked with an asterisk indicate studies included in the meta-analysis.

*Aarts, H., \& Dijksterhuis, A. (1999). How often did I do it? Experienced ease of retrieval and frequency estimates of past behavior. Acta Psychologica, 103(1-2), 77-89. http://dx.doi.org/10.1016/S0001-6918(99)00035-9

*Aladjem, M. (2010). On the affective influences of attitude importance and product involvement on judgment and choice (Doctoral Dissertation). Retrieved from Proquest Dissertations and Theses.

Albarracin, D., Johnson, B.T., \& Zanna, M.P. (2005). The Handbook of Attitudes. Mahwah, NJ: Lawrence Erlbaum Associates.

Albarracin, D., Johnson, B.T., Fishbein, M., \& Muellerleile, P.A. (2001). Theories of Reasoned Action and Planned Behavior as Models of Condom Use: A Meta-Analysis. Psychological Bulletin, 127 (1), 142-161. http://dx.doi.org/10.1037/0033-2909.127.1.142

*Alter, A.L., \& Balcetis, E. (2010). Fondness makes the distance grow shorter: Desired locations seem closer because they seem more vivid. Journal of Experimental Social Psychology, 47, 16-21. http://dx.doi.org/10.1016/j.jesp.2010.07.018

Alter, A. L., \& Oppenheimer, D.M. (2009). Uniting the tribes of fluency to form a metacognitive nation. Personality and Social Psychology Review, 13(2), 219-235. http://dx.doi.org/10.1177/1088868309341564

*Angle, J.W. (2012). A Unified Theory of Consumer Response to Self-Concept Threat (Doctoral Dissertation). Retrieved from Proquest Dissertations and Theses. 
*Armitage, C. J. (2007). Changing past behavior without means of a time machine: Effects on future behavioral decisions. Social Cognition, 25(6), 761-777. http://dx.doi.org/10.1521/soco.2007.25.6.761

*Ask, K., Greifeneder, R., \& Reinhard, M. (2012). On the ease of (dis)believing: The role of accessibility experiences in credibility judgments. Applied Cognitive Psychology, 26(5), 779-784. http://dx.doi.org/10.1002/acp.2859

*Avnet, T. (2005). To Trust or Not to Trust One's Feelings: The Metacognitive Processing of Feelings (Doctoral Dissertation). Retrieved from Proquest Dissertations and Theses.

*Avnet, T., Pham, M.T., \& Stephen, A.T. (2012). Consumers' trust in feelings as information. Journal of Consumer Research, 39(4), 720-735. http://dx.doi.org/10.1086/664978

*Bares, C.B. (2007). The Development and Influence of Subjective Experiences on Children's Thinking: Implications for Cognitive-Behavioral Therapy (Doctoral Dissertation). Retrieved from Proquest Dissertations and Theses.

Bargh, J. A., Lombardi, W. J., \& E. T. Higgins (1988). Automaticity of Chronically Accessible Constructs in Person x Situation Effects on Person Perception: It's Just a Matter of Time. Journal of Personality and Social Psychology, 55 (4), 599-605. https://doi.org/10.1037/0022-3514.55.4.599

Baron, R. M., \& Kenny, D.A. (1986). The moderator-mediator variable distinction in social psychological research: Conceptual, strategic, and statistical considerations. Journal of Personality and Social Psychology, 51(6), 1173-1182. http://dx.doi.org/10.1037/0022$\underline{3514.51 .6 .1173}$ 
*Bartels, D. M., \& Urminsky, O. (2011). On intertemporal selfishness: How the perceived instability of identity underlies impatient consumption. Journal of Consumer Research, 38(1), 182-198. http://dx.doi.org/10.1086/658339

Baumgartner, H. \& Steenkamp, J. E. M. (2001). Response styles in marketing research: A crossnational investigation. Journal of Marketing Research, 38(2), 143-156. http://dx.doi.org/10.1509/jmkr.38.2.143.18840

*Beck, J. (2004). Context Effects on Metamemory Assessments (Doctoral Dissertation). Retrieved from Proquest Dissertations and Theses.

*Belli, R. F., Winkielman, P., Read, J.D., Schwarz, N., \& Lynn, S.J. (1998). Recalling more childhood events leads to judgment of poorer memory: Implications for the recovered/false memory debate. Psychonomic Bulletin \& Review, 5(2), 318-323. http://dx.doi.org/10.3758/BF03212958

Bettman, J. R., Luce, M. F., \& Payne, J. W. (1998). Constructive Consumer Choice Processes. Journal of Consumer Research, 25 (3), 187-217. http://dx.doi.org/10.1086/209535

Beyth-Marom,R., \& Fischhoff, B. (1977). Direct measures of availability and judgments of category frequency. Bulletin of the Psychonomic Society, 9(3), 236-238. http://dx.doi.org/10.3758/BF03336986

*Bianchi, M., Machunsky, M., Steffens, M.C., \& Mummendey, A. (2009). Like me or like us: Is ingroup projection just social projection? Experimental Psychology, 56(3), 198-205. http://dx.doi.org/10.1027/1618-3169.56.3.198

*Biswas, D., Keller, L.R., \& Burman, B. (2012). Making probability judgments of future product failures: The Role of mental unpacking. Journal of Consumer Psychology, 22(2), 237248. http://dx.doi.org/10.1016/j.jcps.2011.03.002 
*Bohner, G., Danner, U.N., Siebler, F., \& Samson, G.B. (2002). Rape myth acceptance and judgments of vulnerability to sexual assault: An internet experiment. Experimental Psychology, 49(4), 257-269. http://dx.doi.org/10.1026//1618-3169.49.4.257

Borenstein, M., Hedges, L.V., Higgins, J.P.T., \& Rothstein, H.R. (2009). Introduction to metaanalysis. West Sussex, UK: Wiley.

Boutron, I., Dutton, S., Ravaud, P., \& Altman, D. G. (2010). Reporting and interpretation of randomized controlled trials with statistically nonsignificant results for primary outcomes. Journal of the American Medical Association, 303, 2058-64. https://doi.org/10.1001/jama.2010.651

*Briñol, P., Petty, R.E., \& Tormala, Z.L. (2006). The malleable meaning of subjective ease. Psychological Science, 17(3), 200-206. http://dx.doi.org/10.1111/j.1467$\underline{9280.2006 .01686 . x}$

*Broemer, P. (2001). Ease of recall moderates the impact of relationship-related goals on judgments of interpersonal closeness. Journal of Experimental Social Psychology, 37(3), 261-266. http://dx.doi.org/10.1006/jesp.2000.1453

*Bulbul, C. (2007). When Consumers Choose to Restrict Their Options: Influence of Concrete and Abstract Regret on Choice Set Size Preference (Doctoral Dissertation). Retrieved from Proquest Dissertations and Theses.

Bullock, J.G., Green, D.P., \& Ha, S.E. (2010). Yes, but what's the mechanism? (Don't expect an easy answer). Journal of Personality and Social Psychology, 98(4), 550-558. http://dx.doi.org/10.1037/a0018933

Cameron, C. D., Brown-Iannuzzi, J. L., \& Payne, B. K. (2012). Sequential Priming Measures of Implicit Social Cognition: A Meta-Analysis of Associations With Behavior and Explicit 
Attitudes. Personality and Social Psychology Review, 16 (4), 330-350.

http://dx.doi.org/10.1177/1088868312440047

${ }^{*}$ Carter, S.E., \& Sanna, L.J. (2008). It's not just what you say but when you say it: Selfpresentation and temporal construal. Journal of Experimental Social Psychology, 44(5), 1339-1345. http://dx.doi.org/10.1016/j.jesp.2008.03.017

*Carter, T., \& Dunning, D. (2011). Ease-of-Retrieval. Unpublished raw data.

Carter, E. C., \& McCullough, M. E. (2014). Publication bias and the limited strength model of self-control: has the evidence for ego depletion been overestimated? Frontiers in Psychology, 5, 1-11. http://dx.doi.org/10.3389/fpsyg.2014.00823

*Caruso, E. M. (2008). Use of experienced retrieval ease in self and social judgments. Journal of Experimental Social Psychology, 44(1), 148-155. http://dx.doi.org/10.1016/j.jesp.2006.11.003

*Caruso, E.M., Mead, N.L., \& Weingarten, E. (2011). Ease-of-Retrieval. Unpublished raw data.

Chaiken, S., Liberman, A., \& Eagly, A.H. (1989). Heuristic and systematic information processing within and beyond the persuasion context. In J.S. Uleman, \& J.A. Bargh (Eds.), Unintended thought (212-252). New York, NY: The Guilford Press.

*Chang, C. (2010). The effects of retrieval ease on health issue judgments: Implications for campaign strategies. Health Communication, 25(8), 670-680. http://dx.doi.org/10.1080/10410236.2010.521907

*Cheng, C. (2005). Bicultural Identities: Determinants, Processes, and Effects (Doctoral Dissertation). Retrieved from Proquest Dissertations and Theses. 
Chernev, A., Bockenholt, U., \& Goodman, J. (2015). Choice overload: Conceptual review and meta-Analysis. Journal of Consumer Psychology. $\underline{\text { http://dx.doi.org/10.1016/j.jcps.2014.08.002 }}$

Clore, G. A. (1992). Cognitive phenomenology: Feelings and the construction of judgment. In Martin \& Tesser (Eds.), The construction of social judgments. Hillsdale: Erlbaum, pp. 133-163.

*Crescioni, A.W. (2012). The Frayed Edges of Willpower: Perceptions of Stress Impair SelfRegulatory Performance (Doctoral Dissertation). Retrieved from Proquest Dissertations and Theses.

Cohen, J., Cohen, P., West, S.G., \& Aiken, L.S. (2003). Applied multiple regression/correlation analysis for the behavioral sciences $\left(3^{\text {rd }}\right.$ ed). Mahwah, NJ: Erlbaum.

Corby, K., \& Homa, D. (2011). The enduring effect of availability. The American Journal of Psychology, 124(2), 189-202. http://dx.doi.org/10.5406/amerjpsyc.124.2.0189

*Cutright, K.M., Bettman, J.R., \& Fitzsimons, G.J. (2013). Putting brands in their place: How a lack of control keeps brands contained. Journal of Marketing Research, 50(3), 365-377. http://dx.doi.org/10.1509/jmr.10.0202

*Danziger, S., Moran, S., \& Rafaely, V. (2006). The influence of ease of retrieval on judgment as a function of attention to subjective experience. Journal of Consumer Psychology, 16(2), 191-195. http://dx.doi.org/10.1207/s15327663jcp1602 9

De Los Reyes, A., Kundey, S. M. A., \& Wang, M. (2011). The end of the primary outcome measure: A research agenda for constructing its replacement. Clinical Psychology Review, 31 (5), 829-38. https://doi.org/10.1016/j.cpr.2011.03.011 
*DeMarree, K.G., Loersch, C., Briñol, P., Petty, R.E., Payne, B.K., \& Rucker, D.D. (2012). From primed construct to motivated behavior: Validation processes in goal pursuit. Personality and Social Psychology Bulletin, 38(12), 1659-1670. http://dx.doi.org/10.1177/0146167212458328

*DeMotta, Y. (2012). Causal Controllability and Consumer Response to Charitable Appeals (Doctoral Dissertation). Retrieved from Proquest Dissertations and Theses.

*Deval, H. (2010). The Role of Accessibility Experiences in Attitude Formation: Effects of OnLine versus Memory-Based Processing (Doctoral Dissertation). Retrieved from Proquest Dissertations and Theses.

Dijksterhuis, A. (2004). Think Different: The Merits of Unconscious Thought in Preference Development and Decision Making. Journal of Personality and Social Psychology, 87 (5), 586-598. http://dx.doi.org/10.1037/0022-3514.87.5.586

Dijksterhuis, A., Bos, M. W., Nordgren, L. F., \& van Baaren, R. B. (2006). On Making the Right Choice: The Deliberation-Without-Attention Effect. Science, 311 (5763), 1005-1007. http://dx.doi.org/10.1126/science.1121629

*Dijksterhuis, A., Macrae, C.N., \& Haddock, G. (1999). When recollective experiences matter: Subjective ease of retrieval and stereotyping. Personality and Social Psychology Bulletin, 25(6), 766-774. http://dx.doi.org/10.1177/0146167299025006010

Ditlevsen, S., Christensen, U., Lynch, J., Damsgaard, M. T., \& Keiding, N. (2005). The mediation proportion: A structural equation approach for estimating the proportion of exposure effect on outcome explained by an intermediate variable. Epidemiology, 16(1), 114-120. http://dx.doi.org/10.1097/01.ede.0000147107.76079.07 
Doyen, S., Klein, O., Pichon, C., \& Cleeremans, A. (2012). Behavioral priming: It's all in the mind, but whose mind? PLoS ONE, 7(1), 1-7. http://dx.doi.org/10.1371/journal.pone.0029081

Duval, S., \& Tweedie, R. (2000). Trim and fill: A simple funnel-plot-based method of testing and adjusting for publication bias in meta-analysis. Biometrics, 56(2), 455-463. http://dx.doi.org/10.1111/j.0006-341X.2000.00455.x

*Echterhoff, G., \& Hirst, W. (2006). Thinking about memories for everyday and shocking events: Do people use ease-of-retrieval cues in memory judgments? Memory \& Cognition, 34(4), 763-775. http://dx.doi.org/10.3758/BF03193424

Egger, M., Smith, G.D., Schneider, M., \& Minder, C. (1997). Bias in meta-analysis detected by a simple, graphical test. British Medical Journal, 315(7109), 629-634. http://dx.doi.org/10.1136/bmj.315.7109.629

*Ehrlinger, J.M. (2004). Complexity Neglect: Psychological Sources of the Failure to Anticipate Unintended Consequences (Doctoral Dissertation). Retrieved from Proquest Dissertations and Theses.

*Eibach, R.P., Libby, L.K., \& Gilovich, T.D. (2003). When the change in the self is mistaken for change in the world. Journal of Personality and Social Psychology, 84 (5), 917-931. http://dx.doi.org/10.1037/0022-3514.84.5.917

Einhorn, H. J., \& Hogarth, R. M. (1981). Behavioral Decision Theory: Processes of Judgment and Choice. Annual Review of Psychology, 32, 53-88. https://doi.org/10.1146/annurev.ps.32.020181.000413 
*Etcheverry, P.E., Le, B., \& Hoffman, N. G. (2013). Predictors of friend approval for romantic relationships. Personal Relationships, 20, 69-83. http://dx.doi.org/10.1111/j.1475$\underline{6811.2012 .01397 . x}$

*Etkin, J., \& Ratner, R.K. (2013). Goal pursuit now and later: Temporal compatibility of different versus similar means. Journal of Consumer Research, 39(5), 1085-1099. http://dx.doi.org/10.1086/667203

Fairchild, A. J., MacKinnon, D. P., Taborga, M. P., \& Taylor, A. B. (2009). R^2 effect-size measures for mediation analysis. Behavior Research Methods, 41(2), 486-498. http://dx.doi.org/10.3758/BRM.41.2.486

Feldman, J. M., \& Lynch, J. G. (1988). Self-Generated Validity and Other Effects of Measurement on Belief, Attitude, Intention, and Behavior. Journal of Applied Psychology, 73 (3), 421-435. http://dx.doi.org/10.1037/0021-9010.73.3.421

Fiedler, K., Schott, M., \& Meiser, T. (2011). What mediation analysis can (not) do. Journal of Experimental Social Psychology, 47, 1231-1236.

$\underline{\text { http://dx.doi.org/10.1016/j.jesp.2011.05.007 }}$

Florack, A., \& Zoabi, H. (2003). Risk behavior among stock transactions: When investors are thoughtful. Zeitschrift fur Sozialpsychologie, 34, 65-78. http://dx.doi.org/10.1024//0044$\underline{3514.34 .2 .65}$

*Fox, C.R. (2006). The availability heuristic in the classroom: How soliciting more criticism can boost your course ratings. Judgment and Decision Making, 1(1), 86-90.

Frederick, S., \& Mochon, D. (2012). Ease-of-retrieval and anchoring. Paper presented at 4School Conference, New York, New York. 
Fritz, M.S., Kenny, D.A., \& MacKinnon, D.P. (2016). The opposing effects of simultaneously ignoring measurement error and omitting confounders in a single-mediator model. Multivariate Behavioral Research, 51 (5), 681-97. https://doi.org/10.1080/00273171.2016.1224154

*Fuller, E.W., McIntyre, R.B., \& Oberleitner, D.E. (2013). Engineering academic performance with selective retrieval: the benefits of implied ability. Journal of Applied Social Psychology, 43(11), 2195-2202. http://dx.doi.org/10.1111/jasp.12170

*Gawronski, B. (2003). Implicational schemata and the correspondence bias: On the diagnostic value of situationally constrained behavior. Journal of Personality and Social Psychology, 84(6), 1154-1171. http://dx.doi.org/10.1037/0022-3514.84.6.1154

*Gawronski, B., \& Bodenhausen, G.V. (2003). Exemplar effects on implicit social cognition: The role of accessible content versus accessibility experiences. Unpublished Manuscript.

*Gawronski, B., \& Bodenhausen, G.V. (2005). Accessibility effects on implicit social cognition: The role of knowledge activation and retrieval experiences. Journal of Personality and Social Psychology, 89(5), 672-685. http://dx.doi.org/10.1037/0022-3514.89.5.672

*Gawronski, B., Bodenhausen, G.V., \& Banse, R. (2005). We are, therefore they aren't: Ingroup construal as a standard of comparison for outgroup judgments. Journal of Experimental Social Psychology, 41(5), 515-526. http://dx.doi.org/10.1016/j.jesp.2004.11.002

*Gershoff, A.D., Mukherjee, A., \& Mukhopadhyay, A. (2007). What's not to like? Preference asymmetry in the false consensus effect. Journal of Consumer Research, 35(1), 119-125. http://dx.doi.org/10.1086/524416

Gervais, W. (2015, June). Putting PET-PEESE to the test. Retrieved from http://willgervais.com/blog/2015/6/25/putting-pet-peese-to-the-test-1. 
Gigerenzer, G., \& Selten, R. (2002). Bounded rationality: The adaptive toolbox. Cambridge, MA: The MIT Press.

*Gomillion, S. (2012). Ease-of-Retrieval. Unpublished raw data.

*Grayson, C. E., \& Schwarz, N. (1999). Beliefs influence information processing strategies: Declarative and experiential information in risk management. Social Cognition, 17(1), 118. http://dx.doi.org/10.1521/soco.1999.17.1.1

*Greifeneder, R. \& Bless, H. (2007). Relying on accessible content versus accessibility experiences: The case of processing capacity. Social Cognition, 25(6), 853-881. http://dx.doi.org/10.1521/soco.2007.25.6.853

*Greifeneder, R. \& Bless, H. (2008). Depression and reliance on ease-of-retrieval experiences. European Journal of Social Psychology, 38(2), 213-230. http://dx.doi.org/10.1002/ejsp.451

Greifeneder, R., Bless, H., \& Pham, M. T. (2011). When Do People Rely on Affective and Cognitive Feelings in Judgment? A Review. Personality and Social Psychology Review, 15, 107-141. http://dx.doi.org/10.1177/1088868310367640

*Greifeneder, R., Müller, P., Stahlberg, D., Van den Bos, K., \& Bless, H. (2011a). Beyond procedure's content: The role of accessibility experiences and personality uncertainty in procedural justice judgments. Experimental Psychology, 58(5), 341-352. http://dx.doi.org/10.1027/1618-3169/a000101

*Greifeneder, R., Müller, P., Stahlberg, D., Van den Bos, K., \& Bless, H. (2011b). Guiding trustful behavior: The role of accessible content and accessibility experiences. Journal of Behavioral Decision Making, 24(5), 498-514. http://dx.doi.org/10.1002/bdm.705 
*Greifeneder, R. \& Keller, J. (2012). Habitual self-regulatory orientation and ease-of-retrieval: Regulatory focus qualifies the impact of subjective experiences in judgment. Motiv Emot, 36(3), 338-348. http://dx.doi.org/10.1007/s11031-011-9251-8

*Haddock, G., Rothman, A.J., \& Schwarz, N. (1996). Are (some) reports of attitude strength context dependent? Canadian Journal of Behavioural Science, 28(4), 313-316. http://dx.doi.org/10.1037/0008-400X.28.4.313

*Haddock, G., Rothman, A.J., Reber, R., \& Schwarz, N. (1999). Forming judgments of attitude certainty, intensity, and importance: The role of subjective experiences. Personality and Social Psychology Bulletin, 25(7), 771-782.

http://dx.doi.org/10.1177/0146167299025007001

*Haddock, G. (2002). It's easy to like or dislike Tony Blair: Accessibility experiences and the favourability of attitude judgments. British Journal of Psychology, 93(2), 257-267. http://dx.doi.org/10.1348/000712602162571

*Haddock, G. (2004). Temporal self-appraisal and attributional focus. Journal of Experimental Social Psychology, 40(6), 787-794. http://dx.doi.org/10.1016/j.jesp.2004.04.004

*Hansen, J., \& Wänke, M. (2008). It's the difference that counts: Expectancy/experience discrepancy moderates the use of ease of retrieval in attitude judgments. Social Cognition, 26(4), 447-468. http://dx.doi.org/10.1521/soco.2008.26.4.447

Harris, C.R., Coburn, N., Rohrer, D., \& Pashler, H. (2013). Two Failures to Replicate HighPerformance-Goal Priming Effects. PLoS One, 8(8), 1-9. http://dx.doi.org/10.1371/journal.pone.0072467

Hedges, L.V., \& Olkin, I. (1985). Statistical methods for meta-analysis. Orlando, FL: Academic Press. 
Hermann, A.D., Leonardelli, G.J., \& Arkin, R.M. (2002). Self-doubt and self-esteem: A threat from within. Personality and Social Psychology Bulletin, 28(3), 395-408.

\section{http://dx.doi.org/10.1177/0146167202286010}

Hertwig, R., Hoffrage, U., \& the ABC Research Group (2013). Simple heuristics in a social world. New York: Oxford University Press.

Herzog, S. M., Hansen, J., \& Wänke, M. (2007). Temporal distance and ease of retrieval. Journal of Experimental Social Psychology, 43, 483-488. $\underline{\text { http://dx.doi.org/10.1016/j.jesp.2006.05.008 }}$

Higgins, E. T. (1989). Knowledge accessibility and activation: Subjectivity and suffering from unconscious sources. In J. S. Uleman \& J. A. Bargh (Eds.) Unintended Thought: The Limits of Awareness, Intention and control. New York: Guilford Press, pp. 75-123.

Higgins, E. T., Bargh, J. A., \& Lombardi, W. (1985). Nature of priming effects on categorization. Journal of Experimental Psychology: Learning, Memory, \& Cognition, 11, 59-69. https://doi.org/10.1037/0278-7393.11.1.59

Higgins, J.P.T., \& Thompson, S.G. (2002). Quantifying heterogeneity in a meta-analysis. Statistics in Medicine, 21(11), 1539-1558. http://dx.doi.org/10.1002/sim.1186

Hirt, E. R., Kardes, F.R., \& Markman, K.D. (2004). Activating a mental simulation mind-set through generation of alternatives: Implications for debiasing in related and unrelated domains. Journal of Experimental Social Psychology, 40, 374-383.

http://dx.doi.org/10.1016/j.jesp.2003.07.009

Huedo-Medina, T.B., Sanchez-Meca, J., Marin-Martinez, F., \& Botella, J. (2006). Assessing heterogeneity in meta-analysis: Q statistic or $\mathrm{I}^{\wedge} 2$ index? Psychological Methods, 11(2), 193-206. http://dx.doi.org/10.1037/1082-989X.11.2.193 
Hunter, J. E. \& Schmidt, F.L. (2004). Methods of meta-analysis: Correcting error and bias in research findings $\left(2^{\text {nd }}\right.$ ed). Thousand Oaks, CA: Sage Publications, Inc.

Hutchinson, J. W., Kamakura, W. \& Lynch, J. G. (2000). Unobserved heterogeneity as an alternative explanation for 'reversal' effects in behavioral research. Journal of Consumer Research, 27, 324-344. http://dx.doi.org/10.1086/317588

*Ijzerman, H., \& Semin, G.R. (2010). Temperature perceptions as a ground for social proximity. Journal of Experimental Social Psychology, 46(6), 867-873. http://dx.doi.org/10.1016/j.jesp.2010.07.015

Jacoby, L. L., \& Dallas, M. (1981). On the Relationship Between Autobiographical Memory and Perceptual Learning. Journal of Experimental Psychology: General, 110 (3), 306-340. http://dx.doi.org/10.1037/0096-3445.110.3.306

Jacoby, L. L., Kelley, C. M., \& Dywan, J. (1989). Memory Attributions.

*Janiszewski, C., Lichtenstein, D.R., \& Belyavsky, J. (2008). Judgments about judgments: The dissociation of consideration price and transaction commitment judgments. Journal of Experimental Psychology: Applied, 14(2), 151-164. http://dx.doi.org/10.1037/1076898x.14.2.151

*Janssen, J., Müller, P.A., \& Greifeneder, R. (2011). Cognitive processes in procedural justice judgments: The role of ease-of-retrieval, uncertainty, and experience. Journal of Organizational Behavior, 32(5), 726-750. http://dx.doi.org/10.1002/job.700

Johnson, B. T. \& Eagly, A.H. (2000). Quantitative synthesis of social psychological research. In H.T. Reis and C.M. Judd (Eds.), Handbook of research methods in social and personality psychology (496-528). London, UK: Cambridge University Press. 
Johnson, B.T., \& Eagly, A.H. (2014). Meta-analysis of social-personality psychological research. In H.T. Reis \& C.M. Judd (Eds.), Handbook of research methods in social and personality psychology ( $2^{\text {nd }}$ ed.) (675-707). London, UK: Cambridge University Press.

Johnson, E. J., \& Payne, J. W. (1985). Effort and accuracy in choice. Management Science, 31 (4), 395-414. https://doi.org/10.1287/mnsc.31.4.395

Johnston, W. A., Dark, V. J., \& Jacoby, L. L. (1985). Perceptual Fluency and Recognition Judgments. Journal of Experimental Psychology: Learning, Memory, and Cognition, 11 (1), 3-11. http://dx.doi.org/10.1037/0278-7393.11.1.3

*Kadous, K., Krische, S.D., \& Sedor, L.M. (2005). Using counter-explanation to limit analysts' forecast optimism. The Accounting Review, 81(2), 377-397. http://dx.doi.org/10.2308/accr.2006.81.2.377

Kahneman, D., \& Frederick, S. (2005). A Model of Heuristic Judgment. In K. J. Holyoak and R. G. Morrison (Eds.), The Cambridge handbook of thinking and reasoning, 267-293.

Kahneman, D. \& Tversky, A. (1979). Prospect Theory: An Analysis of Decision under Risk. Econometrica, 47 (2), 263-91. https://doi.org/10.2307/1914185

Keeney, R. L., \& Raiffa, H. (1993). Decisions with Multiple Objectives: Preferences and Value Tradeoffs. Cambridge University Press.

*Keller, J., \& Bless, H. (2005). When negative expectancies turn into negative performance: The role of ease of retrieval. Journal of Experimental Social Psychology, 41(5), 535-541. $\underline{\text { http://dx.doi.org/10.1016/j.jesp.2004.09.002 }}$

*Keller, J., \& Bless, H. (2009). Predicting future affective states: How ease of retrieval and faith in intuition moderate the impact of activated content. European Journal of Social Psychology, 39(3), 467-476. http://dx.doi.org/10.1002/ejsp.586 
*Kennedy, L.A. (2008). Looking at the past with a whole new perspective: The influence of visual perspective on hindsight bias (Doctoral Dissertation). Retrieved from Proquest Dissertations and Theses.

Kiernan, K., Tao, J., \& Gibbs, P. (2012). Tips and Strategies for Mixed Modeling with SAS/STAT Procedures. SAS Global Forum 2012, 1-18.

Kivetz, R., \& Zheng, Y. (2006). Determinants of justification and self-control. Journal of Experimental Psychology: General, 135(4), 572-587. http://dx.doi.org/10.1037/0096-

\section{$\underline{3445.135 .4 .572}$}

*Kühnen, U. (2010). Manipulation checks as manipulation: Another look at the ease-of-retrieval heuristic. Personality and Social Psychology Bulletin, 36(1), 47-58. http://dx.doi.org/10.1177/0146167209346746

*Kunstman, J.W., Plant, E.A., Zielaskowski, K., \& LaCosse, J. (2013). Feeling in with the outgroup: Outgroup acceptance and the internalization of the motivation to respond without prejudice. Journal of Personality and Social Psychology, 105(3), 443-457. http://dx.doi.org/10.1037/a0033082

LaBar, K.S., R. Cabeza. 2006. Cognitive neuroscience of emotional memory. Nature Review of Neuroscience, 7(1), 54-64. http://dx.doi.org/10.1038/nrn1825

*Laham, S.M. (2013). Ease of retrieval and the moral circle. Social Psychology, 44(1), 33-36. http://dx.doi.org/10.1027/1864-9335/a000099

*Lai, M., \& Kuo, C. (2007). Preventing piracy use intention by rectifying self-positivity bias. Social Behavior and Personality, 35(7), 961-974. http://dx.doi.org/10.2224/sbp.2007.35.7.961 
*Lee, L., Amir, O., \& Ariely, D. (2009). In search of homo economicus: Cognitive noise and the role of emotion in preference consistency. Journal of Consumer Research, 36(2), 173187. http://dx.doi.org/10.1086/597160

*Lee, S.J. (2005). Balancing acts: Possible selves and the transition from welfare to work (Doctoral Dissertation). Retrieved from Proquest Dissertations and Theses.

*Lemay, E.P., Clark, M.S., \& Feeney, B.C. (2007). Projection of responsiveness to needs and the construction of satisfying communal relationships. Journal of Personality and Social Psychology, 92(5), 834-853. http://dx.doi.org/10.1037/0022-3514.92.5.834

Light, R.J., \& Pillemar, D. B. (1984). Summing Up: The Science of Reviewing Research. Cambridge: Harvard University Press.

*Ling, C. Y. (2009). Understanding optimism: the antecedents and consequences of anticipatory purchase (Doctoral Dissertation). Retrieved from Proquest Dissertations and Theses.

Lipsey, M. W. \& Wilson, D.B. (2001). Practical meta-analysis. London, UK: SAGE.

Littell, R.C., Milliken, G.A., Stroup, W.W., Wolfinger, R.D., \& Schabenberger, O. (2006). SAS for mixed models. Cary, NC: SAS Institute Inc.

Lord, C. G., Ross, L., \& Lepper, M. R. (1979). Biased Assimilation and Attitude Polarization: The Effects of Prior Theories on Subsequently Considered Evidence. Journal of Personality and Social Psychology, 37 (11), 2098-2109. http://dx.doi.org/10.1037/0022$\underline{3514.37 .11 .2098}$

MacKinnon, D.P., Fairchild, A.J., \& Fritz, M.S. (2007). Mediation analysis. Annual Review of Psychology, 58(1), 593-614. http://dx.doi.org/10.1146/annurev.psych.58.110405.085542 
MacKinnon, D.P. \& Pirlott, A. G. (2015). Statistical approaches for enhancing causal interpretation of the $\mathrm{m}$ to $\mathrm{y}$ relation in mediation analysis. Personality and Social Psychology Review, 19(1), 30-43. http://dx.doi.org/10.1177/1088868314542878

*Menon, G., \& Raghubir, P. (2003). Ease-of-retrieval as an automatic input in judgments: A mere-accessibility framework? Journal of Consumer Research, 30(2), 230-243. http://dx.doi.org/10.1086/376804

*Merckelbach, H., Wiers, R., Horselenberg, R., \& Wessel, I. (2001). Effects of retrieving childhood events on metamemory judgments depend on the questions you ask. British Journal of Clinical Psychology, 40(2), 215-220.

http://dx.doi.org/10.1348/014466501163553

Milligan, G. (1980). An examination of the effect of six types of error perturbation on fifteen clustering algorithms. Psychometrika, 45(3), 325 -342. http://dx.doi.org/10.1007/BF02293907

*Min, K.S., \& Arkes, H.R. (2012). When is difficult planning good planning? The effects of scenario-based planning on optimistic prediction bias. Journal of Applied Social Psychology, 42(11), 2701-2729. http://dx.doi.org/10.1111/j.1559-1816.2012.00958.x

Mooneyham, B. W., Franklin, M. S., Mrazek, M. D., \& Schooler, J. W. (2012). Modernizing Science: Comments on Nosek and Bar-Anan (2012). Psychological Inquiry: An International Journal for the Advancement of Psychological Theory, 23 (3), 281-4. https://doi.org/10.1080/1047840X.2012.705246

*Müller, P.A., Greifeneder, R., Stahlberg, D., Van Den Bos, K., \& Bless, H. (2010). Shaping cooperation behavior: The role of accessibility experiences and uncertainty. European Journal of Social Psychology, 40(1), 178-187. 
*Nestler, S. (2010). Belief perseverance: The role of accessible content and accessibility experiences. Social Psychology, 41(1), 35-41. http://dx.doi.org/10.1027/1864$\underline{9335 / \mathrm{a} 000006}$

Nieuwenstein, M. R., Wierenga, T., Morey, R. D., Wicherts, J.M., Blom, T.N., Wagenmakers, E., \& van Rijn, H. (2015). On making the right choice: A meta-analysis and large-scale replication attempt of the unconscious thought advantage. Judgment and Decision Making, 10(1), 1-17.

*Novemsky, N., Dhar, R., Schwarz, N., \& Simonson, I. (2007). Preference fluency in choice. Journal of Marketing Research, 44(3), 347-356. http://dx.doi.org/10.1509/jmkr.44.3.347

*O'Brien, E. (2012). Ease-of-Retrieval. Unpublished raw data.

*O'Brien, E. (2013). Easy to retrieve but hard to believe: Metacognitive discounting of the unpleasantly possible. Psychological Science, 24(6), 844-851. http://dx.doi.org/10.1177/0956797612461359

Ofir, C. (2000). Ease of recall vs. recalled evidence in judgment: Experts vs. laymen. Organizational Behavior and Human Decision Processes, 81(1), 28-42. http://dx.doi.org/10.1006/obhd.1999.2864

*Ofir, C., Raghubir, P., Brosh, G., Monroe, K.B., \& Heiman, A. (2008). Memory-based store price judgments: The role of knowledge and shopping experience. Journal of Retailing, 84(4), 414-423. http://dx.doi.org/10.1016/j.jretai.2008.08.001

Oppenheimer, D. M. (2006). Consequences of Erudite Vernacular Utilized Irrespective of Necessity: Problems with Using Long Words Needlessly. Applied Cognitive Psychology, 20, 139-156. https://doi.org/10.1002/acp.1178 
*Oyserman, D., Fryberg, S.A., \& Yoder, N. (2007). Identity-based motivation and health. Journal of Personality and Social Psychology, 93(6), 1011-1027. http://dx.doi.org/10.1037/0022-3514.93.6.1011

*Pahl, S., \& Eiser, J.R. (2007). How malleable is comparative self-positivity? The effect of manipulating judgemental focus and accessibility. European Journal of Social Psychology, 37(4), 617-627. http://dx.doi.org/10.1002/ejsp.372

Palmer, T. M., Peters, J. L., Sutton, A. J., \& Moreno, S. G. (2008). Contour-enhanced funnel plots for meta-analysis. The Stata Journal, 8 (2), 242-254.

*Park, S. (2004). Essays on Retrieval Ease- versus Content-based Judgments (Doctoral Dissertation). Retrieved from Proquest Dissertations and Theses.

*Park, S. H. (2009). Prediction Processes in Intergroup Interaction (Doctoral Dissertation). Retrieved from Proquest Dissertations and Theses.

Payne, J. W., Bettman, J. R., \& Johnson, E. J. (1993). The Adaptive Decision Maker. Cambridge: Cambridge University Press.

Pearl, J. (2014). A short note on the virtues of graphical tools. Technical Report R-433, $<$ http://ftp.cs.ucla.edu/pub/stat ser/r433.pdf $>$, Department of Computer Science, University of California, Los Angeles, CA.

Pelham, B. W., Sumarta, T. T., \& Myaskovsky, L. (1994). The Easy Path from Many to Much: The Numerosity Heuristic. Cognitive Psychology, 26, 103-133. http://dx.doi.org/10.1006/cogp.1994.1004

Peters, J. L., Sutton, A. J., Jones, D. R., Abrams, K. R., \& Rushton, L. (2008). Contour-enhanced meta-analysis funnel plots help distinguish publication bias from other causes of asymmetry. Journal of Clinical Epidemiology, 61 (10), 991-996. 
Petty, R. E., Briñol, P., Tormala, Z. L., \& Wegener, D. T. (2007). The Role of Meta-Cognition in Social Judgment. In E.T. Higgins and A. Kruglanski (Eds.) Social Psychology: Handbook of basic principles (2 ${ }^{\text {nd }}$ ed.), 254-284.

Petty, R. E., \& Cacioppo, J. T. (1984). The effects of involvement on response to argument quantity and quality: Central and peripheral routes to persuasion. Journal of Personality and Social Psychology, 46, 69-81. https://doi.org/10.1037/0022-3514.46.1.69

Petty, R. E., \& Cacioppo, J. T. (1996). Attitudes and persuasion: Classic and contemporary approaches. Boulder, CO: Westview Press.

*Petrocelli, J.V., \& Dowd, K. (2009). Ease of counterfactual thought generation moderates the relationship between need for cognition and punitive responses to crime. Personality and Social Psychology Bulletin, 35(9), 1179-1192. http://dx.doi.org/10.1177/0146167209337164

Pham, M. T. (1998). Representativeness, Relevance, and the Use of Feelings in Decision Making. Journal of Consumer Research, 25(2), 144-159. https://doi.org/10.1086/209532

Pham, M. T. (2004). The Logic of Feeling. Journal of Consumer Psychology, 14(4), 360-369. https://doi.org/10.1207/s15327663jcp1404 5

*Pham, M.T., Lee, L., \& Stephen, A.T. (2012). Feeling the future: The emotional oracle effect. Journal of Consumer Research, 39(3), 461-477. http://dx.doi.org/10.1086/663823

*Pocheptsova, A., Labroo, A.A., \& Dhar, R. (2010). Making products feel special: When metacognitive difficulty enhances evaluation. Journal of Marketing Research, 47(6), 1059-1069. http://dx.doi.org/10.1509/jmkr.47.6.1059 
Podsakoff, P.M., MacKenzie, S.B., \& Podsakoff, N.P. (2012). Source of method bias in social science research and recommendations on how to control it. Annual Review of Psychology, 65, 539-569. http://dx.doi.org/10.1146/annurev-psych-120710-100452

Preacher, K. J. \& Kelley, K. (2011). Effect size measures for mediation models: Quantitative strategies for communicating indirect effects. Psychological Methods, 16(2), 93-115. http://dx.doi.org/10.1037/a0022658

*Preston, J., \& Epley, N. (2005). Explanations versus applications: The explanatory power of valuable beliefs. Psychological Science, 16(10), 826-832. http://dx.doi.org/10.1111/j.1467-9280.2005.01621.x

*Raghubir, P. \& Menon, G. (1998). AIDS and me, never the twain shall meet: The effects of information accessibility on judgments of risk and advertising effectiveness. Journal of Consumer Research, 25(June), 52-63. http://dx.doi.org/10.1086/209526

Raghubir, P., \& Menon, G. (2001). Framing effects in risk perceptions of aids. Marketing Letters, 12(2), 145-155. http://dx.doi.org/10.1023/A:1011165019311

*Raghubir, P. \& Menon, G. (2005). When and why is ease of retrieval informative? Memory \& Cognition, 33(5), 821-832. http://dx.doi.org/10.3758/BF03193077

*Rai, T.S., \& Holyoak, K. J. (2010). Moral principles or consumer preferences? Alternative framings of the trolley problem. Cognitive Science, 34(2), 311-321. http://dx.doi.org/10.1111/j.1551-6709.2009.01088.x

Raudenbush, S.W., \& Bryk, A.S. (2002). Hierarchical Linear Models (2nd ed.). Thousand Oaks, CA: Sage Publications.

*Redden, J.P., \& Galak, J. (2012). The subjective sense of feeling satiated. Journal of Experimental Psychology: General, 142(1), 209-217. http://dx.doi.org/10.1037/a0028896 
*Roese, N.J., \& Summerville, A. (2005). What we regret most... and why. Personality and Social Psychology Bulletin, 31(9), 1273-1285. http://dx.doi.org/10.1177/0146167205274693

Rohrer, D., Pashler, H., \& Harris, C. R. (2015). Do subtle reminders of money change people's political views? Journal of Experimental Psychology: General, 144 (4), e73-85. https://doi.org/10.1037/xge0000058

Rosenberg, M. S. (2005). The file-drawer problem revisited: A general weighted method for calculating fail-safe numbers in meta-analysis. Evolution, 59(2), 464-468. http://dx.doi.org/10.1111/j.0014-3820.2005.tb01004.x

Rosenthal, R. (1979). The file drawer problem and tolerance for null results. Psychological Bulletin, 86(3), 638-641. http://dx.doi.org/10.1037/0033-2909.86.3.638

Rosenthal, R. (1991). Meta-analytic procedures for social research. Newbury Park, CA: Sage. Rosenthal, R. \& DiMatteo, M. R. (2001). Meta-analysis: recent developments in quantitative methods for literature reviews. Annual Review of Psychology, 52, 59-82. http://dx.doi.org/10.1146/annurev.psych.52.1.59

Rosenthal, R. \& Rosnow, R.L. (2008). Essentials of behavioral research ( $3^{\text {rd }}$ ed.). Boston, MA: McGraw Hill.

Rosenthal, R., Rosnow, R. L., \& Rubin, D. B. (2000). Contrasts and Effect Sizes in Behavioral Research: A Correlational Approach. Cambridge: Cambridge University Press.

*Rothman, A. J., \& Hardin, C.D. (1997). Differential use of the availability heuristic in social judgment. Personality and Social Psychology Bulletin, 23(2), 123-138. http://dx.doi.org/10.1177/0146167297232002

*Rothman, A. J., \& Schwarz, N. (1998). Constructing perceptions of vulnerability: Personal relevance and the use of experiential information in health judgments. Personality and 
Social Psychology Bulletin, 24(10), 1053-1064.

http://dx.doi.org/10.1177/01461672982410003

*Ruder, M., \& Bless, H. (2003). Mood and the reliance on the ease of retrieval heuristic. Journal of Personality and Social Psychology, 85(1), 20-32. http://dx.doi.org/10.1037/0022$\underline{3514.85 .1 .20}$

Sackett, A.M. (2006). Reasoned optimism: an "intuitive functionalist" account of personal predictions (Doctoral Dissertation). Retrieved from Proquest Dissertations and Theses.

*Sanna, L.J., Chang, E.C., \& Carter, S.E. (2004). All our troubles seem so far away: Temporal pattern to accessible alternatives and retrospective team appraisals. Personality and Social Psychology Bulletin, 30(10), 1359-1371.

http://dx.doi.org/10.1177/0146167204263784

*Sanna, L.J., \& Schwarz, N. (2003). Debiasing the hindsight bias: The role of accessibility experiences and (mis)attributions. Journal of Experimental Social Psychology, 39(3), 287-295. http://dx.doi.org/10.1016/S0022-1031(02)00528-0

Sanna, L.J., \& Schwarz, N. (2004). Integrating temporal biases: The interplay of focal thoughts and accessibility experiences. Psychological Science, 15(7), 474-481. http://dx.doi.org/10.1111/j.0956-7976.2004.00704.x

*Sanna, L.J., Schwarz, N., \& Small, E.M. (2002a). Accessibility experiences and the hindsight bias: I knew it all along versus it could never have happened. Memory \& Cognition, 30(8), 1288-1296. http://dx.doi.org/10.3758/BF03213410

*Sanna, L. J., Schwarz, N., \& Stocker, S.L. (2002b). When debiasing backfires: Accessible content and accessibility experiences in debiasing hindsight. Journal of Experimental 
Psychology: Learning, Memory, and Cognition, 28(3), 497-502.

http://dx.doi.org/10.1037/0278-7393.28.3.497

*Sanna, L.J., Parks, C.D., Chang, E.C., \& Carter, S.E. (2005). The hourglass is half full or half empty: Temporal framing and the group planning fallacy. Group Dynamics: Theory, Research, and Practice, 9(3), 173-188. http://dx.doi.org/10.1037/1089-2699.9.3.173

*Scarnier, M.A. (2007). Parents' vicarious shame and guilt responses to children's wrong-doings (Doctoral Dissertation). Retrieved from Proquest Dissertations and Theses.

Scheibehenne, B., Greifeneder, R., \& Todd, P.M. (2010). Can there ever be too many options? A meta-analytic review of choice overload. Journal of Consumer Research, 37(3), 409-425. http://dx.doi.org/10.1086/651235

Schiffrin, R. M., \& Schneider, W. (1977). Controlled and Automatic Information Processing: II. Perceptual Learning, Automatic Attending, and a General Theory. Psychological Review, $84(2), 127-190$.

*Schlegel, R.J., Hicks, J.A., King, L.A., \& Arndt, J. (2011). Feeling like you know who you are: Perceived true self-knowledge and meaning in life. Personality and Social Psychology Bulletin, 37(6), 745-756. http://dx.doi.org/10.1177/0146167211400424

*Schlegel, R.J., Hicks, J.A., Davis, W.E., Hirsch, K.A., \& Smith, C.M. (2013). The dynamic interplay between perceived true self-knowledge and decision satisfaction. Journal of Personality and Social Psychology, 104(3), 542-558. http://dx.doi.org/10.1037/a0031183

Scholl, S. G., Greifeneder, R., \& Bless, H. (2014). When fluency signals truth: Prior successful reliance on fluency moderates the impact of fluency on truth judgments. Journal of Behavioral Decision Making, 27(3), 268-80. http://dx.doi.org/10.1002/bdm.1805 
Schooler, J.W. (2011). Unpublished results hide the decline effect. Nature, 470, 437. http://dx.doi.org/10.1038/470437a

*Schwarz, N., Bless, H., Strack, F., Klump, G., Rittenauer-Schatka, H., \& Simons, A. (1991). Ease of retrieval as information: Another look at the availability heuristic. Journal of Personality and Social Psychology, 61(2), 195-202. http://dx.doi.org/10.1037/0022-

\section{$\underline{3514.61 .2 .195}$}

Schwarz, N. (1998). Accessible content and accessibility experiences: The interplay of declarative and experiential information in judgment. Personality and Social Psychology Review, 2(2), 87-99. http://dx.doi.org/10.1207/s15327957pspr0202 2

Schwarz, N. (2004). Metacognitive experiences in consumer judgment and decision making. Journal of Consumer Psychology, 14(4), 332-348. http://dx.doi.org/10.1207/s15327663jep1404_2

Schwarz, N., \& Clore, G. L. (1983). Mood, Misattribution, and Judgments of Well-Being: Informative and Directive Functions of Affective States. Journal of Personality and Social Psychology, 45 (3), 513-523. http://dx.doi.org/10.1037/0022-3514.45.3.513

Schwarz, N., \& Clore, G. L. (1988). How Do I Feel About It? The Informative Function of Affective States. In K. Fiedler \& J. Forgas (Eds.), Affect, cognition, and social behavior: new evidence and integrative attempts, 44-62. Toronto: C. J. Hogrefe.

Schwarz, N. \& Clore, G.L. (2007). Feelings and phenomenal experiences. In A. Kruglanski and E.T. Higgins (Eds.) Social Psychology, Handbook of Basic Principles, 385-407.

Shafir, E. (2012). The behavioral foundations of public policy. Princeton, NJ: Princeton University Press. 
Shanks, D.R., Newell, B.R., Lee, E.H., Balakrishnan, D., Ekelund, L., Cenac, Z., ... Moore, C. (2013). Priming Intelligent Behavior: An Elusive Phenomenon. PLoS One, 8(4), e56515. http://dx.doi.org/10.1371/journal.pone.0056515

*Sharma, E., Mazar, N., Alter, A.L., \& Ariely, D. (2014). Financial deprivation selectively shifts moral standards and compromises moral decisions. Organizational Behavior and Human Decision Processes, 123, 90-100. http://dx.doi.org/10.1016/j.obhdp.2013.09.001

*Shockley, E.C. (2013). The case for existence biases (Doctoral Dissertation). Retrieved from Proquest Dissertations and Theses.

*Silvera, D.H., Kardes, F.R., Harvey, N., Cronley, M.L., \& Houghton, D.C. (2005). Contextual influence on omission neglect in the fault tree paradigm. Journal of Consumer Psychology, 15(2), 117-126. http://dx.doi.org/10.1207/s15327663jcp1502 4

Simmons, J.P., Nelson, L.D., \& Simonsohn, U. (2011). False-positive psychology: Undisclosed flexibility in data collection and analysis allow presenting anything as significant. Psychological Science, 22(11), 1359-1366. http://dx.doi.org/10.1177/0956797611417632

Simon, H. A. (1978). Prize Lecture: Rational Decision-Making in Business Organizations. Nobelprize.org.

*Simonsohn, U., Nelson, L.D., \& Simmons, J.P. (2011). Ease-of-Retrieval. Unpublished raw data.

*Sinclair, S., \& Carlsson, R. (2013). What will I be when I grow up? The impact of gender identity threat on adolescents' occupational preferences. Journal of Adolescence, 36(3), 465-474. http://dx.doi.org/10.1016/j.adolescence.2013.02.001 
*Sinha, J., \& Naykankuppam, D. (2013). Knowledge does not necessarily make the heart grow fonder: The moderating role of knowledge on accessibility experiences. Journal of Consumer Psychology, 23(1), 49-60. http://dx.doi.org/10.1016/j.jcps.2012.02.004

*Spielmann, S.S., MacDonald, G., \& Wilson, A.E. (2009). On the rebound: Focusing on someone new helps anxiously attached individuals let go of ex-partners. Personality and Social Psychology Bulletin, 35(10), 1382-1394. http://dx.doi.org/10.1177/0146167209341580

Stanley, T. D., \& Doucouliagos, H. (2014). Meta-regression approximations to reduce publication selection bias. Research Synthesis Methods, 5 (1), 60-78. http://dx.doi.org/10.1002/jrsm.1095

*Stephen, A.T., \& Pham, M.T. (2008). On feelings as a heuristic for making offers in ultimatum negotiations. Psychological Science, 19(10), 1051-1058. http://dx.doi.org/10.1111/j.1467-9280.2008.02198.x

*Stephens, M. (2003). Early detection of alzheimer's disease: The influences of the availability heuristic and person perception (Doctoral Dissertation). Retrieved from Proquest Dissertations and Theses.

Stepper, S., \& Strack, F. (1993). Proprioceptive determinants of emotional and nonemotional feelings. Journal of Personality and Social Psychology, 64 (2), 211-20. https://doi.org/10.1037/0022-3514.64.2.211

*Stocker, S.L. (2006). Accessibility experiences and perceived relationship superiority (Doctoral Dissertation). Retrieved from Proquest Dissertations and Theses. 
*Stone, J., \& Fernandez, N.C. (2011). When thinking about less failure causes more dissonance: The effect of elaboration and recall on behavior change following hypocrisy. Social Influence, 6(4), 199-211. http://dx.doi.org/10.1080/15534510.2011.618368

*Sussman, A.B., \& Alter, A.L. (2012). The exception is the rule: Underestimating and overspending on exceptional expenses. Journal of Consumer Research, 39(2), 800-814. http://dx.doi.org/10.1086/665833

Sutton, A.J. (2009). Publication bias. In J.C. Valentine, H. Cooper, \& L.V. Hedges (Eds.), The Handbook of Research Synthesis and Meta-Analysis (pgs. 435-52). New York, NY: Russell Sage Foundation.

Taylor, S. E. (1982). The availability bias in social perception and interaction. In D. Kahneman, P. Slovic, \& A. Tversky (Eds.), Judgment under uncertainty: Heuristics and biases. Cambridge: Cambridge University Press, pp. 190-200.

Terrin, N., Schmid, C. H., Lau, J., \& Olkin, O. (2003). Adjusting for publication bias in the presence of heterogeneity. Statistics in Medicine, 22(13), 2113-2126. http://dx.doi.org/10.1002/sim.1461

*Thorisdottir, H., \& Jost, J.T. (2011). Motivated close-mindedness mediates the effect of threat on political conservatism. Political Psychology, 32(5), 785-811. http://dx.doi.org/10.1111/j.1467-9221.2011.00840.x

Tiedens, L. Z., \& Linton, S. (2001). Judgment under emotional certainty and uncertainty: The effects of specific emotions on information processing. Journal of Personality and Social Psychology, 81(6), 973-988. http://dx.doi.org/10.1037/0022-3514.81.6.973

Todd, P.M., \& Gigerenzer, G. (2012). Ecological rationality: Intelligence in the world. New York, NY: Oxford University Press, Inc. 
*Tormala, Z. L., Petty, R.E., \& Briñol, P. (2002). Ease of retrieval effects in persuasion: A selfvalidation analysis. Personality and Social Psychology Bulletin, 28(12), 1700-1712. http://dx.doi.org/10.1177/014616702237651

*Tormala, Z.L., Falces, C., Briñol, P., \& Petty, R.E. (2007). Ease of retrieval effects in social judgment: The role of unrequested cognitions. Journal of Personality and Social Psychology, 93(2), 143-157. http://dx.doi.org/10.1037/0022-3514.93.2.143

*Tsai, C.I., \& McGill, A.L. (2011). No pain, no gain? How fluency and construal level affect consumer confidence. Journal of Consumer Research, 37(5), 807-821. http://dx.doi.org/10.1086/655855

*Tsai, C. I. \& Thomas, M. (2011), When does feeling of fluency matter? How abstract and concrete thinking influence fluency effects. Psychological Science, 22(3), 348-354. http://dx.doi.org/10.1177/0956797611398494

Tversky, A., \& Kahneman, D. (1973). Availability: A heuristic for judging frequency and probability. Cognitive Psychology, 5(2), 207-232. http://dx.doi.org/10.1016/0010$\underline{0285(73) 90033-9}$

Tversky, A., \& Kahneman, D. (1974). Judgment under uncertainty: Heuristics and biases. Science, 185(4157), 1124-1131. http://dx.doi.org/10.1126/science.185.4157.1124

*Tybout, A. M., Sternthal, B., Malaviya, P., Bakamitsos, G.A., \& Park, S. (2005). Information accessibility as a moderator of judgments: The role of content versus retrieval ease. Journal of Consumer Research, 32(1), 76-85. http://dx.doi.org/10.1086/426617

Unkelbach, C. (2006). The learned interpretation of cognitive fluency. Psychological Science, 17(4), 339-345. http://dx.doi.org/10.1111/j.1467-9280.2006.01708.x 
Unkelbach, C. (2007). Reversing the truth effect: Learning the interpretation of processing fluency in judgments of truth. Journal of Experimental Psychology: Learning, Memory, and Cognition, 33(1), 219-230. http://dx.doi.org/10.1037/0278-7393.33.1.219

*Unkelbach, C., \& Plessner, H. (2007). “Category-Split” Effects in judgments about sportswomen, sportsmen, and sports. Zeitschrift fur Sozialpsychologie, 38(2), 111-121. http://dx.doi.org/10.1024/0044-3514.38.2.111

*Vastfjall, D., Peters, E., \& Slovic, P. (2008). Affect, risk perception and future optimism after the tsunami disaster. Judgment and Decision Making, 3(1), 64-72.

Van den Bussche, E., Van den Noortgate, W., \& Reynvoet, B. (2009). Mechanisms of masked priming: a meta-analysis. Psychological Bulletin, 135(3), 452-477. http://dx.doi.org/10.1037/a0015329

*Vaughn, L.A. (1998). Expertise and use of experienced ease or difficulty of recall for social judgments (Doctoral Dissertation). Retrieved from Proquest Dissertations and Theses.

*Vaughn, L. A. (1999). Effects of uncertainty on use of the availability of heuristic for selfefficacy judgments. European Journal of Social Psychology, 29(2-3), 407-410. http://dx.doi.org/10.1002/(SICI)1099-0992(199903/05)29:2/3<407::AIDEJSP943>3.0.CO;2-3

*Vaughn, L.A., \& Weary, G. (2002). Roles of the availability of explanations, feelings of ease, and dysphoria in judgments about the future. Journal of Social and Clinical Psychology, 21(6), 686-704. http://dx.doi.org/10.1521/jscp.21.6.686.22794

Viechtbauer, W. (2010). Conducting Meta-Analyses in R with the metaphor Package. Journal of Statistical Software, 36 (3), 1-48. 
*Von Helversen, B., Gendolla, G.E., Winkielman, P., \& Schmidt, R.E. (2008). Exploring the hardship of ease: Subjective and objective effort in the ease-of-processing paradigm. Motivation and Emotion, 32(1), 1-10. http://dx.doi.org/10.1007/s11031-008-9080-6

Walton, G.M., \& Cohen, G.L. (2007). A question of belonging: Race, social fit, and achievement. Journal of Personality and Social Psychology, 92(1), 82-96. http://dx.doi.org/10.1037/0022-3514.92.1.82

Wänke, M. (2013). Almost everything you always wanted to know about ease-of-retrieval effects. In C. Unkelbach, \& R. Greifeneder (Eds.), The Experience of thinking: How the fluency of mental processes influences cognition and behavior (pp. 151-169). London, UK: Psychology Press.

*Wänke, M., Bless, H., \& Biller, B. (1996). Subjective experience versus content of information in the construction of attitude judgments. Personality and Social Psychology Bulletin, 22(11), 1105-1113. http://dx.doi.org/10.1177/01461672962211002

*Wänke, M., Bohner, G., \& Jurkowitsch, A. (1997). There are many reasons to drive a BMW: Does imagined ease of argument generation influence attitudes? Journal of Consumer Research, 24(2), 170-178. http://dx.doi.org/10.1086/209502

Wänke, M., \& Bless, H. (2000). The effects of subjective ease of retrieval on attitudinal judgments: The moderating role of processing motivation. Personality and Social Psychology Bulletin, 22, 1105-1113.

Wänke, M., Schwarz, N., \& Bless, H. (1995). The availability heuristic revisited: Experienced ease of retrieval in mundane frequency estimates. Acta Psychologica, 89, 83-90. http://dx.doi.org/10.1016/0001-6918(93)E0072-A 
*Weaver, J.R., Vandello, J.A., \& Bosson, J.K. (2013). Intrepid, imprudent, or impetuous? The effects of gender threats on men's financial decisions. Psychology of Men \& Masculinity, 14(2), 184-191. http://dx.doi.org/10.1037/a0027087

*Wehr, T. (2010). The phenomenology of exception times: Qualitative differences between problem-focussed and solution-focussed interventions. Applied Cognitive Psychology, $24(4), 467-480$.

*Weick, M., \& Guinote, A. (2008). When subjective experiences matter: Power increases reliance on the ease of retrieval. Journal of Personality and Social Psychology, 94(6), 956-70. http://dx.doi.org/10.1037/0022-3514.94.6.956

Whittlesea, B. W. A. (1993). Illusions of Familiarity. Journal of Experimental Psychology: Learning, Memory, and Cognition, 19 (6), 1235-1253. https://doi.org/10.1037/0278$\underline{7393.19 .6 .1235}$

*Winkielman, P., \& Schwarz, N. (2001). How pleasant was your childhood? Beliefs about memory shape inferences from experienced difficulty of recall. Psychological Science, 12(2), 176-179. http://dx.doi.org/10.1111/1467-9280.00330

*Winkielman, P., Schwarz, N., \& Belli, R. (1998). The role of ease of retrieval and attribution in memory judgments: Judging your memory as worse despite recalling more events. Psychological Science, 9(2), 124-126. http://dx.doi.org/10.1111/1467-9280.00022

*Woltin, K., Corneille, O., \& Yzerbyt, V. Y. (2014). Retrieving autobiographical memories influences judgments about others: The role of metacognitive experiences. Personality and Social Psychology Bulletin, 40(4), 526-539.

http://dx.doi.org/10.1177/0146167213519479 
*Wood, S. (2010). The comfort food fallacy: Avoiding old favorites in times of change. Journal of Consumer Research, 36(6), 950-963. http://dx.doi.org/10.1086/644749

*Yahalom, N., \& Schul, Y. (2013). How thinking about the other affects our reliance on cognitive feelings of ease and effort: Immediate discounting and delayed utilization. Social Cognition, 31(1), 31-56. http://dx.doi.org/10.1521/soco.2013.31.1.31

*Yeager, D. S., \& Krosnick, J. (2014). Ease-of-Retrieval. Unpublished raw data.

*Yoke, K.L. (2013). Effects of directed thinking about role models on attitudes toward math and science (Doctoral Dissertation). Retrieved from Proquest Dissertations and Theses.

Zajonc, R. B., \& Markus, H. (1982). Affective and Cognitive Factors in Preferences. Journal of Consumer Research, 9 (2), 123-31. https://doi.org/10.1086/208905

*Zauberman, G., Ratner, R.K., \& Kim, B.K. (2009). Memories as assets: Strategic memory protection in choice over time. Journal of Consumer Research, 35(5), 715-728. http://dx.doi.org/10.1086/592943

Zhao, X., Lynch, J.G., \& Chen, Q. (2010). Reconsidering Baron and Kenny: Myths and truths about mediation analysis. Journal of Consumer Research, 37(2), 197-206. http://dx.doi.org/10.1086/651257

*Zhao, M., Hoeffler, S., \& Dahl, D.W. (2012). Imagination difficulty and new product evaluation. Journal of Product Innovation Management, 29(S1), 76-90. http://dx.doi.org/10.1111/j.1540-5885.2012.00951.x 
Table 1.

Example cases of proximal and distal effect sizes.

\section{Proximal}

Aarts and Dijksterhuis 1999

Biswas et al. 2012

Haddock 2002

Keller and Bless 2009

Novemsky et al. 2007

Pocheptsova et al. 2010

Schwarz et al. 1991

Tsai and Thomas 2011

Alter and Balcetis 2011

Bartels and Urminsky 2011

Gawronski and Bodenhausen 2005

Muller et al. 2011

Pham et al. 2012

Schlegel et al. 2011

Sussman and Alter 2012
People recall instances of biking, then they make judgments about how frequently they bike.

Participants come up with reasons why a car may have starting problems; participants judge likelihood that a 5-year old used Volkswagen car might fail to start anytime within the next 6 months.

People recall reasons to like/dislike Tony Blair, then they make judgments about Tony Blair.

Participants think of few or many things in their life impacted by having a right leg amputated; perceived negative affect duration was the DV.

People imagine having to generate reasons for choosing a given product, then they make a choice of product.

People think of occasions for going to a restaurant; willingness-to-pay for dinner in that restaurant is the DV.

People recall assertive/unassertive instances; they make judgments of assertiveness.

People imagine reasons to donate or not, then they decide whether/how much to donate.

\section{Distal}

People consider positive or negative elements of NYC, then they rate the felt distance to NYC. The attitude towards NYC is meant to be related to its subjective distance.

People consider how hard it would be to generate reasons their identity would remain stable, then their discount factor is assessed. Feelings of connectedness to the future identity is argued to be related to discount factor.

People come up with exemplars of minorities they like, then they complete measures of implicit stereotyping (RT as dependent measure). Accessibility is argued to be related to our attitudes.

Participants come up with few or many unfair things about a negotiation game; the main DV is cooperation in the negotiation game. There is supposed to be a linkage between perceived unfairness and cooperation.

People recall times they were correct in trusting their feelings, then make predictions about some outcome. Trust in feelings is argued to be related to prediction accuracy.

People come up with descriptors of themselves, then judge meaning in life. Knowing oneself is argued to be related to meaning in life.

Participants think of items they had bought from a product category; willingnessto- pay for items from that category (based on subsequent questions) was the DV. Perceived category size is related to perceptions of being extraordinary and thus willingness-to-pay. 
Table 2.

Descriptive Statistics of Ease-of-Retrieval Effect Sizes.

\begin{tabular}{|c|c|c|}
\hline Variable & Proximal $(\mathrm{N}=454)$ & Distal $(\mathrm{N}=128)$ \\
\hline \multicolumn{3}{|l|}{ Year } \\
\hline$M(\mathrm{SD})$ & $2006(5.25)$ & $2009(3.33)$ \\
\hline Median & 2007 & 2010 \\
\hline \multicolumn{3}{|l|}{ Country } \\
\hline United States (\%) & $254(55.9)$ & $97(75.8)$ \\
\hline Non-US (\%) & $200(44.1)$ & $31(24.2)$ \\
\hline \multicolumn{3}{|l|}{ Publication Type } \\
\hline Journal Article (\%) & $350(77.1)$ & $101(78.9)$ \\
\hline Unpublished (\%) & $104(22.9)$ & $27(21.1)$ \\
\hline \multicolumn{3}{|l|}{ Paradigm } \\
\hline Standard $(\%)$ & $298(65.6)$ & $92(71.9)$ \\
\hline Moderated (\%) & $156(34.4)$ & $36(28.1)$ \\
\hline \multicolumn{3}{|l|}{ Misattribution } \\
\hline Present (\%) & $22(4.8)$ & $2(1.6)$ \\
\hline Absent (\%) & $432(95.2)$ & $126(98.4)$ \\
\hline \multicolumn{3}{|l|}{ Target of Retrieval } \\
\hline Self $(\%)$ & $160(35.2)$ & $74(57.8)$ \\
\hline Not Self $(\%)$ & $294(64.8)$ & $54(42.2)$ \\
\hline \multicolumn{3}{|l|}{ Target of Judgment } \\
\hline Self $(\%)$ & $256(56.4)$ & $103(80.5)$ \\
\hline Not Self $(\%)$ & $198(43.6)$ & $25(19.5)$ \\
\hline \multicolumn{3}{|l|}{ Polarized Attitude } \\
\hline Yes $(\%)$ & $22(4.8)$ & $0(0)$ \\
\hline No $(\%)$ & $432(95.2)$ & $128(100)$ \\
\hline \multicolumn{3}{|l|}{ Arguments } \\
\hline$M$, Few (SD) [Median] & $2.50(1.11)[2]$ & $2.44(0.99)[2]$ \\
\hline$M$, Many (SD) [Median] & $8.60(2.95)[8]$ & $9.47(3.08)[10]$ \\
\hline \multicolumn{3}{|l|}{ Measure of Subjective Ease } \\
\hline Before DV (\%) & $106(23.3)$ & $32(25)$ \\
\hline After DV (\%) & $290(63.9)$ & $42(32.8)$ \\
\hline None $(\%)$ & $58(12.8)$ & $54(42.2)$ \\
\hline \multicolumn{3}{|l|}{ DV Type } \\
\hline Attitude (\%) & $369(81.3)$ & $70(54.7)$ \\
\hline Non-Attitude $(\%)$ & $85(18.7)$ & $58(45.3)$ \\
\hline Median, Number of Ease Items & 1 & 1 \\
\hline Median, Number of Measures & 2 & 2 \\
\hline
\end{tabular}


Table 3.

Overall Effect Sizes [95\% CIs] for the Ease-of-Retrieval Effect.

\begin{tabular}{|c|c|c|c|}
\hline Effect Size & $\begin{array}{c}\text { Combined } \\
\text { Standard/Moderated } \\
\end{array}$ & $\begin{array}{l}\text { Standard } \\
\text { Paradigm }\end{array}$ & $\begin{array}{c}\text { Moderated } \\
\text { Paradigm }\end{array}$ \\
\hline & \multicolumn{3}{|c|}{ Total Effect of $X$ on $Y(c)$ - Proximal } \\
\hline$c$ (all data) & $.121[.094, .149]$ & $.253[.224, .281]$ & $-.178[-.215,-.140]$ \\
\hline \multirow[t]{2}{*}{$c$ (mediation triplets) } & $.109[.073, .145]$ & $.223[.184, .262]$ & $-.166[-.230,-.100]$ \\
\hline & \multicolumn{3}{|c|}{ Direct $\left(c^{\prime}\right)$ and Indirect $(a x b)$ Effects of $X$ on $Y$ - Proximal } \\
\hline$c^{\prime}$ (mediation triplets) & $.019[-.105, .053]$ & $.105[.064, .145]$ & $-.205[-.273,-.137]$ \\
\hline$a \times b$ (mediation triplets) & $.096[.060, .132]$ & $.114[.074, .154]$ & $.042[.010, .073]$ \\
\hline \multicolumn{4}{|c|}{ Total Effect of $X$ on $Y(c)-$ Distal } \\
\hline$c$ (all data) & $.164[.128, .201]$ & $.264[.221, .307]$ & $-.082[-.158,-.005]$ \\
\hline \multirow[t]{2}{*}{$c$ (mediation triplets) } & $.154[.085, .221]$ & $.308[.219, .393]$ & $-.125[-.231,-.015]$ \\
\hline & \multicolumn{3}{|c|}{ Direct $\left(c^{\prime}\right)$ and Indirect $(a \times b)$ Effects of $X$ on $Y-$ Distal } \\
\hline$c^{\prime}$ (mediation triplets) & $.112[.034, .191]$ & $.208[.144, .272]$ & $-.121[-.232,-.010]$ \\
\hline$a \times b$ (mediation triplets) & $.034[-.020, .087]$ & $.046[-.029, .121]$ & $.002[-.034, .037]$ \\
\hline
\end{tabular}


Table 4.

Moderator Means and Multiple Regression Results for the Ease-of-Retrieval Effect for proximal.

\begin{tabular}{|c|c|c|c|c|c|c|c|c|c|}
\hline \multirow[b]{2}{*}{ Moderator } & \multirow[b]{2}{*}{ Level } & \multicolumn{5}{|c|}{ Combined Standard and Moderated Paradigm Data } & \multicolumn{3}{|c|}{ Standard Paradigm Data Only } \\
\hline & & $\begin{array}{r}\text { Number of } \\
\text { Effect } \\
\text { Sizes } \\
\end{array}$ & $\begin{array}{r}\text { Mean Effect Size } \\
\text { (S.E. })^{1}\end{array}$ & & $\begin{array}{l}\text { Regression } \\
\text { Coefficient }^{2}\end{array}$ & & $\begin{array}{r}\text { Number of } \\
\text { Effect } \\
\text { Sizes } \\
\end{array}$ & $\begin{array}{r}\text { Mean Effect Size } \\
\text { (S.E. })^{1}\end{array}$ & $\begin{array}{l}\text { Regression } \\
\text { Coefficient }^{2}\end{array}$ \\
\hline \multicolumn{10}{|c|}{ Salience Moderators } \\
\hline Range & & 454 & $.009(.013)$ & & .015 & & 298 & $-.005(.012)$ & .012 \\
\hline \multirow[t]{2}{*}{ Attention } & Before DV $(+1)$ & 106 & $.114(.023)$ & & -.002 & & 73 & $.245(.019)$ & -.005 \\
\hline & After DV (-1) & 348 & $.124(.015)$ & & & & 225 & $.255(.016)$ & \\
\hline \multirow[t]{2}{*}{ Polarized Attitude } & Yes $(+1)$ & 22 & $-.140(.056)$ & $* * *$ & -.064 & $* * *$ & --- & --- & --- \\
\hline & No $(-1)$ & 432 & $.134(.014)$ & & & & --- & --- & \\
\hline \multicolumn{10}{|c|}{ Inference Moderators } \\
\hline \multirow{3}{*}{$\begin{array}{l}\text { Processing } \\
\text { Motivation } \\
\text { (depth) }\end{array}$} & High $(+1)$ & 12 & $-.184(.076)$ & $* * *$ & -.034 & $* *$ & --- & --- & --- \\
\hline & No manipulation (0) & 417 & $.128(.014)$ & & & & --- & --- & \\
\hline & Low $(-1)$ & 25 & $.150(.057)$ & & & & --- & --- & \\
\hline \multirow{3}{*}{$\begin{array}{l}\text { Processing } \\
\text { Motivation } \\
\text { (involvement) }\end{array}$} & $\operatorname{High}(+1)$ & 26 & $.178(.057)$ & $\wedge$ & .030 & $* *$ & --- & --- & --- \\
\hline & No manipulation (0) & 404 & $.124(.015)$ & & & & --- & --- & \\
\hline & Low $(-1)$ & 24 & $.008(.061)$ & & & & --- & --- & \\
\hline \multirow{2}{*}{$\begin{array}{l}\text { Representativeness } \\
\text { (retrieval target) }\end{array}$} & Self $(+1)$ & 160 & $.108(.022)$ & & -019 & & 114 & $.196(.021) * * *$ & $-.030 *$ \\
\hline & Not-Self $(-1)$ & 294 & $.130(.018)$ & & & & 184 & $.286(.017)$ & \\
\hline \multirow{2}{*}{$\begin{array}{l}\text { Representativeness } \\
\text { (misattribution) }\end{array}$} & Present $(+1)$ & 22 & $-.246(.065)$ & $* * *$ & -.092 & $* * *$ & --- & --- & --- \\
\hline & Absent (-1) & 432 & $.136(.014)$ & & & & --- & --- & \\
\hline \multirow{2}{*}{$\begin{array}{l}\text { Relevance } \\
\text { (judgment task) }\end{array}$} & Self $(+1)$ & 256 & $.123(.018)$ & & -.001 & & 180 & $.221(.018) * * *$ & $-.028 *$ \\
\hline & Not-Self $(-1)$ & 198 & $.121(.021)$ & & & & 118 & $.298(.021)$ & \\
\hline \multirow{3}{*}{$\begin{array}{l}\text { Relevance } \\
\text { (disposition) }\end{array}$} & High $(+1)$ & 15 & $.226(.076)$ & $* * *$ & .045 & $* * *$ & --- & --- & --- \\
\hline & No manipulation (0) & 426 & $.128(.014)$ & & & & --- & --- & \\
\hline & Low $(-1)$ & 13 & $-.194(.083)$ & & & & --- & --- & \\
\hline
\end{tabular}

Note: ${ }^{\wedge} p<.10 * p<.05 * * p<.01 * * * p<.001$.

Sample means and standard errors were computed separately for each level, except for continuous variables for which bivariate regression slopes and associated standard errors are reported. Bivariate tests were used to determine statistical significance levels.

${ }^{2}$ Coefficients are based on a multiple regression that used a two-level model with random intercepts for papers. All variables were standardized. VIFs were all below 10 and the maximum condition index was below 30 . 
Table 4 (continued).

Moderator Means and Multiple Regression Results

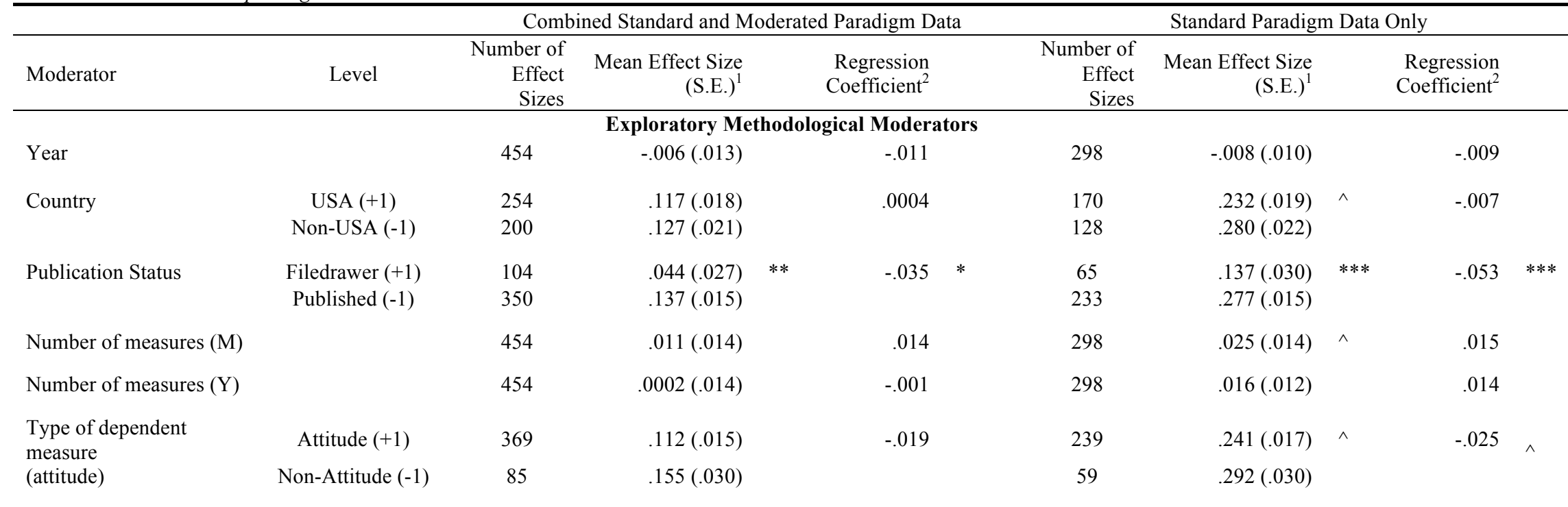

Note: ^ $p<.10 * p<.05 * * p<.01 * * * p<.001$.

${ }^{1}$ Sample means and standard errors were computed separately for each level, except for continuous variables for which bivariate regression slopes and associated standard errors are reported. Bivariate tests were used to determine statistical significance levels.

${ }^{2}$ Coefficients are based on a multiple regression that used a two-level model with random intercepts for papers. All variables were standardized. VIFs were all below 10 and the maximum condition index was below 30 . 
Table 5.

Moderator Means and Multiple Regression Results for the Ease-of-Retrieval Effect for distal.

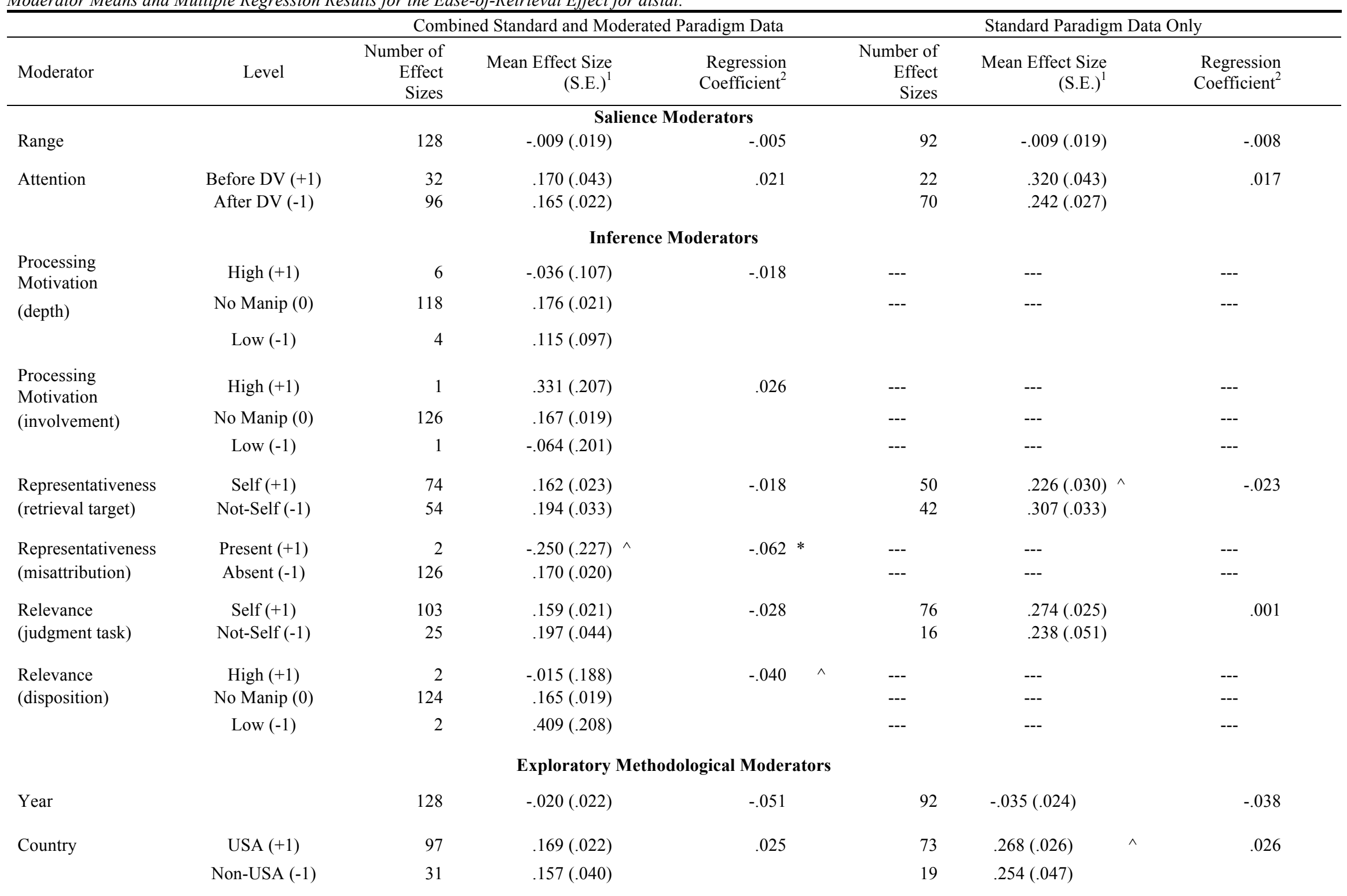


Publication Status ${ }^{3}$

Number of

measures $(\mathrm{M})$

Number of

measures (Y)

Type of dependent

measure

(attitude)
Filedrawer (+1)

Published (-1)

\section{7}

101

128

128

Attitude (+1)

Non-Attitude (-1) $.096(.045)^{\wedge}$

$.176(.019)$

$.009(.021)$

$-.019(.021)$

$.179(.028)$

$.155(.027)$
$-.038$

.002

$-.020$

$-.004$
$.212(.054)$

$.276(.025)$

$033(.020)$

$.021(.021)$

$51 \quad .275(.029)$

$41 \quad .250(.031)$
$-.049 \wedge$

.033

.019

0

Note: ${ }^{\wedge} p<.10 * p<.05 * * p<.01 * * * p<.001$.

${ }^{1}$ Sample means and standard errors were computed separately for each level, except for continuous variables for which bivariate regression slopes and associated standard errors are reported. Bivariate tests were used to determine statistical significance levels.

${ }^{2}$ Coefficients are based on a multiple regression that used a two-level model with random intercepts for papers. All variables were standardized. VIFs were all below 10 and the maximum condition index was below 30.

${ }^{3}$ Model for bivariate analyses in combined dataset was unable to be run for this covariate; we removed the random intercept for this bivariate analysis. 
Table 6.

Moderator Means and Multiple Regression Results for the Indirect Effect ( $a \times$ b) and the Direct Effect (c') Decomposition of the Ease-of-Retrieval Effect (combined dataset) for proximal.

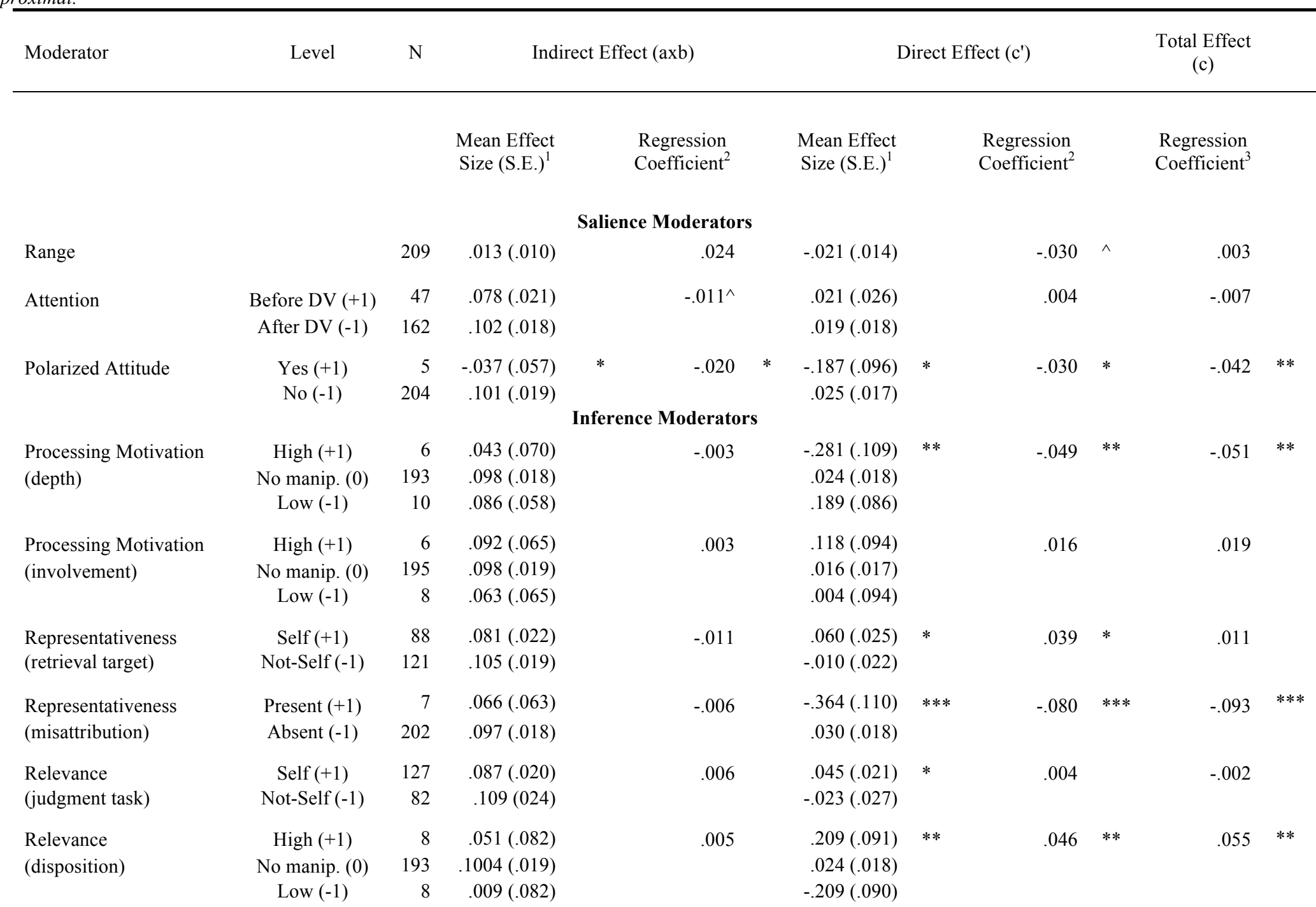

Exploratory Methodological Moderators 


\begin{tabular}{|c|c|c|c|c|c|c|c|}
\hline Year & & 209 & $.009(.009)$ & -.004 & $-.015(.014)$ & .006 & -.008 \\
\hline \multirow[t]{2}{*}{ Country } & USA $(+1)$ & 114 & $.098(.023)$ & \multirow[t]{2}{*}{-.004} & $.018(.023)$ & \multirow[t]{2}{*}{-.0001} & \multirow[t]{2}{*}{-.006} \\
\hline & Non-USA (-1) & 95 & $.095(.025)$ & & $.023(.026)$ & & \\
\hline \multirow[t]{2}{*}{ Publication Status } & Filedrawer $(+1)$ & 65 & $.072(.035)$ & \multirow[t]{2}{*}{-.005} & $-.022(.028)$ & \multirow[t]{2}{*}{$-.036^{\wedge}$} & \multirow[t]{2}{*}{-.041} \\
\hline & Published (-1) & 144 & $.102(.019)$ & & $.035(.019)$ & & \\
\hline Number of measures (M) & & 209 & $.014(.017)$ & .015 & $-.011(.017)$ & -.019 & -.001 \\
\hline Number of measures (Y) & & 209 & $-.014(.014)$ & -.017 & $.012(.017)$ & .024 & .007 \\
\hline \multirow{2}{*}{$\begin{array}{l}\text { Type of dependent } \\
\text { measure } \\
\text { (attitude) }\end{array}$} & Attitude $(+1)$ & 176 & $.087(.019)$ & \multirow[t]{2}{*}{-.012} & $.016(.019)$ & \multirow[t]{2}{*}{-.008} & \multirow[t]{2}{*}{-.026} \\
\hline & Non-Attitude (- & 33 & $.126(.032)$ & & $.033(.039)$ & & \\
\hline
\end{tabular}

Note: ${ }^{\wedge} p<.10 * p<.05 * * p<.01 * * * p<.001$

${ }^{1}$ Sample means and standard errors were computed separately for each level, except for continuous variables for which bivariate regression slopes and associated standard errors are reported. Bivariate tests were used to determine statistical significance levels.

${ }^{2}$ Coefficients are based on a multiple regression that used a two-level model with random intercepts for papers. All variables were standardized. VIFs were all below 10 and the maximum condition index was below 30 .

${ }^{3}$ The Total Effect from is provided as a benchmark. 
Table 7.

Moderator Means and Multiple Regression Results for the Indirect Effect $(a \times b)$ and the Direct Effect (c') Decomposition of the Ease-of-Retrieval Effect for distal.

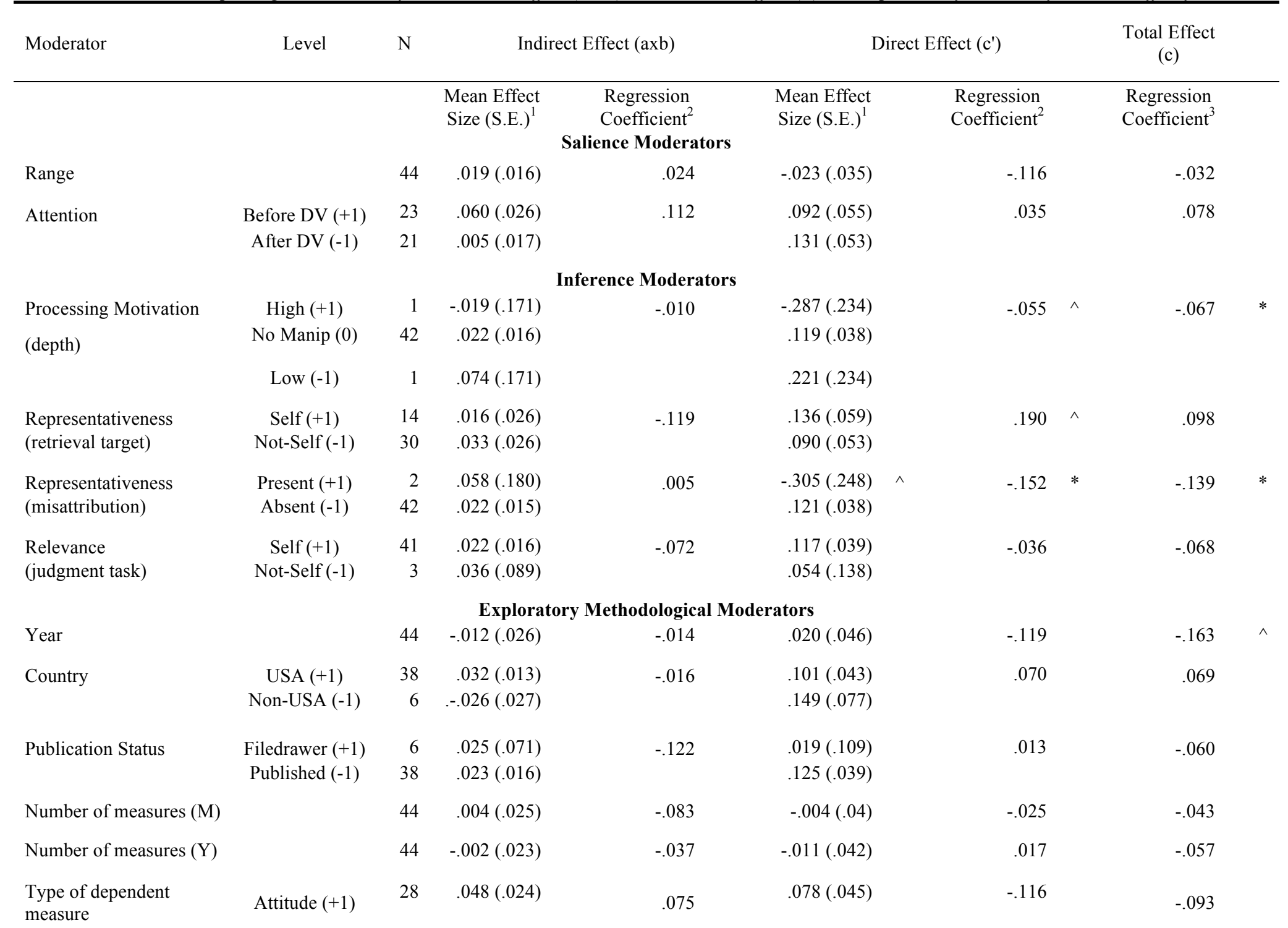


(attitude)

Note: ${ }^{\wedge} p<.10 * p<.05 * * p<.01 * * * p<.001$

${ }^{1}$ Sample means and standard errors were computed separately for each level, except for continuous variables for which bivariate regression slopes and associated standard errors are reported. Bivariate tests were used to determine statistical significance levels.

${ }^{2}$ Coefficients are based on a multiple regression that used a two-level model with random intercepts for papers. All variables were standardized. VIFs were all below 10 and the maximum condition index was below 30 .

The Total Effect is provided as a benchmark 
Table 8.

Indirect and Direct Mediation Effects for the Standard Paradigm, Adjusted for Measurement Error in M and Correlated Error between $M$ and $Y\left(r_{M M}=.8\right.$ and $e=f=.34$; see Appendix $D$ for adjustment method details).

\begin{tabular}{|c|c|c|c|c|c|}
\hline Adjustment for Potential Bias & $\begin{array}{c}\text { Indirect } \\
\text { (median) }\end{array}$ & $\begin{array}{c}\text { Direct } \\
(\text { median })\end{array}$ & $\begin{array}{c}\text { Indirect }>\text { Direct } \\
(\text { percent })\end{array}$ & $\begin{array}{c}\text { Indirect }>0 \\
\text { (percent) }\end{array}$ & $\begin{array}{r}\text { Direct }>0 \\
\text { (percent) }\end{array}$ \\
\hline \multicolumn{6}{|c|}{ Proximal effect sizes $(N=143)$} \\
\hline None & .08 & .12 & $47 \%$ & $80 \%$ & $71 \%$ \\
\hline Measurement Error in $\mathrm{M}$ & .11 & .07 & $61 \%$ & $80 \%$ & $64 \%$ \\
\hline Correlated Error between $\mathrm{M}$ and $\mathrm{Y}$ & .03 & .18 & $32 \%$ & $67 \%$ & $78 \%$ \\
\hline Both & .05 & .15 & $37 \%$ & $67 \%$ & $73 \%$ \\
\hline \multicolumn{6}{|c|}{ Distal effect sizes $(N=31)$} \\
\hline None & .03 & .25 & $13 \%$ & $74 \%$ & $90 \%$ \\
\hline Measurement Error in $\mathrm{M}$ & .04 & .29 & $13 \%$ & $68 \%$ & $97 \%$ \\
\hline Correlated Error between $\mathrm{M}$ and $\mathrm{Y}$ & -.02 & .31 & $7 \%$ & $42 \%$ & $97 \%$ \\
\hline Both & -.03 & .34 & $7 \%$ & $42 \%$ & $97 \%$ \\
\hline
\end{tabular}




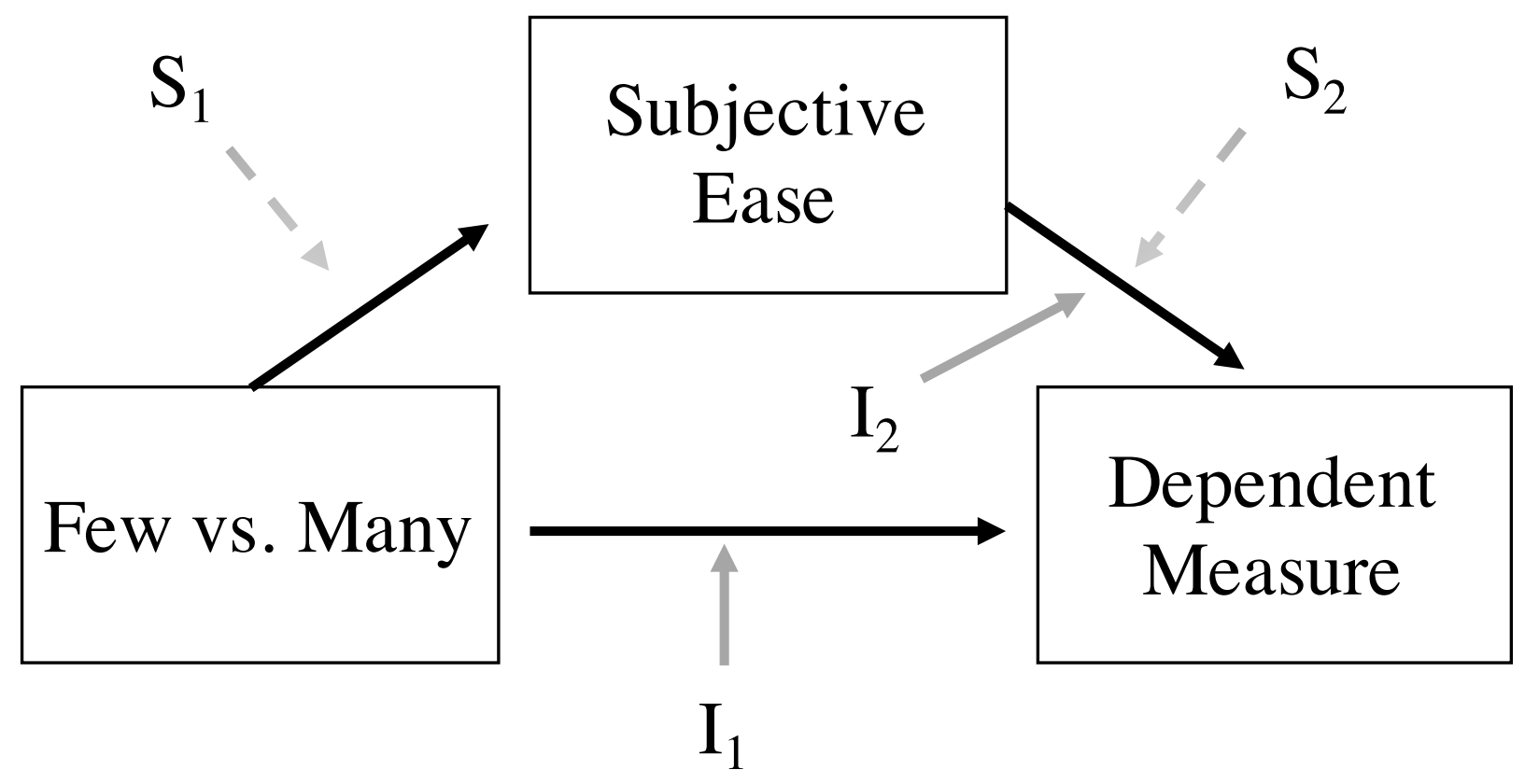

$-\infty-1$

Salience Moderators (S)

Range

Attention

Polarized Attitude
Inference Moderators (I)

Processing Motivation

Representativeness

Relevance

Polarized Attitude

Figure 1. Theoretical organization of moderators of ease-of-retrieval effect. 


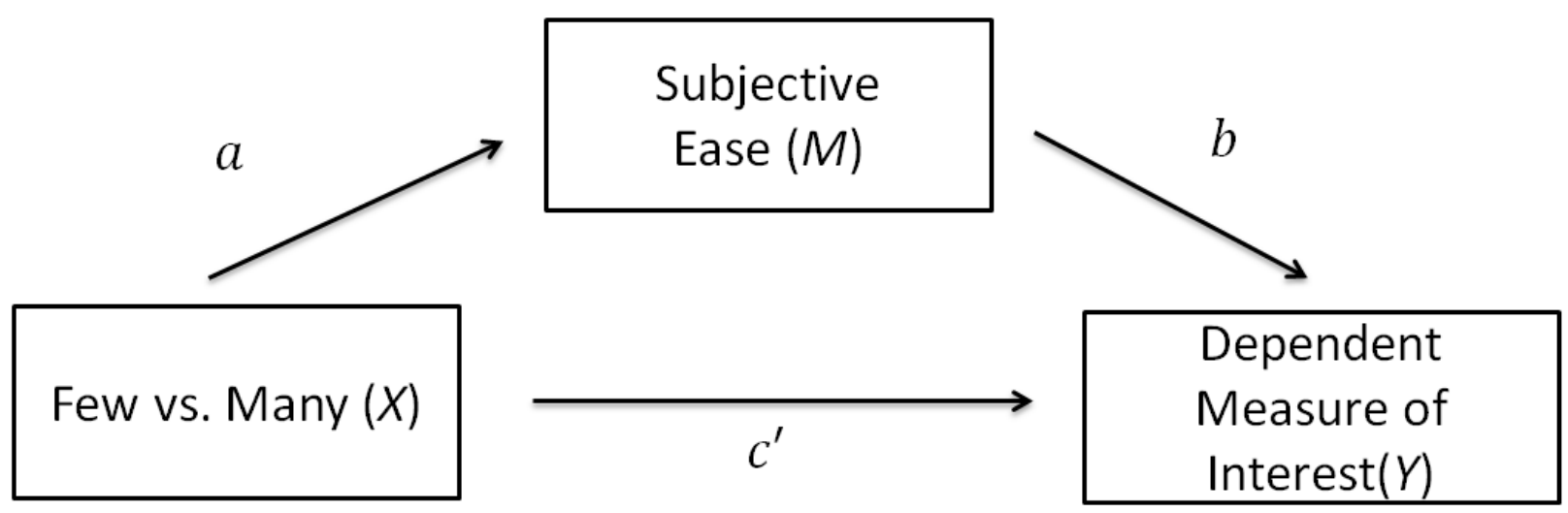

Figure 2. The mediation model of the ease-of-retrieval effect. 
A. Standard Paradigm, Proximal

30

25

20

๑゚ 15

10

5

0

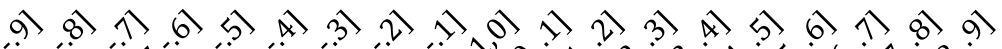

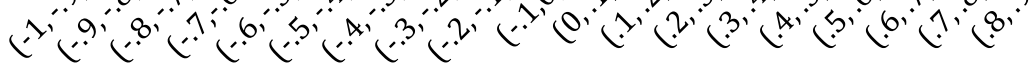

B. Moderated Paradigm, Proximal

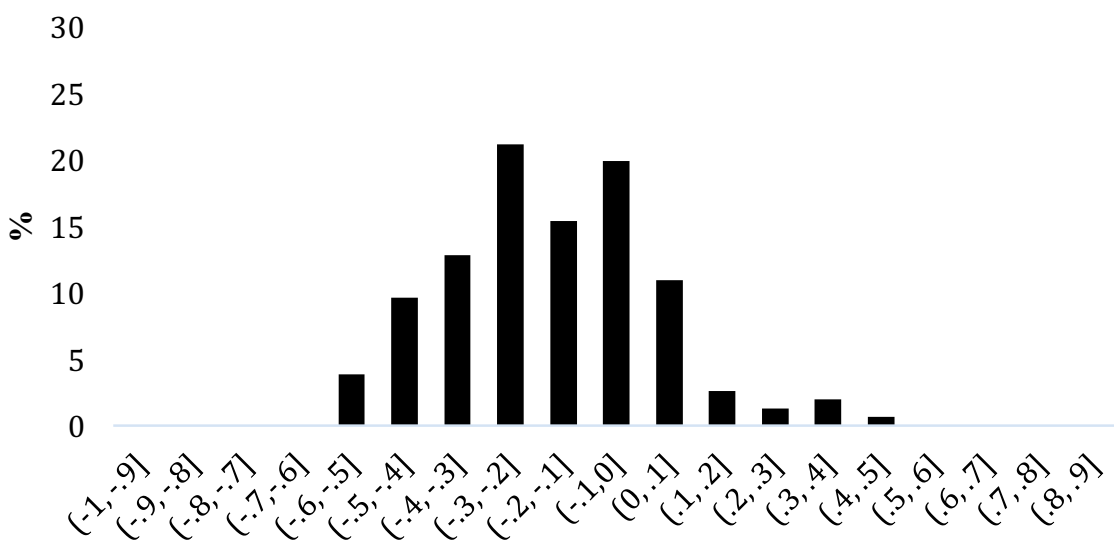

Figure 3. Distribution of proximal effect sizes in the standard (A) and moderated paradigms (B). 


\section{A. Standard Paradigm, Distal}

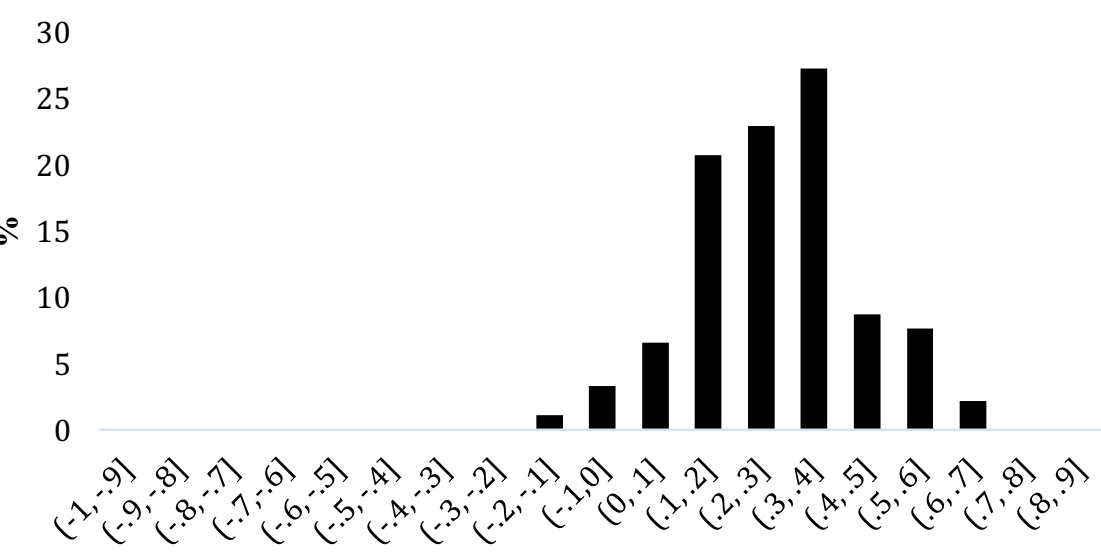

B. Moderated Paradigm, Distal

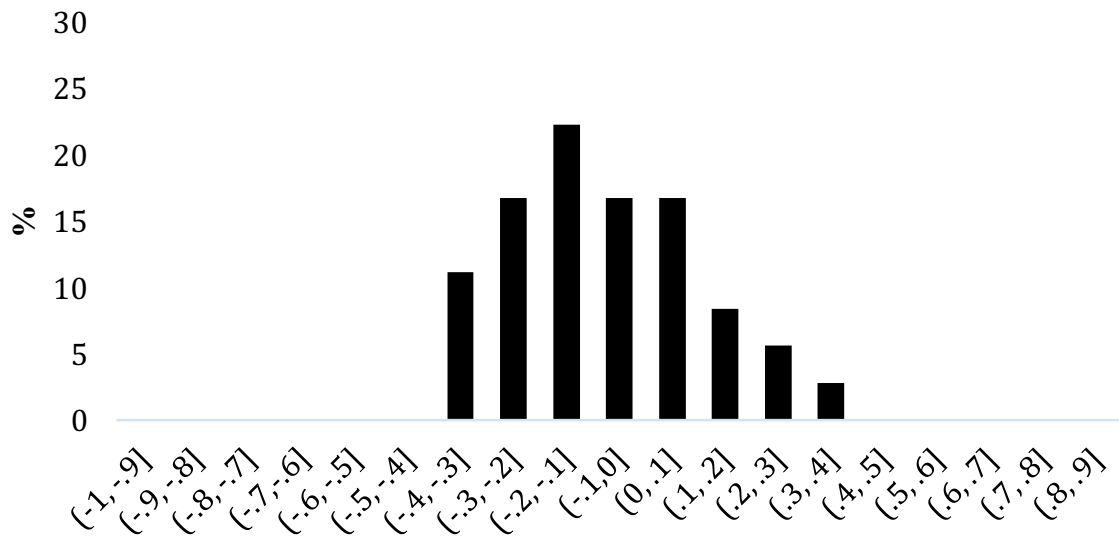

Figure 4. Distribution of distal effect sizes in the standard (A) and moderated paradigms (B). 
A. Before Trim-and-Fill (Standard left, Moderated middle, Combined right)
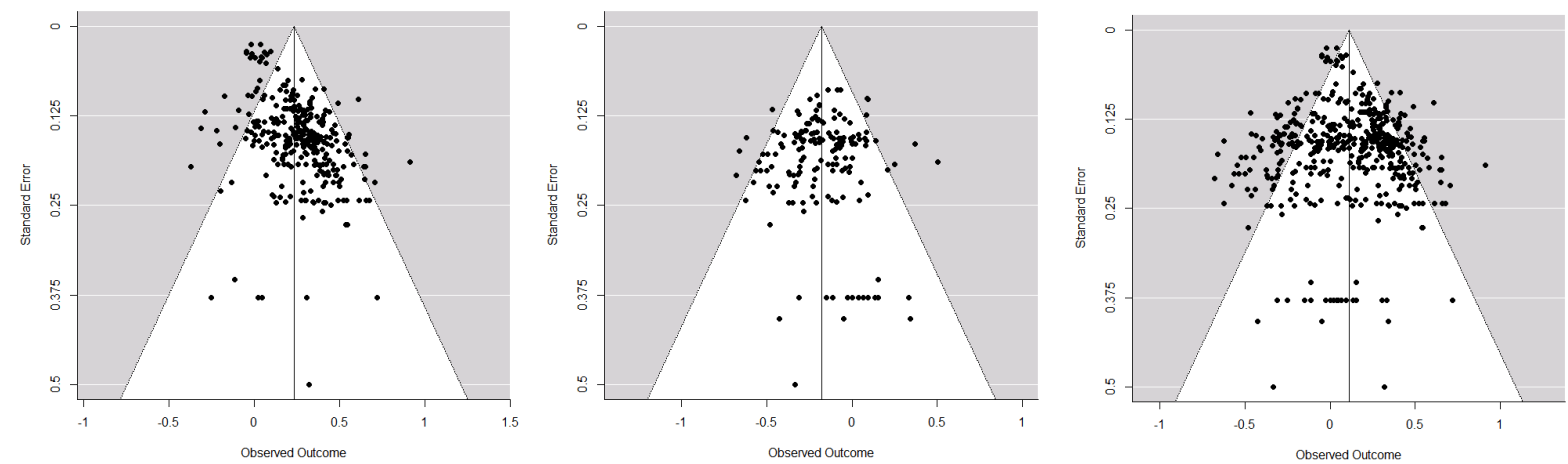

B. After Trim-and-Fill (Standard left, Moderated middle, Combined right)
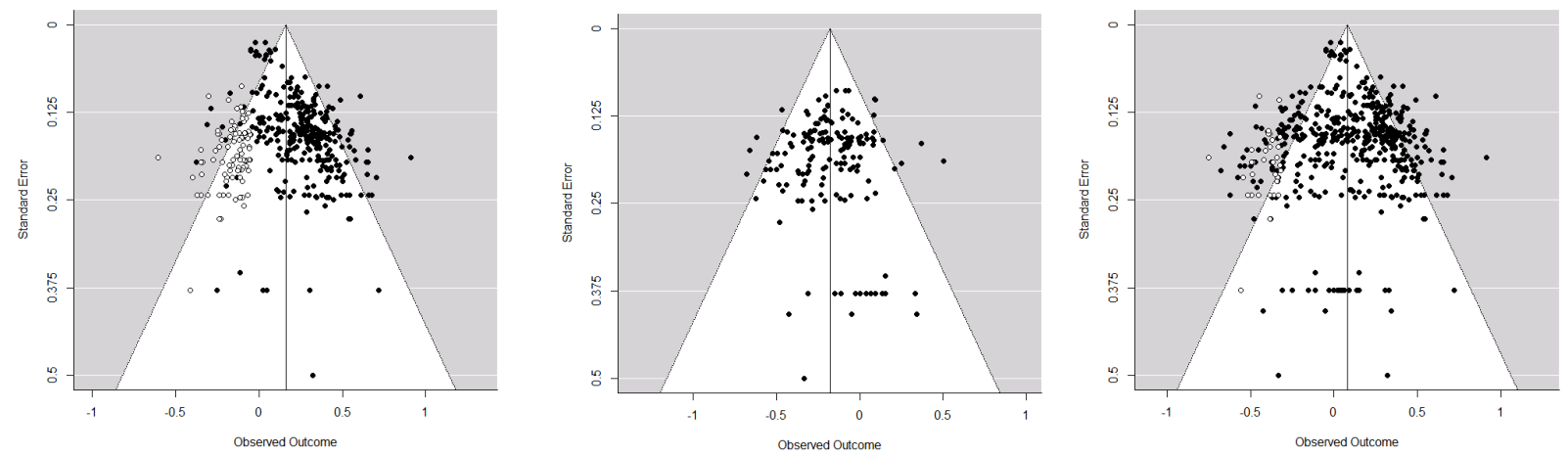

C. With Contours (Standard left, Moderated middle, Combined right)
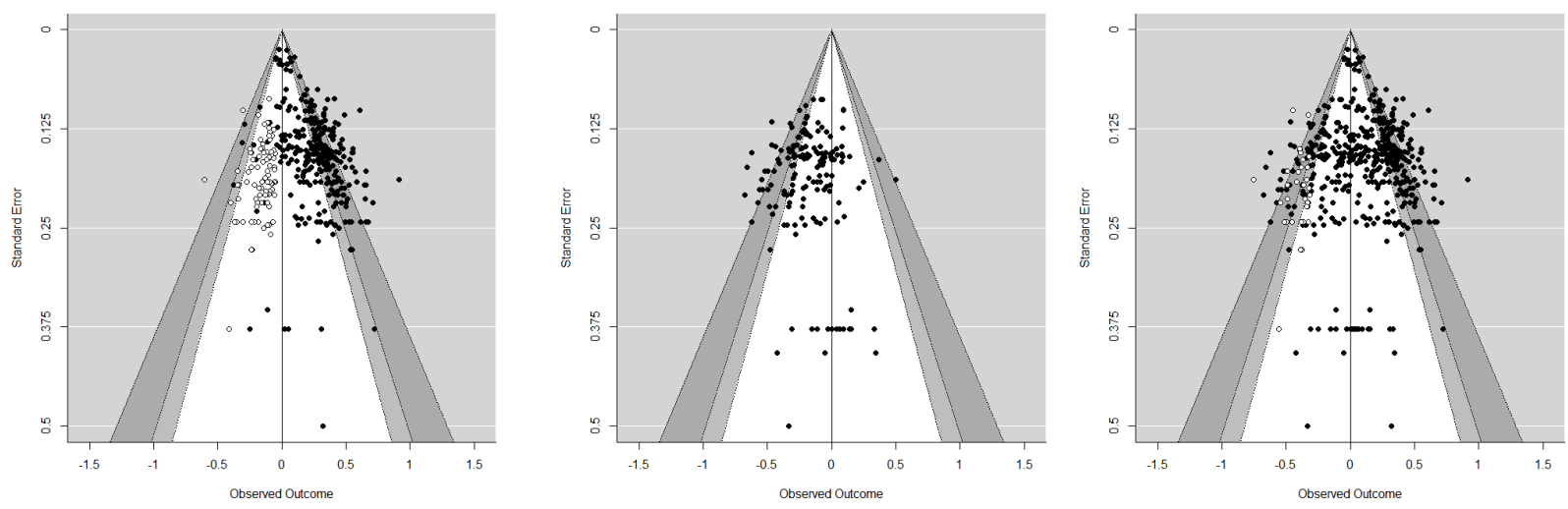

Figure 5. Funnel plots for the standard (left), moderated (middle), and combined (right) for proximal effect sizes (Fisher's $z$ ). Panel A: the funnel depicts the confidence interval for the sample mean before applying the trim-and-fill algorithm. Panel B: the funnel depicts the confidence interval after applying the trim-and-fill algorithm. Panel C: the funnel depicts alpha contours (white indicates nonsignificant, light grey .05 $<p<.10$, dark grey $p<.05$, outside of funnel $p<.01$ ) assuming the null hypothesis (i.e., $z=0$ ) is true. 
A. Before Trim-and-Fill (Standard left, Moderated middle, Combined right)
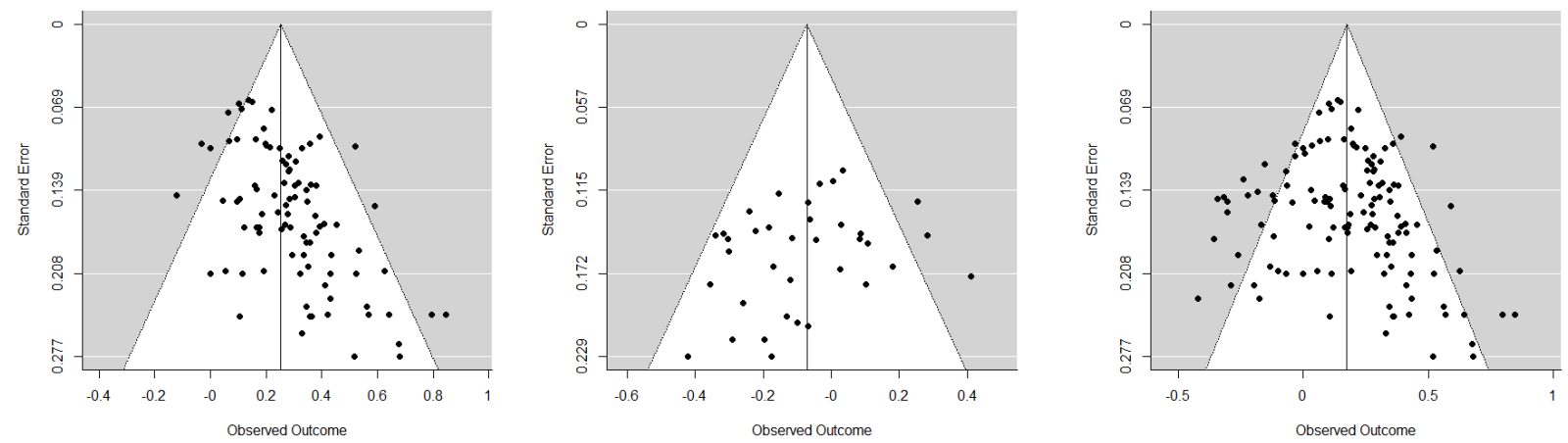

B. After Trim-and-Fill (Standard left, Moderated middle, Combined right)
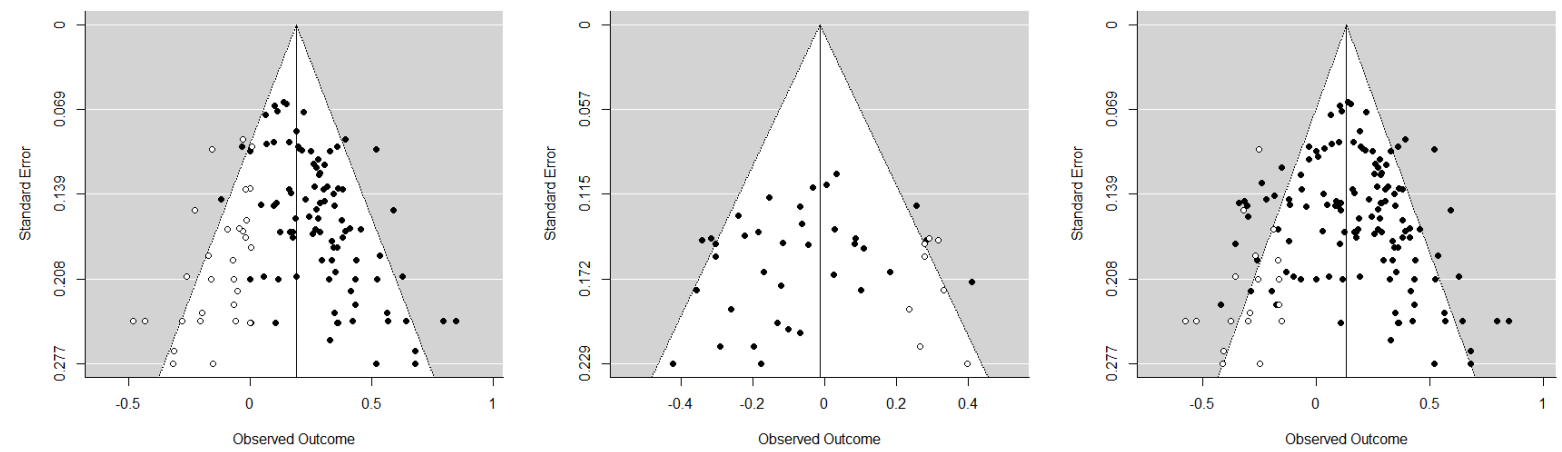

C. With Contours (Standard left, Moderated middle, Combined right)
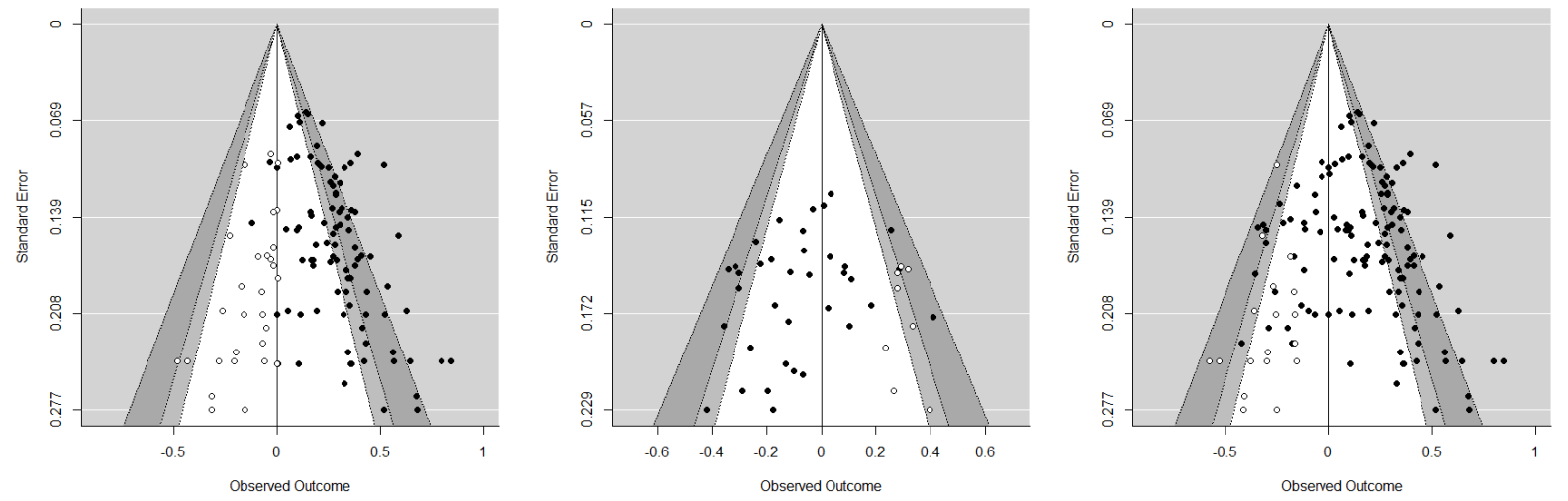

Figure 6. Funnel plots for the standard paradigm (left), moderated (middle), and combined (right) for distal effect sizes (Fisher's $z$ ). Panel A: the funnel depicts the confidence interval for the sample mean before applying the trim-and-fill algorithm. Panel B: the funnel depicts the confidence interval after applying the trim-and-fill algorithm. Panel C: the funnel depicts alpha contours (white indicates nonsignificant, light grey .05 $<p<.10$, dark grey $p<.05$, outside of funnel $p<.01$ ) assuming the null hypothesis (i.e., $z=0$ ) is true. 


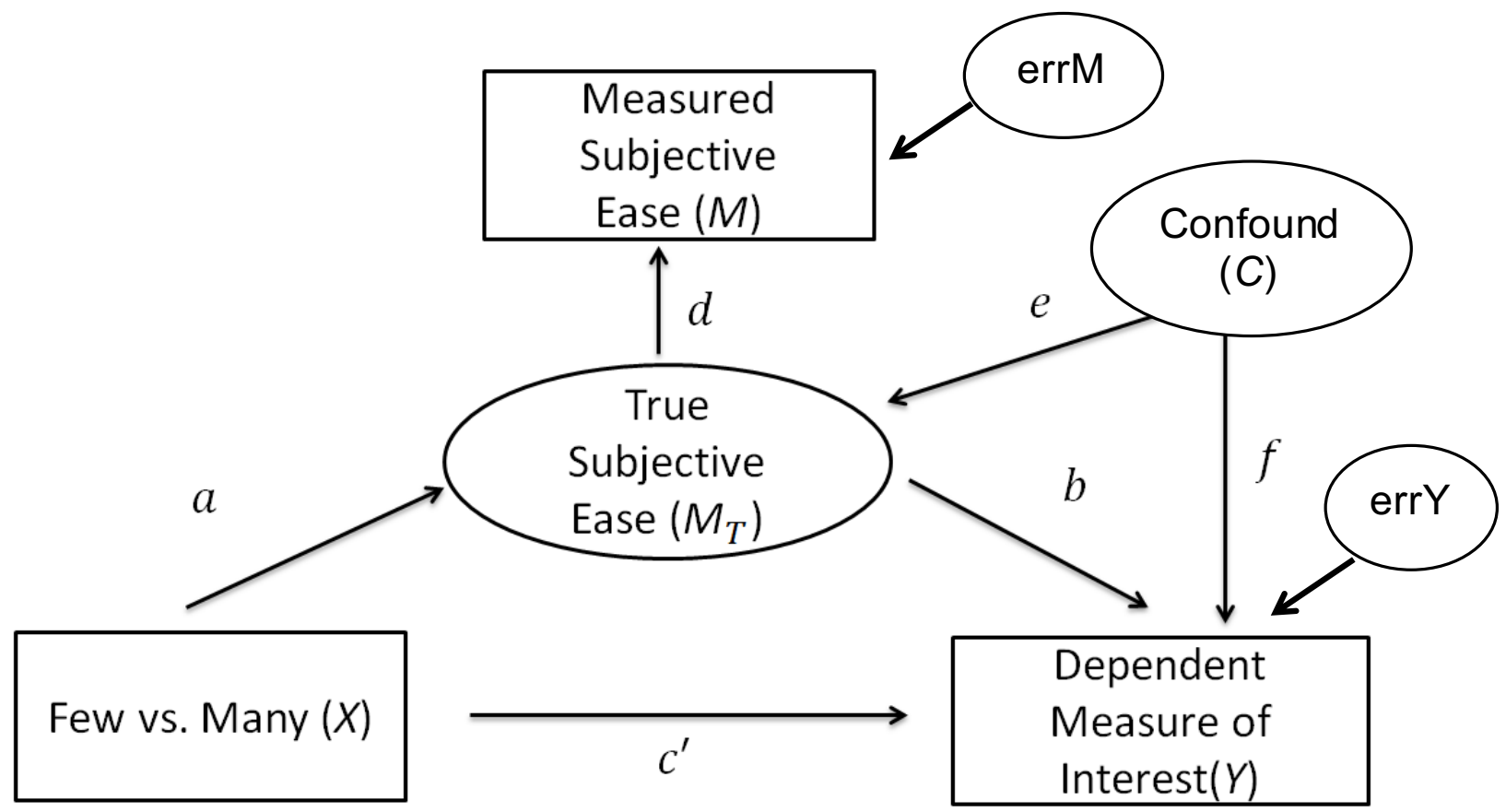

Figure 7. Mediation model that includes measurement error (errM) and correlated error due to an unmeasured confounding variable $(C)$. 


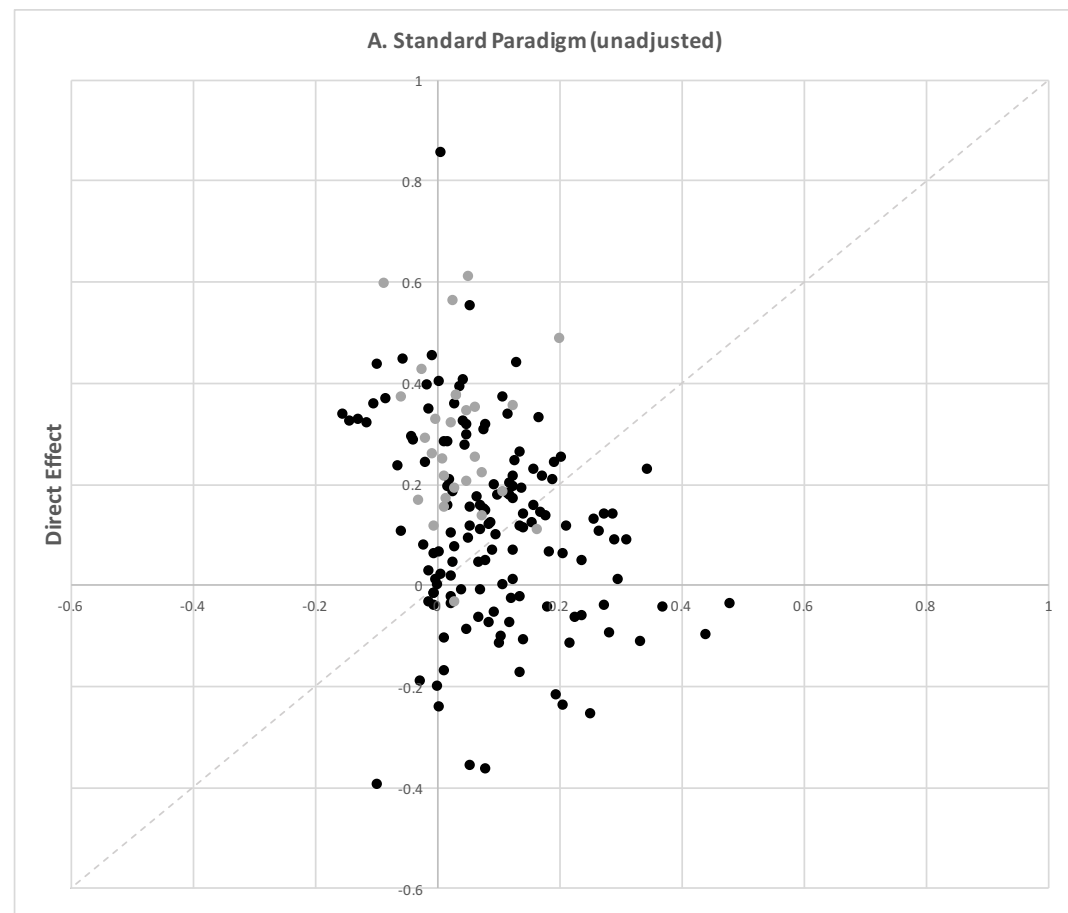

Indirect Effect (Mediation by Subjective Ease)

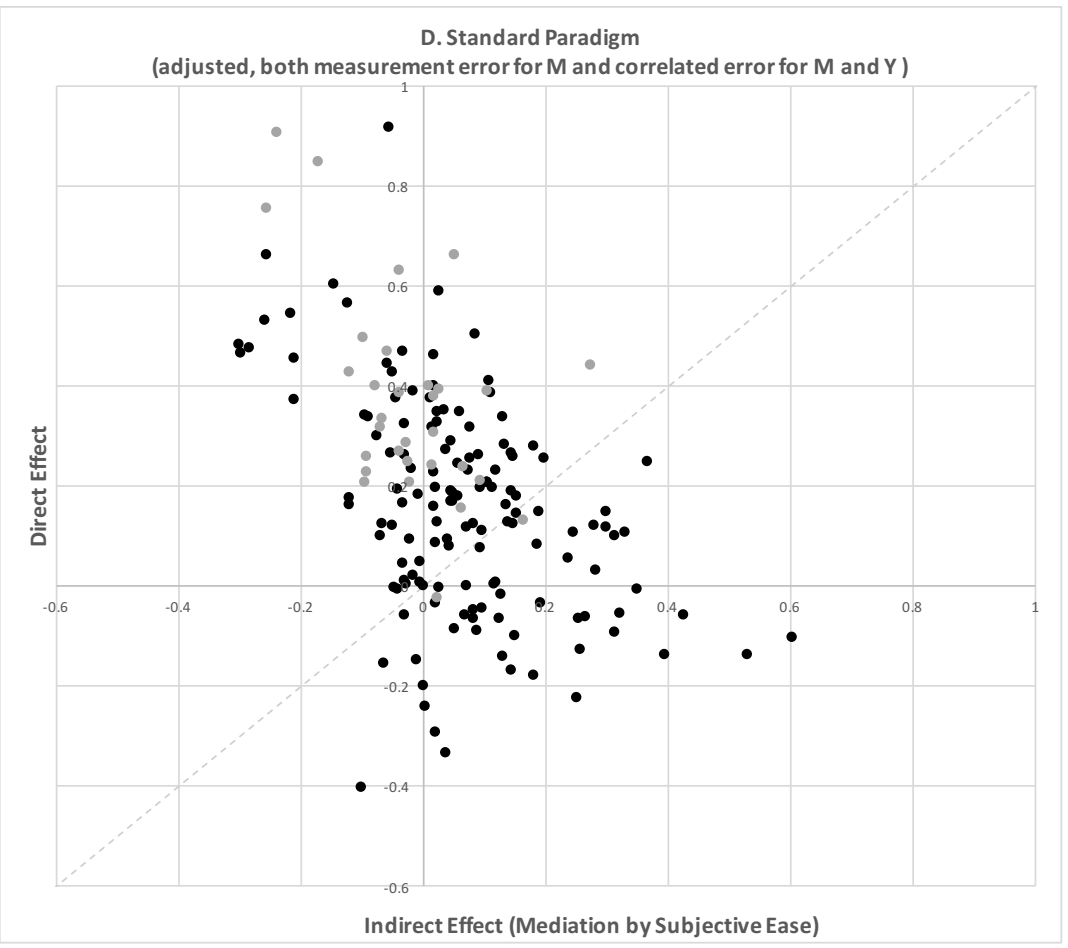

Figure 8. Scatterplots of unadjusted (Panel A) and adjusted (Panel B) indirect and direct effects for all standard paradigm observations in the triplets dataset (solid markers for proximal effect sizes, gray markers for distal effect sizes). (Note: Four outlier observations are not plotted, 2 proximal and 2 distal; however, these observations are included in the analyses reported in Table 8.) 


\section{Appendix A \\ Example e-mail for reaching out to authors}

Dear []:

[Co-author] and I are conducting a meta-analysis of the ease-of-retrieval effect. You have been a contributor to this literature, so we hope you can help us. Attached is a spreadsheet with the data we have been able to abstract from your publications.

The data we seek are correlations (as reported or computed from other reported measures) between the few-many manipulation $(\mathrm{X})$, the manipulation check on subjective difficulty $(\mathrm{M})$, and the dependent measure of interest (Y). For your attached study, this would be []. In addition to examining the basic effect, we are examining the mediation of the effect by subjective difficulty, which is why we need three correlations for each observation.

Importantly, we are separating reported results into experimental conditions that the authors present as conceptual replications of the original effect reported by Schwarz et al. (1991) -- the standard paradigm -- and conditions in which the authors change the standard paradigm in ways that they expect will moderate the effect, causing attenuation or reversal. Thus, we often get two or more observations from a single experiment.

Currently, we have data from 142 articles and dissertations, 258 experiments, and 539 observations. It is no surprise that the basic effect in the standard paradigm conditions is very robust, and this effect is reliably reduced or reversed in the non-standard conditions. However, there is a significant level of heterogeneity in the effect sizes, and we hope to identify the factors that do and do not contribute to this variation. Also, we hope to explore the role of subjective difficulty as a mediator of the effect. Regarding the latter, we have r(XY) for $85 \%$ of the observations and $\mathrm{r}(\mathrm{XM})$ for $94 \%$ of the observations, but for $\mathrm{r}(\mathrm{MY})$ only $21 \%$ of observations.

What do we need from you? First, please review how we have separated the conditions of your experiments into standard and non-standard paradigms and confirm that they are consistent with your interpretation of your manipulations. Second, we need the missing correlations. We are happy to do whatever we can to make this easier for you. Below are some options.

OPTION 1: Send us the original data. We will only use it for the purpose of computing the correlations we need.

OPTION 2: Hire a student research assistant to do this work under your direction. We reimburse you for this expense (up to some reasonable amount). Also, we would be happy to work with this student via phone/Skype.

OPTION 3: Do it yourself. Just fill in the yellow cells in the attached spreadsheet. Alternatively, we have designed a website that assists in this process. It is preloaded with the data we already have, and it has effect size "calculators" to make the task easier. Of course, the RA in Option 2 might also want to use the website.

OPTION 4: Some combination of the above, or some other process that occurs to you.

Of course, if you have unpublished experiments in your "file drawer" (new or old), we would love to have the correlations from those experiments.

Please let us know if you can help. Thanks in advance.

Regards

[Authors]

Note: While we used the phrase "very robust" to describe the effect when reaching out to authors, we caution against using this language as a template for future meta-analyses so as not to bias authors. It is possible that this language could encourage more individuals to send data, but it is also possible it may affect whether individuals with successful or unsuccessful filedrawer studies are willing to respond. 


\begin{tabular}{|c|c|c|c|c|c|c|c|c|c|c|c|c|}
\hline \multirow[t]{2}{*}{$\begin{array}{l}\text { Pap } \\
\text { er ID } \\
\end{array}$} & \multirow[t]{2}{*}{ Authors } & \multirow[t]{2}{*}{ Paper title } & \multirow[t]{2}{*}{$\begin{array}{c}\begin{array}{c}\text { Journal } \\
\text { references }\end{array} \\
\end{array}$} & \multirow[t]{2}{*}{\begin{tabular}{|c|}
$\begin{array}{c}\text { Paradig } \\
\mathbf{m}\end{array}$ \\
\end{tabular}} & \multirow[t]{2}{*}{\begin{tabular}{|c|} 
Manipurat \\
ion \\
chook
\end{tabular}} & \multirow[t]{2}{*}{\begin{tabular}{|c|}
$\begin{array}{c}\text { Moderat } \\
\text { or }\end{array}$ \\
\end{tabular}} & \multirow{2}{*}{\begin{tabular}{|c|}
$\begin{array}{c}\text { Espe- } \\
\text { riment }\end{array}$ \\
\\
\end{tabular}} & \multirow{2}{*}{\multicolumn{3}{|c|}{\begin{tabular}{|c|c|}
$r(X Y)$ & $(X M)(M Y)$ \\
Yellow \\
indicates \\
missing data
\end{tabular}}} & \multirow{3}{*}{\begin{tabular}{|l|}
\multicolumn{1}{|c|}{ Easy } \\
\\
$\begin{array}{l}\text { 2 positive } \\
\text { thoughts about } \\
\text { comprehensive } \\
\text { exams }\end{array}$ \\
\end{tabular}} & \multirow{3}{*}{\begin{tabular}{|l}
\multicolumn{1}{|c}{ Hard } \\
\\
10 positive \\
thoughts about \\
comprehensive \\
exams
\end{tabular}} \\
\hline & & & & & & & & & & & & \\
\hline 35 & $\begin{array}{l}\text { Zakary Tormala, } \\
\text { Carlos Falces, Pablo } \\
\text { Brinol, Richard Petty }\end{array}$ & $\begin{array}{l}\text { Ease of } \\
\text { retrieval } \\
\text { effects... }\end{array}$ & $\begin{array}{l}\text { Journal of } \\
\text { Personality and } \\
\text { Social Psychology } \\
2007 \\
\end{array}$ & Standard & None & & 1 & .435 & \begin{tabular}{|c|} 
No \\
Man. \\
Che \\
ck
\end{tabular} & \begin{tabular}{|c|} 
No \\
Man. \\
Che \\
ck
\end{tabular} & & \\
\hline 35 & $\begin{array}{l}\text { Zakary Tormala, } \\
\text { Carlos Falces, Pablo } \\
\text { Brinol, Richard Petty }\end{array}$ & $\begin{array}{l}\text { Ease of } \\
\text { retrieval } \\
\text { effects... }\end{array}$ & $\begin{array}{l}\text { Journal of } \\
\text { Personality and } \\
\text { Social Psychology } \\
2007 \\
\end{array}$ & Standard & None & & 2 & .336 & $\begin{array}{c}\text { No } \\
\text { Man. } \\
\text { Che } \\
\text { ok }\end{array}$ & $\begin{array}{c}\text { No } \\
\text { Man. } \\
\text { Che } \\
\text { ck }\end{array}$ & $\begin{array}{l}2 \text { negative } \\
\text { thoughts about } \\
\text { comprehensive } \\
\text { exams }\end{array}$ & $\begin{array}{l}10 \text { negative } \\
\text { thoughts about } \\
\text { comprehensive } \\
\text { exams }\end{array}$ \\
\hline 35 & $\begin{array}{l}\text { Zakary Tormala, } \\
\text { Carlos Falces, Pablo } \\
\text { Brinol, Richard Petty }\end{array}$ & $\begin{array}{l}\text { Ease of } \\
\text { retrieval } \\
\text { effects... }\end{array}$ & \begin{tabular}{|l|} 
Journal of \\
Personality and \\
Social Psychology \\
2007 \\
\end{tabular} & Standard & After & $\begin{array}{l}\text { High } \\
\text { elaboratio } \\
n\end{array}$ & 3 & .226 & .311 & .300 & $\begin{array}{l}2 \text { examples of } \\
\text { behaving } \\
\text { assertively }\end{array}$ & $\begin{array}{l}10 \text { examples of } \\
\text { behaving } \\
\text { assertively }\end{array}$ \\
\hline 35 & $\begin{array}{l}\text { Zakary Tormala, } \\
\text { Carlos Falces, Pablo } \\
\text { Brinol, Richard Petty }\end{array}$ & $\begin{array}{l}\text { Ease of } \\
\text { retrieval } \\
\text { effects... }\end{array}$ & $\begin{array}{l}\text { Journal of } \\
\text { Personality and } \\
\text { Social Psychology } \\
2007\end{array}$ & Standard & None & $\begin{array}{l}\text { High } \\
\text { elaboration }\end{array}$ & 4 & .335 & $\begin{array}{c}\text { No } \\
\text { Man. } \\
\text { Che } \\
\text { ok }\end{array}$ & $\begin{array}{c}\text { No } \\
\text { Man. } \\
\text { Che } \\
\text { ck }\end{array}$ & $\begin{array}{l}2 \text { positive } \\
\text { thoughts about } \\
\text { comprehensive } \\
\text { exams }\end{array}$ & $\begin{array}{l}10 \text { positive } \\
\text { thoughts about } \\
\text { comprehensive } \\
\text { exams }\end{array}$ \\
\hline 36 & $\begin{array}{l}\text { Zakary Tormala, } \\
\text { Richard Petty. Pablo } \\
\text { Brinol }\end{array}$ & $\begin{array}{l}\text { Ease of } \\
\text { Retrieval } \\
\text { Effects... }\end{array}$ & $\begin{array}{l}\text { Pers Soc Psychol } \\
\text { Bull } 2002\end{array}$ & $\begin{array}{c}\text { Non- } \\
\text { Standard }\end{array}$ & None & $\begin{array}{l}\text { Low Need } \\
\text { for } \\
\text { Cognition }\end{array}$ & 1 & -.257 & $\begin{array}{c}\text { No } \\
\text { Man. } \\
\text { Che } \\
\text { ok }\end{array}$ & $\begin{array}{c}\text { No } \\
\text { Man. } \\
\text { Che } \\
\text { ck }\end{array}$ & 2 thoughts against & 8 thoughts in favor \\
\hline 36 & $\begin{array}{l}\text { Zakary Tormala, } \\
\text { Richard Petty. Pablo } \\
\text { Brinol }\end{array}$ & $\begin{array}{l}\text { Ease of } \\
\text { Retrieval } \\
\text { Effects... }\end{array}$ & $\begin{array}{l}\text { Pers Soc Psychol } \\
\text { Bull } 2002\end{array}$ & Standard & None & $\begin{array}{l}\text { High Need } \\
\text { for } \\
\text { Cognition }\end{array}$ & 1 & .247 & \begin{tabular}{|c|} 
No \\
Man. \\
Che \\
ck \\
\end{tabular} & $\begin{array}{c}\text { No } \\
\text { Man. } \\
\text { Che } \\
\text { ok }\end{array}$ & 2 thoughts against & 8 thoughts in favor \\
\hline 36 & $\begin{array}{l}\text { Zakary Tormala, } \\
\text { Richard Petty. Pablo } \\
\text { Brinol }\end{array}$ & $\begin{array}{l}\text { Ease of } \\
\text { Retrieval } \\
\text { Effects... }\end{array}$ & $\begin{array}{l}\text { Pers Soc Psychol } \\
\text { Bull } 2002\end{array}$ & $\begin{array}{c}\text { Non- } \\
\text { Standard }\end{array}$ & None & $\begin{array}{l}\text { Low Need } \\
\text { for } \\
\text { Cognition }\end{array}$ & 2 & -.198 & $\begin{array}{c}\text { No } \\
\text { Man. } \\
\text { Che } \\
\text { ck }\end{array}$ & $\begin{array}{c}\text { No } \\
\text { Man. } \\
\text { Che } \\
\text { ck }\end{array}$ & 2 thoughts in favor & 8 thoughts in favor \\
\hline 36 & $\begin{array}{l}\text { Zakary Tormala, } \\
\text { Richard Petty. Pablo } \\
\text { Brinol }\end{array}$ & $\begin{array}{l}\text { Ease of } \\
\text { Retrieval } \\
\text { Effects... }\end{array}$ & $\begin{array}{l}\text { Pers Soc Psychol } \\
\text { Bull } 2002\end{array}$ & Standard & None & $\begin{array}{l}\text { High Need } \\
\text { for } \\
\text { Cognition }\end{array}$ & 2 & .246 & $\begin{array}{c}\text { No } \\
\text { Man. } \\
\text { Che } \\
\text { ck }\end{array}$ & $\begin{array}{c}\text { No } \\
\text { Man. } \\
\text { Che } \\
\text { ck }\end{array}$ & 2 thoughts in favor & 8 thoughts in favor \\
\hline 36 & $\begin{array}{l}\text { Zakary Tormala, } \\
\text { Richard Petty. Pablo } \\
\text { Brinol }\end{array}$ & $\begin{array}{l}\text { Ease of } \\
\text { Retrieval } \\
\text { Effects... }\end{array}$ & $\begin{array}{l}\text { Pers Soc Psychol } \\
\text { Bull } 2002\end{array}$ & Standard & After & $\begin{array}{l}\text { High } \\
\text { elaboration }\end{array}$ & 3 & & .720 & & $\begin{array}{l}2 \text { positive } \\
\text { thoughts while } \\
\text { reading about } \\
\text { comprehensive } \\
\text { exampolicy }\end{array}$ & $\begin{array}{l}10 \text { positive } \\
\text { thoughts about } \\
\text { comprehensive } \\
\text { exam policy }\end{array}$ \\
\hline 55 & $\begin{array}{l}\text { Kenneth G. DeMarree, } \\
\text { Chris Loersch, Pablo } \\
\text { Brinol, Richard Petty. } \\
\text { Keith Payne, Derek } \\
\text { Rucker }\end{array}$ & $\begin{array}{l}\text { From } \\
\text { Primed } \\
\text { Construct to } \\
\ldots\end{array}$ & $\begin{array}{l}\text { Pers Soc Psychol } \\
\text { Bull } 2012\end{array}$ & Standard & After & - & 2 & .255 & .331 & & $\begin{array}{l}4 \text { times they had } \\
\text { tried very hard to } \\
\text { achieve some } \\
\text { task }\end{array}$ & $\begin{array}{l}10 \text { times they } \\
\text { had tried very } \\
\text { hard to achieve } \\
\text { some task }\end{array}$ \\
\hline 108 & $\begin{array}{l}\text { Pablo Brinol, } \\
\text { PichardE. Petty, } \\
\text { Zakary L. Tormala }\end{array}$ & $\begin{array}{l}\text { The } \\
\text { Malleable } \\
\text { Meaning of }\end{array}$ & $\begin{array}{l}\text { Psychological } \\
\text { Science } 2006\end{array}$ & Standard & None & $\begin{array}{l}\text { Ease is } \\
\text { good }\end{array}$ & 1 & .350 & $\begin{array}{c}\text { No } \\
\text { Man. } \\
\text { Che } \\
\text { ok }\end{array}$ & $\begin{array}{c}\text { No } \\
\text { Man. } \\
\text { Che } \\
\text { ck }\end{array}$ & $\begin{array}{l}2 \text { reasons in favor } \\
\text { of comprehensive } \\
\text { exams }\end{array}$ & $\begin{array}{l}10 \text { reasons in favor } \\
\text { of comprehensive } \\
\text { exams }\end{array}$ \\
\hline 108 & $\begin{array}{l}\text { Pablo Brinol, } \\
\text { RichardE. Petty, } \\
\text { Zakary L. Tormala }\end{array}$ & $\begin{array}{l}\text { The } \\
\text { Malleable } \\
\text { Meaning of }\end{array}$ & $\begin{array}{l}\text { Psychological } \\
\text { Science } 2006\end{array}$ & Standard & None & Ease is bad & 1 & .383 & $\begin{array}{c}\text { No } \\
\text { Man. } \\
\text { Che } \\
\text { ok }\end{array}$ & $\begin{array}{c}\text { No } \\
\text { Man. } \\
\text { Che } \\
\text { ck }\end{array}$ & $\begin{array}{l}2 \text { reasons in favor } \\
\text { of comprehensive } \\
\text { exams }\end{array}$ & $\begin{array}{l}10 \text { reasons in favor } \\
\text { of comprehensive } \\
\text { exams }\end{array}$ \\
\hline
\end{tabular}

Figure A1. Example sheet sent to authors to request missing data and to verify our interpretation of their studies. 


\section{Appendix B \\ Table of Effect Sizes}

Table B1. List of proximal studies using a few-versus-many manipulation in the database-proximal effect sizes.

\begin{tabular}{|c|c|c|c|c|c|c|c|c|c|c|}
\hline Paper & Exp & Source ${ }^{1}$ & Topic Retrieved & $\begin{array}{l}\text { Difficulty } \\
\text { Question }^{2}\end{array}$ & Few & Many & DV & Misattribution $^{3}$ & XY Std & XY Mod \\
\hline $\begin{array}{l}\text { Aarts \& Dijksterhuis } \\
\qquad(1999)\end{array}$ & 1 & $\mathrm{~J}$ & Biking instances & $\mathrm{A}$ & 3 & 8 & $\begin{array}{l}\text { Frequency of } \\
\text { usage estimate }\end{array}$ & $\mathrm{N}$ & $\mathrm{r}=.23, \mathrm{~N}=78$ & - \\
\hline $\begin{array}{l}\text { Aarts \& Dijksterhuis } \\
\text { (1999) }\end{array}$ & 2 & $\mathrm{~J}$ & Biking instances & $\mathrm{B}$ & 3 & 8 & $\begin{array}{l}\text { Frequency of } \\
\text { usage stimate }\end{array}$ & $\mathrm{N}$ & $\mathrm{r}=.30, \mathrm{~N}=51$ & $\begin{aligned} \mathrm{r} & =-.09, \mathrm{~N} \\
& =49\end{aligned}$ \\
\hline Aladjem (2010) & 1 & $\mathrm{D}$ & Reasons to drive a BMW & $\mathrm{B}$ & 1 & 10 & $\begin{array}{l}\text { Attitude- } \\
\text { assertion effect } \\
\text { (enjoyment of } \\
\text { listing task); } \\
\text { attitude }\end{array}$ & $\mathrm{N}$ & $\mathrm{r}=.32, \mathrm{~N}=69.5$ & $\begin{aligned} r & =-.30, \mathrm{~N} \\
& =69.5\end{aligned}$ \\
\hline Aladjem (2010) & 2 & $\mathrm{D}$ & $\begin{array}{l}\text { Reasons why Dutch team would win } \\
\text { Soccer World }\end{array}$ & $\mathrm{B}$ & 1,2 & 7,10 & $\begin{array}{l}\text { Attitude- } \\
\text { assertion effect } \\
\text { (enjoyment of } \\
\text { listing task); } \\
\text { attitude }\end{array}$ & $\mathrm{N}$ & $\mathrm{r}=.30, \mathrm{~N}=77.5$ & $\begin{aligned} \mathrm{r} & =-.44, \mathrm{~N} \\
& =77.5\end{aligned}$ \\
\hline Aladjem (2010) & 3 & $\mathrm{D}$ & $\begin{array}{l}\text { Pro/Con reasons in favor of } \\
\text { presidential ticket }\end{array}$ & A & 1 & 10 & $\begin{array}{l}\text { Attitude- } \\
\text { assertion effect } \\
\text { (enjoyment of } \\
\text { listing task); } \\
\text { attitude }\end{array}$ & $\mathrm{N}$ & $\mathrm{r}=.32, \mathrm{~N}=65$ & $\begin{aligned} \mathrm{r}= & -.31, \mathrm{~N} \\
& =74\end{aligned}$ \\
\hline $\begin{array}{l}\text { Alter \& Balcetis } \\
\quad(2010)\end{array}$ & 3 & $\mathrm{~J}$ & $\begin{array}{l}\text { Reasons NY (C1) vibrant and } \\
\text { exciting/ (C2) dirty and dangerous }\end{array}$ & $\mathrm{N}$ & 2 & 10 & $\begin{array}{l}\text { Attitude towards } \\
\text { NYC }\end{array}$ & $\mathrm{N}$ & $\begin{array}{c}\mathrm{C} 1: \mathrm{r}=.34, \mathrm{~N}= \\
30, \mathrm{C} 2: \mathrm{r}=.25, \mathrm{~N} \\
\quad=30\end{array}$ & - \\
\hline Angle (2012) & pilot & $\mathrm{D}$ & $\begin{array}{l}\text { Behaviors engaged in that } \\
\text { demonstrate university spirit }\end{array}$ & $\mathrm{N}$ & 4 & 12 & $\begin{array}{l}\text { Choice of } \\
\text { University- } \\
\text { related lottery }\end{array}$ & $\mathrm{N}$ & $\mathrm{r}=.29, \mathrm{~N}=61$ & - \\
\hline Armitage (2007) & 1 & $\mathrm{~J}$ & $\begin{array}{c}\text { Instances of taking stairs instead of } \\
\text { elevator }\end{array}$ & A & 3 & 8 & $\begin{array}{l}\text { Frequency } \\
\text { estimate of } \\
\text { stairs; attitude } \\
\text { towards stairs, } \\
\text { behavioral } \\
\text { intention } \\
\text { towards stairs }\end{array}$ & $\mathrm{N}$ & $\mathrm{r}=.23, \mathrm{~N}=83$ & - \\
\hline Armitage (2007) & 2 & $\mathrm{~J}$ & $\begin{array}{c}\text { Instances of volunteering to help } \\
\text { others }\end{array}$ & A & 3 & 8 & $\begin{array}{l}\text { Frequency } \\
\text { estimate of } \\
\text { volunteering; }\end{array}$ & $\mathrm{N}$ & $\mathrm{r}=.27, \mathrm{~N}=77$ & - \\
\hline
\end{tabular}




\begin{tabular}{|c|c|c|c|c|c|c|c|}
\hline Ask et al. (2012) & 1 & $\mathrm{~J}$ & (C1) Truth/ (C2) lie clues & B & 2 & 6 & $\begin{array}{l}\text { Credibility } \\
\text { judgment }\end{array}$ \\
\hline $\begin{array}{l}\text { Avnet, Pham, \& } \\
\text { Stephen (2012) }\end{array}$ & 1 & $\mathrm{~J}$ & Times correct in trusting feelings & A & 2 & 10 & $\begin{array}{c}\text { \# of Feeling } \\
\text { Related Reasons } \\
\text { used to justify } \\
\text { evaluation of } \\
\text { book; trust in } \\
\text { feelings }\end{array}$ \\
\hline $\begin{array}{l}\text { Avnet, Pham, \& } \\
\text { Stephen (2012) }\end{array}$ & 3 & $\mathrm{~J}$ & Times correct in trusting feelings & A & 2 & 10 & $\begin{array}{c}\text { reliance on } \\
\text { feelings to make } \\
\text { choice }\end{array}$ \\
\hline Bares (2007) & 1 & $\mathrm{D}$ & Shy/mean/friendly/nice/books liked & A & 1,3 & 5,8 & $\begin{array}{c}\text { How much do } \\
\text { you like being } \\
\text { friendly } \\
\text { (shy/friendly); } \\
\text { How much do } \\
\text { people like you } \\
\text { (mean/nice); } \\
\text { How much do } \\
\text { you like reading } \\
\text { (book); } \\
\text { frequency }\end{array}$ \\
\hline
\end{tabular}
$\begin{array}{ll}\mathrm{r}=.30, \mathrm{~N}=10 ; \mathrm{r} & \mathrm{r}=-.15, \mathrm{~N} \\ =.02, \mathrm{~N}=10 ; \mathrm{r}= & =10 ; \mathrm{r}=-\end{array}$ $-.11, \mathrm{~N}=11 ; \mathrm{r}=\quad .05, \mathrm{~N}=9$ $.62, \mathrm{~N}=10 ; \mathrm{r}=\mathrm{r}=.15, \mathrm{~N}$ $05, \mathrm{~N}=10 ; \mathrm{r}=-\quad=11, \mathrm{r}=$ $.25, \mathrm{~N}=10 \quad 0, \mathrm{~N}=10$; $\mathrm{r}=-.30, \mathrm{~N}$ $=10 ; \mathrm{r}=$ $.06, \mathrm{~N}=$ $10 ; \mathrm{r}=$

$15, \mathrm{~N}=$ $10 ; \mathrm{r}=\mathrm{-}$ $40, \mathrm{~N}=$ $9 ; \mathrm{r}=.33$, $\mathrm{N}=9 ; \mathrm{r}=$ $.09, \mathrm{~N}=$ $10 ; \mathrm{r}=-$

$.11, \mathrm{~N}=$ $10 ; \mathrm{r}=$ $.04, \mathrm{~N}=$ $10 ; \mathrm{r}=$

$14, \mathrm{~N}=$ $10 ; \mathrm{r}=$ $.03, \mathrm{~N}=$ 10 


\begin{tabular}{|c|c|c|c|}
\hline $\begin{array}{l}\text { Bartels \& Urminsky } \\
\qquad \text { (2011) }\end{array}$ & 3 & $\mathrm{~J}$ & $\begin{array}{l}\text { Reasons identity would remain } \\
\text { stable }\end{array}$ \\
\hline Belli et al. (1998) & 1 & $\mathrm{~J}$ & $\begin{array}{l}\text { Specific events experienced when 5- } \\
7 \text { and } 8-10 \text { years old }\end{array}$ \\
\hline Belli et al. (1998) & 2 & $\mathrm{~J}$ & $\begin{array}{l}\text { Specific events experienced when 5- } \\
7 \text { and 8-10 years old }\end{array}$ \\
\hline Bianchi et al. (2009) & 3 & $\mathrm{~J}$ & $\begin{array}{c}\text { Positive aspects of the group the } \\
\text { Germans }\end{array}$ \\
\hline $\begin{array}{l}\text { Biswas, Keller, \& } \\
\text { Burman (2012) }\end{array}$ & 1 & $\mathrm{~J}$ & $\begin{array}{c}\text { Reasons car might have starting } \\
\text { problems }\end{array}$ \\
\hline $\begin{array}{l}\text { Biswas, Keller, \& } \\
\text { Burman (2012) }\end{array}$ & 2 & $\mathrm{~J}$ & $\begin{array}{l}\text { Reasons car might have starting } \\
\text { problems (C1) high need for closure, } \\
\text { (C2) low need for closure }\end{array}$ \\
\hline $\begin{array}{l}\text { Biswas, Keller, \& } \\
\text { Burman (2012) }\end{array}$ & 3 & $\mathrm{~J}$ & $\begin{array}{c}\text { Performance-related problems of } \\
\text { music CD }(\mathrm{C} 1) \text { neutral exp }(\mathrm{C} 2) \\
\text { negative exp }\end{array}$ \\
\hline $\begin{array}{l}\text { Biswas, Keller, \& } \\
\text { Burman (2012) }\end{array}$ & 4 & $\mathrm{~J}$ & $\begin{array}{c}\text { Reasons car might have starting } \\
\text { problems }(\mathrm{C} 1) \text { cue absent }(\mathrm{C} 2) \text { cue } \\
\text { present }\end{array}$ \\
\hline
\end{tabular}

friendly

(shy/friendly)

How much do

people like you

(mean/nice);

How much do

you like reading

$$
\text { (book) }
$$

Connectedness

to future self

Judgment of
childhood

memory

Judgment of

childhood

memory

Ingroup

projection

ratings; social

projection rating

Probability of 5-

year old used

Volkswagen

$$
\text { failing }
$$

A

4

12

Probability of 5year old used

Volkswagen

$$
\text { failing }
$$

Probability of

typical music

CD from same

company having

performance-

related problems

within 6 months of purchase

Probability of 5-

year old used

Volkswagen

failing; number

of possible

reasons for a car

to have starting problems
$-.01, \mathrm{~N}=39 ; \mathrm{r}=$

$.18, \mathrm{~N}=39$

$=.23, \mathrm{~N}=97$

$\mathrm{r}=.18, \mathrm{~N}=152$

$\mathrm{r}=.21, \mathrm{~N}=107$

$\mathrm{r}=.35, \mathrm{~N}=66$

$\mathrm{r}=.39, \mathrm{~N}=41$

$\mathrm{C} 1: \mathrm{r}=.43, \mathrm{~N}=$

39

$\mathrm{C} 2: \mathrm{r}=$

$.08, \mathrm{~N}=$

39

$\mathrm{C} 1: \mathrm{r}=.32 \mathrm{~N}=$

45

C2: $\mathrm{r}=-$

$.28 \mathrm{~N}=49$

C2

$$
\begin{array}{cc}
\mathrm{C} 1: \mathrm{r}=.28 \mathrm{~N}= & \mathrm{C} 2: \mathrm{r}=- \\
50 & .27 \mathrm{~N}=50
\end{array}
$$




\begin{tabular}{|c|c|c|c|c|c|c|c|}
\hline Bohner et al. (2002) & 1 & $\mathrm{~J}$ & $\begin{array}{l}\text { Reasons of personal behaviors that } \\
\text { would increase/decrease risk of } \\
\text { rape; (C1) no pres + low RMA } \\
\text { +decr (C2) time pres + low RMA + } \\
\text { decr (C3) no pres + low RMA + incr } \\
\text { (C4) time pres + low RMA + incr } \\
\text { (C5) time pres + high RMA + incr } \\
\text { (C6) no pres + high RMA + decr, } \\
\text { (C7) time pres + high RMA + decr, } \\
\text { (C8) no pres + high RMA + incr }\end{array}$ & $\mathrm{B}$ & 2 & 6 & $\begin{array}{l}\text { Vulnerability to } \\
\text { sexual assault }\end{array}$ \\
\hline $\begin{array}{l}\text { Brinol, Petty, \& } \\
\text { Tormala (2006) }\end{array}$ & 1 & $\mathrm{~J}$ & $\begin{array}{l}\text { Reasons in favor of comprehensive } \\
\text { exams; (C1) ease is good, (C2) ease } \\
\text { is bad }\end{array}$ & $\mathrm{N}$ & 2 & 10 & $\begin{array}{l}\text { Attitude } \\
\text { favorability } \\
\text { towards senior } \\
\text { comprehensive } \\
\text { exams }\end{array}$ \\
\hline Broemer (2001) & 1 & $\mathrm{~J}$ & $\begin{array}{l}\text { (C1) Desired/ (C2) undesired end } \\
\text { states in relationship }\end{array}$ & $\mathrm{B}$ & 5 & 10 & $\begin{array}{l}\text { Interpersonal } \\
\text { closeness }\end{array}$ \\
\hline Bulbul (2007) & $4 \mathrm{~b}$ & $\mathrm{D}$ & Reasons why or why not to purchase & A & 2 & 10 & $\begin{array}{c}\text { Assortment size } \\
\text { (small or large) } \\
\text { preference }\end{array}$ \\
\hline $\begin{array}{l}\text { Carter \& Dunning } \\
\text { (2008) }\end{array}$ & 1 & $\mathrm{U}$ & $\begin{array}{c}(\mathrm{C} 1, \mathrm{C} 3, \mathrm{C} 5) \text { Positive/ }(\mathrm{C} 2, \mathrm{C} 4) \\
\text { negative attributes about }(\mathrm{C} 1, \mathrm{C} 2, \\
\mathrm{C} 3) \text { George Bush/ }(\mathrm{C} 3, \mathrm{C} 5) \text { Obama; } \\
(\mathrm{C} 1, \mathrm{C} 2, \mathrm{C} 5) \text { Democrat or }(\mathrm{C} 3, \mathrm{C} 4) \\
\text { Republican }\end{array}$ & A & 2 & 8 & $\begin{array}{l}\text { Evaluation of } \\
\text { President; } \\
\text { judged success } \\
\text { of presidency }\end{array}$ \\
\hline $\begin{array}{l}\text { Carter \& Dunning } \\
\text { (2009) }\end{array}$ & 2 & $\mathrm{U}$ & $\begin{array}{l}\text { Arguments in favor of/against } \\
\text { constitutional amendment banning } \\
\text { gay marriage }(\mathrm{C} 1) \text { against }+ \text { against, } \\
\text { (C2) against }+ \text { originally for, }(\mathrm{C} 3) \\
\text { for }+ \text { originally against }\end{array}$ & $\mathrm{A}$ & 2 & 7 & $\begin{array}{l}\text { Attitude } \\
\text { Certainty }\end{array}$ \\
\hline $\begin{array}{l}\text { Carter \& Dunning } \\
\text { (2011) }\end{array}$ & 3 & $\mathrm{U}$ & $\begin{array}{c}\text { Factors that would help Obama in } \\
2012 \text { for }(\mathrm{C} 1) \text { democrat or }(\mathrm{C} 2) \\
\text { republican }\end{array}$ & A & 2 & 8 & $\begin{array}{l}\text { Subjective } \\
\text { Likelihood; } \\
\text { percentage of } \\
\text { popular vote for } \\
\text { Obama }\end{array}$ \\
\hline $\begin{array}{l}\text { Carter \& Dunning } \\
\text { (2009) }\end{array}$ & 4 & $\mathrm{U}$ & $\begin{array}{l}\text { (C1) charitable or }(\mathrm{C} 2) \text { Neutral / } \\
\text { introverted behaviors }\end{array}$ & A & 2 & 12 & $\begin{array}{l}\text { Trait rating, } \\
\text { relative trait } \\
\text { rating }\end{array}$ \\
\hline $\begin{array}{l}\text { Carter \& Dunning } \\
\qquad(2009)\end{array}$ & 5 & $\mathrm{U}$ & $\begin{array}{c}(\mathrm{C} 1) \text { charitable or }(\mathrm{C} 2) \\
\text { Neutral/introverted behaviors }\end{array}$ & A & 2 & 10 & $\begin{array}{l}\text { Self-rated Trait } \\
\text { rating, relative } \\
\text { trait rating }\end{array}$ \\
\hline
\end{tabular}




\begin{tabular}{|c|c|c|c|c|c|c|c|c|c|c|}
\hline $\begin{array}{l}\text { Carter \& Sanna } \\
\qquad(2008)\end{array}$ & 2 & $\mathrm{~J}$ & $\begin{array}{l}\text { (C1) Direct/ }(\mathrm{C} 2) \text { indirect self- } \\
\text { presentation strategies }\end{array}$ & $\mathrm{B}$ & 3 & 12 & $\begin{array}{l}\text { Judgment of } \\
\text { childhood } \\
\text { memory }\end{array}$ & $\mathrm{N}$ & $\begin{array}{l}\mathrm{C} 1: \mathrm{r}=.48 \mathrm{~N}= \\
16, \mathrm{C} 2: \mathrm{r}=.59 \mathrm{~N} \\
\quad=16\end{array}$ & - \\
\hline Caruso (2008) & $1 \mathrm{a}$ & $\mathrm{J}$ & Assertive & A & 2 & 8 & $\begin{array}{c}\text { Self-rated } \\
\text { Assertiveness }\end{array}$ & $\mathrm{N}$ & $\mathrm{r}=.43, \mathrm{~N}=30$ & $\begin{aligned} \mathrm{r} & =-.09, \mathrm{~N} \\
& =30\end{aligned}$ \\
\hline Caruso (2008) & $1 b$ & $\mathrm{~J}$ & Assertive & A & 2 & 8 & $\begin{array}{c}\text { Self-rated } \\
\text { Assertiveness }\end{array}$ & $\mathrm{N}$ & $\mathrm{r}=.13, \mathrm{~N}=57$ & $\begin{aligned} \mathrm{r} & =-.24, \mathrm{~N} \\
& =57\end{aligned}$ \\
\hline Caruso (2008) & 2 & $\mathrm{~J}$ & Creative & A & 2 & 6 & $\begin{array}{l}\text { Self-rated } \\
\text { Creativity }\end{array}$ & $\mathrm{N}$ & $\mathrm{r}=.24, \mathrm{~N}=48$ & $\begin{aligned} r & =-.13, \mathrm{~N} \\
& =47\end{aligned}$ \\
\hline Caruso (2008) & 3 & $\mathrm{~J}$ & Unsafe feeling & A & 2 & 6 & Safety & $\mathrm{N}$ & $\mathrm{r}=.19, \mathrm{~N}=38$ & $\begin{aligned} \mathrm{r} & =-.39, \mathrm{~N} \\
& =38\end{aligned}$ \\
\hline Caruso et al. (2011) & 1 & $\mathrm{U}$ & $\begin{array}{l}\text { examples in which did not have } \\
\text { enough money }\end{array}$ & B & 2 & 6 & $\begin{array}{l}\text { Satisfaction } \\
\text { with personal } \\
\text { finances }\end{array}$ & $\mathrm{N}$ & $\mathrm{r}=.05, \mathrm{~N}=99$ & - \\
\hline Chang (2010) & 1 & $\mathrm{~J}$ & Consequences of disease & A & 2 & 5 & $\begin{array}{c}\text { Perceived } \\
\text { severity }\end{array}$ & $\mathrm{N}$ & $\mathrm{r}=.28 \mathrm{~N}=47$ & - \\
\hline Chang (2010) & 2 & $\mathrm{~J}$ & $\begin{array}{c}\text { Number of ways to prevent } \\
\text { hemorrhoids }\end{array}$ & A & 3 & 7 & $\begin{array}{l}\text { Perceived } \\
\text { efficacy }\end{array}$ & $\mathrm{N}$ & $\mathrm{r}=.21 \mathrm{~N}=95$ & - \\
\hline Chang (2010) & 3 & $\mathrm{~J}$ & $\begin{array}{l}\text { Consequences of disease }(\mathrm{C} 1) \\
\text { solutions }(\mathrm{C} 2) \text { consequences }\end{array}$ & A & 2 & 5 & $\begin{array}{l}\text { Public Service } \\
\text { Announcement } \\
\text { effectiveness }\end{array}$ & $\mathrm{N}$ & $\begin{array}{c}\mathrm{C} 1: \mathrm{r}=.32 \mathrm{~N}= \\
48\end{array}$ & $\begin{array}{l}\mathrm{C} 2: \mathrm{r}= \\
.08 \mathrm{~N}=49\end{array}$ \\
\hline Chang (2010) & 4 & $\mathrm{~J}$ & $\begin{array}{l}\text { Consequences of disease: }(\mathrm{C} 1) \text { tinea } \\
\text { pedis or }(\mathrm{C} 2) \text { peridontal }\end{array}$ & $\mathrm{N}$ & 2 & 5 & $\begin{array}{l}\text { Severity of } \\
\text { disease }\end{array}$ & $\mathrm{N}$ & - & $\begin{array}{c}\mathrm{C} 1: \mathrm{r}= \\
.09 \mathrm{~N}= \\
99.5, \mathrm{C} 2: \mathrm{r} \\
=-.24 \mathrm{~N}= \\
99.5\end{array}$ \\
\hline Cheng (2005) & 3 & $\mathrm{D}$ & $\begin{array}{c}\text { Good things about being an Asian } \\
\text { American }\end{array}$ & $\mathrm{N}$ & 3 & 12 & $\begin{array}{l}\text { attitude towards } \\
\text { being Asian } \\
\text { American }\end{array}$ & $\mathrm{N}$ & $\mathrm{r}=-.17, \mathrm{~N}=108$ & - \\
\hline $\begin{array}{l}\text { Corby \& Homa } \\
\qquad(2011)^{*}\end{array}$ & 1 & $\mathrm{~J}$ & $\begin{array}{l}\text { Recent/childhood examples of } \\
\text { assertive, creative, optimism }\end{array}$ & A & 6 & 12 & Self-rated traits & $\mathrm{N}$ & - & - \\
\hline $\begin{array}{l}\text { Corby \& Homa } \\
(2011)^{*}\end{array}$ & 2 & $\mathrm{~J}$ & $\begin{array}{l}\text { Assertive, friendly, optimism, } \\
\text { creative }\end{array}$ & A & 6 & 12 & Self-rated traits & $\mathrm{N}$ & 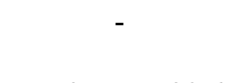 & - \\
\hline $\begin{array}{l}\text { Cutright, Bettman, \& } \\
\text { Fitzsimons (2013) }\end{array}$ & Pilot & $\mathrm{J}$ & $\begin{array}{l}\text { Things in life over which have } \\
\text { complete control }\end{array}$ & $\mathrm{N}$ & 2 & 10 & $\begin{array}{l}\text { Perceptions of } \\
\text { control }\end{array}$ & $\mathrm{N}$ & $\mathrm{r}=.37, \mathrm{~N}=29.6$ & - \\
\hline $\begin{array}{l}\text { Cutright, Bettman, \& } \\
\text { Fitzsimons (2013) }\end{array}$ & 1 & $\mathrm{~J}$ & $\begin{array}{l}\text { Things in life over which have } \\
\text { complete control }\end{array}$ & $\mathrm{N}$ & 2 & 10 & $\begin{array}{l}\text { Perceptions of } \\
\text { control }\end{array}$ & $\mathrm{N}$ & $\mathrm{r}=.38, \mathrm{~N}=59$ & \\
\hline $\begin{array}{l}\text { Danziger, Moran, \& } \\
\text { Rafaely (2006) }\end{array}$ & 1 & $\mathrm{~J}$ & $\begin{array}{l}\text { Reasons in favor of proposal of } \\
\text { changing number of school years in } \\
\text { Israel; }(\mathrm{C} 1, \mathrm{C} 2) \text { high experiential or } \\
(\mathrm{C} 3, \mathrm{C} 4) \text { low experiential }\end{array}$ & $\begin{array}{l}(\mathrm{C} 1, \mathrm{C} 3) \\
\mathrm{B},(\mathrm{C} 2 \\
\mathrm{C} 4) \mathrm{A}\end{array}$ & 2 & 8 & $\begin{array}{c}\text { Evaluation of } \\
\text { proposal to } \\
\text { change number } \\
\text { of school years } \\
\text { in Israel from } 12 \\
\text { to } 11\end{array}$ & $\mathrm{~N}$ & $\begin{array}{c}\mathrm{C} 1: \mathrm{r}=.16 \mathrm{~N}= \\
66, \mathrm{C} 2: \mathrm{r}=.18 \mathrm{~N} \\
=79, \mathrm{C} 3: \mathrm{r}=.25 \\
\mathrm{~N}=84\end{array}$ & $\begin{array}{l}\mathrm{C} 4: \mathrm{r}=- \\
.21, \mathrm{~N}= \\
\quad 75\end{array}$ \\
\hline $\begin{array}{l}\text { DeMarree et al. } \\
\text { (2012) }\end{array}$ & 2 & $\mathrm{~J}$ & $\begin{array}{c}\text { Times tried very hard to achieve } \\
\text { something }\end{array}$ & A & 4 & 10 & $\begin{array}{l}\text { Persistence on } \\
\text { anagrams }\end{array}$ & $\mathrm{N}$ & $\mathrm{r}=.26, \mathrm{~N}=64$ & - \\
\hline
\end{tabular}




\begin{tabular}{|c|c|c|c|c|c|c|c|c|c|c|}
\hline Demotta (2012) & 3 & $\mathrm{D}$ & $\begin{array}{c}\text { Reasons organization was } \\
\text { competent }\end{array}$ & A & 2 & 8 & $\begin{array}{l}\text { Competence of } \\
\text { organization }\end{array}$ & $\mathrm{N}$ & $\mathrm{r}=.28, \mathrm{~N}=128$ & - \\
\hline Deval (2010) & 1 & $\mathrm{D}$ & $\begin{array}{l}\text { Reasons for choosing vacation } \\
\text { package: (C1) on-line + high inv } \\
\text { (C2) memory + low (C3) on-line }+ \\
\text { low }(\mathrm{C} 4) \text { memory + high }\end{array}$ & $\mathrm{N}$ & 2 & 8 & $\begin{array}{l}\text { Attitude towards } \\
\text { vacation } \\
\text { package; } \\
\text { confidence (C1, } \\
\text { C3) }\end{array}$ & $\mathrm{N}$ & $\begin{array}{c}\mathrm{C} 1: \mathrm{r}=.34 \mathrm{~N}= \\
44, \mathrm{C} 2: \mathrm{r}=.36 \mathrm{~N} \\
\quad=41\end{array}$ & $\begin{array}{c}\mathrm{C} 3: \mathrm{r}=- \\
.08 \mathrm{~N}= \\
44, \mathrm{C} 4: \mathrm{r} \\
=-.22 \mathrm{~N}= \\
43\end{array}$ \\
\hline Deval (2010) & 2 & $\mathrm{D}$ & $\begin{array}{l}\text { Reasons for choosing TV }(\mathrm{C} 1) \text { on- } \\
\text { line + high need for closure }(\mathrm{C} 2) \\
\text { memory }+ \text { low }(\mathrm{C} 3) \text { on-line }+ \text { low } \\
\text { (C4) memory + high }\end{array}$ & $\mathrm{N}$ & 1 & 10 & $\begin{array}{l}\text { Attitude towards } \\
\text { 3D HDTV; } \\
\text { confidence (C1, } \\
\text { C3) }\end{array}$ & $\mathrm{N}$ & $\begin{array}{c}\mathrm{C} 1: \mathrm{r}=.35 \mathrm{~N}= \\
46, \mathrm{C} 2: \mathrm{r}=.32 \mathrm{~N} \\
\quad=44\end{array}$ & $\begin{array}{c}\mathrm{C} 3: \mathrm{r}= \\
.14 \mathrm{~N}= \\
42, \mathrm{C} 4: \mathrm{r} \\
=.05 \mathrm{~N}= \\
43\end{array}$ \\
\hline $\begin{array}{l}\text { Dijksterhuis, Macrae, } \\
\text { \& Haddock (1999) }\end{array}$ & 1 & $\mathrm{~J}$ & $\begin{array}{l}\text { Traits on which men and women } \\
\text { reliably differ; (C1) low, (C2) } \\
\text { medium, (C3) high }\end{array}$ & A & 3 & 8 & $\begin{array}{c}\text { Judges' ratings } \\
\text { of } \\
\text { Stereotypicality } \\
\text { in target } \\
\text { portrayals }\end{array}$ & $\mathrm{N}$ & $\begin{array}{c}\mathrm{C} 1: \mathrm{r}=.72, \mathrm{~N}= \\
31\end{array}$ & $\begin{array}{c}\mathrm{C} 2: \mathrm{r}= \\
.46, \mathrm{~N}= \\
31, \mathrm{C} 3: \mathrm{r} \\
=-.50, \mathrm{~N} \\
=31\end{array}$ \\
\hline $\begin{array}{l}\text { Echterhoff \& Hirst } \\
\text { (2006) }\end{array}$ & 1 & $\mathrm{~J}$ & Memory of experiences on NYE & A & 4 & 12 & $\begin{array}{l}\text { Judged memory } \\
\text { quality; } \\
\text { vividness }\end{array}$ & $\mathrm{N}$ & $\mathrm{r}=.32, \mathrm{~N}=93$ & - \\
\hline $\begin{array}{l}\text { Echterhoff \& Hirst } \\
\text { (2006) }\end{array}$ & 2 & $\mathrm{~J}$ & $\begin{array}{c}\text { (C1) no shock, (C2) attenuated } \\
\text { shock, (C3) high shock Memories of } \\
\text { September } 11^{\text {th }}\end{array}$ & A & 4 & 12 & $\begin{array}{l}\text { Judged memory } \\
\text { quality }\end{array}$ & $\mathrm{N}$ & $\begin{array}{c}\mathrm{C} 1: \mathrm{r}=.28 \mathrm{~N}= \\
73, \mathrm{C} 2: \mathrm{r}=.41 \mathrm{~N} \\
\quad=73\end{array}$ & $\begin{array}{l}\mathrm{C} 3: \mathrm{r}=- \\
.07 \mathrm{~N}=69\end{array}$ \\
\hline $\begin{array}{l}\text { Eibach, Libby, \& } \\
\text { Gilovich (2003) }\end{array}$ & 4 & $\mathrm{~J}$ & $\begin{array}{c}\text { Things about you changed since } \\
\text { high school }\end{array}$ & $\mathrm{B}$ & 3 & 12 & $\begin{array}{l}\text { Judgment of } \\
\text { self-change }\end{array}$ & $\mathrm{N}$ & $\mathrm{r}=.33, \mathrm{~N}=80$ & - \\
\hline $\begin{array}{l}\text { Etcheverry, Le, \& } \\
\text { Hoffman (2013) }\end{array}$ & 3 & $\mathrm{~J}$ & Reasons friend is satisfied & $\mathrm{B}$ & 3 & 8 & $\begin{array}{l}\text { Level of } \\
\text { approval; } \\
\text { perceived } \\
\text { relationship } \\
\text { satisfaction }\end{array}$ & $\mathrm{N}$ & $\mathrm{r}=.32, \mathrm{~N}=44$ & - \\
\hline $\begin{array}{l}\text { Florack \& Zoabi } \\
\qquad(2003)^{*}\end{array}$ & 1 & $\mathrm{~J}$ & Reasons for/against investment & $\mathrm{N}$ & 1 & 3 & $\begin{array}{l}\text { Willingness to } \\
\text { invest }\end{array}$ & $\mathrm{N}$ & - & - \\
\hline $\begin{array}{l}\text { Florack \& Zoabi } \\
\qquad(2003)^{*}\end{array}$ & 2 & $\mathrm{~J}$ & Reasons for/against investment & A & 1 & 3 & $\begin{array}{l}\text { Willingness to } \\
\text { invest }\end{array}$ & $\mathrm{N}$ & - & - \\
\hline Fox (2006) & 1 & $\mathrm{~J}$ & $\begin{array}{c}\text { Ways in which course could be } \\
\text { improved }\end{array}$ & $\mathrm{N}$ & 2 & 10 & Course Ratings & $\mathrm{N}$ & $\mathrm{r}=.28, \mathrm{~N}=58$ & - \\
\hline $\begin{array}{l}\text { Gawronski, } \\
\text { Bodenhausen, \& } \\
\text { Banse (2005) }\end{array}$ & 4 & $\mathrm{~J}$ & $\begin{array}{c}\text { (C1) Introverted/ (C2) extroverted } \\
\text { exemplars }\end{array}$ & $\mathrm{N}$ & 3 & 10 & $\begin{array}{l}\text { Outgroup } \\
\text { extroversion }\end{array}$ & $\mathrm{N}$ & $\begin{array}{c}\mathrm{C} 1: \mathrm{r}=.50 \mathrm{~N}= \\
16, \mathrm{C} 2: \mathrm{r}=.49 \mathrm{~N} \\
=16\end{array}$ & - \\
\hline $\begin{array}{l}\text { Gawronski, } \\
\text { Bodenhausen, \& } \\
\text { Banse (2005) }\end{array}$ & 5 & $\mathrm{~J}$ & $\begin{array}{l}\text { Students high in (C1) introversion/ } \\
\text { (C2) extroversion }\end{array}$ & A & 3 & 10 & $\begin{array}{l}\text { Ingroup } \\
\text { Extroversion; } \\
\text { outgroup } \\
\text { extraversion }\end{array}$ & $\mathrm{N}$ & $\begin{array}{c}\mathrm{C} 1: \mathrm{r}=.21 \mathrm{~N}= \\
35, \mathrm{C} 2: \mathrm{r}=.29 \mathrm{~N} \\
\quad=35\end{array}$ & - \\
\hline
\end{tabular}




\begin{tabular}{|c|c|c|}
\hline Gomillion (2012) & 1 & $\mathrm{U}$ \\
\hline $\begin{array}{c}\text { Grayson \& Schwarz } \\
\text { (1999) }\end{array}$ & 1 & $\mathrm{~J}$ \\
\hline $\begin{array}{c}\text { Grayson \& Schwarz } \\
\text { (1999) }\end{array}$ & 2 & $\mathrm{~J}$ \\
\hline $\begin{array}{l}\text { Greifeneder \& Bless } \\
\text { (2007) }\end{array}$ & 1 & $\mathrm{~J}$ \\
\hline $\begin{array}{c}\text { Greifeneder \& Bless } \\
\qquad(2007)\end{array}$ & 2 & $\mathrm{~J}$ \\
\hline $\begin{array}{l}\text { Greifeneder \& Bless } \\
\qquad(2007)\end{array}$ & 3 & $\mathrm{~J}$ \\
\hline $\begin{array}{c}\text { Greifeneder \& Bless } \\
\qquad(2008)\end{array}$ & 1 & $\mathrm{~J}$ \\
\hline $\begin{array}{c}\text { Greifeneder \& Bless } \\
\qquad(2008)\end{array}$ & 2 & $\mathrm{~J}$ \\
\hline $\begin{array}{l}\text { Greifeneder \& Keller } \\
\qquad(2012)\end{array}$ & 1 & $\mathrm{~J}$ \\
\hline $\begin{array}{l}\text { Greifeneder \& Keller } \\
\qquad(2012)\end{array}$ & 2 & $\mathrm{~J}$ \\
\hline $\begin{array}{l}\text { Greifeneder et al. } \\
\qquad(2011 \mathrm{a})\end{array}$ & 1 & $\mathrm{~J}$ \\
\hline $\begin{array}{c}\text { Greifeneder et al. } \\
\text { (2011a) }\end{array}$ & 2 & $\mathrm{~J}$ \\
\hline $\begin{array}{l}\text { Greifeneder et al. } \\
\qquad \text { (2011a) }\end{array}$ & 3 & $\mathrm{~J}$ \\
\hline $\begin{array}{l}\text { Greifeneder et al. } \\
\qquad(2011 \mathrm{~b})\end{array}$ & 1 & $\mathrm{~J}$ \\
\hline
\end{tabular}

Ways in which partner facilitates academic goals

A

4

12

Behaviors that could

increase/decrease risk of assault

Behaviors that could increase risk of assault

Reasons in favor of introduction of new quarterly surgery fee Assertiveness

Reasons in favor of introduction of new quarterly surgery fee

Number of kitchen tools

Reasons in favor of expansion of Mannheim airport

Reasons in favor of airport extension: $(\mathrm{C} 1)$ promotion $(\mathrm{C} 2)$ middle (C3) prevention

Reasons in favor of airport extension (C1) promotion (C2) middle (C3) prevention

Unfair aspects of the university admission process

Unfair aspects about orientation exam for (C1) certain or (C2) uncertain

Unfair aspects about orientation exam $(\mathrm{C} 1)$ certainty $(\mathrm{C} 2)$ control

$$
\text { (C3) uncertainty }
$$

Aspects of trust game seeming unfair as senders (C1) low uncertainty (C2) high uncertainty

\section{Perceived} partner instrumentality; academic ability

$$
\text { test }
$$

Likelihood of

being assaulted

Perceived risk

Evaluation of

surgery fee

Self-rated

Assertiveness

Evaluation of

surgery fee

Evaluation of

kitchen tools

Attitude towards

airport

extension

Evaluation of airport

extension

Evaluation of airport

extension

Procedural

justice; attitude

towards the

$$
\text { ZVS }
$$

Procedural

justice;

organizational

attractiveness

Procedural

justice;

organizational

attractiveness

Fairness

perception

$$
\begin{aligned}
\mathrm{r} & =-.11 \mathrm{~N}=53, \mathrm{r} \\
& =.03 \mathrm{~N}=54
\end{aligned}
$$

$$
\begin{aligned}
& \mathrm{r}=.48 \mathrm{~N}=29 ; \mathrm{r} \quad \mathrm{r}=-.14 \mathrm{~N} \\
& =.21 \mathrm{~N}=29 \quad=30, \mathrm{r}=\text {. } \\
& \mathrm{r}=.29 \mathrm{~N}=30 \quad \mathrm{r}=-.44 \mathrm{~N} \\
& \begin{aligned}
r & =-.44 \\
& =29
\end{aligned} \\
& \mathrm{r}=.24 \mathrm{~N}=43.5 \quad \mathrm{r}=-.19 \mathrm{~N} \\
& \begin{aligned}
\mathrm{r} & =-.19 \mathrm{~N} \\
& =43.5
\end{aligned} \\
& \mathrm{r}=.21 \mathrm{~N}=40 \quad \mathrm{r}=-.39 \mathrm{~N} \\
& \mathrm{C} 1: \mathrm{r}=.28 \mathrm{~N}=\quad \mathrm{C} 2 \mathrm{:} \mathrm{r}=- \\
& 21.5
\end{aligned}
$$

$\mathrm{C} 1: \mathrm{r}=.24 \mathrm{~N}=\quad \mathrm{C} 3: \mathrm{r}=-$ 39.5, $\mathrm{C} 2 \mathrm{:} \mathrm{r}=.11 \quad .09 \mathrm{~N}=$

$$
\mathrm{N}=39.5 \quad 39.5
$$

$\mathrm{C} 1: \mathrm{r}=.33 \mathrm{~N}=\quad \mathrm{C} 3: \mathrm{r}=-$

19.67, C2: $\mathrm{r}=.18 \quad .09 \mathrm{~N}=$

$\mathrm{N}=19.67 \quad 19.67$

$\mathrm{r}=.46 \mathrm{~N}=23$

N

$\mathrm{C} 1: \mathrm{r}=.23 \mathrm{~N}=$ 47.5

C2: $r=$ $.23 \mathrm{~N}=$

47.5

$\mathrm{C} 1: \mathrm{r}=.39 \mathrm{~N}=$ 32.67, $\mathrm{C} 2: \mathrm{r}=.16$

C3: $\mathrm{r}=-$ $.04 \mathrm{~N}=$

$\mathrm{C} 1: \mathrm{r}=.34 \mathrm{~N}=$ 32.67

$\mathrm{N}$ 


\begin{tabular}{|c|c|c|c|c|c|c|c|c|}
\hline $\begin{array}{l}\text { Greifeneder et al. } \\
\qquad(2011 \mathrm{~b})\end{array}$ & 2 & $\mathrm{~J}$ & $\begin{array}{l}\text { Aspects of trust game seeming } \\
\text { unfair as senders }(\mathrm{C} 1) \text { low } \\
\text { uncertainty }(\mathrm{C} 2) \text { high uncertainty }\end{array}$ & A & 1 & 3 & $\begin{array}{l}\text { Trusting } \\
\text { behavior }\end{array}$ & $\mathrm{N}$ \\
\hline Haddock (2002) & 1 & $\mathrm{~J}$ & $\begin{array}{c}\text { Reasons to }(\mathrm{C} 1, \mathrm{C} 3) \text { like/ }(\mathrm{C} 2, \mathrm{C} 4) \\
\text { dislike Tony Blair with }(\mathrm{C} 1, \mathrm{C} 2) \\
\text { low or }(\mathrm{C} 3, \mathrm{C} 4) \text { high interest in } \\
\text { politics }\end{array}$ & A & 2 & 5 & $\begin{array}{l}\text { Evaluation of } \\
\text { Tony Blair }\end{array}$ & $\mathrm{N}$ \\
\hline $\begin{array}{l}\text { Haddock, Rothman, } \\
\text { \& Schwarz (1996) }\end{array}$ & 1 & $\mathrm{~J}$ & $\begin{array}{c}\text { Reasons }(\mathrm{C} 1) \text { for or }(\mathrm{C} 2) \text { against } \\
\text { doctor-assisted suicide }\end{array}$ & A & 3 & 7 & $\begin{array}{l}\text { Attitude } \\
\text { strength }\end{array}$ & $\mathrm{N}$ \\
\hline Haddock et al. (1999) & 1 & $\mathrm{~J}$ & $\begin{array}{l}\text { Reasons }(\mathrm{C} 1, \mathrm{C} 3) \text { for or }(\mathrm{C} 2, \mathrm{C} 4) \\
\text { against doctor-assisted suicide with } \\
\text { moderate }(\mathrm{C} 1, \mathrm{C} 2) \text { or extreme }(\mathrm{C} 3 \text {, } \\
\mathrm{C} 4) \text { attitude }\end{array}$ & A & 3 & 7 & $\begin{array}{l}\text { Attitude } \\
\text { certainty }\end{array}$ & $\mathrm{N}$ \\
\hline Haddock et al. (1999) & 2 & $\mathrm{~J}$ & $\begin{array}{c}\text { Reasons }(\mathrm{C} 1, \mathrm{C} 3) \text { for or }(\mathrm{C} 2, \mathrm{C} 4) \\
\text { against doctor-assisted suicide with } \\
(\mathrm{C} 1, \mathrm{C} 2) \text { high diag or }(\mathrm{C} 3, \mathrm{C} 4) \text { low } \\
\text { diag }\end{array}$ & $\mathrm{A}$ & 3 & 7 & $\begin{array}{l}\text { Attitude } \\
\text { certainty }\end{array}$ & $\mathrm{C} 3 / \mathrm{C} 4$ \\
\hline $\begin{array}{l}\text { Hansen \& Wänke } \\
(2008)\end{array}$ & 2 & $\mathrm{~J}$ & $\begin{array}{l}\text { Arguments against implementation } \\
\text { of federal DNA databases; (C1) } \\
\text { discrepant or (C2) congruent }\end{array}$ & A & 2 & 6 & $\begin{array}{l}\text { Attitude towards } \\
\text { DNA databases }\end{array}$ & $\mathrm{N}$ \\
\hline $\begin{array}{l}\text { Hansen \& Wänke } \\
\text { (2008) }\end{array}$ & 3 & $\mathrm{~J}$ & $\begin{array}{c}(\mathrm{C} 1, \mathrm{C} 3) \text { Pro/ }(\mathrm{C} 2, \mathrm{C} 4) \text { Con for } \\
\text { voting on Internet }\end{array}$ & A & 2 & 8 & $\begin{array}{l}\text { Attitude towards } \\
\text { Internet voting }\end{array}$ & $\mathrm{N}$ \\
\hline $\begin{array}{l}\text { Hermann, } \\
\text { Leonardelli, \& Arkin } \\
(2002)^{*}\end{array}$ & 1 & $\mathrm{~J}$ & $\begin{array}{l}\text { Events in your life that led you to } \\
\text { feel confident about ability to } \\
\text { perform }\end{array}$ & $\mathrm{A}$ & 2 & 8 & Self-esteem & $\mathrm{N}$ \\
\hline $\begin{array}{l}\text { Hermann, } \\
\text { Leonardelli, \& Arkin } \\
\text { (2002)* }\end{array}$ & 2 & $\mathrm{~J}$ & $\begin{array}{l}\text { Events in your life that led you to } \\
\text { feel confident about ability to } \\
\text { perform }\end{array}$ & A & 2 & 12 & Self-esteem & $\mathrm{N}$ \\
\hline $\begin{array}{l}\text { Hermann, } \\
\text { Leonardelli, \& Arkin } \\
(2002)^{*}\end{array}$ & 3 & $\mathrm{~J}$ & $\begin{array}{l}\text { Events in your life that led you to } \\
\text { feel confident about ability to } \\
\text { perform }\end{array}$ & A & 8 & 20 & Self-esteem & $\mathrm{N}$ \\
\hline $\begin{array}{l}\text { Hirt, Kardes, \& } \\
\text { Markman (2004)* }\end{array}$ & 1 & $\mathrm{~J}$ & NFC Teams, Sitcomes & A & 2 & 8 & $\begin{array}{l}\text { Winning } \\
\text { probability }\end{array}$ & $\mathrm{N}$ \\
\hline $\begin{array}{l}\text { IJzerman \& Semin } \\
\qquad(2010)\end{array}$ & 2 & $\mathrm{~J}$ & Similarities & A & 3 & 10 & similarities & $\mathrm{N}$ \\
\hline
\end{tabular}

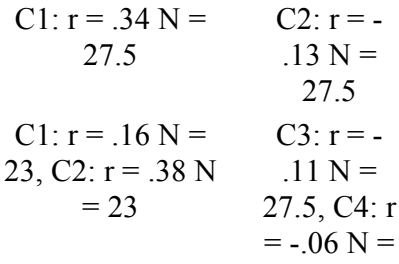




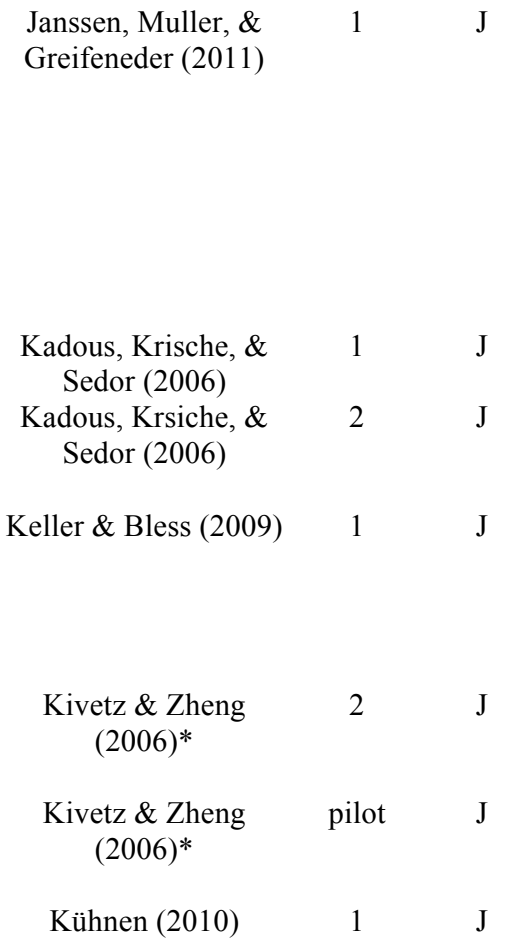

Number of fair aspects of contact with company: (C1) experienced + certain $(\mathrm{C} 2)$ inexperienced +

uncertain $(\mathrm{C} 3)$ inexperienced +

certain (C4) experienced + uncertain

\section{Reasons for failure}

Reasons financial performance might not be as positive

(C1) High faith in intuition, unrelated; (C2) high faith in intuition, related; (C3) low faith in intuition, unrelated; (C4) low faith in intuition, related

Examples in which yielded to vice instead of virtual /overcame a vice for a virtue

Examples in which yielded to vice instead of virtual /overcame a vice for a virtue

Biking instances; (C1) low accuracy

\section{Procedural}

justice

$\mathrm{N}$

$\mathrm{C} 1: \mathrm{r}=.15 \mathrm{~N}=$ 130.75

$\mathrm{C} 2: \mathrm{r}=-$

$.07 \mathrm{~N}=$

130.75,

$\mathrm{C} 3: \mathrm{r}=-$

$.08 \mathrm{~N}=$

130.75,

$\mathrm{C} 4: \mathrm{r}=-$

$.14 \mathrm{~N}=$ 130.75 + manip first, (C2) low accuracy + manip second, (C3) high accuracy + manip first (C4) high accuracy + manip second

Kühnen (2010)

Assertiveness

Kühnen (2010)

Arguments in favor of surgery fee; $(\mathrm{C} 1, \mathrm{C} 2)$ attribution absent, (C3, C4) attribution present

Attributes on which men and women differ

$\begin{array}{cccc}\text { (C1) B, } & 2 & 8 & \begin{array}{c}\text { Self-rated } \\ \text { Assertiveness }\end{array} \\ \text { (C2) A } & & & \text { Attitude towards } \\ \text { surgery fee } \\ \text { (C1, C3) } & 2 & 5 & \\ \text { B, (C2, } & & & \end{array}$

$\mathrm{N}$

$\mathrm{C} 3 / \mathrm{C} 4$

C4) A

\begin{tabular}{|c|c|c|c|}
\hline A & 2 & 12 & Forecasts \\
\hline A & 2 & 10 & Forecasts \\
\hline B & 2,3 & 7,9 & Affect duration \\
\hline $\mathrm{N}$ & 2 & 10 & $\begin{array}{c}\text { Choice of vice } \\
\text { option over } \\
\text { virtue option }\end{array}$ \\
\hline A & 2 & 10 & Feeling guilty \\
\hline $\mathrm{B}, \mathrm{A}$ & 5 & 15 & $\begin{array}{l}\text { Frequency of } \\
\text { biking }\end{array}$ \\
\hline
\end{tabular}

$\mathrm{N}$

$\mathrm{N}$

$\mathrm{N}$ $\mathrm{C} 1: \mathrm{r}=.57, \mathrm{~N}=$

$\mathrm{C} 1: \mathrm{r}=.32 \mathrm{~N}=$
$\begin{gathered}20, \mathrm{C} 2: \mathrm{r}=.44 \mathrm{~N} \\ =26\end{gathered}$

26

$-$

$.20, \mathrm{~N}=39$

-

$3: r=-$ $.02 \mathrm{~N}=$ 27, C4: $\mathrm{r}$ $=.05 \mathrm{~N}=$

24

-

$-$

$\mathrm{C} 2: \mathrm{r}=-$ $.52 \mathrm{~N}=29$ C3: $\mathrm{r}=-$ 27, C4: r $=-.30 \mathrm{~N}=$ 27

$\mathrm{C} 1: \mathrm{r}=.18, \mathrm{~N}=\quad \mathrm{C} 2: \mathrm{r}=-$ $37.5 \quad .30, \mathrm{~N}=$ 29

$\mathrm{C} 1: \mathrm{r}=.46, \mathrm{~N}=\quad \mathrm{C} 2: \mathrm{r}=-$ $24.32, \mathrm{~N}=$ 24, C3: r $=-.32 \mathrm{~N}=$ 23, C4: $\mathrm{r}$ $=-.45, \mathrm{~N}$ $=23$

N
Stereotyping (difference in percentage of

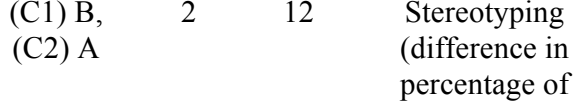

$2: r=-$

$30, \mathrm{~N}=$ 


Kunstman
(2013)

Kunstman et al. (2013)

\begin{tabular}{|c|c|c|}
\hline Laham (2013) & 1 & $\mathrm{~J}$ \\
\hline Laham (2013) & 2 & $\mathrm{~J}$ \\
\hline Lai \& Kuo (2007) & 1 & J \\
\hline Lee (2005) & 2 & $\mathrm{~J}$ \\
\hline $\begin{array}{l}\text { Lemay, Clark, \& } \\
\text { Feeney (2007) }\end{array}$ & 3 & $\mathrm{~J}$ \\
\hline $\begin{array}{l}\text { Menon \& Raghubir } \\
\text { (2003) }\end{array}$ & 1 & $\mathrm{~J}$ \\
\hline $\begin{array}{l}\text { Menon \& Raghubir } \\
\text { (2003) }\end{array}$ & 2 & $\mathrm{~J}$ \\
\hline $\begin{array}{l}\text { Menon \& Raghubir } \\
\text { (2003) }\end{array}$ & 3 & $\mathrm{~J}$ \\
\hline
\end{tabular}

Nonhuman animals they feel
morally obligated to show concer for

\section{Nonhuman animals they feel morally obligated to show concern} for

\section{Piracy-related behaviors \\ Benefits or difficulties of work \\ Things done to help relationship partner in past 7 days \\ Aspects to recall from Micron ad}

Aspects to recall from Micron ad

Aspects to recall from Micron ad;

(C1) task difficult, feedback after;

(C2) task easy, feedback after, (C3)

task easy, feedback before (C4) task difficult, feedback before each sex had

$$
\text { certain }
$$

masculine or

feminine traits)

Florida State

$\mathrm{r}=.33, \mathrm{~N}=35$

connect score

Internal

motivation to

respond without

prejudice;

feelings of

acceptance by

outgroup

Proportion of

world's animals

feel obliged to

show moral

concern for

Proportion of

world's animals

feel obliged to

show moral

concern for

Self-positivity

bias Reduction

\section{Work-life}

conflict

Partner

responsiveness

Recommendatio

necommendatio
n likelihood for

personal

computer brand

Purchase and

recommendatio

$\mathrm{n}$ intention

Purchase and

recommendatio

$\mathrm{n}$ intention $\mathrm{r}=.22, \mathrm{~N}=119$

$\mathrm{r}=.38, \mathrm{~N}=39$

$\mathrm{N}$

$\mathrm{r}=.31, \mathrm{~N}=37$

$\mathrm{C} 1: \mathrm{r}=.52 \mathrm{~N}$

$=30, \mathrm{C} 2 \mathrm{:} \mathrm{r}=.17$ $\mathrm{N}=30$

$\mathrm{r}=.28 \mathrm{~N}=68$

$\mathrm{r}=.17, \mathrm{~N}=15$

$\mathrm{r}=.34, \mathrm{~N}=133$

$\mathrm{C} 1 / \mathrm{C} 4$

$$
\mathrm{C} 1: \mathrm{r}=.13, \mathrm{~N}=
$$$$
46
$$

$\mathrm{C} 1: \mathrm{r}=.35 \mathrm{~N}=$

$26, \mathrm{C} 2: \mathrm{r}=.45 \mathrm{~N}$ $=26, \mathrm{C} 3: \mathrm{r}=.41$

$$
\mathrm{N}=26
$$

C2: $\mathrm{r}=$ -

$38, \mathrm{~N}=$

46

C4: $\mathrm{r}=-$ 


\begin{tabular}{|c|c|c|c|c|c|c|c|c|c|c|}
\hline $\begin{array}{l}\text { Menon \& Raghubir } \\
\text { (2003) }\end{array}$ & 4 & $\mathrm{~J}$ & $\begin{array}{l}\text { Aspects to recall from Micron ad; } \\
\text { (C1) load-difficult, (C2) load-no } \\
\text { info, (C3) no load-difficult }\end{array}$ & A & 4 & 12 & $\begin{array}{l}\text { Purchase and } \\
\text { recommendatio } \\
\mathrm{n} \text { intention }\end{array}$ & $\mathrm{C} 1 / \mathrm{C} 3$ & $\begin{array}{c}\mathrm{C} 1: \mathrm{r}=.35 \mathrm{~N}= \\
36, \mathrm{C} 2: \mathrm{r}=.22, \mathrm{~N} \\
\quad=36\end{array}$ & $\begin{array}{l}\mathrm{C} 3: \mathrm{r}=- \\
45, \mathrm{~N}= \\
16\end{array}$ \\
\hline $\begin{array}{l}\text { Merckelbach et al. } \\
\text { (2001) }\end{array}$ & 1 & $\mathrm{~J}$ & $\begin{array}{c}\text { Negative autobiographical events } \\
\text { before age } 10\end{array}$ & $\mathrm{~N}$ & 3 & 9 & $\begin{array}{l}\text { Agreement that } \\
\text { have repressed } \\
\text { many of their } \\
\text { childhood } \\
\text { memories }\end{array}$ & $\mathrm{N}$ & $\mathrm{r}=-.30, \mathrm{~N}=52$ & - \\
\hline Nestler (2010) & 1 & $\mathrm{~J}$ & Counterfactual thoughts & A & 2 & 10 & $\begin{array}{c}\text { Belief } \\
\text { perseverance }\end{array}$ & $\mathrm{N}$ & $\mathrm{r}=.34, \mathrm{~N}=40$ & - \\
\hline Nestler (2010) & 2 & $\mathrm{~J}$ & Counterfactual thoughts & A & 2 & 10 & $\begin{array}{c}\text { Belief } \\
\text { perseverance }\end{array}$ & $\mathrm{N}$ & $\mathrm{r}=.50, \mathrm{~N}=47$ & - \\
\hline $\begin{array}{l}\text { Novemsky et al. } \\
\text { (2007) }\end{array}$ & 2 & $\mathrm{~J}$ & $\begin{array}{c}\text { Reasons for picking a Microwave } \\
\text { oven or digital camera }\end{array}$ & $\mathrm{B}$ & 2 & 10 & Choice deferral & $\mathrm{N}$ & $\mathrm{r}=.14, \mathrm{~N}=289$ & - \\
\hline $\begin{array}{l}\text { Novemsky et al. } \\
\text { (2007) }\end{array}$ & 3 & $\mathrm{~J}$ & Reasons for picking a camera & B & 2 & 10 & $\begin{array}{l}\text { Compromise } \\
\text { Effect incidence }\end{array}$ & $\mathrm{N}$ & $\mathrm{r}=.27, \mathrm{~N}=180$ & - \\
\hline $\begin{array}{l}\text { Novemsky et al. } \\
\text { (2007) }\end{array}$ & 4 & $\mathrm{~J}$ & $\begin{array}{c}\text { Reasons for picking a Microwave } \\
\text { oven }\end{array}$ & $\mathrm{B}$ & 2 & 10 & $\begin{array}{l}\text { Compromise } \\
\text { Effect incidence }\end{array}$ & $\mathrm{C} 2$ & $\begin{aligned} \mathrm{C} 1: \mathrm{r}= & .25, \mathrm{~N}= \\
& 111\end{aligned}$ & $\begin{array}{c}\mathrm{C} 2: \mathrm{r}=- \\
.20, \mathrm{~N}= \\
111\end{array}$ \\
\hline O’Brien (2013) & 2 & $\mathrm{~J}$ & $\begin{array}{c}\text { (C1) Happy/ (C2) Unhappy } \\
\text { Experiences in Past, (C3) Happy/ } \\
\text { (C4) Unhappy Experiences in Future }\end{array}$ & $\mathrm{B}$ & 3 & 12 & $\begin{array}{c}\text { Future } \\
\text { happiness }\end{array}$ & $\mathrm{N}$ & $\begin{array}{c}\mathrm{C} 1: \mathrm{r}=.37, \mathrm{~N}= \\
45, \mathrm{C} 2: \mathrm{r}=.40 \mathrm{~N} \\
=45, \mathrm{C} 3: \mathrm{r}=.37 \\
\mathrm{~N}=45\end{array}$ & $\begin{array}{l}\mathrm{C} 4: \mathrm{r}= \\
.01, \mathrm{~N}= \\
45\end{array}$ \\
\hline O’Brien (2012) & 1 & $\mathrm{U}$ & $\begin{array}{c}\text { Good aspects of }(\mathrm{C} 1) \text { material/ }(\mathrm{C} 2) \\
\text { experiential good purchase }\end{array}$ & A & 2 & 10 & $\begin{array}{l}\text { Purchase } \\
\text { satisfaction }\end{array}$ & $\mathrm{N}$ & $\begin{array}{c}\mathrm{C} 1: \mathrm{r}=-.03 \mathrm{~N}= \\
69, \mathrm{C} 2: \mathrm{r}=-.003 \\
\mathrm{~N}=59\end{array}$ & - \\
\hline Ofir (2000) & 2 & $\mathrm{~J}$ & $\begin{array}{c}\text { Number of fault reasons; }(\mathrm{C} 1) \text { tree } \\
1,(\mathrm{C} 2) \text { tree } 2,(\mathrm{C} 3) \text { tree } 3\end{array}$ & A & 2 & 5,6 & $\begin{array}{l}\text { Proportion of all } \\
\text { other problems }\end{array}$ & $\mathrm{N}$ & - & - \\
\hline Ofir (2000) & 3 & $\mathrm{~J}$ & $\begin{array}{l}\text { Number of specific failure reasons; } \\
(\mathrm{C} 1) \text { tree } 1 \text {, drivers; }(\mathrm{C} 2) \text { tree } 2, \\
\text { drivers; (C3) tree } 1, \text { mechanics, }(\mathrm{C} 4) \\
\text { tree } 2, \text { mechanics }\end{array}$ & A & 2 & 5 & $\begin{array}{l}\text { Proportion of all } \\
\text { other problems }\end{array}$ & $\mathrm{N}$ & - & - \\
\hline Ofir (2000) & 4 & $\mathrm{~J}$ & Number of specific causal reasons & A & 1 & 6 & $\begin{array}{l}\text { Proportion of all } \\
\text { other problems }\end{array}$ & $\mathrm{N}$ & - & - \\
\hline Ofir et al. (2008) & $1 \mathrm{a}$ & $\mathrm{J}$ & $\begin{array}{c}\text { Number of low-priced products sold } \\
\text { at store }\end{array}$ & A & 2 & 5 & $\begin{array}{l}\text { Store } \\
\text { expensiveness }\end{array}$ & $\mathrm{N}$ & $\mathrm{r}=.54, \mathrm{~N}=99$ & - \\
\hline Ofir et al. (2008) & pilot & $\mathrm{J}$ & $\begin{array}{c}\text { Number of low-priced products sold } \\
\text { at store }\end{array}$ & $\mathrm{A}$ & 2 & 9 & $\begin{array}{l}\text { Store } \\
\text { expensiveness }\end{array}$ & $\mathrm{N}$ & $\mathrm{r}=.39, \mathrm{~N}=134$ & - \\
\hline Ofir et al. (2008) & 2 & $\mathrm{~J}$ & $\begin{array}{l}\text { Number of }(\mathrm{C} 1) \text { low-priced/ }(\mathrm{C} 2) \\
\text { high-priced products sold at store }\end{array}$ & A & 2 & 5 & Price perception & $\mathrm{N}$ & $\begin{array}{c}\mathrm{C} 1: \mathrm{r}=.39 \mathrm{~N}= \\
76, \mathrm{C} 2: \mathrm{r}=.27, \mathrm{~N} \\
\quad=76\end{array}$ & - \\
\hline Ofir et al. (2008) & 3 & $\mathrm{~J}$ & $\begin{array}{c}\text { Number of low-priced products sold } \\
\text { at store }\end{array}$ & A & 2 & 5 & $\begin{array}{l}\text { Store-price } \\
\text { judgment }\end{array}$ & $\mathrm{N}$ & $\mathrm{r}=.43, \mathrm{~N}=51$ & $\begin{aligned} \mathrm{r} & =-.41, \mathrm{~N} \\
& =49\end{aligned}$ \\
\hline
\end{tabular}




\begin{tabular}{|c|c|c|c|c|c|c|c|c|c|c|}
\hline $\begin{array}{l}\text { Oyserman, Fryberg, } \\
\text { \& Yoder (2007) }\end{array}$ & 5 & $\mathrm{~J}$ & Ways group and Whites are similar & $\mathrm{N}$ & 3 & 8 & $\begin{array}{c}\text { Self-rated } \\
\text { Similarity to } \\
\text { Whites }\end{array}$ & $\mathrm{N}$ & $\mathrm{r}=.32, \mathrm{~N}=38.67$ & - \\
\hline $\begin{array}{l}\text { Oyserman, Fryberg, } \\
\text { \& Yoder (2007) }\end{array}$ & 6 & $\mathrm{~J}$ & Ways group and Whites are similar & $\mathrm{N}$ & 3 & 8 & $\begin{array}{l}\text { Similarity to } \\
\text { Whites }\end{array}$ & $\mathrm{N}$ & $\mathrm{r}=.29, \mathrm{~N}=40$ & - \\
\hline $\begin{array}{l}\text { Oyserman, Fryberg, } \\
\text { \& Yoder (2007) }\end{array}$ & 7 & $\mathrm{~J}$ & Ways group and Whites are similar & $\mathrm{N}$ & 3 & 8 & $\begin{array}{l}\text { Similarity to } \\
\text { Whites }\end{array}$ & $\mathrm{N}$ & $\mathrm{r}=.29, \mathrm{~N}=68$ & - \\
\hline Pahl \& Eiser (2007) & 1 & $\mathrm{~J}$ & $\begin{array}{l}\text { Behaviors }(\mathrm{C} 1) \text { you / }(\mathrm{C} 2) \text { a typical } \\
\text { student does in a typical week that } \\
\text { may be harmful to environment }\end{array}$ & A & 2 & 8 & $\begin{array}{l}\text { Comparative } \\
\text { self-positivity }\end{array}$ & $\mathrm{N}$ & $\begin{array}{l}\mathrm{C} 1: \mathrm{r}=.06 \mathrm{~N}= \\
49.5, \mathrm{C} 2: \mathrm{r}=.23 \\
\mathrm{~N}=49.5\end{array}$ & - \\
\hline Park (2004) & 1 & $\mathrm{D}$ & $\begin{array}{c}\text { Reason for purchase (C1) } \\
\text { compatible prevention (C2) } \\
\text { compatible promotion (C3) } \\
\text { incompatible prevention (C4) } \\
\text { incompatible promotion }\end{array}$ & A & 1 & 10 & $\begin{array}{l}\text { Product } \\
\text { Evaluation }\end{array}$ & $\mathrm{N}$ & $\begin{array}{c}\mathrm{C} 1: \mathrm{r}=.40 \mathrm{~N}= \\
26.25, \mathrm{C} 2: \mathrm{r}=.39 \\
\mathrm{~N}=26.25\end{array}$ & $\begin{array}{l}\mathrm{C} 3: \mathrm{r}=- \\
.35 \mathrm{~N}= \\
26.25, \mathrm{C} 4: \\
\mathrm{r}=-.30 \mathrm{~N} \\
=26.25\end{array}$ \\
\hline Park (2004) & 2 & $\mathrm{D}$ & $\begin{array}{c}\text { Reason for purchase }(\mathrm{C} 1) \\
\text { compatible interdependent }(\mathrm{C} 2) \\
\text { compatible independent }(\mathrm{C} 3) \\
\text { incompatible interdependent }(\mathrm{C} 4) \\
\text { incompatible independent }\end{array}$ & A & 1 & 10 & $\begin{array}{l}\text { Product } \\
\text { Evaluation }\end{array}$ & $\mathrm{N}$ & $\begin{array}{c}\mathrm{C} 1: \mathrm{r}=.18 \mathrm{~N}= \\
34.25, \mathrm{C} 2: \mathrm{r}=.57 \\
\mathrm{~N}=34.25\end{array}$ & $\begin{array}{l}\mathrm{C} 3: \mathrm{r}=- \\
.48 \mathrm{~N}= \\
34.25, \mathrm{C} 4: \\
\mathrm{r}=-.42 \mathrm{~N} \\
=34.25\end{array}$ \\
\hline $\begin{array}{l}\text { Petrocelli \& Dowd } \\
\text { (2009) }\end{array}$ & 3 & $\mathrm{~J}$ & If-only statements & A & 4 & 10 & $\begin{array}{l}\text { Severity of } \\
\text { punishment; } \\
\text { deservingness of } \\
\text { punishment; } \\
\text { causality }\end{array}$ & $\mathrm{N}$ & $\mathrm{r}=.27, \mathrm{~N}=49$ & $\begin{aligned} \mathrm{r}= & -.20, \mathrm{~N} \\
& =49\end{aligned}$ \\
\hline $\begin{array}{l}\text { Pocheptsova, Labroo, } \\
\text { \& Dhar (2010) }\end{array}$ & 2 & $\mathrm{~J}$ & $\begin{array}{l}\text { Reasons to go to a (C1) causal or } \\
\text { (C2) fancy restaurant }\end{array}$ & A & 1 & 5 & $\begin{array}{l}\text { Willingness-to- } \\
\text { pay }\end{array}$ & $\mathrm{N}$ & $\begin{array}{c}\mathrm{C} 1: \mathrm{r}=.10 \mathrm{~N}= \\
102.5, \mathrm{C} 2: \mathrm{r}=.33 \\
\mathrm{~N}=102.5\end{array}$ & - \\
\hline $\begin{array}{l}\text { Preston \& Epley } \\
\quad(2005)\end{array}$ & 3 & $\mathrm{~J}$ & $\begin{array}{l}\text { Observations that }(\mathrm{C} 1) \text { God can } \\
\text { explain, }(\mathrm{C} 2) \text { observations that can } \\
\text { explain God's behavior }\end{array}$ & $\mathrm{N}$ & 3 & 10 & $\begin{array}{l}\text { Perceived value } \\
\text { of Belief in God }\end{array}$ & $\mathrm{N}$ & - & $\begin{array}{l}\mathrm{C} 1: \mathrm{r}=- \\
.20 \mathrm{~N}= \\
28.5, \mathrm{C} 2: \mathrm{r} \\
=-.04 \mathrm{~N}= \\
\quad 28.5\end{array}$ \\
\hline $\begin{array}{l}\text { Raghubir \& Menon } \\
\text { (1998) }\end{array}$ & 2 & $\mathrm{~J}$ & AIDS-related behaviors (Self) & A & 3 & 5 & Risk of AIDS & $\mathrm{N}$ & $\mathrm{r}=.27, \mathrm{~N}=50$ & - \\
\hline $\begin{array}{l}\text { Raghubir \& Menon } \\
\qquad(1998)\end{array}$ & 3 & $\mathrm{~J}$ & Ways in which HIV is transmitted & A & 1 & 3 & Risk of AIDS & $\mathrm{N}$ & $\mathrm{r}=.30, \mathrm{~N}=61$ & - \\
\hline $\begin{array}{l}\text { Raghubir \& Menon } \\
\qquad(2005)\end{array}$ & 1 & $\mathrm{~J}$ & $\begin{array}{l}\text { (C1) Positive/ (C2) Negative } \\
\text { experiences eating out }\end{array}$ & A & 2 & 8 & $\begin{array}{l}\text { Satisfaction } \\
\text { with eating-out } \\
\text { experiences; } \\
\text { open-ended } \\
\text { frequency, } \\
\text { close-ended } \\
\text { frequency, }\end{array}$ & $\mathrm{N}$ & $\begin{array}{c}\mathrm{C} 1: \mathrm{r}=.23 \mathrm{~N}= \\
47, \mathrm{C} 2: \mathrm{r}=.31 \mathrm{~N} \\
\quad=47\end{array}$ & - \\
\hline
\end{tabular}




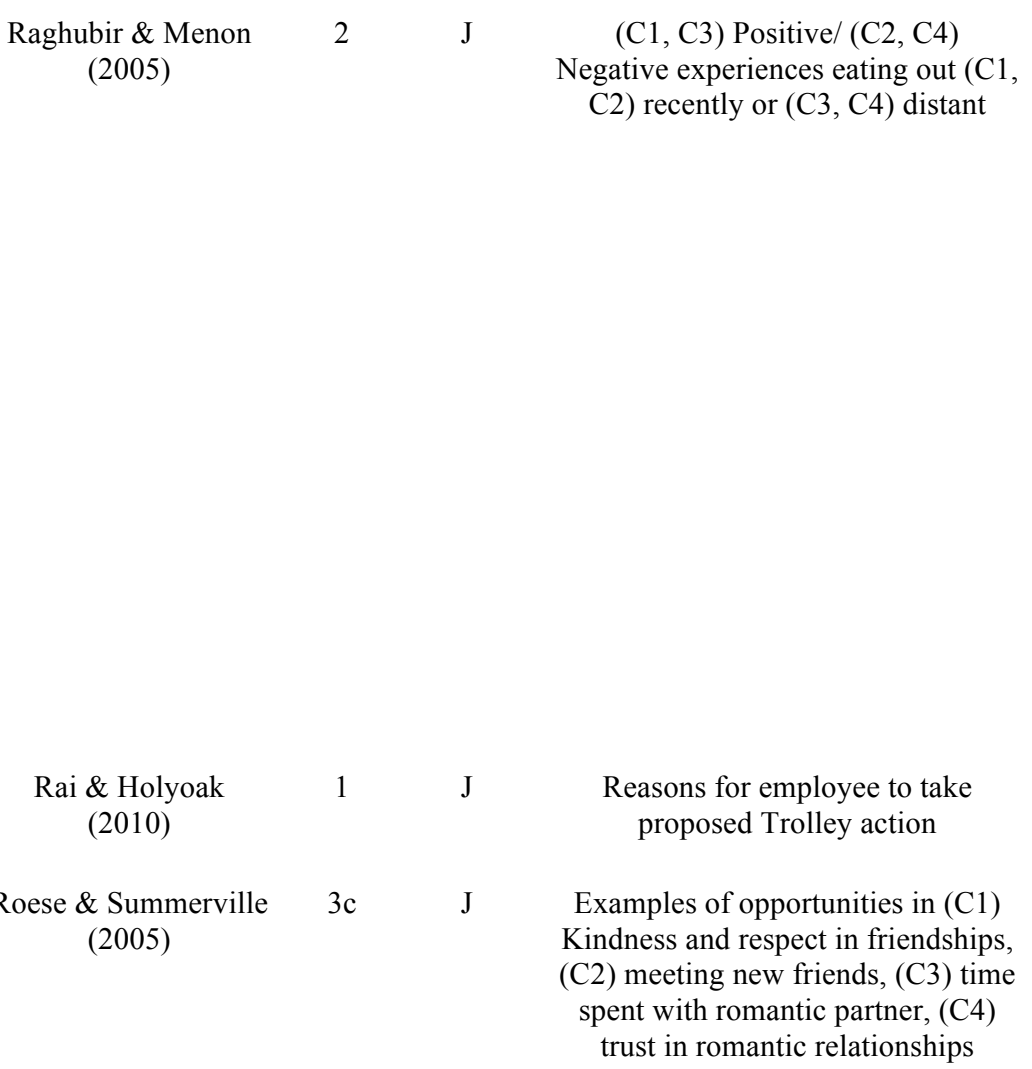

J

(n)

(C1, C3) Positive/ (C2, C4)

Negative experiences eating out $(\mathrm{C} 1$,

$\mathrm{C} 2)$ recently or $(\mathrm{C} 3, \mathrm{C} 4)$ distant

Kindness and respect in friendships,

(C2) meeting new friends, (C3) time

spent with romantic partner, $(\mathrm{C} 4)$

trust in romantic relationships

A

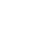$$
\text { w }
$$

\section{dollars spent \\ eating out,}

attitude towards

eating out,

likelihood of

initiating next

eating out,

likelihood of

positive

experience,

likelihood of

negative

experience

Satisfaction

with eating-out

experiences

open-ended

frequency,

close-ended

frequency,

dollars spent

eating out - sit-

down, dollars

spent eating out

fast-food,

attitude towards

eating out,

likelihood of

initiating next eating out,

likelihood of sitdown,

likelihood of

fast-food

$$
\text { (1997) }
$$

Agreement with

taking proposed action

Self-rated

N

A

polite ratings

$\mathrm{C} 1: \mathrm{r}=.39 \mathrm{~N}=$ 41.75, C2: $\mathrm{r}=.31$ $\mathrm{N}=41.75$

$r=$ $.002 \mathrm{~N}=$ 41.75, C4: $\mathrm{r}=-.05 \mathrm{~N}$ $=41.75$

$\mathrm{C} 1: \mathrm{r}=.01 \mathrm{~N}=$ $60, \mathrm{C} 2: \mathrm{r}=.21 \mathrm{~N}$ $=42, \mathrm{C} 3: \mathrm{r}=-.22$ $\mathrm{N}=50, \mathrm{C} 4: \mathrm{r}=$ $.01 \mathrm{~N}=46$

$\mathrm{r}=.25, \mathrm{~N}=54$ N 


\begin{tabular}{|c|c|c|c|c|c|c|c|c|c|c|}
\hline $\begin{array}{l}\text { Rothman \& Hardin } \\
\text { (1997) }\end{array}$ & 2 & $\mathrm{~J}$ & Assertive/Unassertive & A & 3 & 6 & $\begin{array}{c}\text { Self-rated } \\
\text { Assertiveness }\end{array}$ & $\mathrm{C} 3 / \mathrm{C} 4$ & $\begin{array}{l}\mathrm{C} 1: \mathrm{r}=.11, \mathrm{~N}= \\
20.75 ; \mathrm{C} 2: \mathrm{r}= \\
.21, \mathrm{~N}=20.75\end{array}$ & $\begin{array}{c}\mathrm{C} 3: \mathrm{r}=- \\
.28, \mathrm{~N}= \\
42.50 ; \mathrm{C} 4: \\
\mathrm{r}=-.17, \mathrm{~N} \\
=42.50 ; \\
\mathrm{C} 5: \mathrm{r}=- \\
.14, \mathrm{~N}= \\
20.75 ; \mathrm{C} 6: \\
\mathrm{r}=-.23, \mathrm{~N} \\
=20.75\end{array}$ \\
\hline $\begin{array}{l}\text { Rothman \& Hardin } \\
\text { (1997) }\end{array}$ & 3 & $\mathrm{~J}$ & Assertive/Unassertive & A & 3 & 6 & $\begin{array}{c}\text { Self-rated } \\
\text { Assertiveness }\end{array}$ & $\mathrm{N}$ & $\begin{aligned} \mathrm{r} & =.12, \mathrm{~N}=58 ; \mathrm{r} \\
& =.13, \mathrm{~N}=63\end{aligned}$ & $\begin{array}{l}\mathrm{r}=-.17, \mathrm{~N} \\
=58 ; \mathrm{r}=- \\
.23, \mathrm{~N}= \\
63\end{array}$ \\
\hline $\begin{array}{l}\text { Rothman \& Schwarz } \\
\text { (1998) }\end{array}$ & 1 & $\mathrm{~J}$ & $\begin{array}{c}\text { Risk-increasing/decreasing factors } \\
\text { for self/avg. man (C1) family history } \\
+ \text { avg man }+ \text { decr }(\mathrm{C} 2) \text { family } \\
\text { history }+ \text { avg man }+ \text { incr }(\mathrm{C} 3) \text { no } \\
\text { family }+ \text { self }+ \text { decr }(\mathrm{C} 4) \text { no family } \\
+ \text { self }+ \text { incr }(\mathrm{C} 5) \text { no family }+ \text { avg }+ \\
\text { decr }(\mathrm{C} 6) \text { no family }+ \text { avg }+ \text { incr } \\
\text { (C7) family }+ \text { self }+ \text { decr }(\mathrm{C} 8) \\
\text { family }+ \text { self }+ \text { incr }\end{array}$ & A & 3 & 8 & Risk Perception & $\mathrm{N}$ & $\begin{array}{c}\mathrm{C} 1: \mathrm{r}=.38 \mathrm{~N}= \\
18, \mathrm{C} 2: \mathrm{r}=.59 \mathrm{~N} \\
=20, \mathrm{C} 3: \mathrm{r}=.42 \\
\mathrm{~N}=19, \mathrm{C} 4: \mathrm{r}= \\
.28 \mathrm{~N}=17\end{array}$ & $\begin{array}{c}\mathrm{C} 5: \mathrm{r}= \\
.10 \mathrm{~N}= \\
21, \mathrm{C} 6: \mathrm{r} \\
=-.28 \mathrm{~N}= \\
18, \mathrm{C} 7: \mathrm{r} \\
=-.55 \mathrm{~N}= \\
20, \mathrm{C} 8: \mathrm{r} \\
=-.22 \mathrm{~N}= \\
23\end{array}$ \\
\hline Ruder \& Bless (2003) & 1 & $\mathrm{~J}$ & $\begin{array}{l}\text { Arguments in favor of reduction in } \\
\text { number of years of education }\end{array}$ & $\mathrm{B}$ & 2 & 6 & $\begin{array}{l}\text { Agreement with } \\
\text { policy for } \\
\text { change in } \\
\text { education } \\
\text { system }\end{array}$ & $\mathrm{N}$ & $\mathrm{r}=.61 \mathrm{~N}=24$ & $\begin{array}{c}\mathrm{r}=-.33 \mathrm{~N} \\
=26\end{array}$ \\
\hline Ruder \& Bless (2003) & 3 & $\mathrm{~J}$ & $\begin{array}{l}\text { Reasons against highway toll; }(\mathrm{C} 1) \\
\text { happy }+ \text { diagnostic }(\mathrm{C} 2) \text { sad }+ \\
\text { nondiagnostic }(\mathrm{C} 3) \text { sad }+ \text { diagnostic } \\
\text { (C4) happy }+ \text { nondiagnostic }\end{array}$ & $\mathrm{B}$ & 2 & 5 & $\begin{array}{l}\text { Agreement with } \\
\text { policy for } \\
\text { highway toll }\end{array}$ & $\mathrm{C} 2 / \mathrm{C} 4$ & $\begin{array}{c}\mathrm{C} 1: \mathrm{r}=.37 \mathrm{~N}= \\
27.5\end{array}$ & $\begin{array}{c}\mathrm{C} 2: \mathrm{r}=- \\
.49 \mathrm{~N}= \\
27.5, \mathrm{C} 3: \mathrm{r} \\
=-.51 \mathrm{~N}= \\
27.5, \mathrm{C} 4: \mathrm{r} \\
=-.46 \mathrm{~N}= \\
27.5\end{array}$ \\
\hline Ruder \& Bless (2003) & 4 & $\mathrm{~J}$ & $\begin{array}{l}\text { Arguments in favor of reduction in } \\
\text { number of years of education }\end{array}$ & $\mathrm{B}$ & 2 & 5 & $\begin{array}{l}\text { Agreement with } \\
\text { policy for } \\
\text { highway toll }\end{array}$ & $\mathrm{N}$ & $\mathrm{r}=.41 \mathrm{~N}=31.5$ & $\begin{aligned} \mathrm{r} & =-.29 \mathrm{~N} \\
& =31.5\end{aligned}$ \\
\hline Ruder \& Bless (2003) & $\mathrm{F}$ & $\mathrm{J}$ & $\begin{array}{l}\text { Arguments in favor of reduction in } \\
\text { number of years of education }\end{array}$ & $\mathrm{B}$ & 2 & 6 & $\begin{array}{l}\text { Agreement with } \\
\text { policy for } \\
\text { change in } \\
\text { education } \\
\text { system }\end{array}$ & $\mathrm{N}$ & $\mathrm{r}=.43, \mathrm{~N}=24$ & - \\
\hline
\end{tabular}




\begin{tabular}{|c|c|c|c|c|c|c|c|c|c|c|}
\hline Sackett $(2006)^{*}$ & 6 & $\mathrm{D}$ & $\begin{array}{c}\text { Advantages/disadvantages of } \\
\text { optimistic or pessimistic prediction } \\
\text { errors }\end{array}$ & $\mathrm{N}$ & 2 & 8 & $\begin{array}{l}\text { Preferences for } \\
\text { predictions }\end{array}$ & $\mathrm{N}$ & - & - \\
\hline $\begin{array}{l}\text { Sanna, Chang, \& } \\
\text { Carter (2004) }\end{array}$ & 3 & $\mathrm{~J}$ & $\begin{array}{c}\text { Thoughts about }(\mathrm{C} 1) \text { outcome/ }(\mathrm{C} 2) \\
\text { alternative }\end{array}$ & B & 2 & 10 & $\begin{array}{c}\text { outcome } \\
\text { inevitability }\end{array}$ & $\mathrm{N}$ & $\begin{array}{c}\mathrm{C} 1: \mathrm{r}=.48 \mathrm{~N}= \\
20, \mathrm{C} 2: \mathrm{r}=.58 \mathrm{~N} \\
\quad=20\end{array}$ & - \\
\hline $\begin{array}{l}\text { Sanna, Parks, Chang, } \\
\text { \& Carter (2005) }\end{array}$ & 3 & $\mathrm{~J}$ & $\begin{array}{l}\text { Reasons for }(\mathrm{C} 1) \text { successful/ (C2) } \\
\text { unsuccessful task completion }\end{array}$ & $\mathrm{B}$ & 5 & 15 & $\begin{array}{l}\text { difference in } \\
\text { completion time }\end{array}$ & $\mathrm{N}$ & $\begin{array}{c}\mathrm{C} 1: \mathrm{r}=.50 \mathrm{~N}= \\
20, \mathrm{C} 2: \mathrm{r}=.55 \mathrm{~N} \\
=20\end{array}$ & - \\
\hline $\begin{array}{l}\text { Sanna, Schwarz, \& } \\
\text { Small (2002) }\end{array}$ & 1 & $\mathrm{~J}$ & $\begin{array}{c}\text { Thoughts that would have helped } \\
\text { side win; (C1) G win, (C2) British } \\
\text { win }\end{array}$ & A & 2 & 10 & $\begin{array}{c}\text { Probability } \\
\text { judgment }\end{array}$ & $\mathrm{N}$ & $\begin{array}{c}\mathrm{C} 1: \mathrm{r}=.45 \mathrm{~N}= \\
28, \mathrm{C} 2: \mathrm{r}=.57 \mathrm{~N} \\
\quad=29\end{array}$ & - \\
\hline $\begin{array}{l}\text { Sanna, Schwarz, \& } \\
\text { Stocker (2002) }\end{array}$ & 1 & $\mathrm{~J}$ & Thoughts of other outcomes & $\mathrm{N}$ & 2 & 10 & $\begin{array}{l}\text { Probability of } \\
\text { other outcome }\end{array}$ & $\mathrm{N}$ & $\mathrm{r}=.51, \mathrm{~N}=34$ & - \\
\hline $\begin{array}{l}\text { Sanna, Schwarz, \& } \\
\text { Stocker (2002) }\end{array}$ & 2 & $\mathrm{~J}$ & Thoughts of other outcomes & A & 2 & 10 & $\begin{array}{l}\text { Probability of } \\
\text { other outcome }\end{array}$ & $\mathrm{N}$ & $\mathrm{r}=.49, \mathrm{~N}=40$ & - \\
\hline $\begin{array}{l}\text { Sanna \& Schwarz } \\
\text { (2003) }\end{array}$ & 1 & $\mathrm{~J}$ & $\begin{array}{l}\text { Thoughts about how homecoming } \\
\text { game might have turned out } \\
\text { differently }\end{array}$ & $\mathrm{B}$ & 4 & 12 & $\begin{array}{c}\text { Difference } \\
\text { between actual } \\
\text { and predicted }\end{array}$ & $\mathrm{C} 2$ & $\begin{array}{l}\mathrm{C} 1: \mathrm{r}=.57, \mathrm{~N}= \\
25\end{array}$ & $\begin{array}{c}\mathrm{C} 2: \mathrm{r}=- \\
21, \mathrm{~N}= \\
28\end{array}$ \\
\hline $\begin{array}{l}\text { Sanna \& Schwarz } \\
\text { (2004) }\end{array}$ & 1 & $\mathrm{~J}$ & $\begin{array}{l}\text { Things that might lead you to do } \\
\text { well on exam }\end{array}$ & B & 3 & 12 & $\begin{array}{l}\text { Study } \\
\text { Completion, } \\
\text { Success } \\
\text { Likelihood }\end{array}$ & $\mathrm{N}$ & - & - \\
\hline Scarnier (2007) & 2 & $\mathrm{D}$ & Times controlled child's behavior & A & 2 & 8 & $\begin{array}{l}\text { Control (over } \\
\text { ability to } \\
\text { influence child's } \\
\text { behavior, other } \\
\text { individuals can } \\
\text { control their } \\
\text { children better) }\end{array}$ & $\mathrm{N}$ & $\mathrm{r}=.01, \mathrm{~N}=124$ & - \\
\hline Shockley (2013) & 7 & $\mathrm{D}$ & $\begin{array}{l}\text { Times things went well when stuck } \\
\text { with tradition or routine }\end{array}$ & $\mathrm{N}$ & 2 & 6 & $\begin{array}{l}\text { Resistance to } \\
\text { Change Scale; } \\
\text { feelings of } \\
\text { sticking with } \\
\text { tradition }\end{array}$ & $\mathrm{N}$ & $\mathrm{r}=.05, \mathrm{~N}=47$ & - \\
\hline Schwarz et al. (1991) & 1 & $\mathrm{~J}$ & $\begin{array}{l}\text { (C1) Assertive } \\
\text { (C2) Unassertive }\end{array}$ & A & 6 & 12 & $\begin{array}{c}\text { Self-rated } \\
\text { Assertiveness }\end{array}$ & $\mathrm{N}$ & $\begin{array}{c}\mathrm{C} 1: \mathrm{r}=.35 \mathrm{~N}= \\
20 \\
\mathrm{C} 2: \mathrm{r}=.66, \mathrm{~N}= \\
20\end{array}$ & - \\
\hline Schwarz et al. (1991) & 2 & $\mathrm{~J}$ & $\begin{array}{l}\text { (C1) Assertive } \\
\text { (C2) Unassertive }\end{array}$ & A & 6 & 12 & $\begin{array}{c}\text { Self-rated } \\
\text { Assertiveness }\end{array}$ & $\mathrm{N}$ & $\begin{array}{c}\mathrm{C} 1: \mathrm{r}=.17 \mathrm{~N}= \\
\quad 79 \\
\mathrm{C} 2: \mathrm{r}=.21, \mathrm{~N}= \\
\quad 79\end{array}$ & - \\
\hline
\end{tabular}




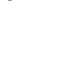

12

Self-rated

Assertiveness

$\mathrm{C} 3 / \mathrm{C} 4$

Silvera et al. (2005)

Simonsohn,

Simmons, \& Nelson

$$
\text { (2011) }
$$

Sinclair \& Carlsson

Sinha \&

Naykankuppam

(2013)

Sinha \&

Naykankuppam

(2013)

Sinha \&

Naykankuppam

(2013)

\section{Spielmann, \\ MacDonald, \& \\ Wilson (2009)}

Stephens (2007)

Stocker (2006)

Stone \& Fernandez

$$
\text { (2011) }
$$

Thorisdottir \& Jost
C4) Thoughts about my (C1, C2) or others' $(\mathrm{C} 3, \mathrm{C} 4)$ relationships

\section{Categories of potential causes of} failure

\section{(C1) Assertive/ (C2) Unassertive}

Typical things done for boys/girls, things done where felt capable

Tourist spots in England

Company that makes digital cameras

Painters

People within their social networks with whom they could imagine developing a relationship

Behaviors associated with $(\mathrm{C} 1) \mathrm{AD}$

$$
\text { (C2) HR }
$$

\section{Distinct times in last year when} spent time in sun but did not wear

Instances in which they felt threatened
Likelihood of

all other

problems

Self-rated

Assertiveness

\section{Occupationa}

preference

Willingness-to-

pay for trip

Purchase

likelihood

Willingness-to-

pay

Emotional

attachment to

ex-partner

Likelihood

difference score

Modified

Investment

Model Scale

Sunscreen

acquisition

Threatened
feeling
$\mathrm{C} 1: \mathrm{r}=.33 \mathrm{~N}=$ 19.5

$\mathrm{C} 2: \mathrm{r}=.39, \mathrm{~N}=$

19.5

$.28 \mathrm{~N}=$

19.5,

C4: $\mathrm{r}=-$

$.33, \mathrm{~N}=$

19.5

$\mathrm{r}=.28, \mathrm{~N}=76 \quad \mathrm{r}=-.19, \mathrm{~N}$

$=86$

$\mathrm{C} 1: \mathrm{r}=-.13 \mathrm{~N}=$

24, $\mathrm{C} 2: \mathrm{r}=-.20 \mathrm{~N}$

$=22$

$\mathrm{r}=.13, \mathrm{~N}=85 ; \mathrm{r}$

$=-.28, \mathrm{~N}=73 ; \mathrm{r}$

$=.06, \mathrm{~N}=59 ; \mathrm{r}=$

$.004, \mathrm{~N}=54$

$r=.44, N=47.33 \quad r=-.32, N$

$=47.33$

$\mathrm{r}=.46, \mathrm{~N}=36 ; \mathrm{r} \quad \mathrm{r}=-.11, \mathrm{~N}$

$=.50, \mathrm{~N}=36 \quad=36 ; \mathrm{r}=$

$.58, \mathrm{~N}=$

36

$\mathrm{r}=.50, \mathrm{~N}=\quad \mathrm{r}=-.55, \mathrm{~N}$

$44.50 ; \mathrm{r}=.50, \mathrm{~N} \quad=44.50 ; \mathrm{r}$

$=44.50 \quad=-.05, \mathrm{~N}$

$=28 \mathrm{~N}=40.5 \quad=44.50$

$=40.5$

$\mathrm{C} 1: \mathrm{r}=.14 \mathrm{~N}=$

$59, \mathrm{C} 2: \mathrm{r}=.02 \mathrm{~N}$ $=60$

$\mathrm{C} 1: \mathrm{r}=-.02, \mathrm{~N}=$

48.5; $\mathrm{C} 2: \mathrm{r}=.27$,

$\mathrm{N}=48.5$; $\mathrm{C} 3: \mathrm{r}=$

$.11, \mathrm{~N}=48.5 ; \mathrm{C} 4$ :

$\mathrm{r}=.08, \mathrm{~N}=48.50$

$\mathrm{r}=.37 \mathrm{~N}=45$ 


\begin{tabular}{|c|c|c|c|c|c|c|c|c|c|c|}
\hline Thorisdottir \& Jost & $1 b$ & $\mathrm{~J}$ & $\begin{array}{c}\text { Instances in which they felt } \\
\text { threatened }\end{array}$ & $\mathrm{N}$ & 3 & 12 & perceived threat & $\mathrm{N}$ & - & $\begin{aligned} r & =-.26, \mathrm{~N} \\
& =50\end{aligned}$ \\
\hline $\begin{array}{l}\text { Tormala, Petty, \& } \\
\text { Brinol (2002) }\end{array}$ & 1 & $\mathrm{~J}$ & $\begin{array}{c}\text { Reasons against comprehensive } \\
\text { exams }\end{array}$ & $\mathrm{N}$ & 2 & 8 & $\begin{array}{l}\text { Attitude towards } \\
\text { senior } \\
\text { comprehensive } \\
\text { exams }\end{array}$ & $\mathrm{N}$ & $\mathrm{r}=.25, \mathrm{~N}=57$ & $\begin{aligned} \mathrm{r}= & -.26, \mathrm{~N} \\
& =57\end{aligned}$ \\
\hline $\begin{array}{l}\text { Tormala, Petty, \& } \\
\text { Brinol (2002) }\end{array}$ & 2 & $\mathrm{~J}$ & $\begin{array}{l}\text { Positive thoughts about } \\
\text { comprehensive exams }\end{array}$ & $\mathrm{N}$ & 2 & 8 & $\begin{array}{l}\text { Attitude towards } \\
\text { senior } \\
\text { comprehensive } \\
\text { exams }\end{array}$ & $\mathrm{N}$ & $\mathrm{r}=.25, \mathrm{~N}=60.5$ & $\begin{aligned} \mathrm{r} & =-.20, \mathrm{~N} \\
& =60.5\end{aligned}$ \\
\hline $\begin{array}{l}\text { Tormala, Petty, \& } \\
\text { Brinol }(2002)^{*}\end{array}$ & 3 & $\mathrm{~J}$ & $\begin{array}{l}\text { Positive thoughts about } \\
\text { comprehensive exams }\end{array}$ & A & 2 & 10 & $\begin{array}{l}\text { Attitude towards } \\
\text { senior } \\
\text { comprehensive } \\
\text { exams }\end{array}$ & $\mathrm{N}$ & - & - \\
\hline $\begin{array}{l}\text { Tormala, Falces, } \\
\text { Brinol, \& Petty }\end{array}$ & 1 & $\mathrm{~J}$ & $\begin{array}{l}\text { Positive thoughts about } \\
\text { comprehensive exams }\end{array}$ & $\mathrm{N}$ & 2 & 10 & $\begin{array}{l}\text { Attitude towards } \\
\text { comprehensive } \\
\text { exams }\end{array}$ & $\mathrm{N}$ & $\mathrm{r}=.44, \mathrm{~N}=28$ & - \\
\hline $\begin{array}{l}\text { Tormala, Falces, } \\
\text { Brinol, \& Petty }\end{array}$ & 2 & $\mathrm{~J}$ & $\begin{array}{l}\text { Negative thoughts about } \\
\text { comprehensive exams }\end{array}$ & $\mathrm{N}$ & 2 & 10 & $\begin{array}{l}\text { Attitude towards } \\
\text { comprehensive } \\
\text { exams }\end{array}$ & $\mathrm{N}$ & $\mathrm{r}=.34, \mathrm{~N}=38$ & - \\
\hline $\begin{array}{l}\text { Tormala, Falces, } \\
\text { Brinol, \& Petty }\end{array}$ & 3 & $\mathrm{~J}$ & Assertiveness & A & 2 & 10 & $\begin{array}{l}\text { Self-rated } \\
\text { Assertiveness }\end{array}$ & $\mathrm{N}$ & $\mathrm{r}=.23, \mathrm{~N}=74$ & - \\
\hline $\begin{array}{l}\text { Tormala, Falces, } \\
\text { Brinol, \& Petty }\end{array}$ & 4 & $\mathrm{~J}$ & $\begin{array}{l}\text { Positive thoughts about } \\
\text { comprehensive exams }\end{array}$ & $\mathrm{N}$ & 2 & 10 & $\begin{array}{l}\text { Attitude towards } \\
\text { comprehensive } \\
\text { exams; } \\
\text { confidence }\end{array}$ & $\mathrm{N}$ & $\mathrm{r}=.34, \mathrm{~N}=43$ & - \\
\hline Tsai \& McGill (2011) & 1 & $\mathrm{~J}$ & $\begin{array}{c}\text { Reasons for preferring one camera } \\
\text { over another for }(\mathrm{C} 1) \text { low or }(\mathrm{C} 2) \\
\text { high construal }\end{array}$ & A & 2 & 10 & $\begin{array}{l}\text { Choice } \\
\text { confidence }\end{array}$ & $\mathrm{N}$ & $\begin{array}{l}\mathrm{C} 1: \mathrm{r}=.42 \mathrm{~N}= \\
44.5, \mathrm{C} 2: \mathrm{r}=.25 \\
\quad \mathrm{~N}=44.5\end{array}$ & - \\
\hline Tsai \& McGill (2011) & 3 & $\mathrm{~J}$ & $\begin{array}{l}\text { Reasons for preferring one movie } \\
\text { over another; }(\mathrm{C} 1, \mathrm{C} 3) \text { low or }(\mathrm{C} 2 \text {, } \\
\mathrm{C} 4) \text { high construal with }(\mathrm{C} 1, \mathrm{C} 2) \text { no } \\
\text { attribution or }(\mathrm{C} 3, \mathrm{C} 4) \text { attribution }\end{array}$ & A & 2 & 8 & $\begin{array}{l}\text { Choice } \\
\text { confidence }\end{array}$ & $\mathrm{C} 3 / \mathrm{C} 4$ & $\begin{array}{l}\mathrm{C} 1: \mathrm{r}=.34 \mathrm{~N}= \\
29.5, \mathrm{C} 2: \mathrm{r}=.37 \\
\quad \mathrm{~N}=29.5\end{array}$ & $\begin{array}{c}\mathrm{C} 3: \mathrm{r}=- \\
.09 \mathrm{~N}= \\
32.5, \mathrm{C} 4: \mathrm{r} \\
=0 \mathrm{~N}= \\
32.5\end{array}$ \\
\hline $\begin{array}{l}\text { Tsai \& Thomas } \\
\text { (2011) }\end{array}$ & 2 & $\mathrm{~J}$ & $\begin{array}{l}\text { Reasons for donating in support of } \\
\text { polar bears; }(\mathrm{C} 1) \text { abstract or }(\mathrm{C} 2) \\
\text { concrete }\end{array}$ & A & 2 & 8 & $\begin{array}{c}\text { Donation } \\
\text { amount }\end{array}$ & $\mathrm{N}$ & & \\
\hline Tybout et al. (2005) & 1 & $\mathrm{~J}$ & Reasons to drive a Hyundai/BMW & A & 1 & 10 & $\begin{array}{l}\text { Product } \\
\text { evaluation }\end{array}$ & $\mathrm{N}$ & $\mathrm{r}=.32, \mathrm{~N}=49.5$ & $\begin{aligned} \mathrm{r} & =-.29, \mathrm{~N} \\
& =49.5\end{aligned}$ \\
\hline Tybout et al. (2005) & 2 & $\mathrm{~J}$ & $\begin{array}{c}\text { Reasons to drive a (C3) Saab/(C1) } \\
\text { Hyundai/ (C2) BMW }\end{array}$ & A & 1 & 10 & $\begin{array}{l}\text { Product } \\
\text { evaluation }\end{array}$ & $\mathrm{N}$ & $\begin{aligned} \mathrm{C} 1: \mathrm{r}=.30, \mathrm{~N}= \\
\\
\quad 34.3 \\
\mathrm{C} 2: \mathrm{r}=.40, \mathrm{~N}= \\
\quad 34.3\end{aligned}$ & $\begin{array}{l}\mathrm{C} 3: \mathrm{r}=- \\
46, \mathrm{~N}= \\
34.3\end{array}$ \\
\hline
\end{tabular}




\begin{tabular}{|c|c|c|c|c|c|c|c|c|c|c|}
\hline Tybout et al. (2005) & 4 & $\mathrm{~J}$ & Reasons to drive a BMW & $\mathrm{N}$ & 1 & 10 & $\begin{array}{l}\text { Product } \\
\text { evaluation }\end{array}$ & $\mathrm{N}$ & $\mathrm{r}=.15, \mathrm{~N}=20.5$ & $\begin{aligned} r & =-.05, \mathrm{~N} \\
& =20.5\end{aligned}$ \\
\hline $\begin{array}{l}\text { Unkelbach \& } \\
\text { Plessner (2007) }\end{array}$ & 2 & $\mathrm{~J}$ & $\begin{array}{c}\text { Reasons }(\mathrm{C} 1) \text { for/ }(\mathrm{C} 2) \text { against } \\
\text { sports-stadium }\end{array}$ & A & 2 & 6 & Preference & $\mathrm{N}$ & $\begin{array}{c}\mathrm{C} 1: \mathrm{r}=.19 \mathrm{~N}= \\
30, \mathrm{C} 2: \mathrm{r}=.38 \mathrm{~N} \\
=27\end{array}$ & - \\
\hline $\begin{array}{l}\text { Vastfjall, Peters, \& } \\
\text { Slovic (2008) }\end{array}$ & 2 & $\mathrm{~J}$ & $\begin{array}{l}\text { Major natural disasters that occurred } \\
\text { in world in last } 100 \text { years }\end{array}$ & $\mathrm{N}$ & 2 & 6 & Risk perception & $\mathrm{N}$ & $\mathrm{r}=.45, \mathrm{~N}=89$ & - \\
\hline Vaughn (1998) & 1 & $\mathrm{D}$ & Assertive/Unassertive & A & 3 & 8 & $\begin{array}{l}\text { Self-rated } \\
\text { Assertiveness }\end{array}$ & $\mathrm{N}$ & $\begin{aligned} \mathrm{r} & =.28, \mathrm{~N}=40 ; \mathrm{r} \\
& =-.20, \mathrm{~N}=40\end{aligned}$ & $\begin{array}{l}\mathrm{r}=.35, \mathrm{~N} \\
=40 ; \mathrm{r}= \\
0, \mathrm{~N}=40\end{array}$ \\
\hline Vaughn (1998) & 2 & $\mathrm{D}$ & Positive things seen in Detroit & A & 3 & 7 & $\begin{array}{l}\text { Desire to live in } \\
\text { Detroit }\end{array}$ & $\mathrm{N}$ & $\mathrm{r}=.06, \mathrm{~N}=55$ & $\begin{aligned} \mathrm{r} & =-.49, \mathrm{~N} \\
& =50\end{aligned}$ \\
\hline Vaughn (1998) & 3 & $\mathrm{D}$ & Positive things seen in Detroit & A & 3 & 9 & $\begin{array}{l}\text { Evaluation of } \\
\text { Detroit }\end{array}$ & $\mathrm{N}$ & $\mathrm{r}=-.36, \mathrm{~N}=29$ & $\begin{aligned} \mathrm{R} & =.24, \mathrm{~N} \\
& =30\end{aligned}$ \\
\hline Vaughn (1999) & 1 & $\mathrm{~J}$ & $\begin{array}{l}\text { Things that you doing to improve } \\
\text { chances of getting good grades on } \\
\text { finals: (C1) hard + start, (C2) hard + } \\
\text { end, (C3) easy }+ \text { end, (C4) easy + } \\
\text { start }\end{array}$ & A & 3 & 8 & Self-efficacy & $\mathrm{N}$ & $\begin{array}{c}\mathrm{C} 1: \mathrm{r}=.25, \mathrm{~N}= \\
43.75\end{array}$ & $\begin{array}{c}\mathrm{C} 2: \mathrm{r}=- \\
.01, \mathrm{~N}= \\
43.75, \mathrm{C} 3: \\
\mathrm{r}=.08, \mathrm{~N} \\
=43.75, \\
\mathrm{C} 4: \mathrm{r}=- \\
.07,43.75\end{array}$ \\
\hline $\begin{array}{l}\text { Vaughn \& Weary } \\
\qquad(2002)\end{array}$ & 1 & $\mathrm{~J}$ & $\begin{array}{l}\text { Reasons event would happen to } \\
\text { them, personally; }(\mathrm{C} 1) \text { no dysphoria } \\
\text { or }(\mathrm{C} 2) \text { dysphoria }\end{array}$ & $\mathrm{A}$ & 2 & 5 & $\begin{array}{l}\text { Likelihood } \\
\text { judgment }\end{array}$ & $\mathrm{N}$ & $\begin{array}{c}\mathrm{C} 1: \mathrm{r}=.11 \mathrm{~N}= \\
45, \mathrm{C} 2: \mathrm{r}=-.04 \mathrm{~N} \\
\quad=50\end{array}$ & - \\
\hline $\begin{array}{l}\text { Von Helversen et al. } \\
\text { (2008) }\end{array}$ & 1 & $\mathrm{~J}$ & Arguments in favor of public transit & A & 4 & 12 & $\begin{array}{l}\text { Attitude about } \\
\text { public transport }\end{array}$ & $\mathrm{N}$ & $\mathrm{r}=.46, \mathrm{~N}=20$ & - \\
\hline $\begin{array}{l}\text { Von Helversen et al. } \\
\qquad(2008)\end{array}$ & 2 & $\mathrm{~J}$ & (C1) Assertive/ (C2) Unassertive & A & 4 & 11 & Assertiveness & $\mathrm{N}$ & $\begin{array}{c}\mathrm{C} 1: \mathrm{r}=.40 \mathrm{~N}= \\
24, \mathrm{C} 2: \mathrm{r}=.28 \mathrm{~N} \\
=24\end{array}$ & - \\
\hline $\begin{array}{l}\text { Walton \& Cohen } \\
\qquad(2007)^{*}\end{array}$ & 1 & $\mathrm{~J}$ & $\begin{array}{c}\text { Friends who had personal } \\
\text { characteristics that would make } \\
\text { them likely to fit in at the school's } \\
\text { CS department }\end{array}$ & A & 2 & 8 & $\begin{array}{l}\text { Sense could fit } \\
\text { in and succeed }\end{array}$ & $\mathrm{N}$ & - & - \\
\hline $\begin{array}{l}\text { Walton \& Cohen } \\
\qquad(2007)^{*}\end{array}$ & $\mathrm{~F}$ & $\mathrm{~J}$ & Skills in domain & A & 2 & 8 & $\begin{array}{l}\text { Sense could fit } \\
\text { in and succeed }\end{array}$ & $\mathrm{N}$ & - & - \\
\hline $\begin{array}{l}\text { Walton \& Cohen } \\
\qquad(2007)^{*}\end{array}$ & $\mathrm{P}$ & $\mathrm{J}$ & $\begin{array}{c}\text { Friends who had personal } \\
\text { characteristics that would make } \\
\text { them likely to fit in at the school's } \\
\text { CS department }\end{array}$ & A & 2 & 8 & $\begin{array}{l}\text { Sense could fit } \\
\text { in and succeed }\end{array}$ & $\mathrm{N}$ & - & - \\
\hline $\begin{array}{l}\text { Wänke, Bless, \& } \\
\text { Biller (1996) }\end{array}$ & 1 & $\mathrm{~J}$ & $\begin{array}{c}\text { Reasons }(\mathrm{C} 1) \text { for/ }(\mathrm{C} 2) \text { against } \\
\text { public transit }\end{array}$ & A & 3 & 7 & $\begin{array}{l}\text { Confidence; } \\
\text { attitude towards } \\
\text { using public } \\
\text { transporation }\end{array}$ & $\mathrm{N}$ & $\begin{array}{c}\mathrm{C} 1: \mathrm{r}=.35 \mathrm{~N}= \\
35, \mathrm{C} 2: \mathrm{r}=.12 \mathrm{~N} \\
\quad=32\end{array}$ & - \\
\hline
\end{tabular}




\begin{tabular}{|c|c|c|}
\hline $\begin{array}{l}\text { Wänke, Bohner, \& } \\
\text { Jurkowitsch (1997) }\end{array}$ & 1 & $\mathrm{~J}$ \\
\hline $\begin{array}{l}\text { Weaver, Vandello, \& } \\
\text { Bosson (2013) }\end{array}$ & 2 & $\mathrm{~J}$ \\
\hline Wehr (2010)* & 1 & $\mathrm{~J}$ \\
\hline Wehr (2010) & 2 & $\mathrm{~J}$ \\
\hline $\begin{array}{l}\text { Weick \& Guinote } \\
\text { (2008) }\end{array}$ & $1 \mathrm{a}$ & $\mathrm{J}$ \\
\hline Weick \& Guinote & 2 & $\mathrm{~J}$ \\
\hline $\begin{array}{l}\text { Weick \& Guinote } \\
\text { (2008) }\end{array}$ & 3 & $\mathrm{~J}$ \\
\hline $\begin{array}{l}\text { Weick \& Guinote } \\
\text { (2008) }\end{array}$ & 4 & $\mathrm{~J}$ \\
\hline $\begin{array}{c}\text { Winkielman, } \\
\text { Schwarz, \& Belli } \\
(1998)\end{array}$ & 1 & $\mathrm{~J}$ \\
\hline $\begin{array}{l}\text { Winkielman \& } \\
\text { Schwarz (2001) }\end{array}$ & 1 & $\mathrm{~J}$ \\
\hline $\begin{array}{l}\text { Woltin, Corneille, \& } \\
\text { Yzerbyt (2014) }\end{array}$ & 1 & $\mathrm{~J}$ \\
\hline $\begin{array}{l}\text { Woltin, Corneille, \& } \\
\text { Yzerbyt (2014) }\end{array}$ & 2 & $\mathrm{~J}$ \\
\hline $\begin{array}{l}\text { Woltin, Corneille, \& } \\
\text { Yzerbyt (2014) }\end{array}$ & 3 & $\mathrm{~J}$ \\
\hline
\end{tabular}
Reasons to (C1, C3) drive/ (C2, C4) not to drive $\mathrm{BMW}$ with $(\mathrm{C} 1, \mathrm{C} 2)$ actual or $(\mathrm{C} 3, \mathrm{C} 4)$ anticipated

$$
\text { experience }
$$

Specific behaviors meeting cultural ideals for real man

Autobiographical situations which were typical problem episodes or exceptions

Autobiographical situations which were typical problem episodes or exceptions

Arguments in favor of sending humans to Mars

\section{Leisure events}

Attributes on which men and

$$
\text { women differ }
$$

\section{Arguments in favor of new} identification card

Events experienced when 5-7 or 8-

$$
10 \text { years old }
$$

Events experienced when 5-7 or 8-

$$
10 \text { years old; }(\mathrm{C} 1) \text { pleasant }
$$

childhood difficult to remember /

(C2) unpleasant childhood difficult

$$
\text { to remember }
$$

$$
\text { Assertive }
$$

Creative

Creative
A, N

\section{BMW}

Evaluation;

Mercedes

Evaluation;

Direct

preference

Masculinity;

private $(\mathrm{C} 1)$

versus public

(C2)

\section{Social Skill}

\section{Coping}

confidence,

serious

Attitude towards

sending humans

to Mars

Leisure time

satisfaction

Stereotypicality;

percentage

estimate

Attitude toward

new

identification

card

Judged

childhood

memory

Childhood

pleasantness

Self-rated

Assertivenes

Self-rated

Creativity

Self-rated

Creativity
$\mathrm{N}$

$\mathrm{C} 1: \mathrm{r}=.28 \mathrm{~N}=$

$38, \mathrm{C} 2: \mathrm{r}=.47 \mathrm{~N}$ $=25, \mathrm{C} 3: \mathrm{r}=.45$

$\mathrm{N}=42, \mathrm{C} 4: \mathrm{r}=$

$.44 \mathrm{~N}=55$

$\mathrm{C} 1: \mathrm{r}=.34, \mathrm{~N}=$

$38 \mathrm{C} 2 \mathrm{:} \mathrm{r}=.13, \mathrm{~N}$

$$
=35
$$

$$
\begin{aligned}
\mathrm{r} & =.18 \mathrm{~N}=46, \mathrm{r} \\
& =.14 \mathrm{~N}=46
\end{aligned}
$$$$
\mathrm{r}=.39, \mathrm{~N}=68
$$$$
\mathrm{r}=.09, \mathrm{~N}
$$$$
=68
$$

$\mathrm{N}$

$$
\mathrm{r}=.30, \mathrm{~N}=41.5 \quad \mathrm{r}=-.28, \mathrm{~N}
$$$$
=41.5
$$$$
\mathrm{r}=.24, \mathrm{~N}=66
$$$$
\mathrm{r}=-.21, \mathrm{~N}
$$$$
=66
$$

$\mathrm{r}=.10, \mathrm{~N}=64$

$$
\begin{aligned}
r & =-.10, \mathrm{~N} \\
& =64
\end{aligned}
$$

$$
\mathrm{r}=.34, \mathrm{~N}=48
$$

(C1) $\mathrm{r}=.19 \mathrm{~N}=$ $179,(\mathrm{C} 2) \mathrm{r}=.03$

$$
\mathrm{N}=179
$$

\section{$\mathrm{N}$}

$$
\mathrm{r}=.32, \mathrm{~N}=74
$$

$$
\mathrm{C} 1: \mathrm{r}=.35, \mathrm{~N}=
$$$$
44
$$ 


\begin{tabular}{|c|c|c|c|c|c|c|c|}
\hline $\begin{array}{l}\text { Woltin, Corneille, \& } \\
\text { Yzerbyt (2014) }\end{array}$ & 4 & $\mathrm{~J}$ & Assertive & A & 2 & 8 & $\begin{array}{c}\text { Self-rated } \\
\text { Assertiveness }\end{array}$ \\
\hline $\begin{array}{l}\text { Woltin, Corneille, \& } \\
\text { Yzerbyt (2014) }\end{array}$ & 5 & $\mathrm{U}$ & Extraversion/lack of extraversion & A & 2 & 5 & $\begin{array}{l}\text { Self-rated } \\
\text { Extroversion }\end{array}$ \\
\hline $\begin{array}{l}\text { Woltin, Corneille, \& } \\
\text { Yzerbyt (2014) }\end{array}$ & 6 & $\mathrm{U}$ & Creative & A & 2 & 6 & $\begin{array}{l}\text { Self-rated } \\
\text { Creativity }\end{array}$ \\
\hline Wood (2010) & 5 & $\mathrm{~J}$ & $\begin{array}{c}\text { Big changes going on in life right } \\
\text { now }\end{array}$ & $\mathrm{N}$ & 2 & 8 & Choice of snack \\
\hline $\begin{array}{l}\text { Yahalom \& Schul } \\
\text { (2013) }\end{array}$ & 1 & $\mathrm{~J}$ & Assertive & $\mathrm{N}$ & 4 & 10 & $\begin{array}{c}\text { Self-rated } \\
\text { Assertiveness }\end{array}$ \\
\hline $\begin{array}{l}\text { Yahalom \& Schul } \\
\qquad(2013)\end{array}$ & 2 & $\mathrm{~J}$ & Assertive & A & 4 & 10 & $\begin{array}{c}\text { Self-rated } \\
\text { Assertiveness }\end{array}$ \\
\hline $\begin{array}{l}\text { Yahalom \& Schul } \\
\text { (2013) }\end{array}$ & 3 & $\mathrm{~J}$ & Assertive & A & 4 & 10 & $\begin{array}{c}\text { Self-rated } \\
\text { Assertiveness }\end{array}$ \\
\hline $\begin{array}{l}\text { Yeager \& Krosnick } \\
\qquad(2002)\end{array}$ & 1 & $\mathrm{U}$ & (C1) Assertive/ (C2) Unassertive & A & 6 & 12 & $\begin{array}{c}\text { Self-rated } \\
\text { Assertiveness }\end{array}$ \\
\hline $\begin{array}{l}\text { Yeager \& Krosnick } \\
\qquad(2010)\end{array}$ & 2 & $\mathrm{U}$ & (C1) Assertive/ (C2) Unassertive & A & 3 & 12 & $\begin{array}{c}\text { Self-rated } \\
\text { Assertiveness }\end{array}$ \\
\hline $\begin{array}{l}\text { Yeager \& Krosnick } \\
\qquad(2012)\end{array}$ & 3 & $\mathrm{U}$ & (C1) Assertive/ (C2) Unassertive & A & 3 & 12 & $\begin{array}{c}\text { Self-rated } \\
\text { Assertiveness }\end{array}$ \\
\hline $\begin{array}{l}\text { Yeager \& Krosnick } \\
\qquad(2012)\end{array}$ & 4 & $\mathrm{U}$ & $\begin{array}{c}(\mathrm{C} 1, \mathrm{C} 3) \text { Assertive/ }(\mathrm{C} 2, \mathrm{C} 4) \\
\text { Unassertive }\end{array}$ & $\begin{array}{c}(\mathrm{C} 1, \mathrm{C} 2) \\
\mathrm{B},(\mathrm{C} 3 \\
\mathrm{C} 4) \mathrm{A}\end{array}$ & 3 & 12 & $\begin{array}{c}\text { Self-rated } \\
\text { Assertiveness }\end{array}$ \\
\hline $\begin{array}{l}\text { Yeager \& Krosnick } \\
\qquad(2013)\end{array}$ & 5 & $\mathrm{U}$ & $\begin{array}{c}\text { (C1, C3) Assertive/ }(\mathrm{C} 2, \mathrm{C} 4) \\
\text { Unassertive }\end{array}$ & $\begin{array}{c}(\mathrm{C} 1, \mathrm{C} 2) \\
\mathrm{B},(\mathrm{C} 3 \\
\mathrm{C} 4) \mathrm{A}\end{array}$ & 3 & 12 & $\begin{array}{c}\text { Self-rated } \\
\text { Assertiveness }\end{array}$ \\
\hline $\begin{array}{l}\text { Yeager \& Krosnick } \\
\qquad(2013)\end{array}$ & 6 & $\mathrm{U}$ & (C1) Assertive/ (C2) Unassertive & A & 3 & 12 & $\begin{array}{c}\text { Self-rated } \\
\text { Assertiveness }\end{array}$ \\
\hline Yoke (2009) & 2 & $\mathrm{D}$ & $\begin{array}{l}\text { Well-known successful same-sex } \\
\text { role models }\end{array}$ & A & 6 & 12 & Math interest \\
\hline $\begin{array}{l}\text { Zhao, Hoeffler, \& } \\
\text { Dahl (2012) }\end{array}$ & 2 & $\mathrm{~J}$ & Activities could do with X1-100 & A & 1 & 8 & $\begin{array}{l}\text { Product } \\
\text { Evaluation }\end{array}$ \\
\hline $\begin{array}{l}\text { Zhao, Hoeffler, \& } \\
\text { Dahl (2012) }\end{array}$ & 3 & $\mathrm{~J}$ & Activities could do with X1-100 & A & 1 & 8 & $\begin{array}{l}\text { Product } \\
\text { Evaluation }\end{array}$ \\
\hline $\begin{array}{l}\text { Zhao, Hoeffler, \& } \\
\text { Dahl (2012) }\end{array}$ & 4 & $\mathrm{~J}$ & Activities could do with Z-500 & A & 1 & 8 & $\begin{array}{l}\text { product } \\
\text { evaluation }\end{array}$ \\
\hline
\end{tabular}

\begin{tabular}{|c|c|}
\hline $\mathrm{r}=.17, \mathrm{~N}=59$ & $\begin{aligned} r= & -.19, \mathrm{~N} \\
& =62\end{aligned}$ \\
\hline $\mathrm{r}=.38, \mathrm{~N}=63$ & $\begin{aligned} r & =-.04, N \\
& =63\end{aligned}$ \\
\hline $\mathrm{r}=-.09, \mathrm{~N}=75.5$ & $\begin{aligned} \mathrm{r} & =-.10, \mathrm{~N} \\
& =75.5\end{aligned}$ \\
\hline $\mathrm{r}=.15, \mathrm{~N}=240$ & - \\
\hline $\mathrm{r}=.27, \mathrm{~N}=43.3$ & $\begin{aligned} \mathrm{r} & =-.29, \mathrm{~N} \\
& =43.3\end{aligned}$ \\
\hline $\mathrm{r}=.40, \mathrm{~N}=40$ & $\begin{array}{c}\mathrm{r}=.02, \mathrm{~N} \\
=40\end{array}$ \\
\hline $\mathrm{r}=.36, \mathrm{~N}=59$ & $\begin{aligned} r & =-.17, \mathrm{~N} \\
& =59\end{aligned}$ \\
\hline $\begin{array}{c}\mathrm{C} 1: \mathrm{r}=-.016 \mathrm{~N}= \\
674, \mathrm{C} 2: \mathrm{r}=.07 \\
\mathrm{~N}=623\end{array}$ & - \\
\hline $\begin{array}{c}\mathrm{C} 1: \mathrm{r}=.03 \mathrm{~N}= \\
404, \mathrm{C} 2: \mathrm{r}=.07 \\
\mathrm{~N}=373\end{array}$ & - \\
\hline $\begin{array}{c}\mathrm{C} 1: \mathrm{r}=.04 \mathrm{~N}= \\
1532, \mathrm{C} 2: \mathrm{r}=-.02 \\
\mathrm{~N}=1579\end{array}$ & - \\
\hline $\begin{array}{l}\mathrm{C} 1: \mathrm{r}=.003 \mathrm{~N}= \\
517, \mathrm{C} 2: \mathrm{r}=-.02 \\
\mathrm{~N}=522, \mathrm{C} 3: \mathrm{r}= \\
.04 \mathrm{~N}=526, \mathrm{C} 4: \\
\mathrm{r}=.04 \mathrm{~N}=540\end{array}$ & - \\
\hline $\begin{array}{l}\mathrm{C} 1: \mathrm{r}=.06 \mathrm{~N}= \\
772, \mathrm{C} 2: \mathrm{r}=-.05 \\
\mathrm{~N}=727, \mathrm{C} 3: \mathrm{r}= \\
.10 \mathrm{~N}=817, \mathrm{C} 4: \\
\mathrm{r}=-.05 \mathrm{~N}=776\end{array}$ & - \\
\hline $\begin{array}{c}\mathrm{C} 1: \mathrm{r}=-.01 \mathrm{~N}= \\
108, \mathrm{C} 2: \mathrm{r}=-.04 \\
\mathrm{~N}=110\end{array}$ & - \\
\hline $\mathrm{r}=.19, \mathrm{~N}=79$ & - \\
\hline $\mathrm{r}=.32, \mathrm{~N}=43$ & $\begin{aligned} \mathrm{r} & =-.07, \mathrm{~N} \\
& =41\end{aligned}$ \\
\hline $\mathrm{r}=.28, \mathrm{~N}=55$ & - \\
\hline $\mathrm{r}=.38, \mathrm{~N}=55$ & $\begin{aligned} \mathrm{r} & =-.01, \mathrm{~N} \\
& =58\end{aligned}$ \\
\hline
\end{tabular}


Notes: Positive effect sizes reflect results in line with the predictions of the original ease-of-retrieval result; for example, generating more arguments in favor of a position yields less support in subsequent dependent measures for that position. Negative effect sizes reflect reversals of those predicted effects.

* indicates study was not included in the final analysis due to exclusion due to statistical insufficiency.

${ }^{1} \mathrm{~J}=$ Journal, $\mathrm{D}=$ Dissertation, $\mathrm{U}=$ Unpublished

${ }^{2} \mathrm{~B}=$ Before, $\mathrm{A}=\mathrm{After}, \mathrm{N}=$ None

${ }^{3} \mathrm{~N}=$ None 
Table B2. List of studies using a few-versus-many manipulation in the database - distal effect sizes.

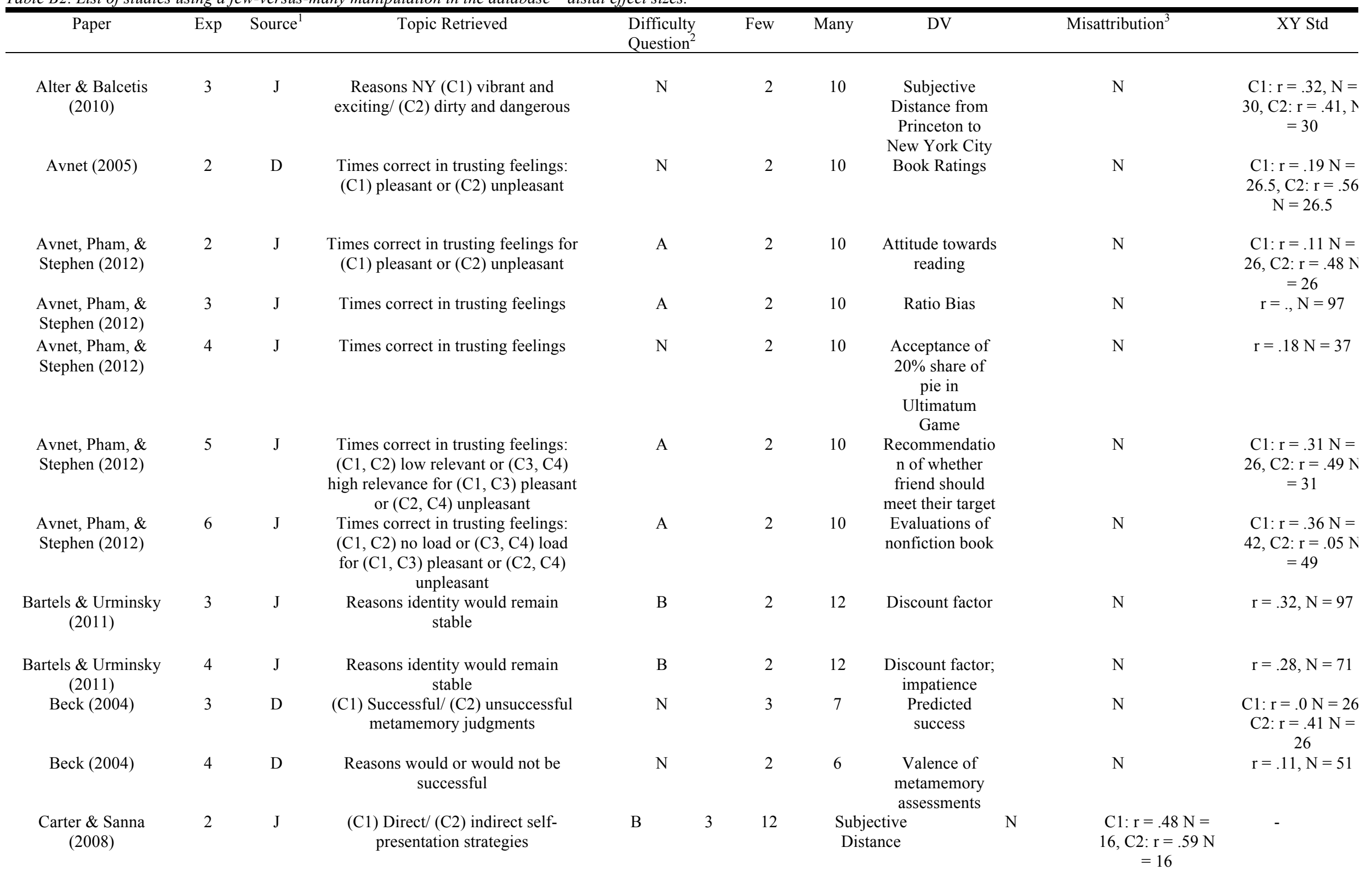




\begin{tabular}{|c|c|c|c|c|c|c|c|c|c|c|}
\hline Caruso et al. (2011) & 1 & $\mathrm{U}$ & Everyday purchases & B & 2 & 6 & $\begin{array}{l}\text { Satisfaction } \\
\text { with personal } \\
\text { finances }\end{array}$ & $\mathrm{N}$ & - & $\begin{aligned} \mathrm{r} & =.09, \mathrm{~N} \\
& =51\end{aligned}$ \\
\hline Cheng (2005) & 3 & $\mathrm{D}$ & $\begin{array}{c}\text { Good things about being an Asian } \\
\text { American }\end{array}$ & $\mathrm{N}$ & 3 & 12 & $\begin{array}{c}\text { Bicultural } \\
\text { Identity } \\
\text { Integration } \\
\text { Scale-Pilot } \\
\text { Version; } \\
\text { Distance Scale; } \\
\text { Conflict scale }\end{array}$ & $\mathrm{N}$ & $\mathrm{r}=.07, \mathrm{~N}=108$ & - \\
\hline Crescioni (2012) & 1 & $\mathrm{D}$ & Stressors & B & 3 & 12 & $\begin{array}{l}\text { Combined } \\
\text { persistence } \\
\text { (attempts and } \\
\text { time spent on } \\
\text { puzzle) }\end{array}$ & $\mathrm{N}$ & $\mathrm{r}=.37, \mathrm{~N}=38$ & - \\
\hline $\begin{array}{l}\text { Cutright, Bettman, \& } \\
\text { Fitzsimons (2013) }\end{array}$ & 1 & $\mathrm{~J}$ & $\begin{array}{l}\text { Things in life over which have } \\
\text { complete control }\end{array}$ & $\mathrm{N}$ & 2 & 10 & $\begin{array}{l}\text { Attitude } \\
\text { favorability } \\
\text { towards brand } \\
\text { extension; } \\
\text { perceived } \\
\text { control }\end{array}$ & $\mathrm{N}$ & $\mathrm{r}=.35, \mathrm{~N}=59$ & - \\
\hline $\begin{array}{l}\text { Cutright, Bettman, \& } \\
\text { Fitzsimons (2013) }\end{array}$ & 3 & $\mathrm{~J}$ & $\begin{array}{l}\text { Things in life over which have } \\
\text { complete control }\end{array}$ & $\mathrm{N}$ & 2 & 10 & $\begin{array}{l}\text { Likelihood of } \\
\text { considering } \\
\text { extension }\end{array}$ & $\mathrm{N}$ & $\mathrm{r}=.53, \mathrm{~N}=46.5$ & $\begin{aligned} \mathrm{r} & =.11, \mathrm{~N} \\
& =46.5\end{aligned}$ \\
\hline Ehrlinger (2004) & 9 & $\mathrm{D}$ & $\begin{array}{c}\text { Reasons might lose money with } \\
\text { investment }\end{array}$ & B & 3 & 12 & Overconfidence & $\mathrm{N}$ & $\mathrm{r}=.33, \mathrm{~N}=33$ & - \\
\hline $\begin{array}{l}\text { Eibach, Libby, \& } \\
\text { Gilovich (2003) }\end{array}$ & 4 & $\mathrm{~J}$ & $\begin{array}{c}\text { Things about you changed since } \\
\text { high school }\end{array}$ & B & 3 & 12 & $\begin{array}{l}\text { External world } \\
\text { change }\end{array}$ & $\mathrm{N}$ & $\mathrm{r}=.25, \mathrm{~N}=80$ & - \\
\hline $\begin{array}{l}\text { Etkin \& Ratner } \\
\text { (2013) }\end{array}$ & 4 & $\mathrm{~J}$ & $\begin{array}{c}(\mathrm{C} 1, \mathrm{C} 2) \text { Similarities/ }(\mathrm{C} 3, \mathrm{C} 4) \\
\text { Differences in protein bars for }(\mathrm{C} 1 \text {, } \\
\mathrm{C} 3) \text { temporally near or }(\mathrm{C} 2, \mathrm{C} 4) \\
\text { temporally far }\end{array}$ & $\mathrm{N}$ & 2 & 10 & $\begin{array}{l}\text { Motivation to } \\
\text { pursue fitness } \\
\text { goal }\end{array}$ & $\mathrm{N}$ & $\begin{array}{c}\mathrm{C} 1: \mathrm{r}=.16 \mathrm{~N}= \\
37.75, \mathrm{C} 2: \mathrm{r}=.17 \\
\mathrm{~N}=37.75, \mathrm{C} 3: \mathrm{r} \\
=.28 \mathrm{~N}=37.75 \\
\mathrm{C} 4: \mathrm{r}=.12 \mathrm{~N}= \\
37.75\end{array}$ & - \\
\hline $\begin{array}{l}\text { Fuller, McIntyre, \& } \\
\text { Oberleitner (2013) }\end{array}$ & 1 & $\mathrm{~J}$ & $\begin{array}{c}\text { Instances of }(\mathrm{C} 1) \text { success/ }(\mathrm{C} 2) \\
\text { failure }\end{array}$ & A & 3 & 9 & $\begin{array}{l}\text { Performance on } \\
\text { trivial pursuit; } \\
\text { comparative } \\
\text { ability } \\
\text { assessment; } \\
\text { performance } \\
\text { perception }\end{array}$ & $\mathrm{N}$ & $\begin{array}{c}\mathrm{C} 1: \mathrm{r}=.40 \mathrm{~N}= \\
20, \mathrm{C} 2: \mathrm{r}=.33 \mathrm{~N} \\
\quad=21\end{array}$ & - \\
\hline Gawronski (2003) & 3 & $\mathrm{~J}$ & $\begin{array}{l}\text { Counterarguments to }(\mathrm{C} 1, \mathrm{C} 2) \text { pro/ } \\
(\mathrm{C} 3, \mathrm{C} 4) \text { con for }(\mathrm{C} 1, \mathrm{C} 3) \text { having } \\
\text { freedom or }(\mathrm{C} 2, \mathrm{C} 4) \text { not }\end{array}$ & $\mathrm{N}$ & 2 & 7 & $\begin{array}{l}\text { Attitude } \\
\text { attribution }\end{array}$ & $\mathrm{N}$ & $\begin{array}{c}\mathrm{C} 1: \mathrm{r}=.11 \mathrm{~N}= \\
19.75, \mathrm{C} 2: \mathrm{r}=.35 \\
\mathrm{~N}=19.75, \mathrm{r}=.35\end{array}$ & - \\
\hline
\end{tabular}




\section{Gawronski \& \\ Bodenhausen (2005)}

Gawronski \&

Bodenhausen (2005)

Gawronski \&

Bodenhausen (2005)

Gawronski \&

Bodenhausen (wp)

Gawronski \&

Bodenhausen (wp)

Gershoff, Mukherjee, $3 \quad$ J

\& Mukhopadhyay

$$
\text { (2008) }
$$

Greifeneder et al.

$$
\text { (2011b) }
$$

Greifeneder et al. $\quad 2 \quad$ J

$$
\text { (2011b) }
$$

Haddock (2004) $2 \quad$ J

$\underset{(2010)}{\text { IJzerman \& Semin }}$

IJzerman \& Semin

$$
\text { (2010) }
$$

IJzerman \& Semin

$$
\text { (2010) }
$$

Janiszewski,

Lichtenstein, \&

Belyavsky (2008)

Keller \& Bless (2005)
(C1) Liked/ (C2) Disliked African

$$
\text { Americans }
$$

Disliked African Americans (C1) response compatibility $(\mathrm{C} 2)$ stimulus compatibility

Women considered strong $(\mathrm{C} 1)$ response compatibility $(\mathrm{C} 2)$ stimulus compatibility

African American individuals whom they particularly disliked Strong women they particularly
disliked

Things liked about movie

Aspects of trust game seeming unfair as senders (C1) low uncertainty (C2) high uncertainty

Aspects of trust game seeming unfair as senders (C1) low uncertainty (C2) high uncertainty Reasons how (C2) personally made event happen/ (C1)other people and external factors made event happen Similarities

\section{Similarities}

\section{Differences}

Bike feature/place to use the bike; (C1) intermediate offer, (C2) premium offer, or (C3) standard offer

(C1) Stereotypic/(C2) nonstereotypic personal experiences

$$
\begin{aligned}
& \mathrm{N}=19.75, \mathrm{r}=.34 \\
& \mathrm{~N}=19.75 \\
& \mathrm{C} 1: \mathrm{r}=.32 \mathrm{~N}= \\
& 18, \mathrm{C} 2 \mathrm{:} \mathrm{r}=.59 \mathrm{~N} \\
& =17 \\
& \mathrm{C} 1 \mathrm{r}=.51 \mathrm{~N}= \\
& 21 \\
& \mathrm{C} 2: \mathrm{r}=- \\
& \mathrm{C} 1 \mathrm{r}=.34 \mathrm{~N}= \\
& 31 \\
& 34 \mathrm{~N}=32 \\
& \mathrm{C} 1: \mathrm{r}=.39, \mathrm{~N}= \\
& 24 \\
& \mathrm{C} 2: \mathrm{r}= \\
& .28, \mathrm{~N}= \\
& \mathrm{C} 1: \mathrm{r}=.41, \mathrm{~N}= \\
& 24 \\
& 30 \\
& 27.5
\end{aligned}
$$$$
\text { prejudice }
$$$$
\text { stereotyping }
$$$$
\text { Implicit }
$$$$
\text { Stereotyping }
$$

Trusting

N

Temporal bias

Ambient

temperature

Ambient

temperature

Ambient

temperature

Transaction

commitment

$\mathrm{C} 1: \mathrm{r}=.27 \mathrm{~N}=$ 43, $\mathrm{C} 2 \mathrm{:} \mathrm{r}=.18 \mathrm{~N}$ 


\begin{tabular}{|c|c|c|c|c|c|c|c|c|c|c|}
\hline Kennedy (2008) & 1 & $\mathrm{D}$ & $\begin{array}{l}\text { Reasons why academic event was } \\
\text { positive/negative in }(\mathrm{C} 1) \text { first or } \\
\text { (C2) } 3^{\text {rd }} \text { person }\end{array}$ & $\mathrm{B}$ & 3 & 12 & $\begin{array}{l}\text { Inevitability } \\
\text { rating } \\
\text { (Hindsight } \\
\text { Judgment) }\end{array}$ & $\mathrm{N}$ & $\begin{array}{c}\mathrm{C} 1: \mathrm{r}=-.12 \mathrm{~N}= \\
52\end{array}$ & $\begin{array}{l}\mathrm{C} 2: \mathrm{r}=- \\
.22 \mathrm{~N}=52\end{array}$ \\
\hline Kennedy (2008) & 2 & $\mathrm{D}$ & $\begin{array}{l}\text { Reasons about why performed in } \\
\text { low percentile }(\mathrm{C} 1) \text { first or }(\mathrm{C} 2) 3^{\text {rd }} \\
\text { person }\end{array}$ & $\mathrm{B}$ & 3 & 12 & $\begin{array}{l}\text { Anticipated, } \\
\text { Expected } \\
\text { (Hindsight } \\
\text { Judgments) }\end{array}$ & $\mathrm{N}$ & $\begin{array}{c}\mathrm{C} 1: \mathrm{r}=.06 \mathrm{~N}= \\
26.5\end{array}$ & $\begin{array}{l}\mathrm{C} 2: \mathrm{r}=- \\
10 \mathrm{~N}= \\
26.5\end{array}$ \\
\hline Lee $(2005)$ & 1 & $\mathrm{~J}$ & Benefits or difficulties of work & A & 2 & 6 & Possible selves & $\mathrm{N}$ & $\mathrm{r}=.30 \mathrm{~N}=79.5$ & - \\
\hline $\begin{array}{c}\text { Lee, Amir, \& Ariely } \\
(2009)\end{array}$ & 3 & $\mathrm{~J}$ & Times correct in trusting feelings & $\mathrm{N}$ & 2 & 10 & $\begin{array}{l}\text { Number of } \\
\text { transitivity } \\
\text { violations }\end{array}$ & $\mathrm{N}$ & $\mathrm{r}=.20, \mathrm{~N}=101$ & $\begin{aligned} \mathrm{r} & =.03, \mathrm{~N} \\
& =101\end{aligned}$ \\
\hline Ling (2009) & 3 & $\mathrm{D}$ & Instances of optimistic thinking & $\mathrm{N}$ & 2 & 8 & $\begin{array}{l}\text { Purchase } \\
\text { decision; } \\
\text { motivation }\end{array}$ & $\mathrm{N}$ & $\mathrm{r}=.27, \mathrm{~N}=76.5$ & $\begin{aligned} \mathrm{r} & =-.15, \mathrm{~N} \\
& =76.5\end{aligned}$ \\
\hline Ling (2009) & 7 & $\mathrm{D}$ & Instances of optimistic thinking & $\mathrm{N}$ & 2 & 8 & $\begin{array}{l}\text { Exercise } \\
\text { intention }\end{array}$ & $\mathrm{N}$ & $\begin{array}{l}\mathrm{r}=.26, \mathrm{~N}= \\
38.75 ; \mathrm{r}=.43, \mathrm{~N} \\
\quad=38.75\end{array}$ & $\begin{array}{l}\mathrm{r}=.18, \mathrm{~N} \\
=38.75 ; \mathrm{r} \\
=-.17, \mathrm{~N} \\
=38.75\end{array}$ \\
\hline Ling (2009) & 8 & $\mathrm{D}$ & Instances of optimistic thinking & $\mathrm{N}$ & 2 & 8 & $\begin{array}{l}\text { Willingness-to- } \\
\text { pay }\end{array}$ & $\mathrm{N}$ & $\begin{array}{l}\mathrm{r}=.10, \mathrm{~N}= \\
48.50 ; \mathrm{r}=.33, \mathrm{~N} \\
\quad=48.50\end{array}$ & $\begin{aligned} \mathrm{r}= & -.29, \mathrm{~N} \\
= & 48.50 ; \mathrm{r} \\
= & .08, \mathrm{~N}= \\
& 48.50\end{aligned}$ \\
\hline Min \& Arkes (2012) & 1 & $\mathrm{~J}$ & Wedding planning steps & A & 2 & 5 & $\begin{array}{l}\text { Optimistic bias } \\
\text { (predicted } \\
\text { minus actual } \\
\text { completion } \\
\text { times); accuracy }\end{array}$ & $\mathrm{N}$ & $\mathrm{r}=.19, \mathrm{~N}=103$ & - \\
\hline Min \& Arkes (2012) & 2 & $\mathrm{~J}$ & $\begin{array}{l}\text { Class assignment planning steps; } \\
\text { (C1) pessimistic or (C2) optimistic }\end{array}$ & A & 2 & 5 & $\begin{array}{l}\text { Optimistic bias } \\
\text { (predicted } \\
\text { minus actual } \\
\text { completion } \\
\text { times); accuracy }\end{array}$ & $\mathrm{N}$ & $\begin{array}{c}\mathrm{C} 1: \mathrm{r}=.17 \mathrm{~N}= \\
36, \mathrm{C} 2: \mathrm{r}=.39 \mathrm{~N} \\
\quad=39\end{array}$ & - \\
\hline Min \& Arkes (2012) & 3 & $\mathrm{~J}$ & $\begin{array}{l}\text { Steps of planning; (C1) ease is bad } \\
\text { or }(\mathrm{C} 2) \text { ease is good }\end{array}$ & A & 2 & 8 & $\begin{array}{l}\text { Optimistic bias } \\
\text { (predicted } \\
\text { minus actual } \\
\text { completion } \\
\text { times); accuracy }\end{array}$ & $\mathrm{N}$ & $\begin{array}{l}\mathrm{C} 1: \mathrm{r}=.26 \mathrm{~N}= \\
60, \mathrm{C} 2: \mathrm{r}=.16 \mathrm{~N} \\
\quad=58\end{array}$ & - \\
\hline Müller et al. (2010) & 1 & $\mathrm{~J}$ & $\begin{array}{c}\text { Unfair aspects of negotiation } \\
\text { procedure }\end{array}$ & B & 2 & 4 & $\begin{array}{l}\text { Cooperative } \\
\text { Behavior }\end{array}$ & $\mathrm{N}$ & $\mathrm{r}=.29, \mathrm{~N}=51$ & $\begin{aligned} \mathrm{r} & =-.31, \mathrm{~N} \\
& =51\end{aligned}$ \\
\hline Ofir et al. (2008) & $1 b$ & $\mathrm{~J}$ & $\begin{array}{c}\text { Number of low-priced products sold } \\
\text { at store }\end{array}$ & A & 2 & 5 & $\begin{array}{c}\text { Store } \\
\text { favorability }\end{array}$ & $\mathrm{N}$ & $\mathrm{r}=.48, \mathrm{~N}=100$ & - \\
\hline Park (2009) & $1 \mathrm{a}$ & $\mathrm{D}$ & $\begin{array}{l}\text { What another person would say } \\
\text { during conversation }\end{array}$ & A & 4 & 15 & $\begin{array}{l}\text { Overall attitude } \\
\text { towards group }\end{array}$ & $\mathrm{N}$ & $r=-.03, N=104$ & - \\
\hline
\end{tabular}




\begin{tabular}{|c|c|c|c|c|c|c|c|c|c|c|}
\hline $\begin{array}{l}\text { Pham, Lee, \& } \\
\text { Stephen (2012) }\end{array}$ & 1 & $\mathrm{~J}$ & Times correct in trusting feelings & $\mathrm{N}$ & 2 & 10 & $\begin{array}{l}\text { Prediction } \\
\text { accuracy }\end{array}$ & $\mathrm{N}$ & $\mathrm{r}=.10, \mathrm{~N}=231$ & - \\
\hline $\begin{array}{l}\text { Pham, Lee, \& } \\
\text { Stephen (2012) }\end{array}$ & 2 & $\mathrm{~J}$ & $\begin{array}{l}\text { Times correct in trusting feelings, } \\
\text { Times searching for info on Google }\end{array}$ & $\mathrm{N}$ & 2 & 10 & $\begin{array}{l}\text { Prediction } \\
\text { accuracy }\end{array}$ & $\mathrm{N}$ & $\mathrm{r}=.27, \mathrm{~N}=85.5$ & $\begin{aligned} \mathrm{r} & =-.03, \mathrm{~N} \\
& =85.5\end{aligned}$ \\
\hline $\begin{array}{l}\text { Pham, Lee, \& } \\
\text { Stephen (2012) }\end{array}$ & 4 & $\mathrm{~J}$ & Times correct in trusting feelings & $\mathrm{N}$ & 2 & 10 & $\begin{array}{l}\text { Prediction } \\
\text { accuracy }\end{array}$ & $\mathrm{N}$ & $\mathrm{r}=.19, \mathrm{~N}=134$ & - \\
\hline $\begin{array}{l}\text { Pham, Lee, \& } \\
\text { Stephen (2012) }\end{array}$ & 5 & $\mathrm{~J}$ & Times correct in trusting feelings & $\mathrm{N}$ & 2 & 10 & $\begin{array}{l}\text { Prediction } \\
\text { accuracy }\end{array}$ & $\mathrm{N}$ & $\mathrm{r}=.11, \mathrm{~N}=204$ & - \\
\hline $\begin{array}{l}\text { Pham, Lee, \& } \\
\text { Stephen (2012) }\end{array}$ & 6 & $\mathrm{~J}$ & Times correct in trusting feelings & $\mathrm{N}$ & 2 & 10 & $\begin{array}{l}\text { Prediction } \\
\text { accuracy }\end{array}$ & $\mathrm{N}$ & $\mathrm{r}=.23, \mathrm{~N}=52$ & - \\
\hline $\begin{array}{l}\text { Pham, Lee, \& } \\
\text { Stephen (2012) }\end{array}$ & 8 & $\mathrm{~J}$ & Times correct in trusting feelings & $\mathrm{N}$ & 2 & 10 & $\begin{array}{l}\text { Prediction } \\
\text { accuracy }\end{array}$ & $\mathrm{N}$ & $\begin{array}{c}r=.37, \mathrm{~N}= \\
116.67\end{array}$ & - \\
\hline $\begin{array}{l}\text { Redden \& Galak } \\
\qquad(2012)\end{array}$ & 2 & $\mathrm{~J}$ & Last times heard favorite song & $\mathrm{N}$ & 2 & 6 & $\begin{array}{l}\text { Choice of } \\
\text { favorite song }\end{array}$ & $\mathrm{N}$ & $\begin{array}{c}\mathrm{r}=.22, \mathrm{~N}= \\
200.67\end{array}$ & - \\
\hline $\begin{array}{l}\text { Sanna, Chang, \& } \\
\text { Carter (2004) }\end{array}$ & 3 & $\mathrm{~J}$ & $\begin{array}{c}\text { Thoughts about }(\mathrm{C} 1) \text { outcome/ }(\mathrm{C} 2) \\
\text { alternative }\end{array}$ & $\mathrm{B}$ & 2 & 10 & $\begin{array}{l}\text { Subjective } \\
\text { temporal } \\
\text { distance }\end{array}$ & $\mathrm{N}$ & $\begin{array}{c}\mathrm{C} 1: \mathrm{r}=.66 \mathrm{~N}= \\
20, \mathrm{C} 2: \mathrm{r}=.69 \mathrm{~N} \\
\quad=20\end{array}$ & - \\
\hline $\begin{array}{l}\text { Sanna, Parks, Chang, } \\
\text { \& Carter (2005) }\end{array}$ & 3 & $\mathrm{~J}$ & $\begin{array}{l}\text { Reasons for }(\mathrm{C} 1) \text { successful/ }(\mathrm{C} 2) \\
\text { unsuccessful task completion }\end{array}$ & B & 5 & 15 & $\begin{array}{c}\text { Subjective } \\
\text { temporal } \\
\text { distance }\end{array}$ & $\mathrm{N}$ & $\begin{array}{l}\mathrm{C} 1: \mathrm{r}=.51 \mathrm{~N}= \\
20, \mathrm{C} 2: \mathrm{r}=.57 \mathrm{~N} \\
\quad=20\end{array}$ & - \\
\hline Sharma et al. (2014) & 2 & $\mathrm{~J}$ & Times worse off financially & $\mathrm{N}$ & 2 & 10 & Dishonesty rate & $\mathrm{N}$ & $\mathrm{r}=.28, \mathrm{~N}=50$ & - \\
\hline Sharma et al. (2014) & $\begin{array}{c}2 \text { pilo } \\
\mathrm{t}\end{array}$ & $\mathrm{J}$ & $\begin{array}{c}\text { Times worse off financially, } \\
\text { Assertive }\end{array}$ & A & 2 & 10 & $\begin{array}{c}\text { Self-rated } \\
\text { Financial well- } \\
\text { being }\end{array}$ & $\mathrm{N}$ & $\mathrm{r}=.32, \mathrm{~N}=88.5$ & $\begin{aligned} \mathrm{r} & =.01, \mathrm{~N} \\
& =88.5\end{aligned}$ \\
\hline Sharma et al. (2014) & 4 & $\mathrm{~J}$ & Times worse off financially & $\mathrm{N}$ & 2 & 10 & $\begin{array}{l}\text { Mean sentence } \\
\text { severity }\end{array}$ & $\mathrm{N}$ & $\mathrm{r}=0, \mathrm{~N}=96$ & - \\
\hline Sharma et al. (2014) & $4 \mathrm{f}$ & $\mathrm{J}$ & Times worse off financially & $\mathrm{N}$ & 2 & 10 & Fairness & $\mathrm{N}$ & $\mathrm{r}=.06, \mathrm{~N}=187$ & - \\
\hline $\begin{array}{l}\text { Stephen \& Pham } \\
\text { (2008) }\end{array}$ & 1 & $\mathrm{~J}$ & Times correct in trusting feelings & $\mathrm{N}$ & 2 & 10 & $\begin{array}{l}\text { Offers in } \\
\text { Ultimatum } \\
\text { Game }\end{array}$ & $\mathrm{N}$ & $\mathrm{r}=.31, \mathrm{~N}=60$ & - \\
\hline $\begin{array}{l}\text { Stephen \& Pham } \\
\text { (2008) }\end{array}$ & 2 & $\mathrm{~J}$ & Times correct in trusting feelings & $\mathrm{N}$ & 2 & 10 & $\begin{array}{l}\text { Initial offers in } \\
\text { counteroffer } \\
\text { game }\end{array}$ & $\mathrm{N}$ & $\mathrm{r}=.27, \mathrm{~N}=47$ & - \\
\hline $\begin{array}{l}\text { Stephen \& Pham } \\
\text { (2008) }\end{array}$ & 3 & $\mathrm{~J}$ & Times correct in trusting feelings & $\mathrm{N}$ & 2 & 10 & $\begin{array}{l}\text { Offer size in } \\
\text { Dictator Game }\end{array}$ & $\mathrm{N}$ & $\mathrm{r}=.36, \mathrm{~N}=58$ & - \\
\hline $\begin{array}{l}\text { Stephen \& Pham } \\
\text { (2008) }\end{array}$ & pilot & $\mathrm{J}$ & Times correct in trusting feelings & $\mathrm{N}$ & 2 & 10 & $\begin{array}{l}\text { Self-rated Trust } \\
\text { in feelings }\end{array}$ & $\mathrm{N}$ & $\mathrm{r}=.36, \mathrm{~N}=36$ & - \\
\hline $\begin{array}{l}\text { Sussman \& Alter } \\
\text { (2012) }\end{array}$ & $4 \mathrm{~b}$ & $\mathrm{~J}$ & Recently purchased items & A & 3 & 10 & $\begin{array}{l}\text { Willingness-to- } \\
\text { pay }\end{array}$ & $\mathrm{N}$ & $\mathrm{r}=.14, \mathrm{~N}=254$ & - \\
\hline
\end{tabular}




\begin{tabular}{|c|c|c|c|c|c|c|c|c|c|c|}
\hline Thorisdottir \& Jost & $1 \mathrm{a}$ & $\mathrm{J}$ & $\begin{array}{l}\text { Instances in which they felt } \\
\text { threatened }\end{array}$ & $\mathrm{N}$ & 3 & 12 & $\begin{array}{l}\text { Self-rated } \\
\text { Closed- } \\
\text { mindedness } \\
\text { (NFC scale) }\end{array}$ & $\mathrm{N}$ & - & $\begin{aligned} \mathrm{r}= & -.04, \mathrm{~N} \\
& =48\end{aligned}$ \\
\hline Thorisdottir \& Jost & $1 b$ & $\mathrm{~J}$ & $\begin{array}{l}\text { Instances in which they felt } \\
\text { threatened }\end{array}$ & $\mathrm{N}$ & 3 & 12 & $\begin{array}{c}\text { Self-rated } \\
\text { Closed- } \\
\text { mindedness; } \\
\text { perceived threat }\end{array}$ & $\mathrm{N}$ & - & $\begin{aligned} \mathrm{r}= & -.33, \mathrm{~N} \\
& =50\end{aligned}$ \\
\hline $\begin{array}{l}\text { Weaver, Vandello, \& } \\
\text { Bosson (2013) }\end{array}$ & 2 & $\mathrm{~J}$ & $\begin{array}{l}\text { Specific behaviors meeting cultural } \\
\text { ideals for real man }\end{array}$ & B & 2 & 10 & $\begin{array}{l}\text { Imminent } \\
\text { payoff choice }\end{array}$ & $\mathrm{N}$ & $\mathrm{r}=.32, \mathrm{~N}=35$ & $\begin{aligned} \mathrm{r} & =.03, \mathrm{~N} \\
& =38\end{aligned}$ \\
\hline Wood (2010) & 5 & $\mathrm{~J}$ & $\begin{array}{c}\text { Big changes going on in life right } \\
\text { now }\end{array}$ & $\mathrm{N}$ & 2 & 8 & Choice of snack & $\mathrm{N}$ & $\mathrm{r}=.15, \mathrm{~N}=240$ & - \\
\hline $\begin{array}{l}\text { Zauberman, Ratner, } \\
\text { \& Kim (2009) }\end{array}$ & 5 & $\mathrm{~J}$ & $\begin{array}{c}\text { (C1) Special/ (C2)non-special } \\
\text { experiences }\end{array}$ & $\mathrm{N}$ & 2 & 10 & $\begin{array}{l}\text { Willingness-to- } \\
\text { pay for } \\
\text { Keychain }\end{array}$ & $\mathrm{N}$ & $\begin{array}{c}\mathrm{C} 1: \mathrm{r}=.16 \mathrm{~N}= \\
112, \mathrm{r}=.10 \mathrm{~N}= \\
112\end{array}$ & - \\
\hline $\begin{array}{l}\text { Zhao, Hoeffler, \& } \\
\text { Dahl (2012) }\end{array}$ & 4 & $\mathrm{~J}$ & Activities could do with Z-500 & A & 1 & 8 & $\begin{array}{l}\text { Choice of } \\
\text { product over } \\
\text { Amazon gift } \\
\text { certificate; } \\
\text { product } \\
\text { evaluation }\end{array}$ & $\mathrm{N}$ & $\mathrm{r}=.33, \mathrm{~N}=55$ & $\begin{aligned} \mathrm{r} & =-.06, \mathrm{~N} \\
& =58\end{aligned}$ \\
\hline
\end{tabular}

Notes: Positive effect sizes reflect results in line with the predictions of the original ease-of-retrieval result; for example, generating more arguments in favor of a position yields less support in subsequent dependent measures for that position. Negative effect sizes reflect reversals of those predicted effects.

* indicates study was not included in the final analysis due to exclusion due to statistical insufficiency.

${ }^{1} \mathrm{~J}=$ Journal, $\mathrm{D}=$ Dissertation, $\mathrm{U}=$ Unpublished

${ }^{2} \mathrm{~B}=$ Before, $\mathrm{A}=\mathrm{After}, \mathrm{N}=$ None

${ }^{3} \mathrm{~N}=$ None 


\section{APPENDIX C: STANDARD PARADIGM MEDIATION MODERATOR ANALYSES}

Table C.1.

Moderator Means and Multiple Regression Results for the Indirect Effect ( $a$ x b) and the Direct Effect (c') Decomposition of the Ease-of-Retrieval Effect for proximal standard paradigm.

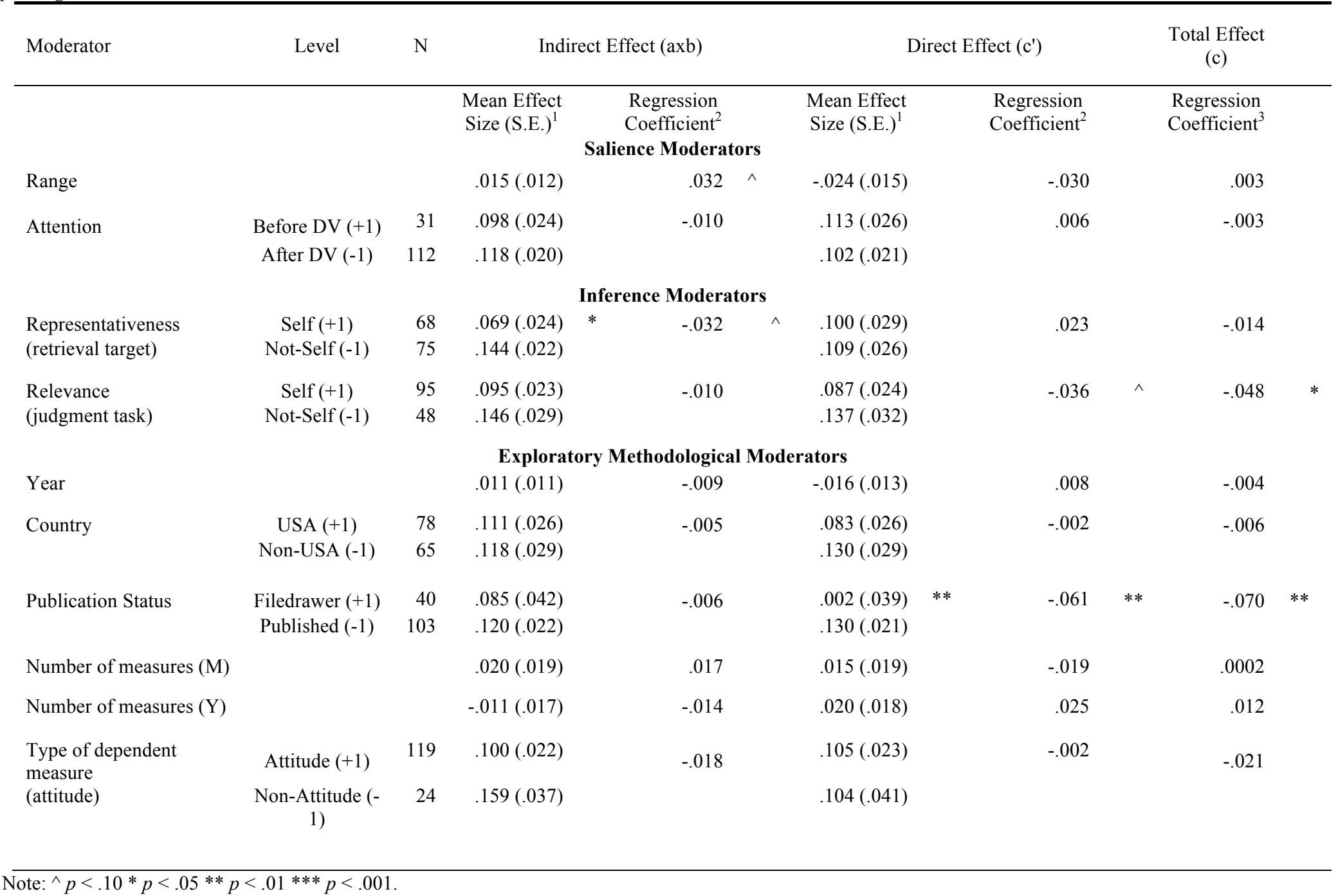


${ }^{1}$ Sample means and standard errors were computed separately for each level, except for continuous variables for which bivariate regression slopes and associated standard errors are reported. Bivariate tests were used to determine statistical significance levels.

${ }^{2}$ Coefficients are based on a multiple regression that used a two-level model with random intercepts for papers. All variables were standardized. VIFs were all below 10 and the maximum condition index was below 30 .

${ }^{3}$ The Total Effect is provided as a benchmark 
Table C.2.

Moderator Means and Multiple Regression Results for the Indirect Effect ( $a \times$ b) and the Direct Effect (c') Decomposition of the Ease-of-Retrieval Effect for distal standard paradigm.

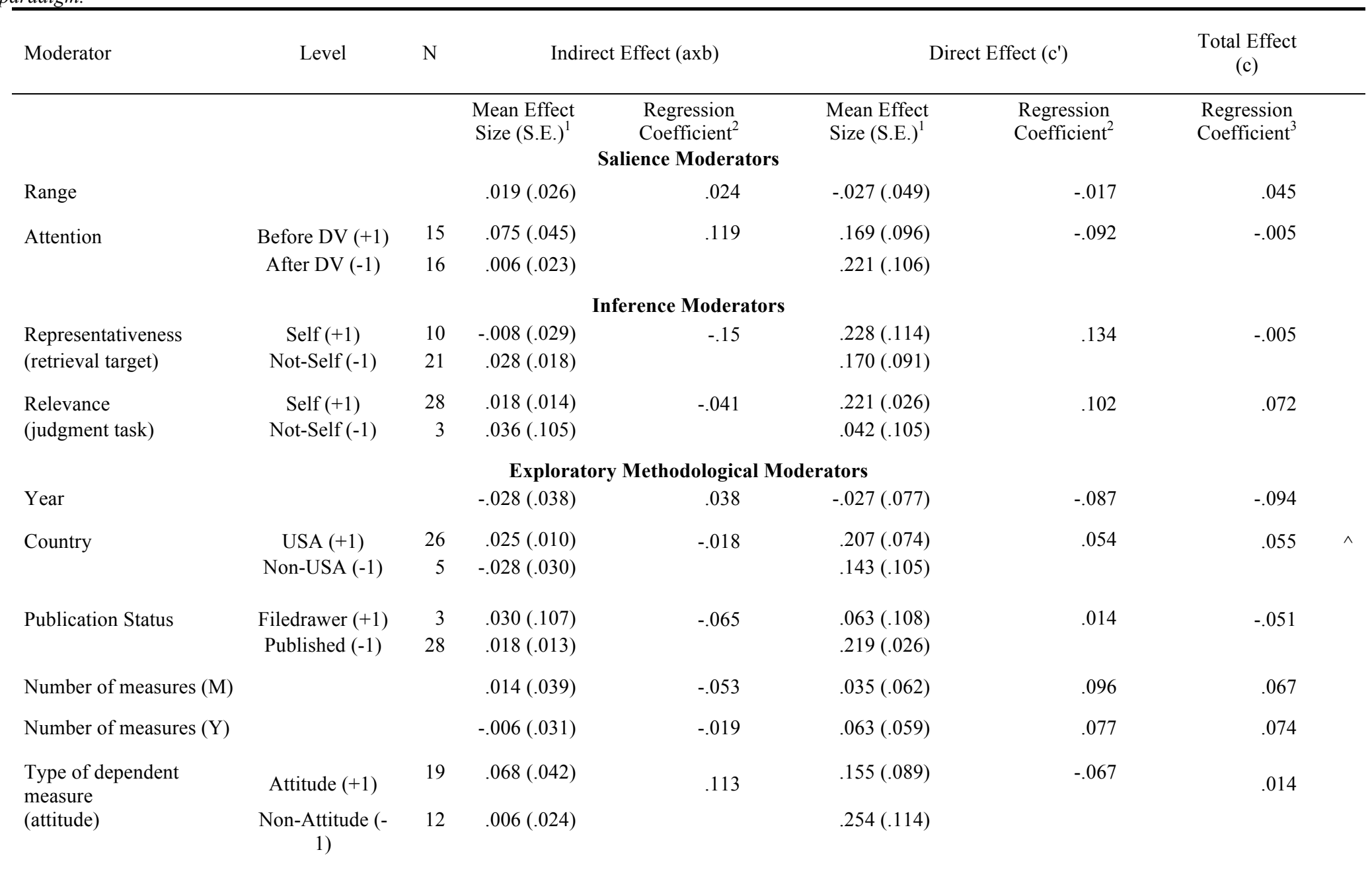

Note: ${ }^{\wedge} p<.10 * p<.05 * * p<.01 * * * p<.001$.

${ }^{1}$ Sample means and standard errors were computed separately for each level, except for continuous variables for which bivariate regression slopes and associated standard errors are reported. Bivariate tests were used to determine statistical significance levels. 
${ }^{2}$ Coefficients are based on a multiple regression that used a two-level model with random intercepts for papers. All variables were standardized. VIFs were all below 10 and the maximum condition index was below 30 .

The Total Effect is provided as a benchmark 


\section{Appendix D \\ Computational Methods for Testing Robustness with respect to Heterogeneity and Potential Bias Due to Measurement Error and Correlated Error}

In this Appendix, we describe the computational method used to estimate bias due to measurement error and correlated error.

Recently, Fritz, Kenny, \& MacKinnon $(2014,2016)$ have detailed the opposing nature of biases due to measurement error and those due to correlated error. Figure 7 extends the simple mediation model depicted in Figure 2 to depict measurement error and correlated error.

Measurement error in $M$ creates a negative bias in the OLS estimate of $b$ and a positive bias in $c^{\prime}$. In contrast, correlated error in $M$ and $Y$ (usually assumed to be due to some unmeasured confounding variable) creates a positive bias in the OLS estimate of $b$ and a negative bias in $c^{\prime}$. Thus, the two biases "cancel" to some degree and the net bias depends on the exact levels of the two sources of bias. This fact alone is somewhat reassuring for those who would like to believe that the OLS estimates are relatively unbiased and close to the true values. However, we take a more precise and comprehensive approach that adjusts the direct and indirect effects for these biases using plausible levels of the two sources of bias for each observation in the triplets dataset for the standard paradigm. This approach uses the results and recommendations of Fritz, Kenny, and MacKinnon (2014, 2016), MacKinnon and Pirlott (2015), and Pearl (2014).

Equations $1-3$ in the text defined the estimates of the traditional OLS mediation model. In this appendix, we subscript them with "U" as follows, to indicate that they are unadjusted.

$$
\begin{gathered}
a_{U}=r_{X M} \\
b_{U}=\left(r_{M Y}-r_{X Y} * r_{X M}\right) /\left(1-r_{X M}{ }^{2}\right) \\
c^{\prime}{ }_{U}=\left(r_{X Y}-r_{M Y} * r_{X M}\right) /\left(1-r_{X M}{ }^{2}\right)
\end{gathered}
$$

The formulae for estimates that are corrected for measurement error and correlated error are as follows. 


$$
a=r_{X M_{T}}=r_{X M}\left(r_{M M}\right)^{5}
$$

where $r_{M M}$ is the reliability of $M$ and is determined by the size of $d$ in Figure 7.

$$
b=\left(b_{U} / \alpha\right)-\pi
$$

and

$$
c^{\prime}=c_{U}^{\prime}-\left(a b_{U}(1-\alpha) / \alpha\right)+a \pi
$$

where

$$
\begin{gathered}
\alpha=\left(r_{M M}-r_{X M}{ }^{2}\right) /\left(1-r_{X M}{ }^{2}\right), \\
\pi=e f /\left[r_{M M}\left(1-r_{X M_{T}}{ }^{2}\right)\right],
\end{gathered}
$$

and the variances of $M$ and $C$ are assumed to be 1 . These formulae and assumptions closely follows Fritz at al. (2014; (D.4) is from their equation (4), (D.5) is from (13), (D.6) is from (14), (D.7) is from (5), and (D.8) is from (12) plus (4) and the assumption that $S_{M}{ }^{2}=S_{C}{ }^{2}=1$ ). Fritz at al. (2016) extended their earlier work by addressing the effects of measurement error in $Y$ (i.e., $r_{Y Y}<1$ ) and by providing explicit formulae for standardized regression coefficients (which we necessarily use because our data are limited to the three correlations). The new formula for $b$ is equivalent to the one described in the text, given the reasonable assumption that $r_{Y Y}=r_{M M}$ (which is set to .8 in our analyses, see below). The new formula for $c^{\prime}$ is equivalent to the one used in the text only when $r_{Y Y}=1$ (which is unlikely). However, for our data, estimates of $c^{\prime}$ based on $r_{Y Y}=1$ and estimates based on $r_{Y Y}=.8$ are essentially the same $(r=.9987$, with means equal to .079 and .084 , respectively). We ignore $r_{Y Y}$ in the text for clarity of exposition, and the fact that its effects are relatively small compared to those of measurement error (i.e., $r_{M M}<1$ ) and correlated error (i.e., $e=f>0$ ).

To adjust the OLS estimates of indirect (a x b) and direct $\left(c^{\prime}\right)$ effects we chose plausible values of error parameters. In particular, we used $r_{M M}=.8$ for measurement error because this is 
the traditional level of minimum reliability used in many research areas. Choosing plausible values for $e$ and $f$ was based on the literature on response style (which is the most natural source of unmeasured confounding variables for ease-or-retrieval experiments). in a large scale study the effects of response style, Baumgartner \& Steenkamp (2001; see also Podsakoff, MacKenzie, \& Podsakoff, 2012) estimate inflation for $r_{M Y}$ to be about 58\%. Assuming $e=f=.34$ yields inflation close to this level. Inflation for $r_{M Y}$ was estimated based on Pearl's (2014) formula for $r_{M Y}=\beta_{M Y}=d\left(b+e f+a c^{\prime}\right)$, which yields inflation equal to $\left[\left(b+e f+a c^{\prime}\right) /\left(b+a c^{\prime}\right)\right]-1$. We also note that this is close to the moderate level of correlated error used by Fritz et al. in their simulations (which were $.19, .39$, and .59 in the 2014 analyses and .32 in the 2016 analyses). This level of correlated error is also consistent with a sensitivity analysis that we conducted for the overall average values of $r_{X Y}, r_{X M}$, and $r_{M Y}$ in our data, a reasonable range of measurement error (i.e., low and high reliability for $M, .6$ and .8 respectively), and a reasonable estimate of correlated error (i.e., $e=f=.19, .34$, and .39 ). The results are provided in Table D.1.

The sensitivity analysis revealed that, for the standard paradigm, the expected bias for correlations near the average values for the standard paradigm is such that $b$ and $a \times b$ are maximally underestimated when reliability and correlated error are low (i.e., $r_{M M}=.6$ and $e=f$ $=.19$ ) and maximally overestimated when reliability and correlated error are high (i.e., $r_{M M}=.8$ and $e=f=.39$ ). For the moderated paradigm, the expected bias for correlations near the average values is such that $c^{\prime}$ (i.e., the presumed causal path when the effect is moderated) is not much affected and is always negative, and $b$ and $a \times b$ are strongly reduced except when correlated error is low (i.e., $e=f=.19$ ). 
Table D.1.

Sensitivity Analysis for estimated mediation coefficients corrected measurement error and correlated error.

\begin{tabular}{|c|c|c|c|c|c|c|c|c|c|c|c|c|c|c|}
\hline \multirow[b]{2}{*}{ Measurement Error (ME) } & \multicolumn{7}{|c|}{ Standard } & \multicolumn{7}{|c|}{ Moderated } \\
\hline & None & Low & Low & Low & High & High & High & None & Low & Low & Low & High & High & High \\
\hline$r_{M M}$ & 1.000 & .800 & .800 & .800 & .600 & .600 & .600 & 1.000 & .800 & .800 & .800 & .600 & .600 & .600 \\
\hline $\begin{array}{l}\text { Correlated Error (CE) } \\
e=f\end{array}$ & $\begin{array}{r}\text { None } \\
.000\end{array}$ & $\begin{array}{l}\text { Low } \\
.190\end{array}$ & $\begin{array}{r}\text { Med. } \\
.340\end{array}$ & $\begin{array}{r}\text { High } \\
.390\end{array}$ & $\begin{array}{l}\text { Low } \\
.190\end{array}$ & $\begin{array}{r}\text { Med. } \\
.340\end{array}$ & $\begin{array}{r}\text { High } \\
.390\end{array}$ & $\begin{array}{r}\text { None } \\
.000\end{array}$ & $\begin{array}{l}\text { Low } \\
.190\end{array}$ & $\begin{array}{r}\text { Med. } \\
.340\end{array}$ & $\begin{array}{r}\text { High } \\
.390\end{array}$ & $\begin{array}{l}\text { Low } \\
.190\end{array}$ & $\begin{array}{r}\text { Med. } \\
.340\end{array}$ & $\begin{array}{r}\text { High } \\
.390\end{array}$ \\
\hline \multicolumn{15}{|c|}{ Raw Correlations and Bias Correction Factors } \\
\hline 1. $r_{X Y}$ & .248 & .248 & .248 & .248 & .248 & .248 & .248 & -.157 & -.157 & -.157 & -.157 & -.157 & -.157 & -.157 \\
\hline 2. $r_{X M}$ & .405 & .405 & .405 & .405 & .405 & .405 & .405 & .288 & .288 & .288 & .288 & .288 & .288 & .288 \\
\hline 3. $r_{M Y}$ & .297 & .297 & .297 & .297 & .297 & .297 & .297 & .058 & .058 & .058 & .058 & .058 & .058 & .058 \\
\hline 4. $r_{X M_{T}}(a)$ & .405 & .453 & .453 & .453 & .523 & .523 & .523 & .288 & .322 & .322 & .322 & .372 & .372 & .372 \\
\hline 5. $\alpha$ & 1.000 & .761 & .761 & .761 & .522 & .522 & .522 & 1.000 & .782 & .782 & .782 & .564 & .564 & .564 \\
\hline 6. $\pi$ (no $\mathrm{ME})$ & .000 & .043 & .138 & .182 & .043 & .138 & .182 & .000 & .039 & .126 & .166 & .039 & .126 & .166 \\
\hline 7. $\pi(\mathrm{w} / \mathrm{ME})$ & .000 & .057 & .182 & .239 & .083 & .265 & .349 & .000 & .050 & .161 & .212 & .070 & .224 & .294 \\
\hline \multicolumn{15}{|c|}{ Estimates of b } \\
\hline 8. $b$ (uncorrected) & .235 & .235 & .235 & .235 & .235 & .235 & .235 & .113 & .113 & .113 & .113 & .113 & .113 & .113 \\
\hline 9. $b$ (corrected, ME only) & .235 & .309 & .309 & .309 & .451 & .451 & .451 & .113 & .144 & .144 & .144 & .200 & .200 & .200 \\
\hline 10. $b$ (corrected, CE only) & .235 & .192 & .097 & .053 & .192 & .097 & .053 & .113 & .073 & -.014 & -.053 & .073 & -.014 & -.053 \\
\hline $11 . b$ (corrected) & .235 & .252 & .127 & .070 & .368 & .186 & .102 & .113 & .094 & -.017 & -.068 & .130 & -.024 & -.095 \\
\hline \multicolumn{15}{|c|}{ Estimates of $a \times b$ (indirect effect) } \\
\hline 12. $a \times b$ (uncorrected) & .095 & .095 & .095 & .095 & .095 & .095 & .095 & .032 & .032 & .032 & .032 & .032 & .032 & .032 \\
\hline 13. $a \times b$ (corrected) & .095 & .093 & .047 & .026 & .145 & .073 & .040 & .032 & .025 & -.005 & -.018 & .037 & -.007 & -.027 \\
\hline \multicolumn{15}{|c|}{ Estimates of $c^{\prime}$ (direct effect) } \\
\hline 14. $c^{\prime}$ (uncorrected) & .153 & .153 & .153 & .153 & .153 & .153 & .153 & -.189 & -.189 & -.189 & -.189 & -.189 & -.189 & -.189 \\
\hline 15. $c^{\prime}($ corrected $)$ & .153 & .160 & .206 & .227 & .122 & .193 & .226 & -.189 & -.180 & -.151 & -.137 & -.188 & -.144 & -.123 \\
\hline \multicolumn{15}{|c|}{ Estimates of bias } \\
\hline 16. Bias in $b$ & .000 & -.017 & .108 & .165 & -.133 & .049 & .133 & .000 & .019 & .130 & .181 & -.017 & .137 & .207 \\
\hline 17. Bias in $a \times b$ & .000 & -.019 & .038 & .064 & -.097 & -.002 & .042 & .000 & .002 & .038 & .054 & -.016 & .041 & .068 \\
\hline 18. Bias in $c^{\prime}$ & .000 & .008 & -.049 & -.075 & .069 & -.026 & -.070 & .000 & -.006 & -.042 & -.058 & .006 & -.051 & -.077 \\
\hline
\end{tabular}

